\title{
E-MOBILITY OPTIONS FOR ADB DEVELOPING MEMBER COUNTRIES
}

Jürg M. Grütter and Ki-Joon Kim

NO. 60

March 2019
ADB SUSTAINABLE DEVELOPMENT WORKING PAPER SERIES 

ADB Sustainable Development Working Paper Series

\section{E-Mobility Options for ADB Developing Member Countries}

Jürg M. Grütter and Ki-Joon Kim

No. 60 | March 2019
Jürg M. Grütter is an independent ADB consultant for this study. Ki-Joon Kim is a Principal Transport Specialist, Transport Sector Group, Sector Advisory Service Cluster of $A D B$. 
(c) 2019 Asian Development Bank

6 ADB Avenue, Mandaluyong City, 1550 Metro Manila, Philippines

Tel +632632 4444; Fax+6326362444

www.adb.org

Some rights reserved. Published in 2019.

Printed in the Philippines.

Publication Stock No. WPS190075-2

DOI: http://dx.doi.org/10.22617/WPS190075-2

The views expressed in this publication are those of the authors and do not necessarily reflect the views and policies of the Asian Development Bank (ADB) or its Board of Governors or the governments they represent.

ADB does not guarantee the accuracy of the data included in this publication and accepts no responsibility for any consequence of their use. The mention of specific companies or products of manufacturers does not imply that they are endorsed or recommended by ADB in preference to others of a similar nature that are not mentioned.

By making any designation of or reference to a particular territory or geographic area, or by using the term "country" in this document, $A D B$ does not intend to make any judgments as to the legal or other status of any territory or area.

This work is available under the Creative Commons Attribution 3.0 IGO license (CC BY 3.0 IGO) https:// creativecommons.org/licenses/by/3.0/igo/. By using the content of this publication, you agree to be bound by the terms of this license. For attribution, translations, adaptations, and permissions, please read the provisions and terms of use at https://www.adb.org/terms-use\#openaccess.

This CC license does not apply to non-ADB copyright materials in this publication. If the material is attributed to another source, please contact the copyright owner or publisher of that source for permission to reproduce it. ADB cannot be held liable for any claims that arise as a result of your use of the material.

Please contact pubsmarketing@adb.org if you have questions or comments with respect to content, or if you wish to obtain copyright permission for your intended uses that do not fall within these terms, or for permission to use the ADB logo.

The ADB Sustainable Development Working Paper Series presents data, information, and/or findings from ongoing research and studies to encourage exchange of ideas and elicit comment and feedback about development issues in Asia and the Pacific. Since papers in this series are intended for quick and easy dissemination, the content may or may not be fully edited and may later be modified for final publication.

Corrigenda to ADB publications may be found at http://www.adb.org/publications/corrigenda.

Notes:

In this publication, “\$” refers to United States dollars.

ADB recognizes "China" as the People's Republic of China, "Korea" as the Republic of Korea, and "Hanoi" as Ha Noi. 


\section{CONTENTS}

TABLES, FIGURES, AND BOXES V v

FOREWORD vii

ACKNOWLEDGMENTS viii

ABBREVIATIONS Ix - ix

SUMMARY

1. INTRODUCTION 1

2. ELECTRIC VEHICLES AND COMPONENTS 3

2.1. Electric Vehicles in Different Transport Modes 3

2.2. Electric Vehicle Technologies $\quad 5$

2.3. Electric Vehicle Components 10

3. THE ELECTRIC VEHICLE MARKET 12

3.1. Global Outlook 12

3.2. Electric Vehicle Market in Developing Member Countries of ADB 18

4. CHARGING INFRASTRUCTURE AND ENERGY GRID 21

4.1. Charging Infrastructure $\quad 21$

4.2. Energy Usage $\quad 22$

4.3. Smart Charging and Vehicle Grid Integration 24

5. ELECTRIC VEHICLES AND THE ENVIRONMENT 25

5.1. Introduction 25

5.2. Greenhouse Gas Emissions 26

5.3. Other Environmental Impacts $\quad 37$

6. ELECTRIC VEHICLE ECONOMICS

6.1. Profitability of Electric Vehicles 41

6.2. Capital Expenditure-Vehicle 42

6.3. Capital Expenditure-Infrastructure 43

6.4. Operational Expenditure 44

6.5. Lifetime Cost Comparison 47

6.6. Monetizing Environmental Benefits $\quad 47$

6.7. Subsidies and Social Impact 49 
iv Contents

$\begin{array}{ll}\text { 7. POLICIES } & 50\end{array}$

7.1. Overview Policies 50

7.2. Electric Mobility Policies of Developing Member Countries 54

7.3. Potential Policies for Commercial Vehicles 54

8. PRELIMINARY ASSESSMENT OF ELECTRIC VEHICLES' POTENTIAL IN ADB

DEVELOPING MEMBER COUNTRIES AND RECOMMENDED SUPPORT POLICIES

8.1. Electric Vehicle Potential of Developing Member Countries 57

8.2. Recommended Electric Vehicle Support Policies for ADB 59

9. SELECTED ELECTRIC VEHICLE IMPLEMENTATION CASES IN ASIA 60

9.1. Introduction 60

9.2. E-Buses in the People's Republic of China 60

9.3. Electric 3-Wheelers in Nepal 68

9.4. Battery Swap Scooters in Taipei,China 70

9.5. Electric Car-Sharing Program in Singapore 72

10. CONCLUSIONS AND RECOMMENDATIONS FOR ACTIONS 74

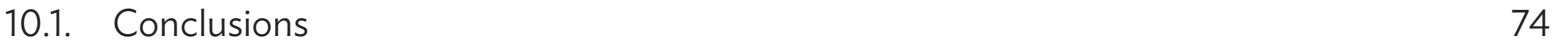

$\begin{array}{ll}\text { 10.2. Policy Focus } & 75\end{array}$

11. COUNTRY CASE STUDIES

$\begin{array}{ll}\text { 11.1. Overview } & 78\end{array}$

11.2. Hanoi: Electric Motorcycles 78

11.3. Dhaka: Electric Rickshaws and Electric Pedicabs 80

11.4. Udaipur: Electric Rickshaws 82

11.5. Manila: Electric Jeepneys 86

11.6. Fiji: Electric Cars and Renewable Grid Integration 87

11.7. Tbilisi: Electric Buses 93

11.8. Yerevan: Electric Buses 96

11.9. Karachi: Electric Buses and Integration with Electric Last-Mile Connectivity 98

11.10. Bangkok: Electric Trucks 101

\section{APPENDIXES}

$1 \quad$ Greenhouse Gas Emissions Baseline Vehicle 103

$2 \quad$ Emission Impact per Vehicle Category 107

$\begin{array}{ll}\text { REFERENCES } & 111\end{array}$ 


\section{TABLES, FIGURES, AND BOXES}

\section{Tables}

1 Vehicle Power Trains $\quad 5$

2 Charging Systems and Battery Packs 10

3 Typical Battery Sizes per Electric Vehicle Category 11

4 Grid Carbon Factors of ADB Developing Member Countries 30

5 Greenhouse Gas Reduction Potential with Deployment of Electric Vehicles 33

6 Vehicle Emission Standards in ADB Developing Member Countries 37

7 Average Fossil Fuel Prices of ADB Developing Member Countries, as of June 2018

8 Pollution Costs of ADB Developing Member Countries, 2014

9 Potential Impact of Electric Vehicle Subsidy Schemes 50

10 E-Mobility Policies of ADB Developing Member Countries, as of July 2018

11 Assessment Criteria, Parameters, and Benchmarks 58

12 Environmental Potential of Electric Vehicles in ADB Developing Member Countries 59

13 Charging Systems and Battery Packs 62

14 Environmental Impact of Electric Vehicles in Viet Nam 78

15 Environmental Impact of Electric Vehicles in Bangladesh 80

16 Cost of Rickshaws in Dhaka $\quad 81$

17 Environmental Impact of Electric Vehicles in India 83

18 Diesel versus Electric Rickshaws in Udaipur 84

19 Environmental Impact of Electric Vehicles in the Philippines 86

20 Greenhouse Gas Emissions in Fiji, 2014

21 Environmental Impact of Electric Vehicles in Georgia 94

22 Environmental Impact of Electric Vehicles in Armenia 96

23 Environmental Impact of Electric Vehicles in Pakistan 99

24 Comparison Diesel and Electric Bus for Karachi (12-Meter Standard Urban Bus 100

25 Environmental Impact of Electric Vehicles in Thailand 101

\section{Figures}

1 Greenhouse Gas Transport Emissions World Reference Scenario (Well-to-Wheel in $\mathrm{MtCO}_{2} \mathrm{e}$ ) 1

2 Global Vehicle Stock, Distance Traveled, and Well-to-Wheel Greenhouse Gas Emissions, 2015

3 Transport Modes and Electric Vehicles 4

4 System Diagram-Conventional, Hybrid, and Electric Vehicle 6

5 Projected New Vehicle Sales of Central High Technology Scenario 6 of the European Climate Foundation

6 Energy Savings-Urban Hybrid Buses $\quad 7$

7 Energy Usage-Standard Urban 12-Meter Bus 9

8 Maximum Driving Range of 12-Meter Battery Electric Buses with 250 Kilowatt-Hour

9 Battery Electric Passenger Car Stock, 2013-2017 13

10 Battery Electric Car Stock in Norway, 2005-2017 14

11 Electric Vehicle Market Adoption $\quad 15$

12 Reasons for Not Purchasing Electric Vehicles in the People's Republic of China 16

13 Key Concerns of Consumers of Electric Vehicles 16

14 Projected Share of 2-Wheelers in Major Asian Regions 17 and the Organisation for Economic Co-operation and Development

15 People's Republic of China Electric Bus Sales and Share of Total Bus Sales 18 
16 Projected Market Share of Urban Bus Technologies in Europe

17 Projected Global Freight Activity and Well-to-Wheel Greenhouse Gas Emissions, 2015-2050

18 Public Charging Infrastructure and Electric Vehicles in Cities

19 Impact of Electric Vehicle Deployment on Global Electricity Demand

20 Unmanaged Charging versus Smart Charging

21 Emissions Sources of Vehicles

22 Average Tank-to-Wheel Greenhouse Gas Emissions of Standard Vehicle Categories

23 Lifetime Tank-to-Wheel Greenhouse Gas Emissions per Vehicle Category

24 Average Well-to-Wheel Greenhouse Gas Emissions of Standard Vehicle Categories

25 Benchmark Grid Factor for Electric Vehicles

26 ADB Developing Member Countries with a Fast Greening of the Electricity Grid

27 ADB Developing Member Countries with a Slow Greening of the Electricity Grid

28 Life Cycle Emissions-Passenger Car and Bus

29 Greenhouse Gas Emissions Operations-Battery Buses, Urban Trucks, and Taxis

30 Greenhouse Gas Emissions Operations-Battery Cars, Motorcycles, and Rickshaws

31 Nitrogen Oxide Emissions-Light Vehicles

32 Nitrogen Oxide Emissions-Heavy Vehicles

33 Particulate Matter Emissions - Light Vehicles

34 Particulate Matter Emissions-Heavy Vehicles

35 External Noise Levels of a Bus When Departing from the Bus Stop 41

36 Electric Passenger Car-Cost Component

37 Past and Future Expected Battery Costs

38 Comparison of Total Cost of Ownership of Buses in the People's Republic of China 45

39 Fossil Fuel Prices in ADB Developing Member Countries, as of June 2018

40 Total Cost of Ownership between Conventional and Electric Vehicles 48

41 Perceived Importance of Norway's Support Policies

42 Electric Vehicle Market Share and Purchase Subsidies-Electric Passenger Cars in Cities in the People's Republic of China

43 Fiscal Incentives and Electric Vehicle Market Uptake

45 Average Well-to-Wheel Greenhouse Gas Emissions of Urban Buses in the People's Republic of China, 2016

46 Capital Expenditure Comparison With versus Without Subsidies-Standard Urban 12-Meter Bus in the People's Republic of China, 2016-2017

47 Total Cost of Ownership of Different Bus Technologies in the People's Republic of China, 2016

48 Recommended Areas for Action $\quad 76$

49 Vehicle Distribution in Fiji, 2014

50 Greenhouse Gas Road Transport Sector Scenarios in Fiji 89

51 Projected Number of Electric Cars and Buses in Fiji, 2020-2050 89

52 Greenhouse Gas Mitigation Impact of Electric Cars and Buses in Fiji (Direct Emissions) 90

53 Projected Electricity Usage in Fiji per Sector (Very High Ambition Scenario) 91

54 Projected Peak Power Demand from Electric Mobility in Fiji (Scenario 4) 92

55 Greenhouse Gas Emissions-8-Meter and 10-Meter Urban Buses in Georgia 95

56 Greenhouse Gas Emissions-8-Meter and 10-12-Meter Urban Buses 98

\section{Boxes}

1 Greenhouse Gas Impact of Rail Electrification 5

2 Why the Combined Margin Approach Is Not Appropriate for Electric Vehicles 29

3 Optimization of E-Bus Configuration 


\title{
FOREWORD
}

Mobility is an essential instrument of social and economic development. The mass production of fossil fuel-based internal combustion engines (ICE) in the early 20th century revolutionized mobility by extending travel distances and reducing travel times. As a result, motorized vehicles played a key role in shaping human settlement and activity patterns. However, the need for increased mobility is going unmet in many parts of the developing world. Addressing these mobility needs will require a substantial increase of vehicles and services of one type or another, together with supportive transport policies and infrastructure development.

Despite the convenience and contribution of motor vehicles to social and economic development, their negative externalities, such as pollution, and increased greenhouse gas emissions have not been fully acknowledged nor consistently factored into all level of policy or personal decisions when a mode of transport is chosen. How then can the need for mobility be met with minimal impact to human health and the environment?

Electric vehicles (EVs) are rapidly emerging and offer a promising solution for alleviating the health and environmental burdens caused by the transport sector in what is called a "clean disruption." EVs are gaining momentum in light of recent announcements by several major car manufacturing countries to ban ICE car sales in the near future, and the plans of major cities to restrict cars using diesel engines from their urban centers. In contrast to these bans, there is increased enthusiasm for EVs, with many developing countries and cities committing to EV deployment to varying degrees and business communities stepping in to provide business models to promote their adoption.

Despite the growing sales of EVs and announcements of policy and deployment plans by many countries and cities, the current number of EVs is still too small to produce any meaningful impact on emissions reduction. EVs are projected to reach a competitive pricing compared to ICE cars by the 2020s, resulting in a significantly higher share of electric car sales globally, and it is estimated that the number of EVs around the world will reach 125 million by 2030 .

The electrification of transport is no longer in doubt, but an ongoing trend. We must choose the right path to enable electrified transport and help prevent and arrest increasing pollution and higher greenhouse gas emissions. To do this requires concerted efforts and strategic decision-making at multiple levels of government and industry that are involved in the policies and manufacturing of electric vehicles, the construction of charging stations, the provision of mobility services, the mix of the energy supply, and interactions with financial institutions.

This publication compiles knowledge and data on electric vehicle options in developing Asia, and provides the results of further consultations done with stakeholders in selected countries. The insights and recommendations presented here can be used by policy makers and transport company managers who are interested in promoting electric vehicles, in order to design the appropriate policies to support electric vehicle adoption, and to choose the appropriate modes and models for their countries and cities.

\author{
WooChong Um \\ Director General \\ Sustainable Development and Climate Change Department \\ Asian Development Bank
}




\section{ACKNOWLEDGMENTS}

This publication was produced as a part of TA-9420 Implementation of Sustainable Transport for All under ADB's Sustainable Development and Climate Change Department-Sector Advisory Service Cluster. The TA team consists of Ki-Joon Kim, Principal Transport Specialist (Team Leader), Hun-Ki Lee, Transport Specialist (Secondee from Korea Transport Institute), Dae Kyung Kim, Senior Energy Specialist managed the technical assistance and administrative support was provided by Diana Marie Hernandez-Louis.

The team of experts who prepared the technical assistance report are Jürg Grütter, Grütter Consulting and Prof. Sekyung Han, Kyungbuk Nation University, Republic of Korea.

We would like to express our sincere gratitude to the Georgia Resident Mission, Armenia Resident Mission and Viet Nam Resident Mission for providing support for the consultation with the government counterparts.

Special thanks to the peer reviewers, Steve Lewis-Workman, Unit Head, Project Administration, Kyrgyz Republic Resident Mission and Gloria Gerilla-Teknomo, Senior Transport Sector Officer, East Asia Department for their valuable comments and suggestions for the improvement of the publication. 


\section{ABBREVIATIONS}

$\begin{array}{ll}\text { ADB } & \text { Asian Development Bank } \\ \text { BC } & \text { black carbon } \\ \text { BEB } & \text { battery electric bus } \\ \text { BEV } & \text { battery electric vehicle } \\ \text { BRT } & \text { bus rapid transit } \\ \text { CAPEX } & \text { capital expenditure } \\ \text { CNG } & \text { compressed natural gas } \\ \text { CO } & \text { carbon dioxide } \\ \text { DMC } & \text { developing member country } \\ \text { DPF } & \text { diesel particle filters } \\ \text { DSM } & \text { demand side management } \\ \text { e-bus } & \text { electric bus } \\ \text { e-jeepney } & \text { electric jeepney } \\ \text { e-mobility } & \text { electric mobility } \\ \text { e-motorcyle } & \text { electric motorcycle } \\ \text { e-pedicab } & \text { electric pedicab } \\ \text { e-rickshaw } & \text { electric rickshaw } \\ \text { e-truck } & \text { electric truck } \\ \text { EU } & \text { European Union } \\ \text { EV } & \text { electric vehicle } \\ \text { FCEV } & \text { fuel cell electric vehicle } \\ \text { GHG } & \text { greenhouse gas } \\ \text { HDV } & \text { heavy-duty vehicle } \\ \text { HEV } & \text { hybrid electric vehicle } \\ \text { ICCT } & \text { International Council on Clean Transportation } \\ \text { ICE } & \text { internal combustion engine } \\ \text { IEA } & \text { International Energy Agency } \\ \text { LCB } & \text { low-carbon bus } \\ \text { mtCO } \text { e } & \text { metric ton of carbon dioxide equivalent } \\ \text { NAMA } & \text { Nationally Appropriate Mitigation Action } \\ \text { NDC } & \text { Nationally Determined Contribution } \\ \text { NO } & \text { nitrogen oxide } \\ \text { OECD } & \text { Organisation for Economic Co-Operation and Development } \\ \text { OPEX } & \text { operational expenditure } \\ \text { PHEV } & \text { plug-in hybrid electric vehicle } \\ \text { PM } & \text { particulate matter } \\ \text { PRC } & \text { People's Republic China } \\ \text { SOC } & \text { state of charge } \\ \text { t } & \text { ton } \\ \text { TCO } & \text { total cost of ownership } \\ \text { TTW } & \text { tank-to-wheel } \\ \text { UNFCCC } & \text { United Nations Framework Convention on Climate Change } \\ \text { US } & \text { United States } \\ \text { V2G } & \text { vehicle-to-grid } \\ \text { WTT } & \text { well-to-tank } \\ \text { WTW } & \text { well-wheel } \\ & \end{array}$




\section{SUMMARY}

\section{Context}

A well-functioning transport sector is vital for the economic and social development of countries. Transport affects the global climate through its emissions, and pollutants reduce air quality and have negative impacts on human health and ecosystems. In 2015, the transport sector emitted around 7.5 billion tons $(\mathrm{t})$ of carbon dioxide $\left(\mathrm{CO}_{2}\right)$ representing $18 \%$ of all man-made $\mathrm{CO}_{2}$ emissions. ${ }^{1}$ The International Energy Agency (IEA) projects 50\% higher transport emissions by 2060, with strong growth especially in trucks and buses, while cars, small buses, and trucks with less than $3.5 \mathrm{t}$ would remain at current emission levels.

The majority of Nationally Determined Contributions identify transport as a mitigation priority. Multiple countries in Asia made electric mobility (e-mobility) pledges. The electrification of transport is one of the megatrends in mobility and is an important pillar to achieve its decarbonization.

The focus of this report is on pure electric vehicles (EVs). Hybrid and plug-in hybrid vehicles reduce fuel consumption, but for many countries it is more attractive to move directly from fossil fuel vehicles toward EVs. Fuel cell vehicles are not included due to large energy usage for the production of hydrogen, with three times higher energy usage than EVs resulting in potentially higher greenhouse gas (GHG) emissions than fossil fuel vehicles. The report also focuses on road transport including all vehicle categories. Electrification is also an option for rail, shipping, and, in the future, for aviation.

\section{The Electric Vehicle Market}

By 2017, 3 million electric and plug-in hybrid cars were plying the world's roads. EV sales are increasing worldwide, but are still disproportionally concentrated in few countries, with $80 \%$ of all EVs being sold in just three countries: the People's Republic of China (PRC), Norway, and the United States. EV sales are not only focused on certain countries, but also concentrated in a few metropolitan areas, with just 20 cities accounting for around $40 \%$ of the world's electric passenger cars. By 2020, it is projected that 4.5 million EVs could be sold (i.e., around $5 \%$ of the global passenger car sales) and by 2030, this figure could reach $20 \%$ of global vehicle sales. ${ }^{2}$

In 2017, around 3 million chargers were installed, of which around 330,000 units were publicly available slow or fast chargers (two-thirds slow chargers and one-third fast chargers). ${ }^{3}$ Publicly accessible infrastructure, especially fast chargers, is growing rapidly. The number of fast chargers is important as concerns about charging facilities are among the main reasons why consumers do not purchase EVs.

The PRC dominates the electric two-wheeler market with a vehicle stock estimated at 200 million to 230 million units. ${ }^{4}$ Other countries in Asia with notable shares of electric 2- and 3-wheelers include Bangladesh, India, Nepal, and Viet Nam.

\footnotetext{
International Energy Agency. Tracking Progress: Transport. https://www.iea.org/etp/tracking2017/transport/.

McKinsey. 2018a. The Global Electric-Vehicle Market Is Amped Up and on the Rise.

3 IEA. 2018b. Global EV Outlook 2018. Paris. Fast chargers include AC 43 kilowatt chargers, DC chargers, Tesla Superchargers, and inductive chargers.

4 IEA. 2017b. Global EV Outlook 2017. Paris. Total 2-wheeler sales worldwide in 2017: around 30 million (IEA. 2018b. Global EV Outlook 2018. Paris.).
} 
In 2017, there were nearly 400,000 electric buses operating worldwide, with $99 \%$ of the total in the PRC. ${ }^{5}$ Electric buses or e-buses in the PRC made up around $17 \%$ of the total bus fleet and $22 \%$ of new bus sales, with many cities electrifying completely their urban bus fleets within the next few years. Electric trucks circulate in small numbers. However, electric urban delivery trucks recently surged as a viable alternative with multiple manufacturers entering the market. It is expected that after 2025, light- and medium-duty electric trucks could start to penetrate the market massively (with heavy-duty trucks to follow later). ${ }^{6}$

\section{Electric Vehicles and the Grid}

The number of chargers per vehicle will depend largely on the country, the density of EVs, and the power of chargers. Leading EV countries have a large number of public charging points-however, there is no universal benchmark for the ratio of EVs to chargers. For example, California has 25 to $30 \mathrm{EVs}$ per public charger (EV owners have frequent access to home and workplace charging and thus require minimum access to public chargers), while in the Netherlands, the ratio is two to seven EVs per public charger (private parking space is more limited).

Research suggests that the installed electrical capacity required to meet the demand from EVs by 2030 will not be a major constraint. The IEA, in its 2 -degrees Celsius $\left(2^{\circ} \mathrm{C}\right)$ global warming scenario, estimates that the additional generation needed to meet $\mathrm{EV}$ demand represents only $1.5 \%$ of total electricity demand in 2030. However, this statement is not correct in the case of small grids and with large EV penetration rates. For example, the electricity demand from EVs for Fiji-assuming the country would only introduce EVs by 2030 -would be four times higher than the current production level.

Running $100 \%$ EVs not only stresses the grid in electricity production, but also in power demand. EV charging can have a sizable impact on the loads applied to the grid at certain times and locations. The rise in the number of EVs can be accommodated fairly easily by power generation facilities as long as the vehicles are charged off-peak. Faster charging during peak demand, however, can have a significant impact. The extent on which EVs will impact the electricity networks will depend greatly on technologies and charging modes used, with the bulk of charging expected to occur in low-voltage distribution grids in residential or commercial areas.

Therefore, grid management is considered critical rather in terms of absolute capacities. Problems which can occur include increased peak loads and charging hotspots resulting in local network overloading. Solutions proposed for these problems involve controlled charging and smart charging using demand side management (DSM). The effectiveness of DSM can be enhanced by bidirectional "vehicle-to-grid" capabilities where power can flow from the grid to the vehicle and vice versa. This could also be an attractive source of revenue for EV owners. For fast charging, managing power demand is also likely to require the deployment of stationary storage at the local level.

Increasing renewable energy penetration rates requires sufficient energy storage systems due to unpredictability of renewable sources (e.g., wind and solar) especially for small isolated island states. EV fleets could play a role as distributed energy storage systems, thereby helping to increase the share of renewables. Second-life batteries from EVs can also play an important role for storing the fluctuating supply of energy from renewable sources.

5 Bloomberg New Energy Finance. 2018. Electric Buses in Cities.

6 McKinsey. 2017b. What's Sparking Electric-Vehicle Adoption in the Truck Industry? 


\section{Electric Vehicles and the Environment}

EVs have no direct or combustion emissions. Including indirect or upstream emissions caused by energy production and distribution, EVs still perform far better in terms of GHG emissions even if the electric grid is highly powered by fossil fuel. ${ }^{7}$ The Asian countries with the largest GHG impact when using EVs are those with a high share of renewable electricity production such as Armenia, Bhutan, Georgia, the Kyrgyz Republic, the Lao People's Democratic Republic, Nepal, and Tajikistan, while countries with a high carbon factor in electricity production such as India, Indonesia, Kazakhstan, Mongolia, and Turkmenistan will only result in limited GHG reductions by deploying EVs.

GHG emissions also result from the production of vehicles and their components, specifically in the case of EVs from batteries. The impact of GHG emissions caused by battery production is reduced because EV batteries can be used for stationary applications after terminating their useful life span on the vehicle. Also, EVs save on vehicle manufacturing-related emissions, due to less usage of materials used for engine manufacturing, less or no usage of oils and lubricants, and a longer life span of the vehicle due to less vibrations and longer-lasting parts. For buses and trucks, upstream manufacturing emissions account for less than 5\%-10\% of total GHG emissions while for passenger cars the figure is 15\%-30\% (depending on the electric grid). In all cases, even if including all upstream and downstream emissions, EVs will result in significant GHG reductions if the grid factor is below 0.8 kilogram of carbon dioxide equivalent emission per kilowatt-hour $\left(\mathrm{kgCO}_{2} \mathrm{e} / \mathrm{kWh}\right)$.

EVs not only reduce GHG emissions, but also reduce local pollutants, including particle matter, nitrogen oxide, and sulfur dioxide. The magnitude of the impact will depend largely on the prevailing vehicle emission standards of the country and the type of vehicle replaced (fuel type and vehicle category). In general, it can be stated that pollution impacts will be significant if urban buses, trucks, diesel passenger cars, and 3-wheelers are replaced. Even if such vehicles theoretically comply with stringent emission standards, the practical experience is diesel vehicles are not well maintained and real-world emissions are far higher than what vehicle manufacturers claim. Clean air in urban areas is not achievable with usage of diesel vehicles. EVs also have significantly lower noise levels especially during the start and stop process, and at low speeds where engine noise dominates.

The impact on GHG reductions will be far higher by deploying commercial EVs instead of private units due to higher fuel usage, higher mileage, and longer life span of commercial vehicles. Replacing one urban diesel bus with an electric unit has the same impact as replacing 35 fossil fuel passenger cars or 300 motorcycles. Therefore, a focus on commercial vehicles maximizes the emission impact.

\section{The Economics of Electric Vehicles}

The profitability of EVs will depend basically on (i) the level of fossil fuel prices, (ii) the level of electricity prices, (iii) the financial incentives for $\mathrm{EVs}$, and (iv) the nonfinancial incentives for EVs. The significant up-front subsidies given from countries with high EV numbers is a clear indication they are currently are not considered as financially profitable. As an example, Norway, which has the highest share of electric cars, subsidizes $45 \%$ of the EV price; and the PRC, which has the largest number of electric cars, subsidizes $23 \%$ of the total price while also giving numerous other benefits. ${ }^{8}$

The capital expenditure (CAPEX) of an EV can be broken down largely into the cost of its battery (40\%-50\%), electric power train (about 20\%), and other elements of the vehicle itself

7 EVs have lower GHG emissions than fossil comparable vehicles up to a grid factor of $1.2 \mathrm{kgCO} / \mathrm{kWh}$

8 McKinsey. 2017d. Dynamics in the Global Electric-Vehicle Market. 
(30\%-40\%). ${ }^{9}$ The CAPEX of EVs is significantly higher than of conventional vehicles. The purchase cost remains the most cited barrier to entry of potential EV customers. Also, many EVs will require battery replacement (especially buses and trucks) during their commercial life span, thus incurring a significant replacement investment.

EV costs are declining rapidly basically due to cost reductions of batteries. Not only has the battery cost per kilowatt-hour ( $\mathrm{kWh}$ ) declined, but at the same time, the battery energy density and the vehicle efficiency has increased. This results in either longer driving ranges with the same battery pack or a smaller battery pack, thus reducing vehicle costs beyond the battery cost reduction per $\mathrm{kWh}$. Another important component is that low-cost, fast-charging options have surged, thus allowing vehicles to use smaller battery packs with more frequent intermediate fast-charging.

A higher CAPEX of the vehicle can be recovered either through (i) lower operational expenditure (OPEX) and/or (ii) a longer lifetime of the vehicle. In the case of buses, for example, batteries are guaranteed as of 2018 by most manufacturers for 8 years with a state of charge (SOC) of $80 \%$. EVs have a longer technical life span than conventional vehicles due to having less parts and less vibrations.

Compared to fossil fuel vehicles, EVs have better energy efficiency and far lower energy costs. These advantages result in lower maintenance costs due to less liquids used, fewer pre-emptive inspections, and less wearing out on mechanical parts that require replacement (including brake pads). However, EV tire usage is 20\%-30\% higher (due to increased weight and faster acceleration and de-acceleration), ${ }^{10}$ spare parts tend to be more expensive (due to lack of a secondary spare parts market), standstill times are often longer, and maintenance staff tends to be more expensive due to higher required qualifications. Including tires, overall maintenance costs of EVs are around $60 \%-80 \%$ higher than conventional vehicles. ${ }^{11}$

While fuel costs can easily be determined for fossil fuel vehicles, the same is not true for electricity costs of EVs. Electricity prices depend on the time the vehicle is charged and the power factor. Depending on the system configuration, electricity costs for an EV can vary by factor 3. An optimal system configuration of the battery pack on board the vehicle and the charging infrastructure is essential to reduce costs of EVs, especially for commercial operators of buses and trucks.

\section{Electric Vehicle Policies}

Policies are often grouped into price or financial incentives and nonprice measures. In countries with high EV uptake, both measures have been taken.

Financial incentives are given for vehicles as well as charging infrastructure either as direct subsidies, fiscal incentives, or reduced energy costs. Zero emission vehicle mandate programs such as in California or the new EV policies in the PRC also result in financial incentives for EVs as car manufacturers need to comply with specific targets, lowering the price of EVs. Specific support for public charging infrastructure for passenger cars is considered as essential as a positive business case for private companies to become involved is difficult as long as EVs account for a small share of total vehicles.

9 McKinsey. 2018b. Three Surprising Resource Implications from the Rise of Electric Vehicles.

10 Grütter Consulting. 2018. Low Carbon Buses in PRC, for buses; or UBS. 2017. UBS Evidence Lab Electric Car Teardown Disruption Ahead?, for e-cars.

11 See UBS. 2017. UBS Evidence Lab Electric Car Teardown - Disruption Ahead?, for maintenance cost comparison passenger cars excluding tires; or Grütter Consulting. 2018. Low Carbon Buses in PRC, for maintenance savings of e-buses. 
A number of cities give special incentives for fleet programs including taxis, car-sharing services, or car rentals. This has been successful in increasing the market share of EVs. Fleet operators send a demand signal to the market and act as amplifiers in promoting the uptake of EVs by their staff and customers. Government fleets and fleets controlled through public regulations such as service vehicles, including garbage trucks and public transport buses, are also good targets for electric fleet policies.

Nonprice incentives depend very much on the country, and should be related to factors which influence purchase decisions of potential EV customers, including special lane access, parking perks, exemption from road and congestion charges, and exemption from driving and purchase restrictions.

National policies are basically targeted toward fiscal incentives. The largest impact from fiscal incentives is achieved if the EV purchase premium is reduced. Nonfinancial incentives are basically developed at the municipal level and result in cities having a decisive influence in the adoption of EVs. Policies that have been especially successful in this context include waivers on regulations that limit the availability of license plates (e.g., implemented in many cities in the PRC), exemptions from access to restricted urban areas, and exemptions from usage fees for road networks or parking fees.

A different financial structuring can also be potentially an important tool for EV promotion, such as leasing. While capital costs are higher for EVs, their operation costs are lower. Spreading out the initial investment over the commercial life span of the vehicle makes total annual costs of an EV for a customer similar to a conventional vehicle, as higher annual vehicle costs are matched with lower energy and maintenance costs.

An important long-term policy is also the ban on fossil fuel vehicles. Countries such as India and the PRC have proclaimed plans to ban fossil fuel vehicles, with the earliest being Norway (targeting to ban fossil fuel vehicles by 2025), and many countries targeting from 2030 to 2040. Multiple cities have also announced plans to ban diesel vehicles, including Paris, Rome, and Madrid.

In most countries, policies are directed toward private vehicles, with limited attention given to commercial vehicles, although these would have a far bigger impact. Policies that could be deployed for promoting e-buses include requiring operators to have a gradually increasing share of e-buses in their fleets, requiring new licensed routes to be operated by e-buses, favoring e-buses in public tendering of routes, subsidizing charging infrastructure, implementing up-front purchase subsidies, limiting access to the city center to e-buses, supporting the creation of entities that purchase large fleets of e-buses and lease them to operators, and requiring all buses to be electric by a certain date. Similar policies can also be applied to (urban) truck fleets and to taxi and shared mobility operators.

\section{Recommendations}

It is recommended to structure EV policies and instruments around the three principles: focus, optimization, and incentives.

Focus includes a concentration on high-mileage vehicles, on cities, and on large fleets:

- High-usage EVs lead to a significant impact on the environment, particularly on lowering GHG emissions, while the financial profitability of such EVs is better as the higher CAPEX is compensated quicker with lower operational costs due to the high mileage. This means targeting buses, trucks, taxis, mobility-as-a-service provider, car sharing, and rickshaws. 
- A focus on EVs used primarily in cities reduces the need for costly charging infrastructure and provides for the biggest impact for air pollution and noise as these are main concerns in urban areas.

- A focus on fleet managers and on large fleets reduces costs. EV deployment can be more efficient through leasing companies and vehicle aggregators, especially in countries where transport service providers are small companies.

Optimization refers to charging infrastructure, battery usage, and greening the grid:

- Optimizing the charging infrastructure together with the vehicle configuration reduces costs. Options include assessing the optimal mix between battery pack and charging type (slow, fast, or ultra-fast), solar charging systems, and especially for small island-states linking renewable grids with electric cars on a vehicle-to-grid base.

- Batteries can be a problem, but they can also be a possible solution. Second-life options of EV batteries are potentially an interesting source of revenue. Lead batteries, which are still often used in 2- and 3-wheeler EVs, have a very limited life span and recycling them is often related with a large environment and health impact. Thus, incentives for lead-powered EVs should be phased out. At an early stage, battery recycling and re-usage policies should be put in place, obliging vehicle vendors to take back batteries and use them in secondary applications or recycle them. An up-front recycling charge could be lifted on the sale of batteries, which then feeds into a recycling and re-usage fund.

- In countries with a grid factor of over $0.8 \mathrm{kgCO}_{2} \mathrm{e} / \mathrm{kWh}$, greening the grid should be the first priority. The impact of EVs on GHG reduction in such countries will be small with high marginal abatement costs. Starting first with EVs or greening the grid in parallel to promotion of EVs is not considered an effective strategy since grid greening, in general, takes a lot of time due to the long life span of energy production units.

Appropriate incentive structures include financial and nonfinancial incentives as well as a creative packaging of incentives:

- Financial incentives are critical toward reducing up-front costs and establishing charging infrastructures. However, an important parameter affecting EV profitability is also the fossil fuel price. Reducing fossil fuel subsidies and putting environmental taxes on fossil fuels will promote the shift toward EVs and is equitable as it follows the polluter-pays-principle.

- Cities have multiple instruments at their disposal to promote EVs, including city access restrictions, preferential lanes and parking access, preferential access for EVs, and demanding increasing shares of EVs in transport fleets. Such incentives can turn business models based on EV fleets profitable. For motorcycles, financial incentives have proven to be important, but not decisive. Even if electric scooters (e-scooters) have the same price tag as conventional motorcycles, customers will still be reluctant to purchase them due to anxieties over range, speed, power, and reliability. The core nonfinancial incentive to promote e-scooters is clearly to ban fossil-powered motorcycles from entering cities.

- Incentives should be targeted toward vehicles with high impact and toward sustainable business models. Subsidizing public charging infrastructure in cities is a good start. Incentives are often too much targeted toward private-vehicle owners, with a limited impact and a high cost. Linking subsidies to vehicle usage and mileage is more efficient. Access to capital, guarantee schemes, and nonfinancial incentives should be explored next to traditional up-front subsidies, which have proven to be effective (if sufficiently high), but very costly. Financial subsidies to private EV owners should be fiscally neutral and be paid by fossil fuel car owners to avoid negative social impacts. 



\section{INTRODUCTION}

A well-functioning transport sector is vital for the economic and social development of countries. Trends and projections relating to passenger and freight volumes suggest strong future growth particularly in the non-Organisation for Economic Co-Operation and Development (OECD) regions. ${ }^{1}$ Transport affects the global climate through its emissions, and pollutants reduce air quality and have negative impacts on human health and natural ecosystems. In 2015, the transport sector emitted around 7.5 billion tons of carbon dioxide $\left(\mathrm{CO}_{2}\right)$, representing $18 \%$ of all man-made $\mathrm{CO}_{2}$ emissions or $23 \%$ of global energy-related emissions ${ }^{2}$ Worldwide, transport emissions have grown by $60 \%$ since 1990 and in non-OECD economies, $\mathrm{CO}_{2}$ transport emissions have grown by factor 2.5 from 1990 to 2013 with a higher growth rate than total $\mathrm{CO}_{2}$ emissions. The reference scenario of the International Energy Agency (IEA) projects 50\% higher transport emissions by 2060 from heavy-duty vehicles (trucks and buses weighing over 3.5 tons) while light-duty vehicles (cars, small buses, and trucks weighing less than 3.5 tons) would remain at current levels (Figure 1).

Light-duty vehicles, together with 2- and 3-wheelers, represent $90 \%$ of all vehicles-however, around $50 \%$ of greenhouse gas ( $\mathrm{GHG}$ ) emissions result from buses and trucks, indicating the importance of these vehicle categories for electrification (Figure 2).

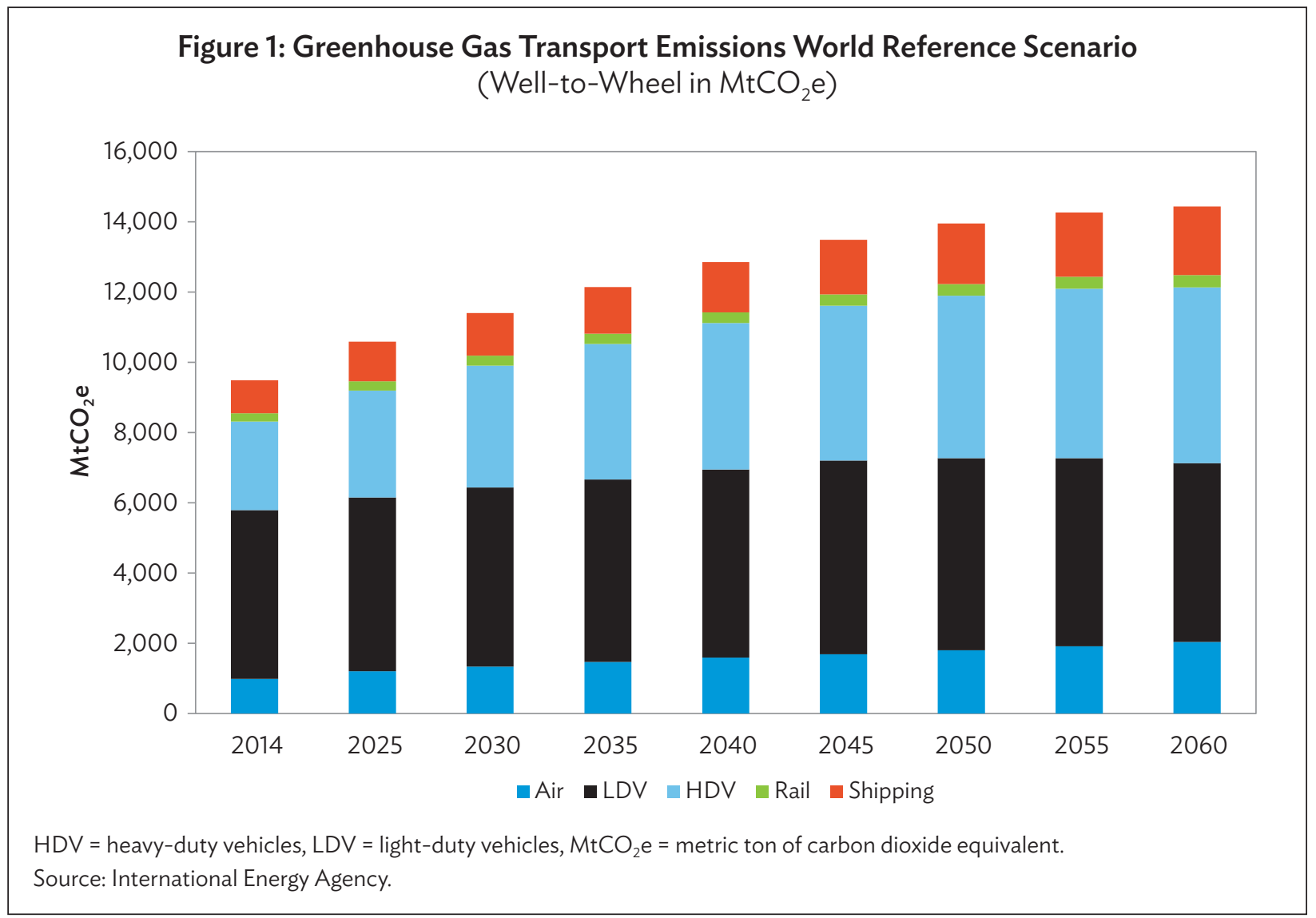

UNECE. 2015. Transport for Sustainable Development.

2 International Energy Agency. Tracking Progress: Transport. https://www.iea.org/etp/tracking2017/transport/. 


\section{Figure 2: Global Vehicle Stock, Distance Traveled, and Well-to-Wheel} Greenhouse Gas Emissions, 2015

(\%)

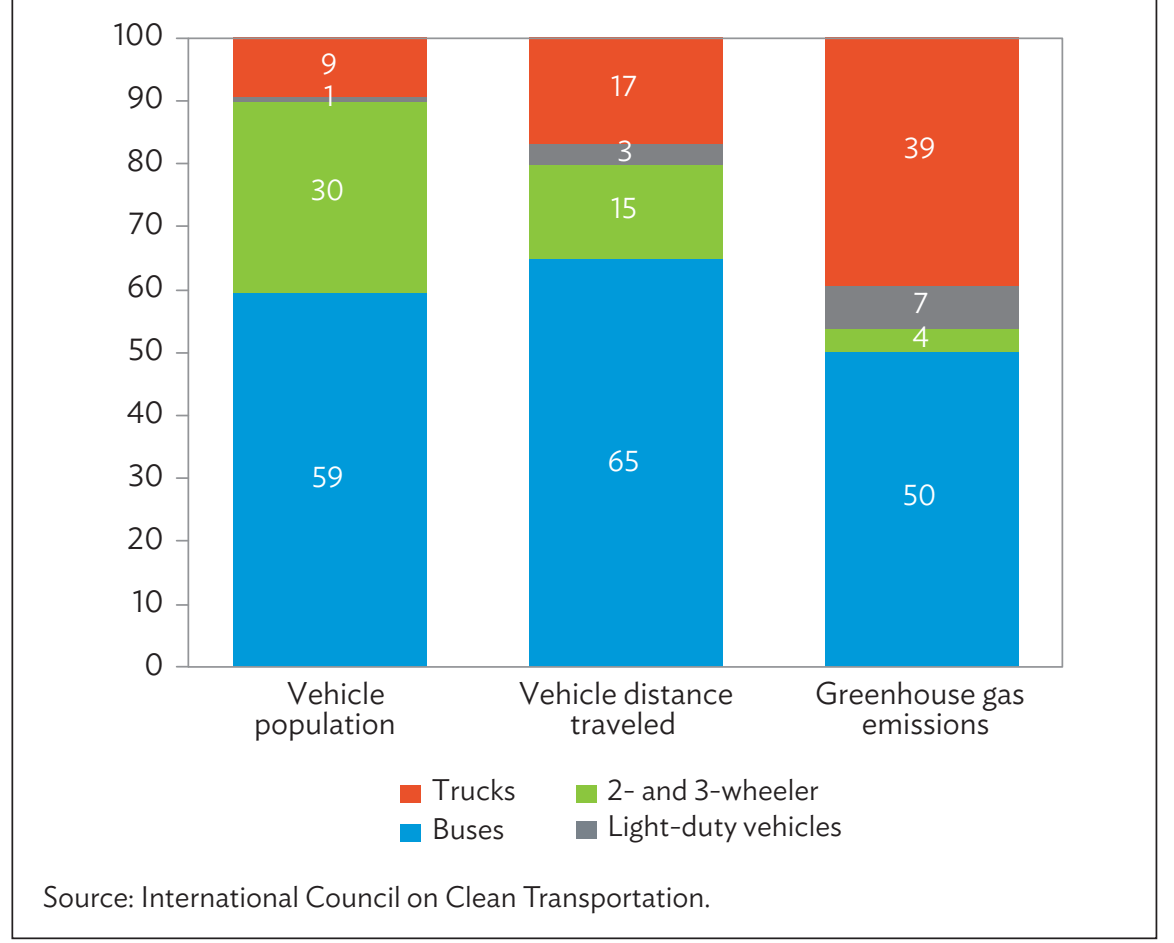

More than three-quarters of Nationally Determined Contributions (NDCs) identify transport as a mitigation priority with a strong bias toward passenger transport. Various NDCs made electric mobility (e-mobility) pledges. The electrification of transport is one of the megatrends in mobility and among various strategies that aim to reduce the sector's environmental impact. Electrification has emerged as a viable technology and an important pillar to achieve the decarbonization of transport. Electric vehicles (EVs) offer a clean alternative to vehicles with internal combustion engines by reducing exposure to air pollution resulting from fossil fuel combustion as well as limiting noise. Many countries have pledged to eliminate fossil fuel car sales or have set targets for EVs. By 2017, 3 million electric and plug-in hybrid passenger cars and around 200 million electric 2 -wheelers were plying the world's roads. ${ }^{3}$ However, EVs still represent less than $1 \%$ of global vehicle sales.

The objective of the report is to understand and deepen the knowledge of factors driving the uptake of EVs such as policy mechanisms, infrastructure requirements, vehicle attributes, and financial-cumbusiness models. The report indicates how these variables could be leveraged and how the Asian Development Bank (ADB) can scale up its investment in e-mobility to promote sustainable transport. The target audience of the report are officials and consultants engaged in transport and EV policies in developing member countries (DMCs) of ADB as well as ADB staff and consultants who work within the transport and urban development areas of the bank.

3 IEA. 2017b. Electric Vehicle Capitals of the World: What Markets Are Leading the Transition to Electric. Briefing. November 2017. 
The report focuses on pure EVs. Hybrids, plug-in hybrid electric vehicles (PHEVs), and fuel cell electric vehicles (FCEVs) are only briefly reviewed. The main reason for the focus on full EVs is that strategies, technologies, and environmental impacts differ between full electric and other vehicles often categorized under EVs, especially PHEVs. The environmental impact of PHEVs depends primarily on the actual charging time. The benefits of e-mobility with PHEVs are therefore difficult to estimate. Focusing on pure EVs also identifies clear strategies and policies, expected impacts, as well as technology choices. The geographical focus of the report is on ADB DMCs. ${ }^{4}$

The report has two primary components:

1. Top-down review of the EV market and deployment, charging technologies including the grid impact, environmental impact, financial and economic aspects, and policies and business models.

2. In-country rapid assessment of potential EV projects and strategies to give insights and ideas of possible interventions and their potential impact. Country case studies give an indication of potential future scenarios and are structured around different vehicle categories.

The outline of the report is as follows:

- Chapter 2 describes the types of EVs and their main components.

- Chapter 3 gives an overview of the current and projected EV market, and the status of EV deployment in ADB DMCs.

- Chapter 4 discusses global and local environmental benefits of EVs.

- Chapter 5 gives an overview of costs associated with EVs relative to fossil fuel-powered vehicles.

- Chapter 6 discusses charging strategies and the impacts of EVs on the energy sector.

- Chapter 7 reviews EV policies and business strategies and their impact.

- Chapter 8 discusses core elements of selected cases in EV promotion in Asia including e-electric buses (e-buses) in the People's Republic of China (PRC), electric car (e-car) sharing in Singapore, battery-swap scooters in Taipei,China; and electric 3-wheelers in Nepal.

- Chapter 9 summarizes core findings of the report.

- Chapter 10 includes country case studies for different vehicle categories in Armenia, Bangladesh, Fiji, Georgia, India, Pakistan, the Philippines, Thailand, and Viet Nam.

\section{ELECTRIC VEHICLES AND COMPONENTS}

\subsection{Electric Vehicles in Different Transport Modes}

EVs are present in all transport modes and vehicle categories (Figure 3).

In air transport, large electric planes are only used on an experimental basis. ${ }^{5}$ Electric drones (e.g., for freight delivery electric planes) are already commercially available.

4 Asian Development Bank. Lending Policies. https://www.adb.org/site/public-sector-financing/lending-policies.

5 S. Calder. 2017. Electric Planes: Could you be flying on a battery-powered aircraft by 2027? Independent. 28 November. https://www.independent.co.uk/travel/news-and-advice/electric-planes-aircraft-rolls-royce-airbus-siemens-easyjet2027-hybrid-a8079841.html 


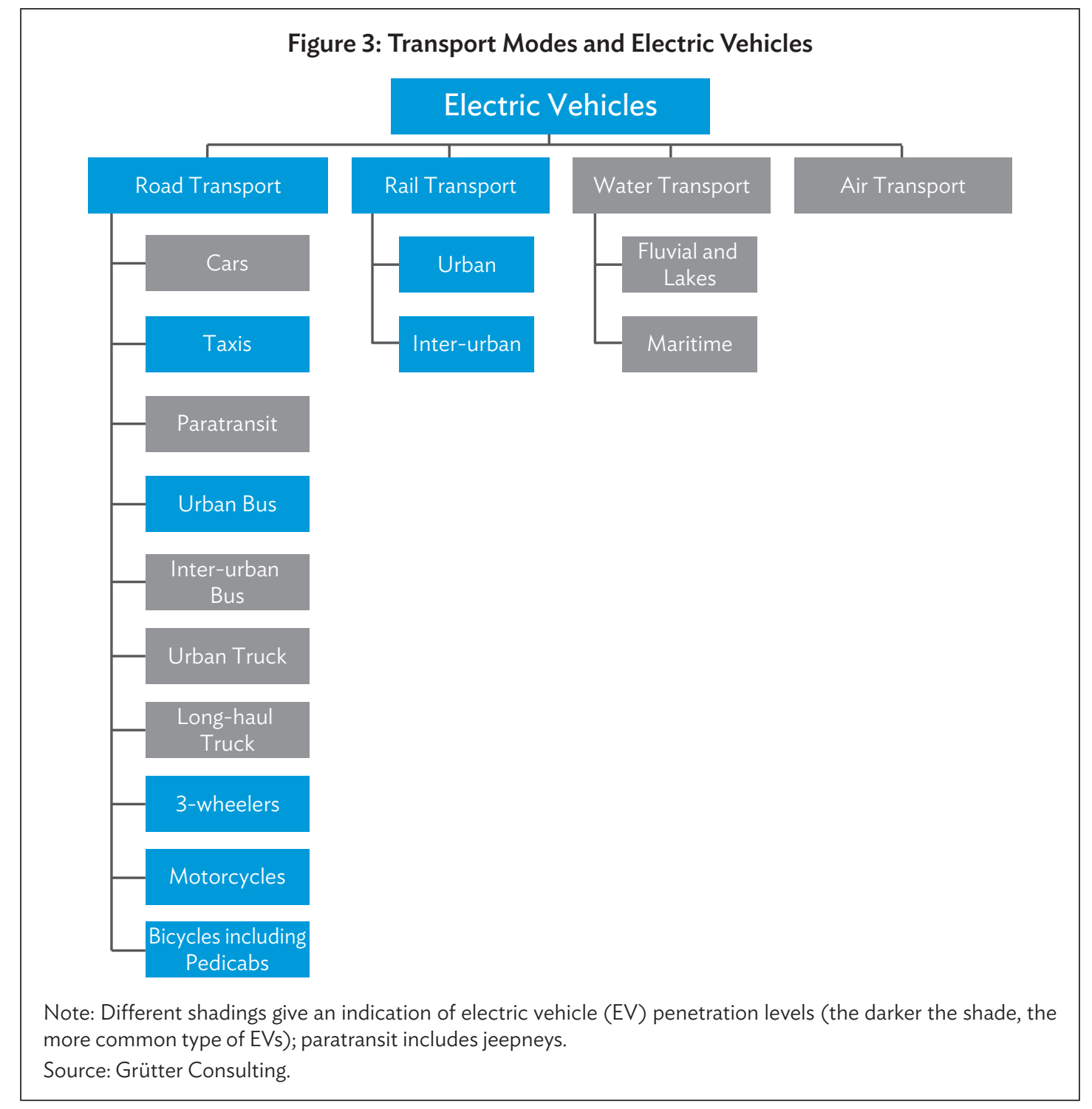

In water transport, some electric ships operate basically for short-haul fluvial and lake applications including cargo ships, ${ }^{6}$ barges, ${ }^{7}$ and ferries. As an example, two ferries operating a 4-kilometer route between Helsingborg (Sweden) and Helsingör (Denmark) are full electric. Each ship is 238 meters long and weighs more than 8,000 tons. ${ }^{8}$ Electrification of short-haul operations could be worthwhile considering, especially in countries with important domestic fluvial transport systems.

In rail transport, electrification is common, especially for urban rail transport including metro and light rail transit and urban cable cars. In intercity rail transport, especially for freight, diesel trains are still very

6 F. Lambert. 2017. A new all-electric cargo ship with a massive 2.4 MWh battery pack launches in China. electrek. 4 December. https://electrek.co/2017/12/04/all-electric-cargo-ship-battery-china/.

7 D. Boffey. 2018. World's first electric container barges to sail from European ports this summer. The Guardian. 24 January. https:/www.theguardian.com/environment/2018/jan/24/worlds-first-electric-container-barges-to-sail-from-europeanports-this-summer.

8 ABB. HH Ferries - Zero Emission operation. https://new.abb.com/marine/references/hh-ferries. 


\section{Box 1: Greenhouse Gas Impact of Rail Electrification}

Sri Lanka uses diesel locomotion on many rail routes. Impactcalculations have been realized for the electrification of the 64-kilometer $(\mathrm{km})$ Panadura-Veyangoda passenger line. With full operations, trains travel a total of around 4.2 million $\mathrm{km}$ annually on this route. Based on an average consumption of 2.5 liters of diesel per $\mathrm{km}$ for the diesel multiple unitsoperating on this route, the annual greenhouse gas (GHG) emission is calculated at 27,000-32,000 ton of carbon dioxide equivalent $\left(\mathrm{tCO}_{2} \mathrm{e}\right)$ (using tank-to-wheel and well-to-wheel calculation approach). Using electro multiple units instead of diesel multiple units, direct GHG emissions drop to zero and direct plus indirect emissions (including emissions from electricity generation and losses) is around $9,000 \mathrm{tCO}_{2} \mathrm{e}$ annually (as of 2015, the grid factor of Sri Lanka is 0.55 kilogram carbon dioxide equivalent per kilowatt-hour $\left.\left[\mathrm{kgCO}_{2} \mathrm{e} / \mathrm{kWH}\right]\right)$. Including direct plus indirect emissions, annual $\mathrm{GHG}$ emission reduction of $23,000 \mathrm{tCO}_{2} \mathrm{e}$ can be achieved. Preliminary calculations show that this investment is potentially profitable (according to a 2005 study by the Institution of Engineers, Sri Lanka), but not attractive enough to be a priority project. Including the environmental impact, however, this type of project might be an interesting option. The annual GHG reduction is equivalent to the GHG emission savings that could be achieved with $6,000-7,000$ electric cars.

Source: Grütter Consulting.

popular. Electrification of rail can therefore be an important action toward lowering GHG emissions of the transport sector.

Road transport is the focus of this report. EVs used in road transport range from 2-wheelers to long-haul trucks, but with different penetration rates. Electrification of 2-wheelers including motorcycles and e-bicycles as well as of urban buses and partially 3 -wheelers and taxis is quite popular in some countries, while electric trucks and EVs for long-haul applications are still very rare.

\subsection{Electric Vehicle Technologies}

The following table shows the types of power trains used for vehicles. The focus of the report is on battery electric vehicles (BEVs). The term EVs is used in this report as synonym for BEVs.

The following graph gives an indication that hybrid and plug-in hybrid power trains are an intermediate technology with full EVs dominating future mobility.

Table 1: Vehicle Power Trains

\begin{tabular}{|c|c|}
\hline Power Train & Definition \\
\hline $\begin{array}{l}\text { Internal combustion } \\
\text { engine }\end{array}$ & $\begin{array}{l}\text { Conventional fossil fuel-powered vehicles with an internal combustion engine (using diesel, } \\
\text { gasoline, or gaseous fuels). }\end{array}$ \\
\hline Hybrid electric vehicles & $\begin{array}{l}\text { Vehicles with an internal combustion engine and an electric drivetrain that can be run in pure } \\
\text { electric mode for a limited range. Micro-hybrids with start-stop technology and regenerative } \\
\text { braking but smaller batteries are often classified under internal combustion engines. }\end{array}$ \\
\hline $\begin{array}{l}\text { Plug-in hybrid electric } \\
\text { vehicle }\end{array}$ & $\begin{array}{l}\text { Vehicles with a larger battery than hybrid electric vehicles and can be plugged in to recharge the } \\
\text { vehicle battery. }\end{array}$ \\
\hline Battery electric vehicle & Full electric vehicles without internal combustion engine. This is the focus of this report. \\
\hline Fuel cell electric vehicle & $\begin{array}{l}\text { Fuel cell electric vehicles are hydrogen-fueled vehicles, which include a fuel cell and a battery- } \\
\text { powered electric motor. }\end{array}$ \\
\hline
\end{tabular}

Source: Grütter Consulting. 

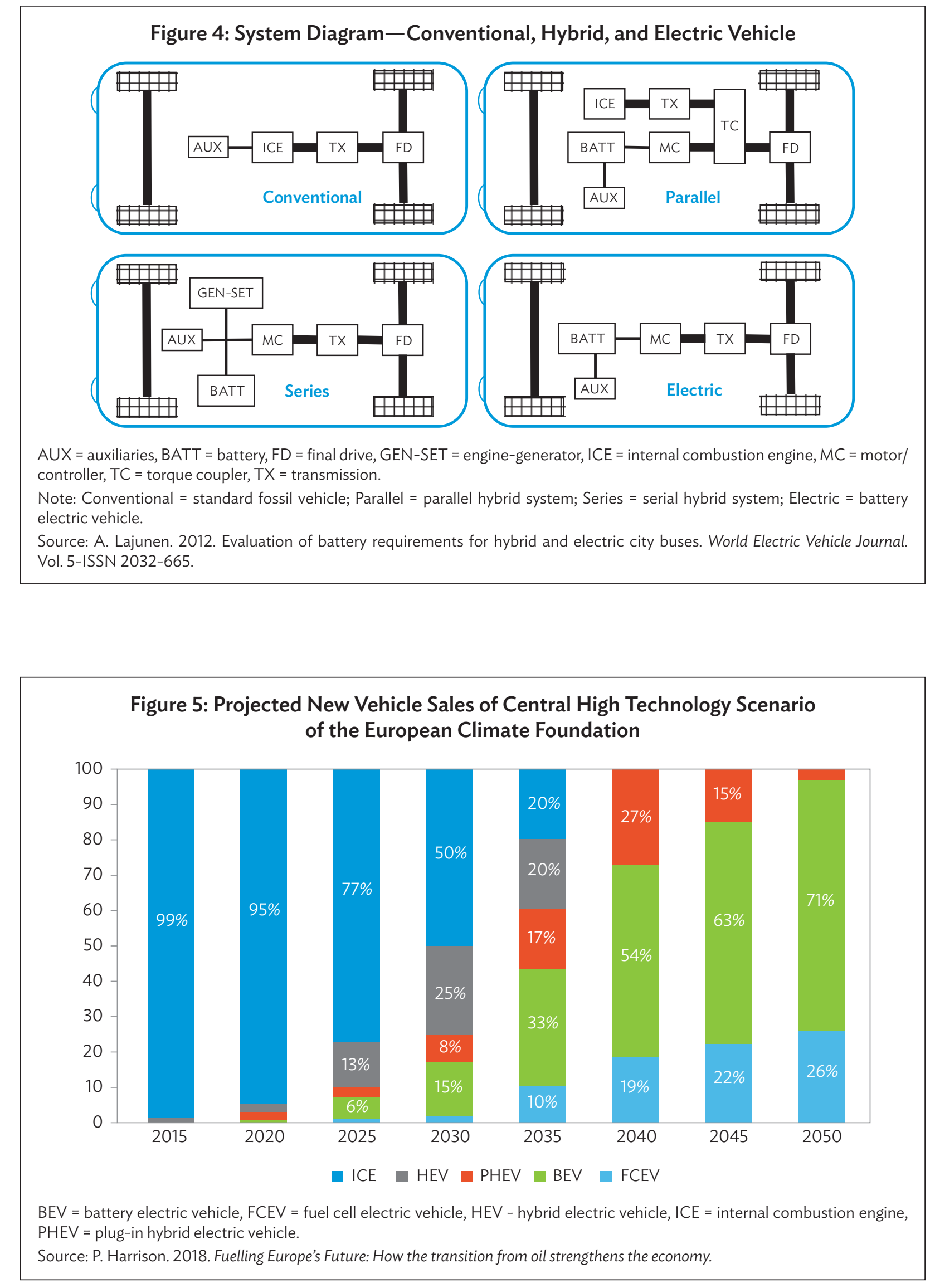


\section{Hybrid Electric Vehicles}

Hybrid electric vehicles (HEVs) are becoming increasingly popular. HEVs are more efficient than conventional vehicles due to regenerative braking, shutting off the internal combustion engine (ICE) during idling, and due to having two sources of onboard power allowing the ICE to be operated near its peak efficiency more often. Based on the US Environmental Protection Agency, hybrid passenger cars reduce fuel consumption by $25 \%-30 \% .{ }^{9}$ The Vincentric study compared directly hybrid with non-hybrid passenger cars of the same make or model and also shows an average of around $25 \%$ improvement in fuel consumption. ${ }^{10}$

Heavy-duty vehicle (HDV) hybrids are basically buses, with very few hybrid trucks in operation. For buses, the major application is urban buses as the best performance, emission reductions, and cost savings of hybrids generally occur when the energy storage system is fully utilized (i.e., cycles with frequent starts and stops, low speeds, and idling as typically prevalent in urban circumstances). Figure 6 shows average fuel savings of hybrid buses in different cities. Data is based on comparing same size and types of conventional and hybrid units operating on comparable routes. The average fuel saving of hybrid buses is $20 \%-25 \%$ compared to conventional buses. Differences between cities are basically due to bus types and brands, driving conditions of cities, and different hybrid systems.

While hybrid vehicles do have important energy savings, they still operate with fossil fuel engines and can only reduce $20 \%-30 \%$ of emissions. Hybrids today can already be financially profitable for high-mileage vehicles. However, hybrids are largely conceived as an intermediate technology toward full electrification.

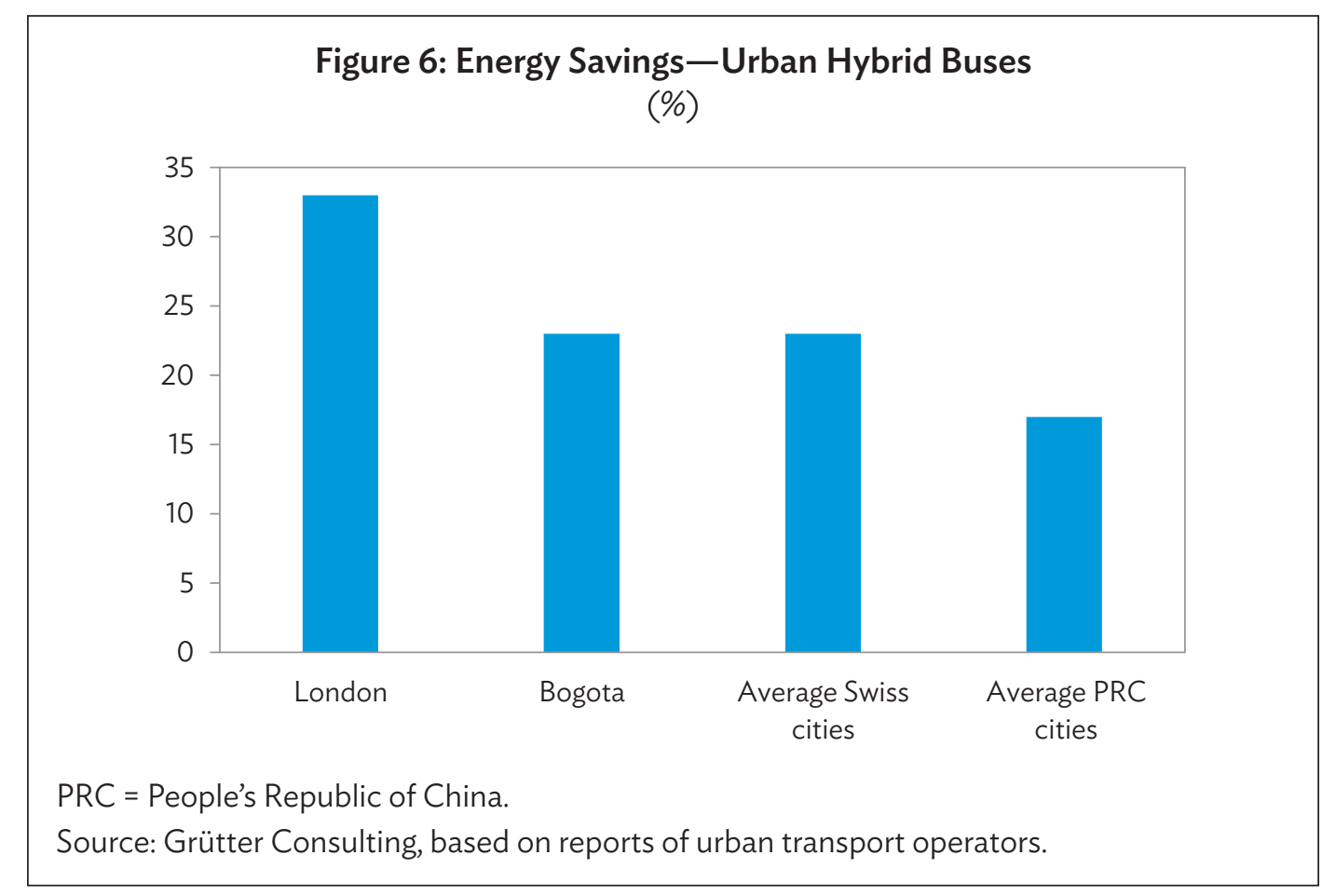

9 EPA. 2016. Light-Duty Automotive Technology, Carbon Dioxide Emissions, and Fuel Economy Trends: 1975 Through 2016.

10 The most popular hybrid car (Toyota Prius) was excluded in the study due to lack of a comparable non-hybrid vehicle; Vincentric. Hybrid Analysis. https://vincentric.com/Home/Industry-Reports/Hybrid-Analysis-October-2014. 


\section{Plug-in Hybrid Electric Vehicles}

Plug-in hybrid electric vehicles (PHEVs) are vehicles with a larger battery than HEVs and can be plugged in to recharge the vehicle battery. The fuel savings and emission reductions from PHEVs are largely dependent on the percentage of annual mileage driven in electric mode, which again is partially dependent on how frequently PHEVs are plugged in. For passenger cars, studies conducted to determine the total share of mileage in electric mode show huge variations with a 2015 Netherlands Organization for Applied Scientific Research (TNO) study in the Netherlands showing as little as 20\%-30\% of total mileage in electric mode while other studies performed in Norway (by the Institute of Transport Economics in 2016), Germany (by the Fraunhofer Institute for Systems Innovation Research in 2014), and the $U$ showed $70 \%-80 \%$ of total mileage in electric mode. ${ }^{11}$ A recent ADB study conducted in 18 cities in the People's Republic of China (PRC) with a plug-in hybrid bus fleet of more than 10,000 units revealed that plug-in hybrid buses are not regularly recharged from the grid. ${ }^{12}$ Average fuel savings of plug-in hybrids are identical to same-size conventional hybrids in every city. Plug-in hybrid buses are not plugged in as they are equipped with a small battery size, typically 25 kilowatt-hour (kWh) for a 12-meter ( $m$ ) bus, which reduces the advantage of recharging, operational complexities in recharging buses, and limited energy cost savings. Bus operators purchase plug-in hybrids instead of conventional hybrids due to plug-in hybrids being heavily subsidized while subsidies for conventional hybrids were phased out. In conclusion, the actual impact and cost-effectiveness of PHEVs is therefore difficult to estimate.

\section{Battery Electric Vehicles}

$\mathrm{BEV}$ s are full EVs including a battery or capacitor as well as an electric engine. A wide array of different vehicle technologies exists, e.g., in the case of electric buses, from electric trolleybuses to opportunity charge and battery electric buses (BEBs). The following chapter will further detail core components of BEVs.

\section{Fuel Cell Electric Vehicles}

Like conventional batteries, fuel cells are electrochemical devices that generate electricity directly by separating positive and negative charges. A fuel cell electric vehicle (FCEV) uses a hydrogen fuel cell as the power source for the drive wheels, sometimes augmented with batteries or a super capacitor. Like $B E V s$, these vehicles have zero tailpipe emissions, but potentially emissions from the production and distribution of hydrogen.

Hydrogen can be produced from various sources, including fossil fuels, biomass, and electrolysis of water with electricity. The environmental impact and energy efficiency of hydrogen depends on how it is produced. The most common forms are:

- Natural gas reforming. Synthesis gas, a mixture of hydrogen, carbon monoxide, and a small amount of carbon dioxide, is created by reacting natural gas with steam at a high temperature. Carbon monoxide is reacted with water to produce additional hydrogen. This method is the cheapest, most efficient, and most common.

- Electrolysis. An electric current divides water into hydrogen and oxygen. Power-to-hydrogen projects are taking off, where excess available renewable electricity is used to make hydrogen

11 European Climate Foundation. 2018. Low-Carbon Cars in Europe: A Socio-Economic Assessment.

12 Grütter Consulting. 2018a. Low Carbon Buses in PRC. 
through electrolysis. Typically, in electrolysis around $50 \mathrm{kWh}$ of electricity are required to produce $1 \mathrm{~kg}$ of hydrogen. ${ }^{13}$

From the production process, it is obvious that FCEV will have potentially significant upstream emissions. If hydrogen is produced from natural gas, then GHG emissions will be comparable or higher compared to ICEs. If produced through electrolysis, indirect emissions depend on the carbon factor of the grid. The large amount of electricity used for production of hydrogen will, however, result in a significantly higher energy usage and therefore higher emissions of FCEVs compared to BEVs. The marginal market penetration of FCEVs, ${ }^{14}$ the potentially fossil energy source as well as the high electricity usage if produced with electrolysis, constitute the factors why FCEVs are not included in this report.

\section{Energy Usage for Different Vehicle Technologies}

Energy usage differs greatly between different vehicle technologies. The following graph compares energy usage for different power trains based on a standard urban 12-m bus. Natural gas units have the

Figure 7: Energy Usage-Standard Urban 12-Meter Bus

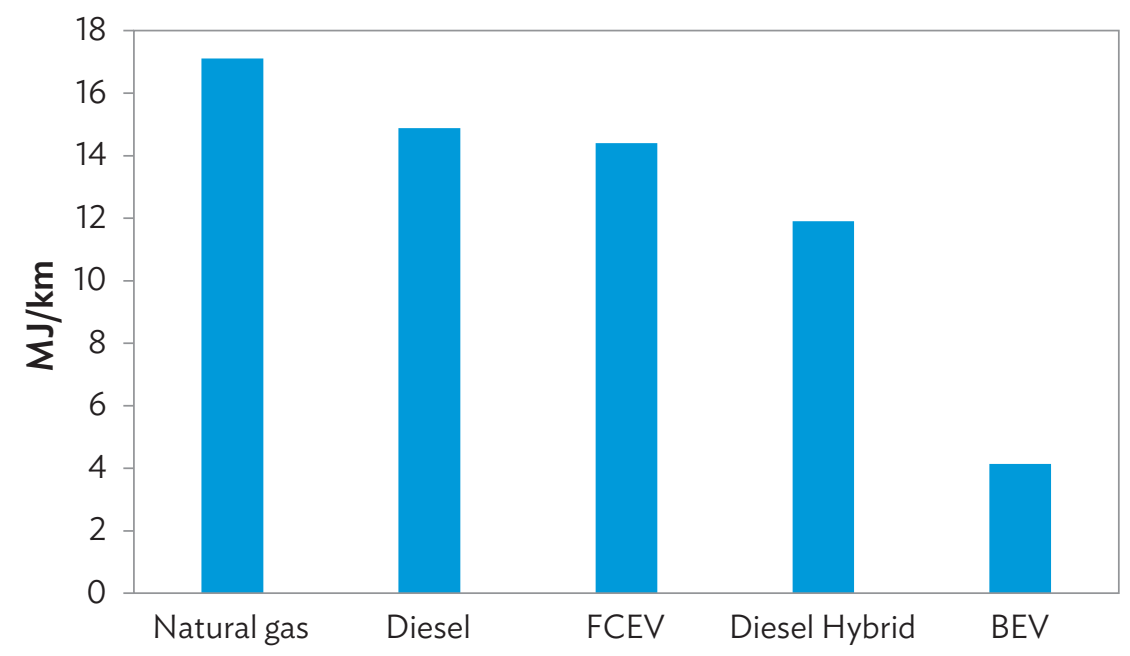

$\mathrm{BEV}=$ battery electric vehicle, $\mathrm{CHIC}=$ Clean Hydrogen in European Cities, EEA = European Environmental Agency, FCEV = fuel cell electric vehicle, ICCT = International Council on Clean Transportation, $\mathrm{km}=$ kilometer, $\mathrm{kWh} / \mathrm{km}=$ kilowatt-hour per kilometer, NREL = National Renewable Energy Laboratory, PSI = Paul Scherrer Institut, PRC = People's Republic of China.

Notes: Diesel bus based on Euro 6, 41 liter per 100 km (EEA, 2016a, COPERT Tier 3 with 18 km per hour, 0\% gradient, $50 \%$ load factor); natural gas, 15\% more energy usage than diesel (Grütter Consulting, 2018a, average PRC cities, 17\%; ICCT, 2015, 15\%; NREL cited in MJB\&A, 2012, 9\%); hybrid fuel savings, see above; BEV Grütter Consulting, 2018a average PRC cities 1.14 kWh/km; Foothill transit, NREL, 2017 with 12 units $1.3 \mathrm{kWh} /$ km; FCEV 8 kilograms hydrogen per 100 km, based on CHIC, 2016 and PSI, 2016, for electricity consumption to produce hydrogen.

Source: ADB. 2018. Sustainable Transport Solutions: Low-Carbon Buses in the People's Republic of China. Manila.

13 PSI. 2016. Trends und Potenziale der Brennstoffzellen-Entwicklung.

14 In total, NREL estimates for example that no more than 300 hydrogen buses operate worldwide, most of which are buses of up to $12 \mathrm{~m}$ and few larger units; NREL. Fuel Cell Electric Bus Evaluations. https://www.nrel.gov/hydrogen/fuel-cell-busevaluation.html (accessed 18 October 2018); Airqualitynews.com. 2016. London Mayor unveils hydrogen-powered double decker bus. 1 December. http://airqualitynews.com/2016/12/01/london-mayor-hydrogen-double-decker-bus/. 
highest energy usage followed by diesel and fuel cell buses. Hybrid buses use around 20\% less energy than comparable same-fuel units. Electric buses use around one-fourth of the energy used by other power trains, showing clearly the high energy efficiency of electric traction.

\subsection{Electric Vehicle Components}

\subsubsection{Battery Set and Charging System}

Core components of EVs are the power train, the battery, and the charging system. The battery set is obviously a key component for the electric vehicle range. However, different mixtures of charging systems and battery packs can be chosen including direct overhead charging, opportunity fast and ultrafast charging, slow and fast charging, and battery-swap. The charging system and battery set configuration have large technical and financial implications. The following table summarizes the advantages and disadvantages of different charging technologies. ${ }^{15}$

Table 2: Charging Systems and Battery Packs

\begin{tabular}{|c|c|c|c|}
\hline Charging System & Advantages & Disadvantages & Comments \\
\hline Overhead wiring & $\begin{array}{l}\text { Minimum battery amount on } \\
\text { vehicle, thus reducing vehicle } \\
\text { weight, space required for } \\
\text { batteries, and vehicle cost; } \\
\text { simple battery management } \\
\text { system. }\end{array}$ & $\begin{array}{l}\text { High infrastructure cost and limited route } \\
\text { flexibility, electricity cost can be higher } \\
\text { due to peak and off-peak day electricity } \\
\text { consumption, high power requirements on } \\
\text { the electric grid and high demand charge. }\end{array}$ & $\begin{array}{l}\text { Basically, used for } \\
\text { trolleybuses; however, } \\
\text { also under discussion } \\
\text { for trucks. }\end{array}$ \\
\hline $\begin{array}{l}\text { Opportunity } \\
\text { charging, } \\
\text { including ultrafast } \\
\text { charging }\end{array}$ & $\begin{array}{l}\text { Small to minimum battery } \\
\text { amount on vehicle, thus } \\
\text { reducing vehicle weight, } \\
\text { space required for batteries, } \\
\text { and vehicle cost. }\end{array}$ & $\begin{array}{l}\text { High infrastructure cost and limited route } \\
\text { flexibility; electricity cost can be higher } \\
\text { due to peak and off-peak day electricity } \\
\text { consumption; high power requirements on } \\
\text { the electric grid; and high demand charge, } \\
\text { but this can eventually be avoided with peak } \\
\text { shaving. }\end{array}$ & $\begin{array}{l}\text { Basically, used for } \\
\text { buses, but also under } \\
\text { discussion for trucks. }\end{array}$ \\
\hline Fast charging & $\begin{array}{l}\text { Increased vehicle range with } \\
\text { lower battery quantity, thus } \\
\text { reducing vehicle weight and } \\
\text { cost. }\end{array}$ & $\begin{array}{l}\text { Increased investment in chargers, higher } \\
\text { consumption charges due to usage of peak } \\
\text { electricity, power charge can be very high } \\
\text { if only a small number of vehicles use the } \\
\text { chargers. }\end{array}$ & $\begin{array}{l}\text { Used for all types of } \\
\text { vehicles. }\end{array}$ \\
\hline $\begin{array}{l}\text { Slow overnight } \\
\text { charging }\end{array}$ & $\begin{array}{l}\text { Minimum investment in } \\
\text { charging, simple to manage, } \\
\text { consumption of low-cost } \\
\text { night electricity. }\end{array}$ & $\begin{array}{l}\text { If this is the only charging approach used, } \\
\text { then the vehicle will require a large battery } \\
\text { set for a sufficient driving range making the } \\
\text { vehicle costly and heavy. }\end{array}$ & $\begin{array}{l}\text { Used for all types of } \\
\text { vehicles; often slow } \\
\text { and fast charging are } \\
\text { combined. }\end{array}$ \\
\hline Battery-swap & $\begin{array}{l}\text { Smaller battery packs on the } \\
\text { vehicle if sufficient battery- } \\
\text { swap stations are available } \\
\text { nearby. }\end{array}$ & $\begin{array}{l}\text { Requires costly infrastructure and a larger } \\
\text { amount of batteries, limited flexibility as } \\
\text { battery swap systems are often tied to certain } \\
\text { vehicle brands. }\end{array}$ & $\begin{array}{l}\text { Used for all types of } \\
\text { vehicles, but trend is to } \\
\text { use it only for 2- and } \\
\text { 3-wheelers. }\end{array}$ \\
\hline
\end{tabular}

a A demand charge is a fee based on the highest rate, measured in kilowatts ( $\mathrm{kW}$ ), at which electricity is drawn during any $15-$ to 30-minute interval in the monthly billing period. This is separate from the charge paid for the actual energy consumed, which is measured in kilowatt-hours.

b On-site batteries can charge and discharge using direct current (DC) and connect to the grid through a large inverter. They can then charge from the grid at times when costs are lower, store the power, and release it when demand is higher. Through this they can also level out the power demand posed on the grid and reduce the demand charge.

Source: Grütter Consulting.

15 See also Chapter 9.2. for a discussion of charging systems for buses. 
Table 3: Typical Battery Sizes per Electric Vehicle Category

\begin{tabular}{|c|c|c|}
\hline Vehicle Category & Typical Battery Size & Comment \\
\hline Motorcycles & $1.5-4 \mathrm{kWh}$ & $\begin{array}{l}\text { The most common are low-powered electric scooters with a smaller } \\
\text { battery set }\end{array}$ \\
\hline 3-wheelers & $2-6 \mathrm{kWh}$ & Dependent on carrying capacity \\
\hline Passenger cars & 20-100 kWh & $\begin{array}{l}\text { The three best-selling PRC-made EVs having a size between } 18-23 \mathrm{kWh} \\
\text { (mainly small vehicles with design focus on affordability) while midsized } \\
\text { e-cars in Europe and North America have larger battery capacities ranging } \\
\text { from } 20-60 \mathrm{kWh} \text { and SUVs from } 75-100 \mathrm{kWh}^{\mathrm{a}}\end{array}$ \\
\hline Urban $12-m$ buses & 100-350 kWh & $\begin{array}{l}\text { Average values in PRC for } 6-\mathrm{m} \text { BEBs } 60 \mathrm{kWh} \text {, for } 8-\mathrm{m} \text { BEBs } 120 \mathrm{kWh} \text {, and } \\
\text { for } 12-\mathrm{m} \text { BEBs } 210 \mathrm{kWh} \text {; fast charged or opportunity charged buses have a } \\
\text { lower battery pack and slow charged units have a larger battery pack. }\end{array}$ \\
\hline $3.5-7$ ton truck & $20-80 \mathrm{kWh}$ & Dependent on load capacity of truck. \\
\hline
\end{tabular}

$\mathrm{BEB}=$ battery electric bus, $\mathrm{EV}=$ electric vehicle, $\mathrm{kWh}=$ kilowatt-hour, $\mathrm{m}=$ meter, $\mathrm{PRC}=$ People's Republic of China, $\mathrm{SUV}=$ sports utility vehicle.

a IEA. 2018. Global EV Outlook 2018. Paris.

Typical batteries used currently in EVs are based on the lithium-ion technology, with battery packs for light-duty applications having gravimetric densities of 200 watt-hour per kilogram and volumetric pack energy densities of 200-300 watt-hour per liter. The life span of batteries retaining a state of charge (SOC) of $80 \%$ is compatible today with the expected life span of the car (around 1,000 charging cycles allowing a mileage of around 150,000-200,000 km). For buses, a replacement after around 8 years is required. ${ }^{16}$

Table 3 shows typical battery sizes for different vehicle categories.

\subsubsection{Vehicle Driving Range}

The driving range is an important criterion in purchasing an EV. The client can choose between a large set of battery configurations and charging options especially for trucks and buses. This requires knowledge on how to calculate the potential range of an electric vehicle, i.e., how to determine the battery set required for a required daily driving range. The simplified calculation of battery pack divided by average electricity consumption can be misleading as shown in Figure 8.

While manufacturers claim a driving range of $280 \mathrm{~km}$ with a battery pack of $250 \mathrm{kWh}$, the actual operational range is around $200 \mathrm{~km}$ in year 1 (less during summer months) and can drop to $130 \mathrm{~km}$ in year 8 during summer. This means that the bus might not be able to operate on the routes as expected or will require more frequent recharging during the day, which might not be feasible operationally.

The actual and the theoretically claimed driving range of EVs can be factor 2 apart due to the following:

- The real-world performance of $\mathrm{EVs}$ is, as with fossil fuel vehicles, worse than claimed by manufacturers.

- A reserve ratio of at least $10 \%$ is required as drivers cannot take the risk and drive until 0\% SOC and then no charging station is available. Also, many vehicles have a relatively imprecise SOC indication with potential sudden drops of $10 \%$ of SOC.

16 IEA. 2018b. Global EV Outlook 2018. Paris. 


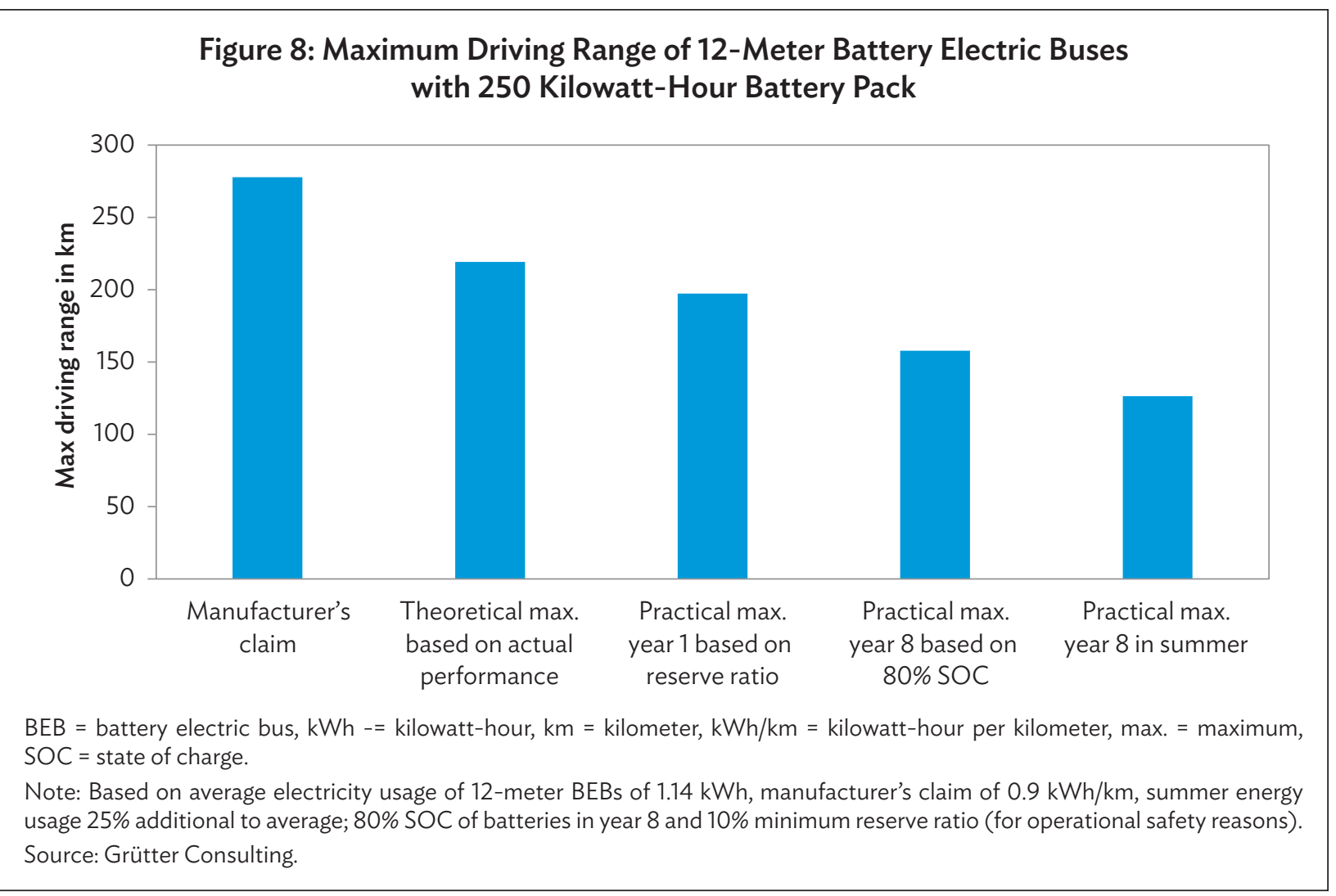

- The SOC of the battery drops over time. Bus manufacturers, as of 2018 , typically guarantee a SOC of $80 \%$ in year 8 , i.e., the bus will only have $80 \%$ of the driving range even if batteries are fully loaded.

- EVs use significantly more energy when air-conditioning or heating is turned on or under extreme driving conditions (e.g., steep gradients, high speed). Energy usage with a fully turned on air-conditioning can increase by $50 \%$.

\section{THE ELECTRIC VEHICLE MARKET}

\subsection{Global Outlook}

\section{Passenger Cars}

By 2017, 3 million electric and plug-in hybrid passenger cars were plying the world's roads. EV sales are increasing worldwide, but are still disproportionally concentrated in few countries. The global electric car stock currently corresponds to just $0.2 \%$ of the total number of passenger cars in circulation. ${ }^{17}$

17 IEA. 2017b. Global EV Outlook 2017. Paris. 
Figure 9: Battery Electric Passenger Car Stock, 2013-2017
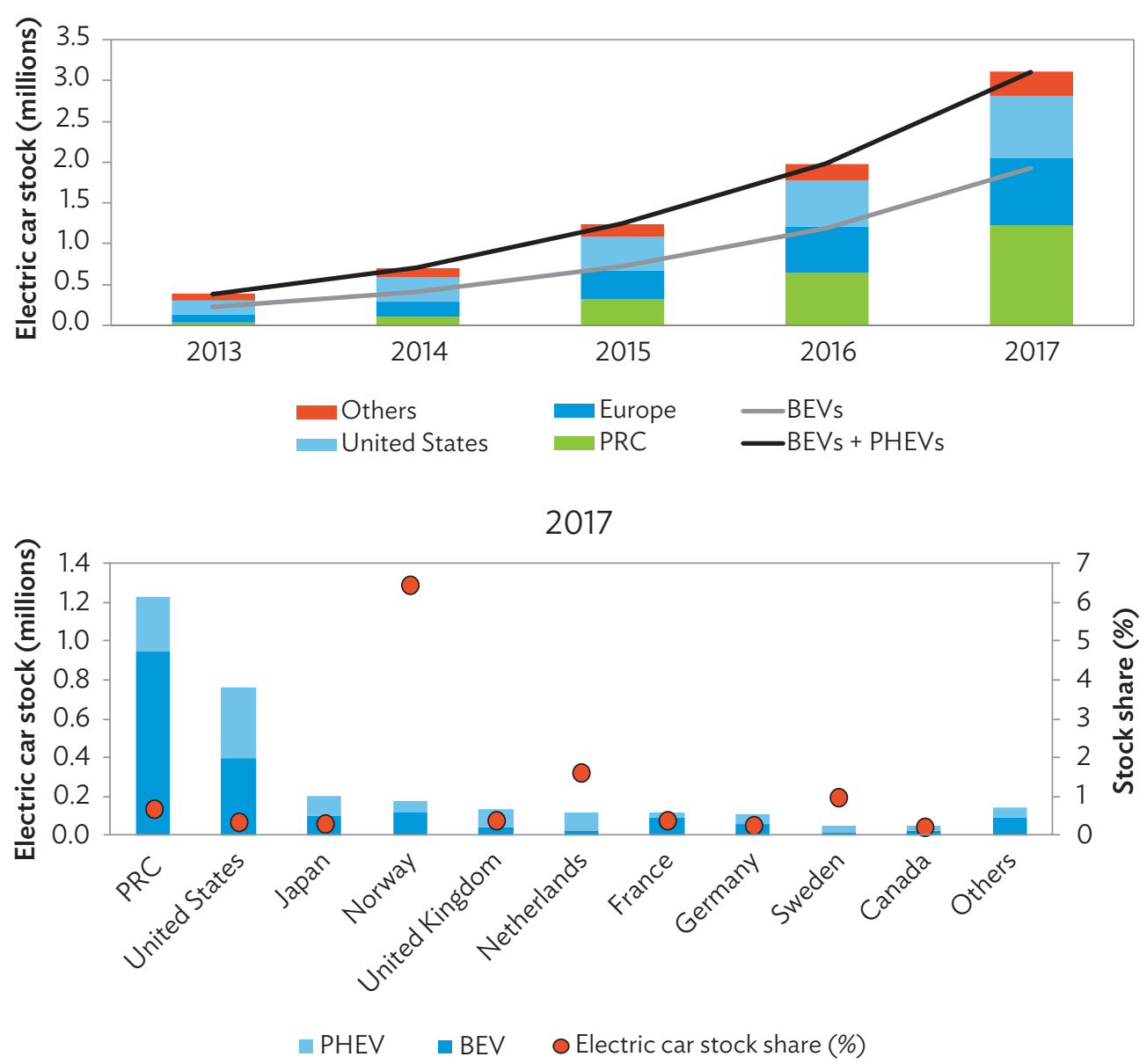

$\mathrm{BEV}$ s = battery electric vehicle, $\mathrm{PHEVs}=$ plug-in hybrid electric vehicle, $\mathrm{PRC}=$ People's Republic of China.

Note: Stock shares are calculated based on country submissions and estimates of the rolling vehicle stocks developed for the International Energy Agency (IEA) Mobility Model. The vehicle stocks are estimated based on new vehicle registration data, lifetime range of 13-18 years, and vehicle scrappage using a survival curve that declines linearly in the last 5 years of the active vehicle life. Lifetimes at the low end of the range are used for countries with higher income levels (and vice versa).

Source: IEA. 2018b.

EV passenger car sales surpassed 1 million units for the first time in 2017. By 2020, it is projected that 4.5 million EVs could be sold, i.e., around $5 \%$ of the global passenger car sales and by 2030, this figure could reach $20 \%$ of global vehicle sales (35\% in Europe). ${ }^{18}$

The growth is concentrated in few countries with more than $50 \%$ of all electric cars sold worldwide in 2016 in the People's Republic of China (PRC), and, in 2017, the PRC was expected to become a bigger market for BEVs market than the United States and Europe combined. Of all electric cars sold, $80 \%$ are just in three countries: the PRC, Norway, and the US.

18 McKinsey. 2018a. The Global Electric-Vehicle Market Is Amped Up and on the Rise. 
Asian countries with a sizable pure electric car stock in 2017 are the PRC with 950,000 units (470,000 additional units in 2017), Japan with 104,000 units (18,000 additional units in 2017), and the Republic of Korea with 24,000 units (13,000 additional units in 2017). India had an EV stock in 2017 of 7,000 units (2,000 more than 2016) and Thailand had $800 \mathrm{EVs}$ (300 more than 2016). ${ }^{19}$

The share of new sold BEVs and plug-in hybrid electric vehicles (PHEVs) is by far the highest in Norway with $39 \%$ of new car sales in 2017, followed by Iceland with $12 \%$, and Sweden with $6 \% .^{20}$ The market share of new sold EVs in 2017 in the PRC was 1.8\%, in the Republic of Korea 1.1\%, in Japan 0.3\%, and in India $0.06 \%$. Worldwide, the $\mathrm{EV}$ share of new sold vehicles is $0.5 \%{ }^{21}$

EV sales are not only focused on certain countries, but also concentrated in few metropolitan areas, with just 20 cities accounting for around $40 \%$ of the world's electric passenger cars. This includes various PRC cities (notably Qingdao with 11\% of new passenger car sales in 2016 as pure electric, and similarly Beijing with a share of $8 \%$ ); some European cities (notably Oslo with a share of 33\% of pure electric and plug-in new passenger car sales in 2016, of which the majority are pure electric); and few US cities (notably San Jose with a 10\% share of new car sales in 2016, including pure electric and plug-ins).

The development of electric cars in Norway is especially impressive. Electric car numbers have jumped within 1 decade from zero to more than 100,000 units in 2017 (Figure 10). Additionally, another 60,000 PHEVs were plying the streets of Norway in 2017. In 2017, there were 33,000 pure electric cars and another 29,000 PHEVs sold in Norway. Pure electric cars accounted for $21 \%$ of car sales while pure electric cars plus PHEVs accounted for $39 \%$ of car sales in $2017 .{ }^{22}$ Norway has nearly 10,000 publicly

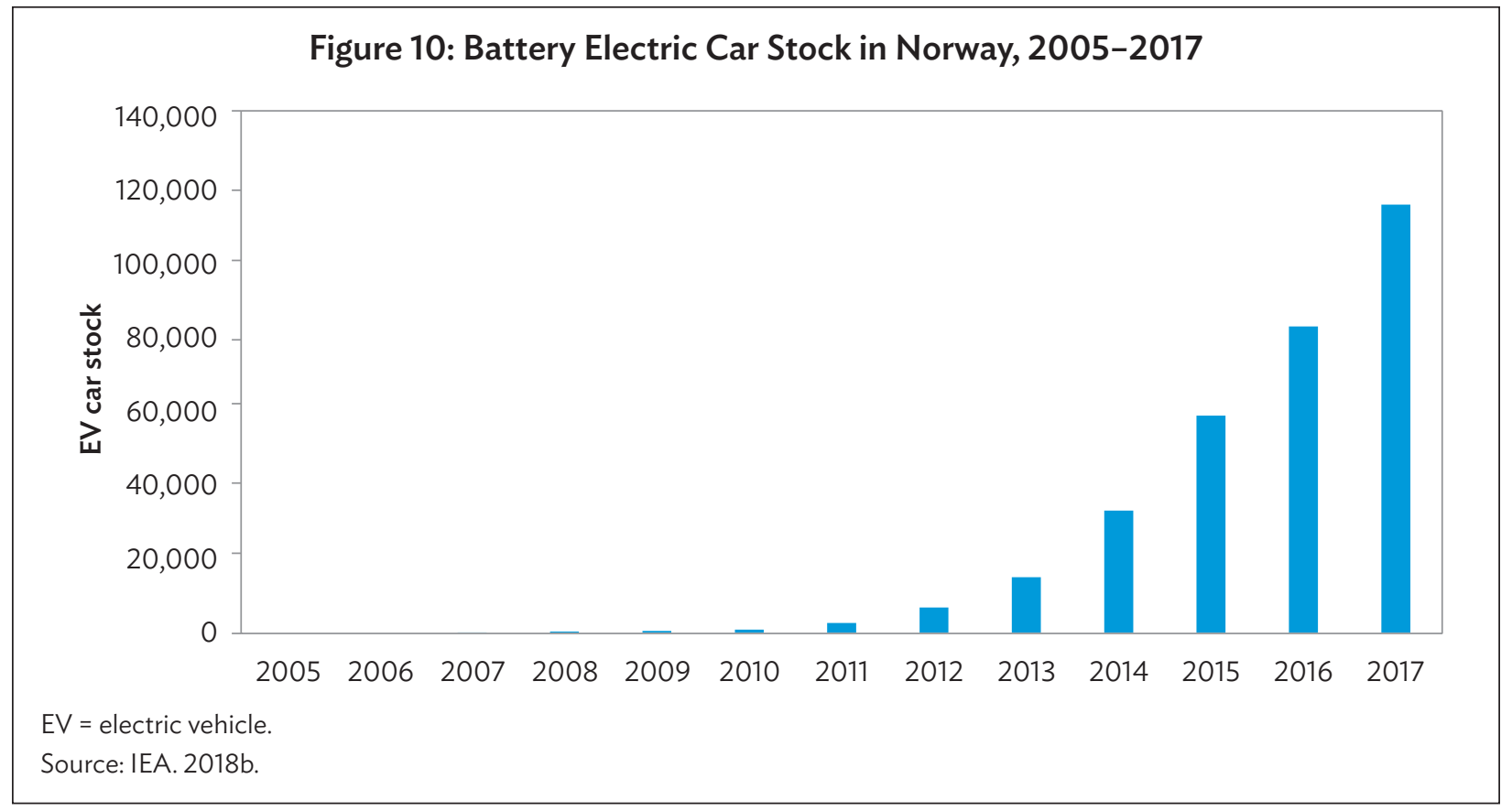

\footnotetext{
19 IEA. 2018b. Global EV Outlook 2018. Paris.

20 IEA. 2018b. Global EV Outlook 2018. Paris.

21 IEA. 2018b. Global EV Outlook 2018. Paris.

22 IEA. 2018a. Nordic EV Outlook 2018. Paris.
} 
Figure 11: Electric Vehicle Market Adoption

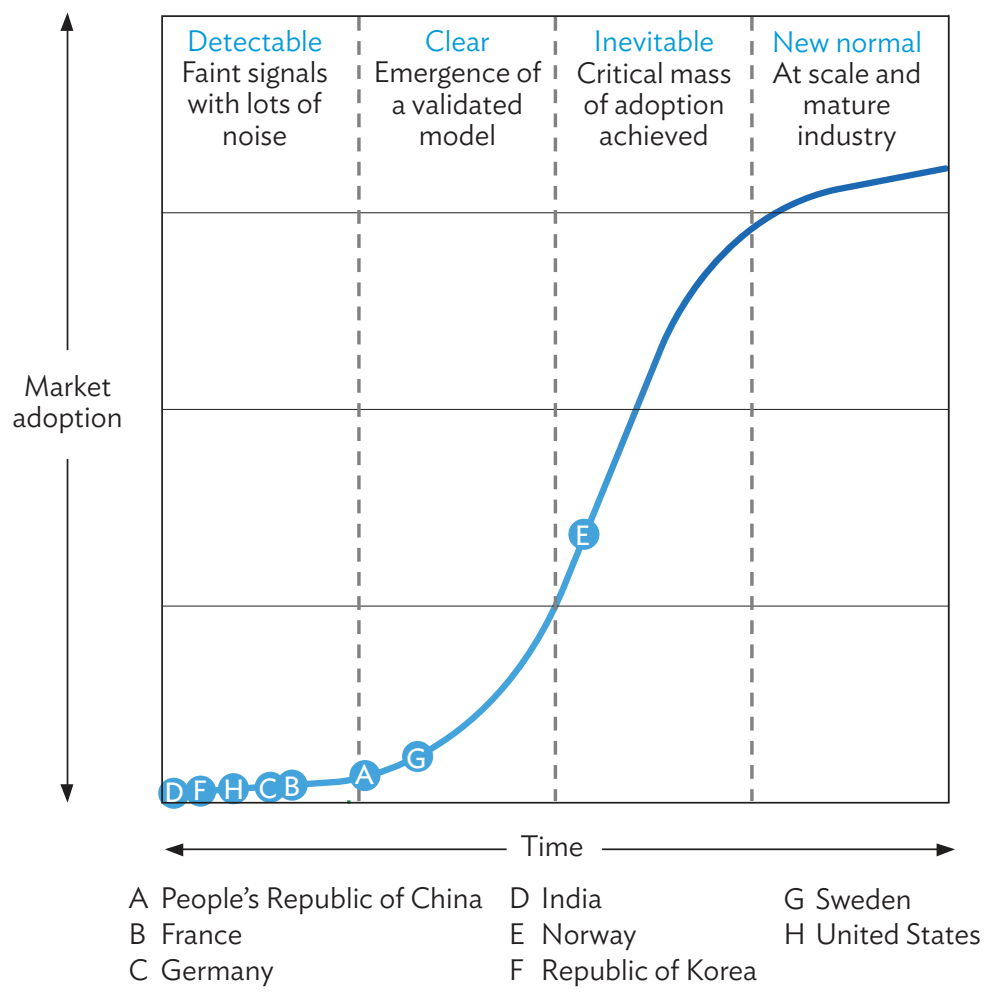

Source: McKinsey. 2018a.

accessible chargers (of which around 13\% are fast chargers), or a ratio of 19 electric cars (including PHEVs) per public charger.

In Norway-which is clearly ahead of other countries-a critical mass of adoption has been achieved (Figure 11).

In 2017, around 3 million chargers had been installed, of which around 330,000 units were publicly available slow or fast chargers (two-thirds slow chargers and one-third fast chargers). ${ }^{23}$ Publicly accessible infrastructure, especially fast chargers, is growing rapidly. The number of charging facilities, especially fast charge facilities, is an important issue as concerns about charging facilities are among the main reasons why consumers do not purchase EVs (Figure 12).

A similar study in Germany and the US had as main reasons the price (25\%), followed by the driving range (24\%), and the charging infrastructure (18\%). Interestingly, a large gap exists between perceived and real-world "range anxiety" and charging, i.e., today's EV owners are more satisfied with EV driving range and charging infrastructure than potential buyers. ${ }^{24}$ Another study conducted in 2017 also confirmed

23 IEA. 2018b. Global EV Outlook 2018. Paris; fast chargers include AC 43 kW chargers, DC chargers, Tesla Superchargers, and inductive chargers.

24 McKinsey. 2017a. Electrifying Insights: How Automakers Can Drive Electrified Vehicle Sales and Profitability. 


\section{Figure 12: Reasons for Not Purchasing Electric Vehicles in the People's Republic of China}

Concerned about the scarcity of charging locations

Price is too high

Worried about technical failure

Charging speed is too slow

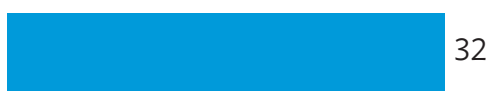

20

19

Source: McKinsey. 2016.

Figure 13: Key Concerns of Consumers of Electric Vehicles

(\%)

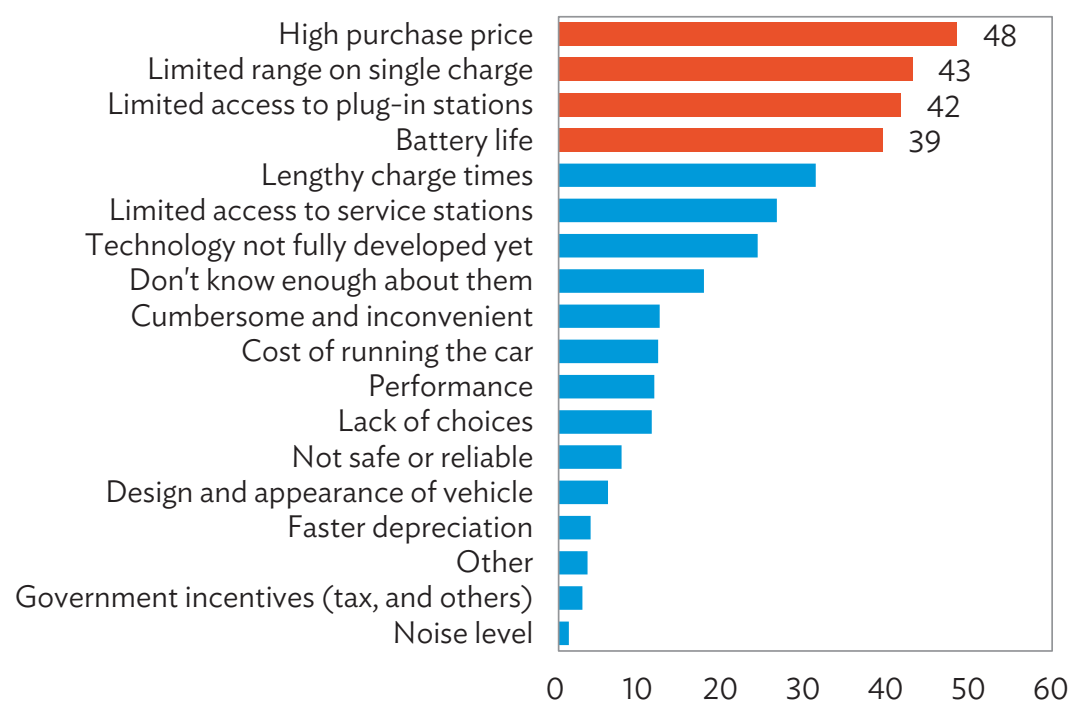

Source: UBS. 2017.

that the purchase price, the limited range, the limited access to charging stations, and the battery life are the major concerns for potential buyers of EVs.

\section{Electric 2- and 3-Wheelers}

The PRC dominates the electric 2-wheeler market with around 26 million units sold in 2016 and a vehicle stock estimated at 200 million to 230 million units. ${ }^{25}$ This represents around $40 \%$ of the world's total

25 IEA. 2017b. Global EV Outlook 2017. Paris; total two-wheeler sales worldwide in 2017 around 30 million (IEA. 2018b. Global EV Outlook 2018. Paris.). 


\section{Figure 14: Projected Share of 2-Wheelers in Major Asian Regions and the Organisation for Economic Co-operation and Development}

$(\%)$

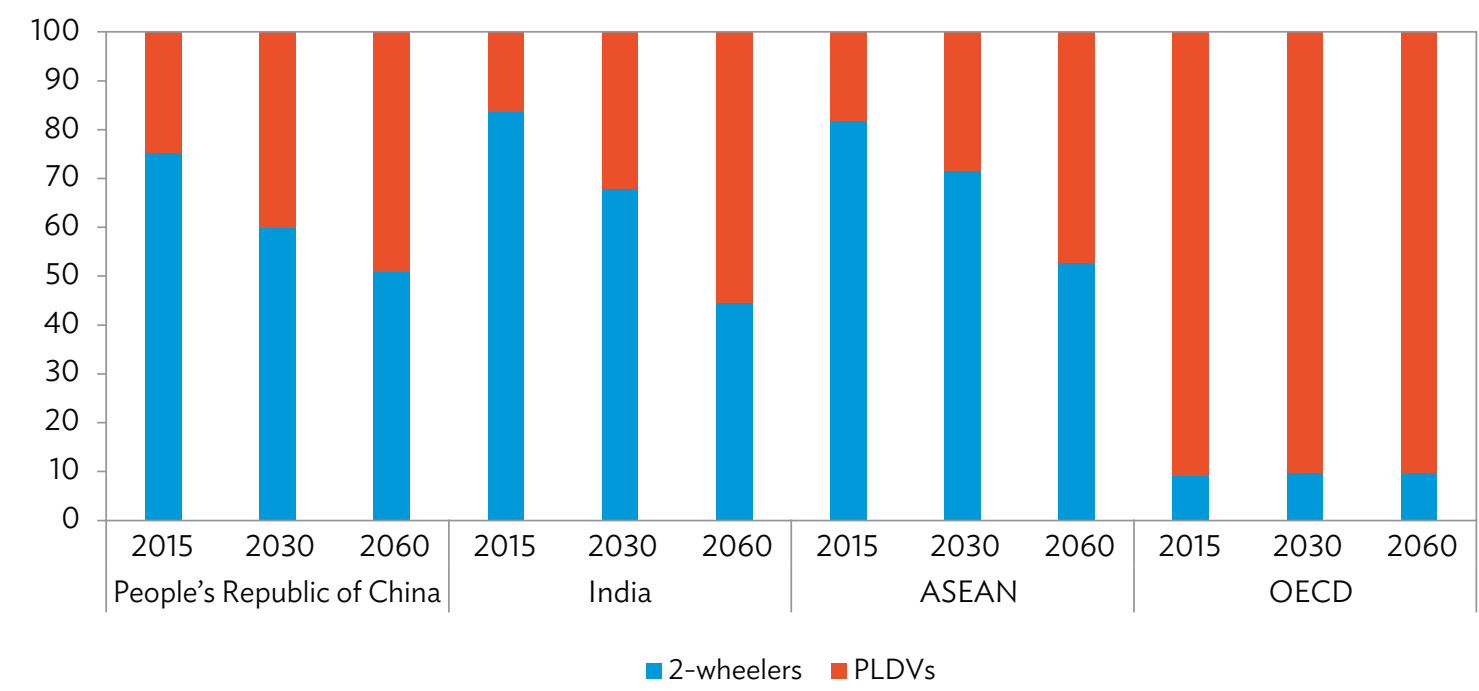

ASEAN = Association of Southeast Asian Nations, OECD = Organisation for Economic Co-Operation and Development, PLDV = passenger light-duty vehicles.

Source: IEA. 2017a. Energy Technology Perspective 2017 - Catalysing Energy Technology Transformations. Paris.

two-wheeler fleet. While the PRC's share of 2-wheelers is expected to drop in the future, it still accounts for a massive share of vehicle stock as well as vehicles sold in most Asian countries (Figure 14).

In many countries, electric 2- and 3-wheelers are not registered, so official data is difficult to obtain. However, large fleets of such vehicles have been reported in Bangladesh (especially 3-wheelers), India, Nepal, and Viet Nam. Electric 2- and 3-wheelers are also quite straightforward to decarbonize due to low weight, short range, and the high efficiency of electric motors.

\section{Electric Buses}

In 2017, there were around 385,000 electric buses ${ }^{26}$ on the roads worldwide, with $99 \%$ of the total located in PRC. ${ }^{27}$ E-buses in the PRC made up around $17 \%$ of the total bus fleet and $22 \%$ of new bus sales in 2017 (Figure 15), with many cities going for electric bus fleets within the next few years. Bloomberg NEF projects that battery electric bus (BEB) deployment will increase by three times until 2025 and reach 1.2 million units, with the large majority being operated in the PRC. Apart from BEBs, electric trolleybuses are used in many Asian countries including Armenia, Kazakhstan, Mongolia, and the PRC. ${ }^{28}$

The PRC also dominates the BEB manufacturing market with Yutong (the market leader with 19\%), BYD, Zhontong, and Jinlong having a combined market share of 50\% in 2016. ${ }^{29}$ Outside PRC, less than

26 Includes pure electric buses and plug-in hybrids.

27 Bloomberg New Energy Finance. 2018. Electric Buses in Cities.

28 Trolleybus. World Trolleybus Systems. http://www.tbus.org.uk/systems.htm.

29 Bloomberg New Energy Finance. 2018. Electric Buses in Cities. 


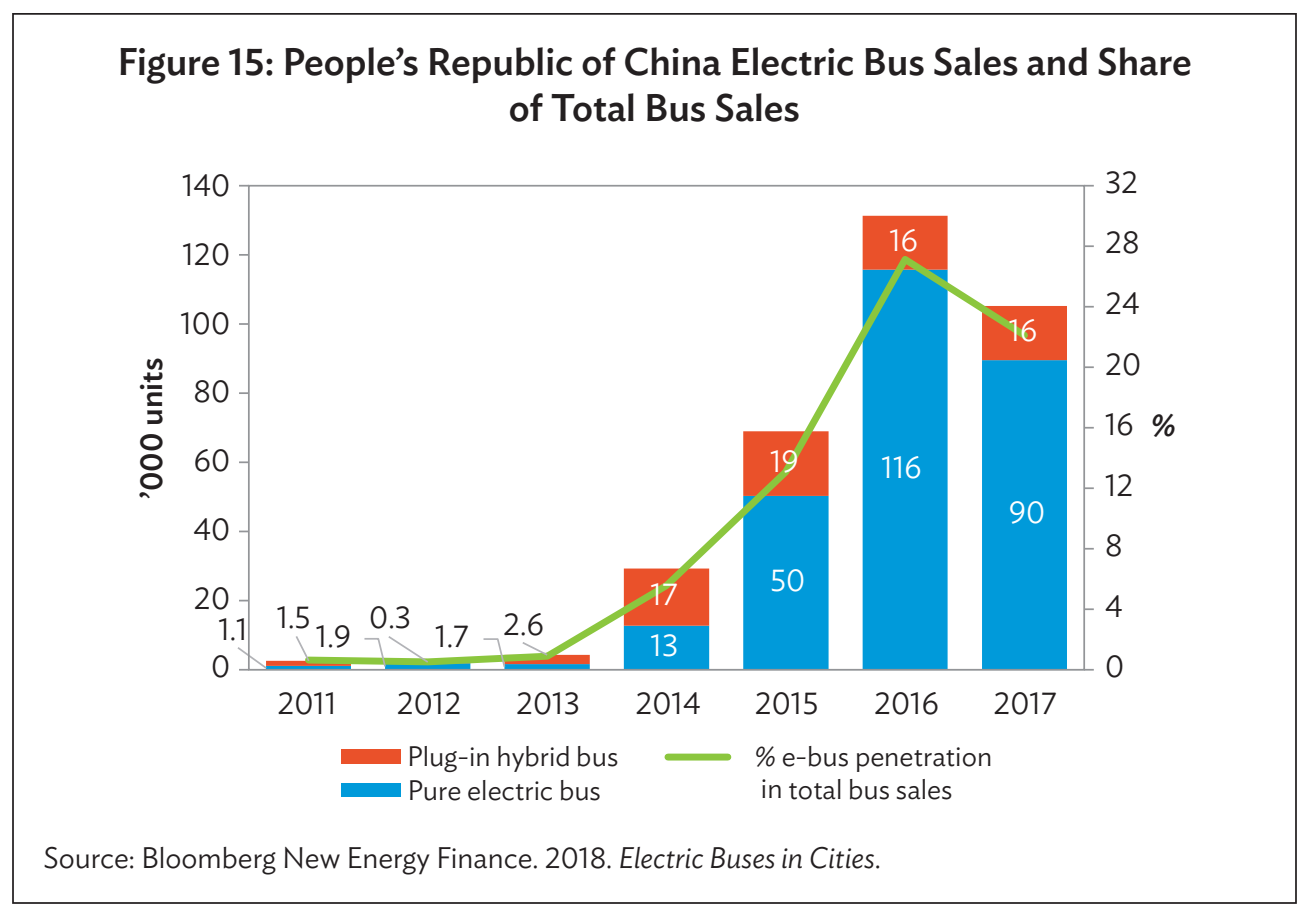

2,000 BEBs were operating as of 2017. ${ }^{30}$ However, this is expected to change rapidly in the next few years with many cities worldwide gearing up for electric buses. In Europe, for example, the International Association of Public Transport estimates that the market share of urban electric buses will be more than $50 \%$ by 2030 (Figure 16).

\section{Electric Trucks}

Total cost of ownership (TCO) plays a more important role in the purchase of commercial vehicles than for passenger cars. It is expected that especially for light- and medium-duty trucks, TCO parity with diesel units will be reached in the next decade. With improved model availability, tightening of regulations especially in urban zones, and an established charging infrastructure, it is expected that after 2025 light- and medium-duty electric trucks could start to penetrate the market increasingly (followed by heavy-duty trucks). ${ }^{31}$ However, $75 \%$ of freight truck greenhouse gas (GHG) emissions are from heavy-duty trucks (Figure 17).

\subsection{Electric Vehicle Market in ADB Developing Member Countries}

\section{People's Republic of China ${ }^{32}$}

As of 2017, the PRC had around 200 million electric 2-wheelers, around 1 million electric cars, and 380,000 e-buses plying its streets. In all vehicle categories, the PRC has in absolute terms by far the

30 The number of electric buses including trolleybuses was however much larger; in Switzerland alone around 550 electric trolleybuses (10\% of the bus fleet) are operating (see Federal Office for Statistics. Road vehicles - stock, degree of motorisation. https://www.bfs.admin.ch/bfs/de/home/statistiken/mobilitaet-verkehr/verkehrsinfrastruktur-fahrzeuge/ fahrzeuge/strassenfahrzeuge-bestand-motorisierungsgrad.html [accessed 18 October 2018]).

31 McKinsey. 2017b. What's Sparking Electric-Vehicle Adoption in the Truck Industry?

32 See previous chapter for data sources. 
Figure 16: Projected Market Share of Urban Bus Technologies in Europe

(\%)

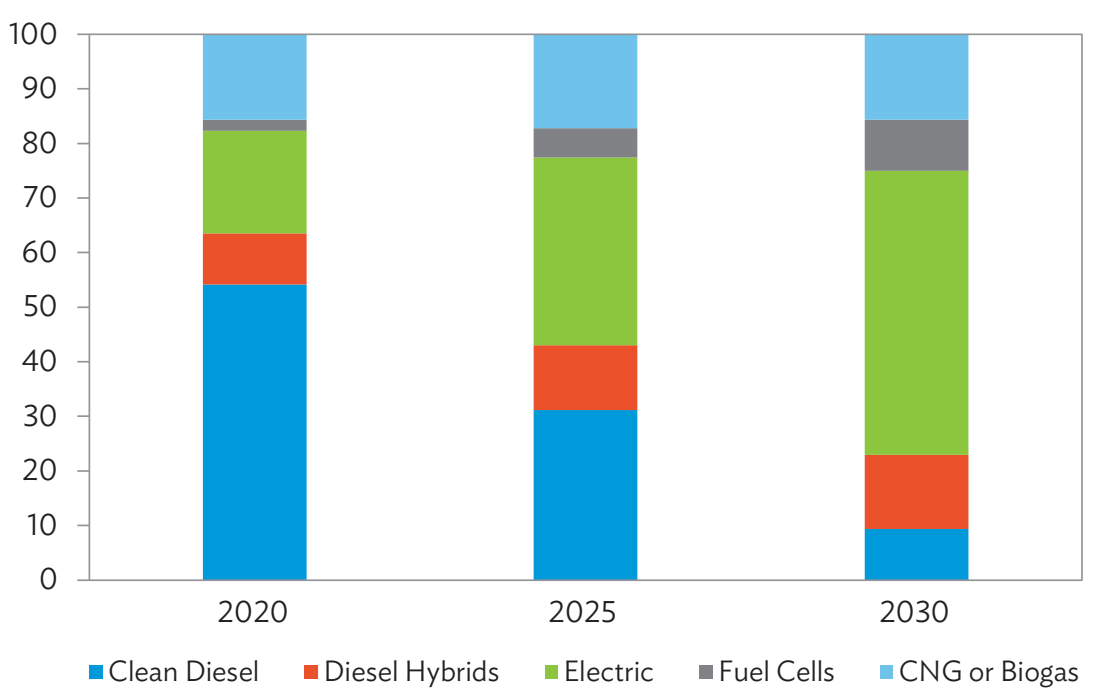

CNG = compressed natural gas.

Source: UITP. 2017. An Electric Solution for Urban Bus Networks. Presentation by P. Bruge, Berlin, 21 September 2017.

\section{Figure 17: Projected Global Freight Activity and Well-to-Wheel} Greenhouse Gas Emissions, 2015-2050

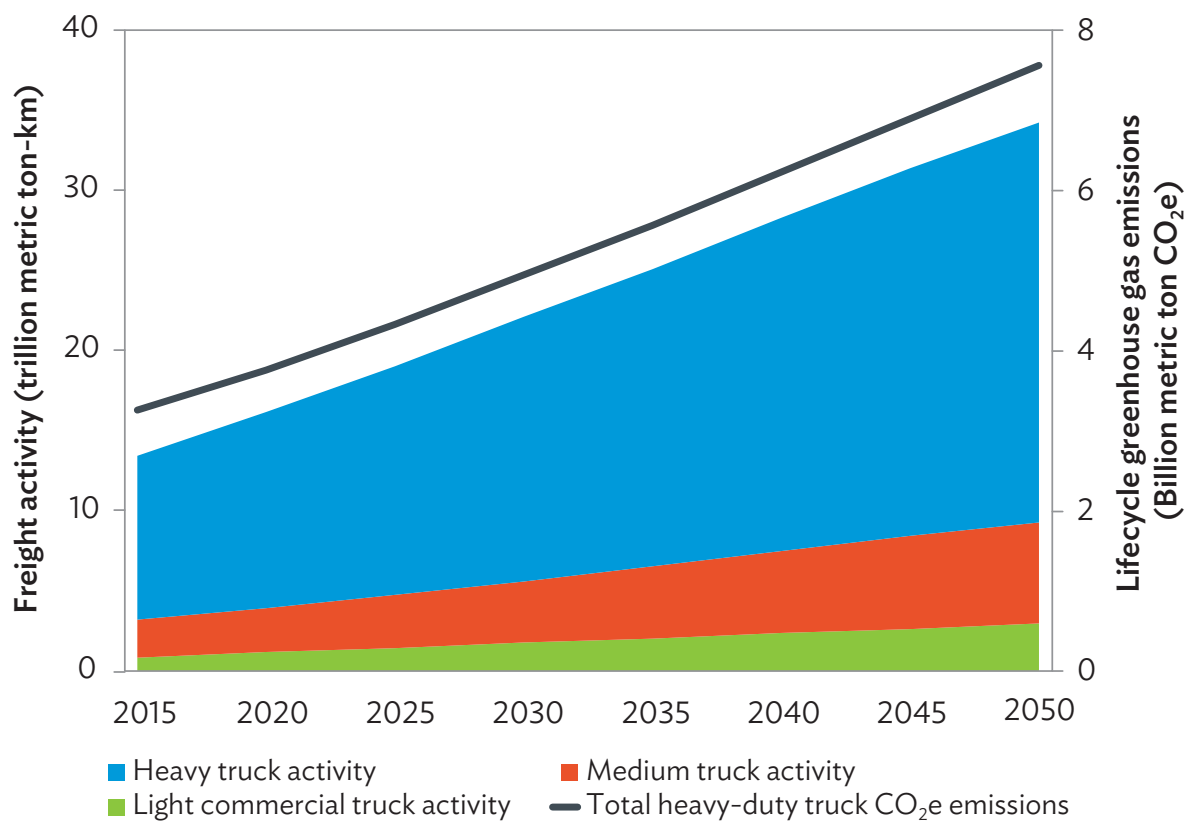

$\mathrm{CO}_{2} \mathrm{e}=$ carbon dioxide equivalent

Source: ICCT. 2017c. Transitioning to Zero-Emission Heavy-Duty Freight Vehicles. 
largest number of EVs deployed. In market share, it has a 1.8\% share of new sold EVs in 2017, making it one of the leading markets for EVs. By the end of 2016, the PRC had 107,000 public EV charging outlets. EV manufacturers from the PRC have more than $40 \%$ of global market share. ${ }^{33}$

Multiple car-sharing and e-hailing companies in the PRC are also using large EV numbers, e.g., Didi claims to operate $260,000 \mathrm{EVs}$ and has launched a charging network to support its drivers; ${ }^{34} \mathrm{CAOCAO}$ has over 12,000 EVs for e-hailing; and car-sharing companies like EVCARD, GOFUN, and others have around 100,000 EVs to offer. ${ }^{35}$

\section{India}

India has significant experience with low-powered electric scooters (e-scooters) as well as recently with electric rickshaws (e-rickshaws) electric rickshaws (e-rickshaws). In Delhi alone, it is estimated that around 100,000 e-rickshaws operate while traffic police only have registered less than 20,000 units (for more details on e-rickshaws in India, see Chapter 10). ${ }^{36}$ No comprehensive official registration numbers exist for low-powered scooters and e-rickshaws, making an assessment of deployed numbers difficult. In the last 8 years, some 450,000 electric motorcycles (e-motorcycles) have been sold in the country. The number of e-motorcycles declined after 2013 due to fewer incentives, but increased again in 2016-2017 with 44,000 new units sold. ${ }^{37}$ Nevertheless, some 17 million motorcycles are annually sold in India; the market sales share of e-motorcycles is still well below $1 \% .^{38}$

For cars and heavy-duty vehicles (HDVs), India has only very limited experience with around 7,000 e-cars plying the streets as of 2017 and only small numbers of e-buses. Sales of electric cars have not taken up in the last 5 years. A decade ago, India and the PRC had the same number of registered EVs but while the EV market in PRC took off, in India it remained at a marginal level with less than 1,000 new electric cars being registered annually. By 2016, India had fewer than 500 public EV charging stations in major metropolitan areas. ${ }^{39}$ Also, Indian manufacturers of cars and HDVs only recently entered the EV market.

\section{Other Developing Member Countries}

As of 2018, all other DMCs of ADB have less than 1,000 pure electric cars and HDVs (basically buses) operating. However, some countries have large numbers of electric 2- and 3-wheelers, especially Bangladesh with around 600,000 electric 3-wheelers reported (Chapter 11); Viet Nam, where recently e-motorcycles have grown in popularity (Chapter 11); or Nepal where electric 3-wheelers were introduced a decade ago (Chapter 9). However, registration data for electric 2- and 3-wheelers is, in general, not available.

33 McKinsey. 2018a. The Global Electric-Vehicle Market Is Amped and Up and on the Rise.

34 F. Lambert. 2017. Didi (People's Republic of China's Uber) claims to be 'world's largest EV fleet operator' with 260,000 EVs, launches charging network. electrek. 3 November. https://electrek.co/2017/11/03/didi-china-uber-worlds-largest-ev-fleetoperator-charging-network/.

35 Boston Consulting Group. 2018. PR China Mobility Market Overview.

36 Capacities. 2018a. E-Rickshaw Pilot Assessment for Udaipur, Rajasthan.

37 S. Sen. 2018. An electric vehicle and two wheels of change. Livemint. 13 February. https://www.livemint.com/Industry/ xP9CdI9iqcZRtdRxr23FkK/An-electric-vehicle-and-two-wheels-of-change.html.

38 S. Mukherjee and K. Thakkar. 2017. Two wheelers to lead electric vehicle market in India. The Economic Times. 19 September. https://economictimes.indiatimes.com/industry/two-wheelers-to-lead-electric-vehicle-market-in-india/ articleshow/60739035.cms.

39 McKinsey. 2017c. The Future of Mobility in India: Challenges \& Opportunities for the Auto Component Industry. 
Some countries, e.g., Armenia, the Kyrgyz Republic, Mongolia, and Uzbekistan, operate various trolleybus lines, which were already established decades ago.

In conclusion, only the PRC as of today has a significant market share of EVs with some countries like Bangladesh, India, Nepal, and Viet Nam having basically a proliferation of basic e-scooters and 3-wheelers.

\section{CHARGING INFRASTRUCTURE AND ENERGY GRID}

\subsection{Charging Infrastructure}

The main differences between types of charging equipment are (i) the power output range, (ii) the socket and connectors used for charging, and (iii) the communication protocol between the vehicle and the charger. Conventional chargers (level 1 chargers up to 3.7 kilowatt [kW]) and slow chargers (level 2 chargers with 3.7-22 kW) use AC while fast chargers in general DC or tri-phase AC (level 3 chargers more than $22 \mathrm{~kW}) .{ }^{40}$

A basic 2-wheeler uses level 1 chargers, while 3-wheelers also use level 2 units. Passenger cars use all levels of chargers with home-charging generally done at $3.7-7.4 \mathrm{~kW}$ and public charging (e.g., at retail car parks) done at 11-22 kW, with power output at ultra-fast charging stations ranging up to $400 \mathrm{~kW} .^{41}$ However, EVs must also be able to handle the power charge, e.g., most electric cars today can only handle $11 \mathrm{~kW}$. Smaller urban trucks typically use up to $50 \mathrm{~kW}$ chargers, but versions with higher charging options are also available. Due to large battery requirements, buses have DC level 3 charging with "slow" chargers for overnight charging at 20-50 kW and fast chargers (at night or during the day) of up to $400 \mathrm{~kW}$ (used in various PRC cities such as in Beijing). Additionally, buses can also be ultra-fast charged at stations, e.g., the Geneva bus system Trolleybus Optimisation System Alimentation or TOSA uses $600 \mathrm{~kW}$ chargers for ultra-fast charging of 15-30 seconds at stations. Fast charging is not expected to impact the lifetime of batteries if designed appropriately and if the thermal management system is sized appropriately. ${ }^{42}$

The number of chargers per vehicle will depend largely on the country, the density of EVs, and the power of chargers (Figure 18). Leading EV countries have a large number of public charging points-however, there is no universal benchmark for the ratio of EVs to chargers. For example, California has 25-30 EVs per public charger (EV owners have frequent access to home and workplace charging and thus require little public chargers), while in the Netherlands the ratio is 2-7 EVs per public charger (private parking space is more limited in the country). ${ }^{43}$

Cities in the PRC with large numbers of battery electric buses (BEBs) have bus-to charger ratio of 1.5 to 10 , with a low ratio in cities which basically use overnight charging with large battery sets on the bus, and a high ratio in cities with high-powered chargers. Most cities in the PRC have invested in 300-400 kW

40 IEA. 2018b. Global EV Outlook 2018. Paris.

41 IEA. 2018b. Global EV Outlook 2018. Paris; and European Climate Foundation. 2018. Low-Carbon Cars in Europe: A SocioEconomic Assessment; Porsche unveiled in 2017 a 350 kW charging station see Porsche. Porsche opens new branch in Berlin-Adlershof. https://newsroom.porsche.com/de/unternehmen/porsche-zentrum-berlin-adlershof-schnellladeparksolarpylon-13955.html.

42 IEA. 2018b. Global EV Outlook 2018. Paris.

43 ICCT. 2017d. Emerging Best Practices for Electric Vehicle Charging Infrastructure. 


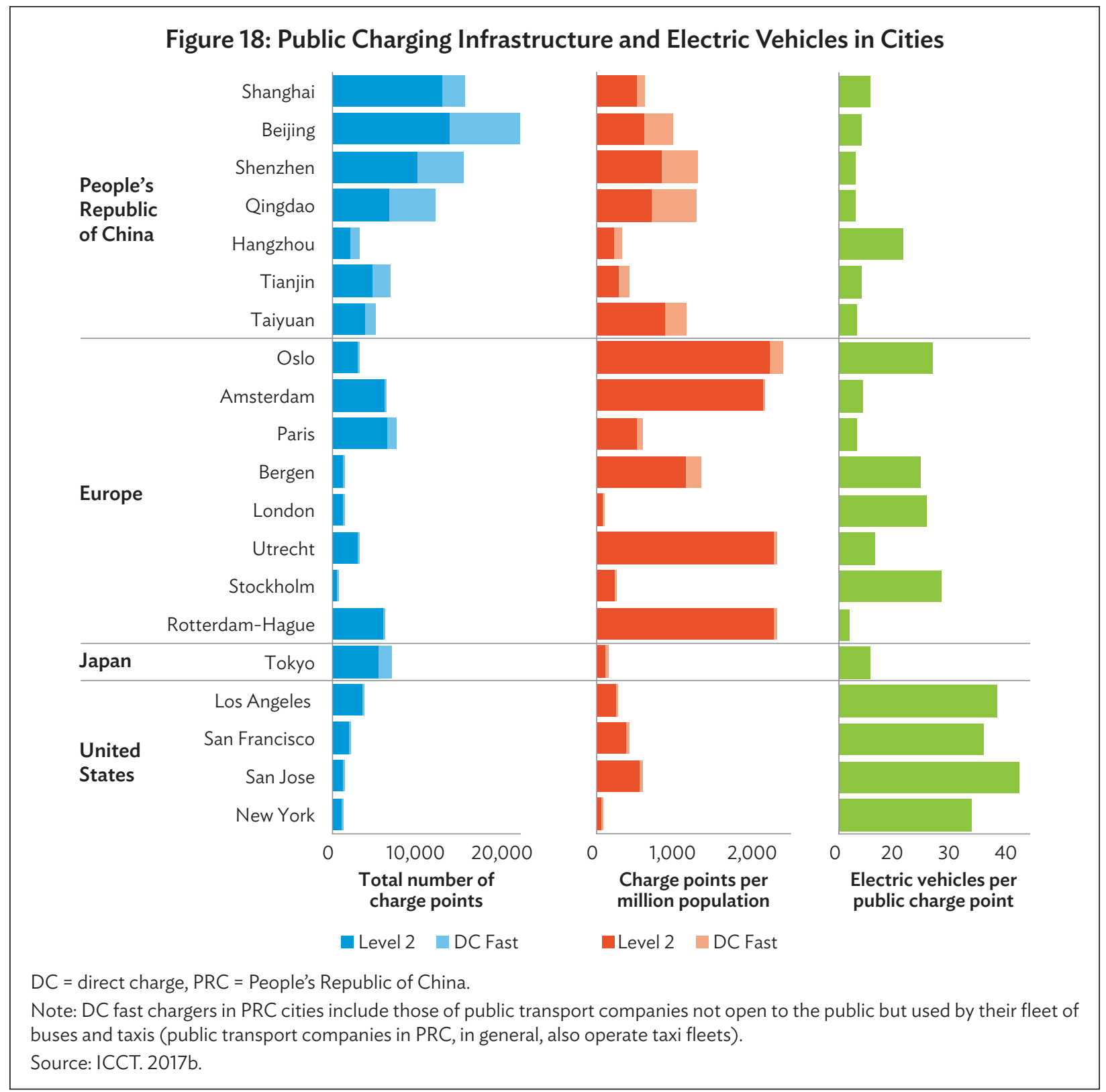

chargers and also charge their buses at night with fast chargers to reduce space requirements for charging buses. $^{44}$

\subsection{Energy Usage}

Research suggests that the installed electrical capacity required to meet the demand from EVs by 2030 will not be a major constraint. ${ }^{45}$ The International Energy Agency (IEA), in its 2 degrees Celsius global warming scenario, estimates that the additional generation needed to meet EV demand represents only $1.5 \%$ of total electricity demand by 2030.

44 Grütter Consulting. 2018. Low Carbon Buses in PRC.

45 OIES. 2018. Disruptive Change in the Transport Sector: Eight Key Takeaways. Oxford. 
Figure 19: Impact of Electric Vehicle Deployment on Global Electricity Demand

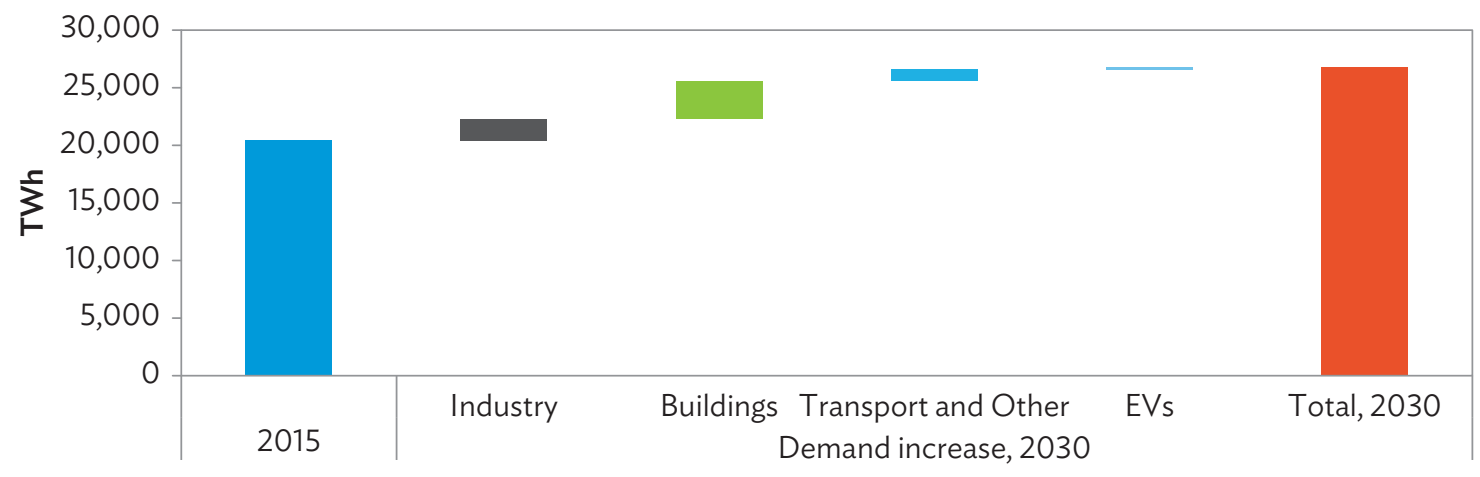

$\mathrm{EV}=$ electric vehicle, $\mathrm{TWh}=$ terawatt hour.

Source: IEA. 2017b.

In Norway, which has the highest EV penetration rate in the word, the estimated electricity demand from 4 million electric cars in 2030 is $2 \%-3 \%$ of the estimated electricity demand in the Nordic region. ${ }^{46} \mathrm{~A}$ UK future energy demand scenario for 2050 shows that EVs could result in an additional 30\% on top of today's peak demand and an additional electricity demand of 35-45 terawatt-hours (TWh) from EVs by 2050. ${ }^{47}$ This scenario assumes that heavy goods vehicles would be gas and not electric powered. ${ }^{48}$ In the PRC, the current electricity demand from EVs is $0.5 \%$ of the total demand. ${ }^{49}$

For most countries, in the next decades, additional electricity demand from transport will be low and will only increase slowly due to low vehicle replacement rates and also due to trucks not yet being electrified. However, electricity demand from EVs can be challenging in the future

- if the majority of vehicles including trucks are electric; and

- in smaller grids, basically oriented to residential and commercial demand with low overall electricity production levels.

The potential impact on electricity demand for a small island-state was modeled after Fiji (Chapter 10). Fiji intends to fully operate EVs by 2030, at the earliest. Being $100 \%$ of its fleet electric in 2050 would result in an electricity demand for mobility of up to five times the current production level. This would create considerable stress on the grid as at the same time Fiji intends to go $100 \%$ renewable by 2050 .

46 IEA. 2018a. Nordic EV Outlook 2018. Paris; the current demand in Norway is 0.8\% of the total demand (IEA. 2018b. Global EV Outlook 2018. Paris).

472015 the electricity demand was 306 TWh, i.e., the additional electricity demand would be around $13 \%$ of 2015 demand.

48 National Grid. 2017. Future Energy Scenarios.

49 IEA. 2018b. Global EV Outlook 2018. Paris. 


\subsection{Smart Charging and Vehicle Grid Integration}

Running $100 \%$ EVs not only stresses the grid in terms of electricity production, but also in terms of power demand. EV charging can have a sizable impact on the loads applied to the grid at certain times and locations. The rise in the number of $\mathrm{EVs}$ can be accommodated fairly easily by power generation facilities as long as the vehicles are charged off-peak. Faster charging during peak demand, however, can have a significant impact. ${ }^{50}$ The extent on which EVs will impact the electricity networks will depend highly on technologies and charging modes used, with the bulk of charging expected to occur in low-voltage distribution grids in residential or commercial areas. ${ }^{51}$ The management of the grid is considered critical rather than absolute capacities. Problems which can occur are increased peak loads and charging hotspots resulting in local network overloading. EV charging can have a sizable impact on the loads applied to the grid at certain times and locations.

Passenger cars are basically charged overnight, which minimizes the need for incremental electricity generation capacity and investment in distribution infrastructure upgrades. Plugging EVs to the grid too early in the evening may, however, result in this additional demand coinciding with the evening peak electricity demand, resulting in a higher risk of overloading the power distribution network, ultimately requiring additional generation capacity and network upgrades.

Solutions being proposed for these problems involve controlled charging and smart charging using demand side management (DSM). For fast charging, managing power demand is also likely to require the deployment of stationary storage at the local level. ${ }^{52}$

\section{Demand Side Management}

DSM is an instrument that can reduce the need for grid upgrades and additional generation capacity. It consists largely of optimizing the charging time to match power supply and demand, basically shifting charging to night or midday, depending on the grid. ${ }^{53}$ Instruments used include dynamic tariffs incentivizing customers to charge EVs when optimal, assisted with smart charging applications which facilitate the work of customers by allowing them to take advantage of the dynamic tariff (Figure 20).

The effectiveness of DSM can be enhanced by bi-directional "vehicle-to-grid" (V2G) capabilities where power can flow from the grid to the vehicle and vice versa. ${ }^{54}$ This could also be an attractive source of revenue for EV owners.

High-powered chargers potentially result in overloading of local grids and can lead to very high demand charges, resulting in high electricity prices. One way to resolve this problem is stationary battery storage with on-site batteries charging at lower power from the grid when costs are lower, store the power, and release it when demand is higher (a practice called "peak shaving"). This is done, for example, on the Geneva TOSA line where buses are charged ultra-fast at stations from 15 to 30 seconds with $600 \mathrm{~kW}$ based on on-site batteries, which are continuously charged at lower power levels.

50 Peak demand from a single EV using a top-of-the-range fast charger can be 80 times higher than the expected peak demand of a single typical household. McKinsey. 2018b. Three Surprising Resource Implications from the Rise of Electric Vehicles.

51 IEA. 2017b. Global EV Outlook 2017. Paris.

52 IEA. 2017b. Global EV Outlook 2017. Paris.

53 High non-demanded power generation from wind generators during the night and solar PV at midday.

54 IEA. 2018b. Global EV Outlook 2018. Paris. 


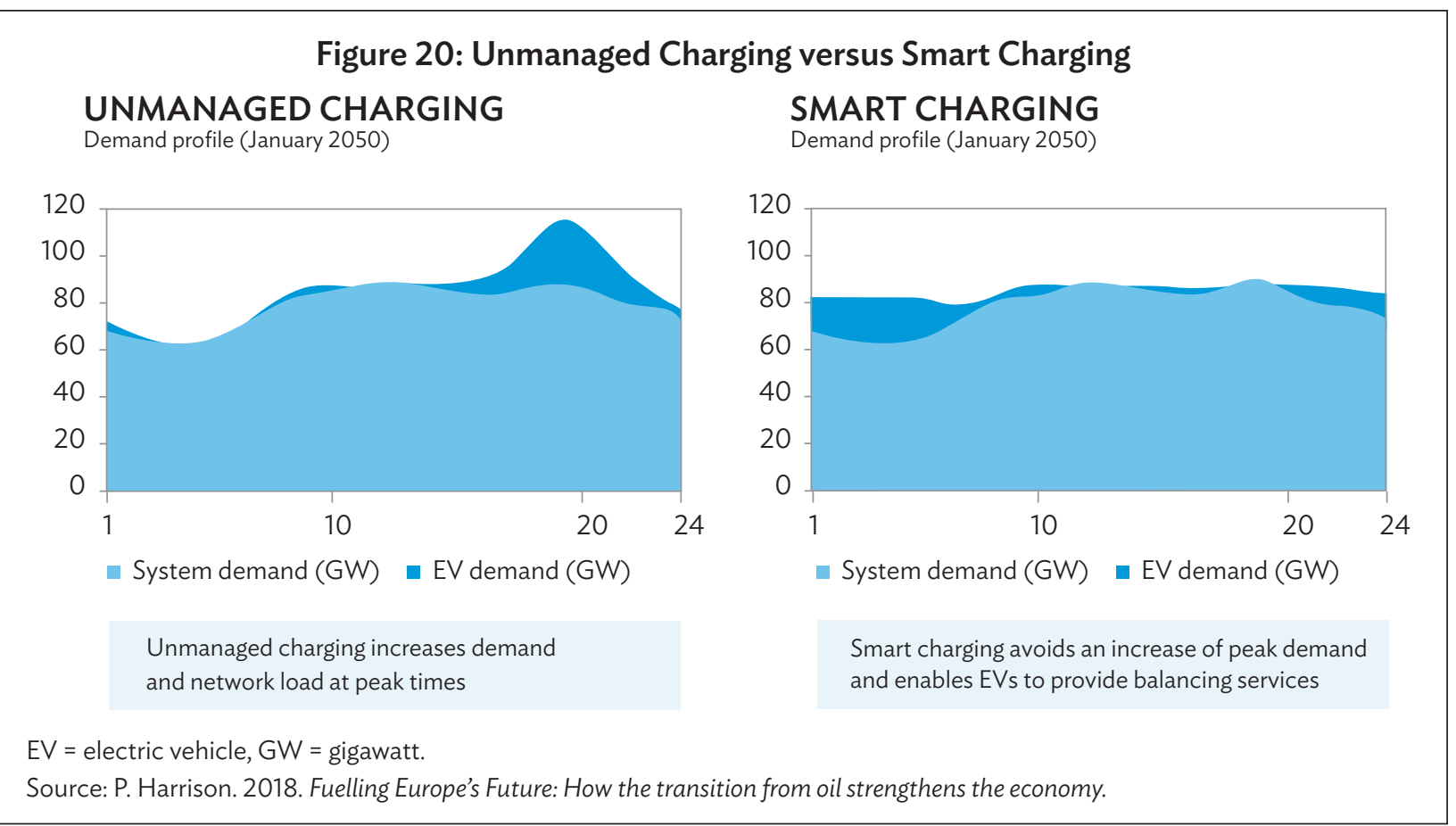

Increasing renewable energy penetration rates requires sufficient energy storage systems due to unpredictability of renewable sources (e.g., wind, solar) especially for small island states. EV fleets could play a role as distributed energy storage systems, thereby helping to increase the participation of renewables. Second-life batteries from EVs can also play an important role in storing the fluctuating supply of energy from renewables. ${ }^{55}$

\section{ELECTRIC VEHICLES AND THE ENVIRONMENT}

\subsection{Introduction}

Emissions of vehicles have different sources as can be seen from the following graph.

\section{Fuel- and/or Energy-Related Emissions}

Combustion emissions occur when operating the vehicle and are, for greenhouse gases (GHGs), directly related to the energy usage of the vehicle. They are separated in direct or tank-to-wheel (TTW) and indirect or well-to-tank (WTT) emissions (combined well-to-wheel [WTW] emissions). For EVs, WTT GHG emissions are those caused by electricity production including transmission and distribution losses.

55 F. Lambert. 2018. Renault is trying to create a 'smart electric island' with electric vehicles, V2G, and energy storage. electrek. 21 February. https://electrek.co/2018/02/21/renault-smart-electric-island-electric-vehicles-v2g-energy-storage/. 


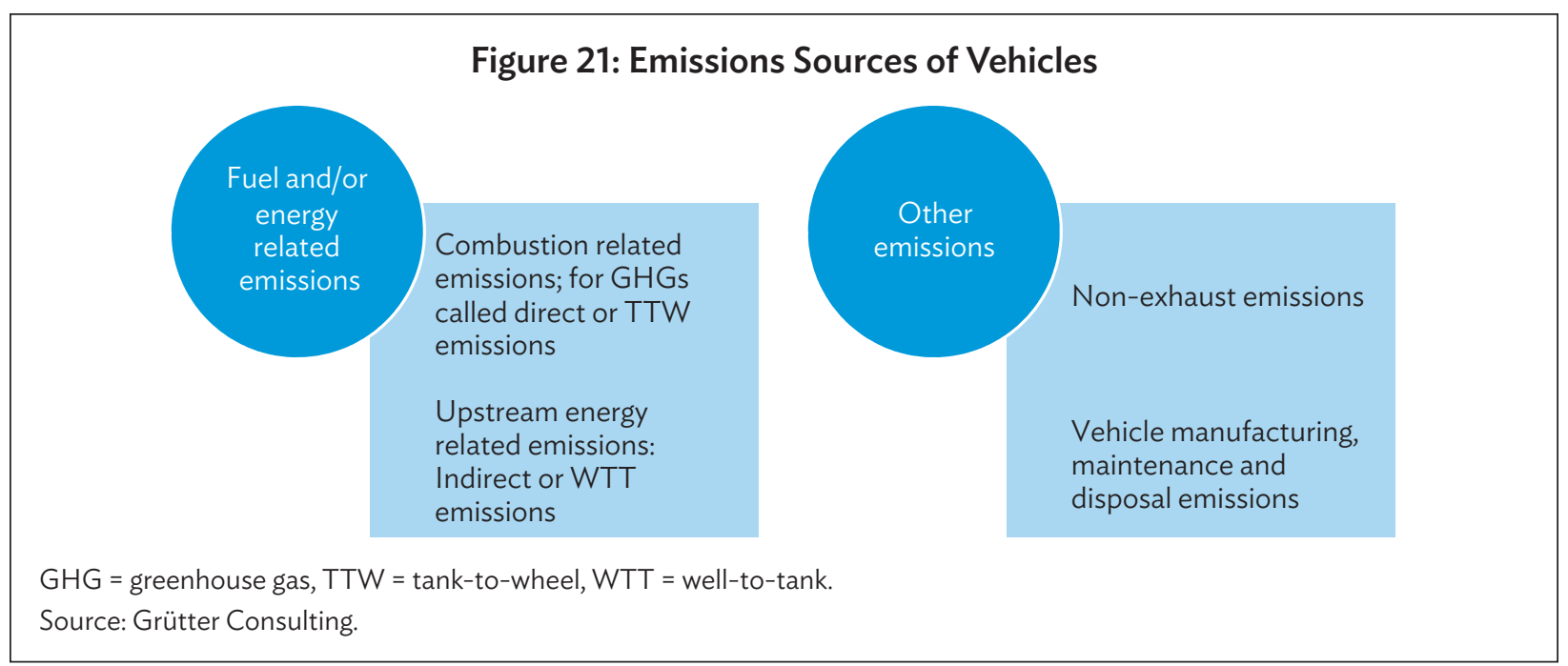

\section{Other Emissions}

Non-exhaust emissions are related to vehicle operations, but not to the fuel quantity used. They include emissions from brake, tire, and particle re-suspension. Vehicle manufacturing, maintenance, and disposal emissions look at environmental impacts caused during the manufacturing and disposal of the vehicle and its components, e.g., batteries, in the case of EVs.

\section{Comparison Base}

EVs are basically promoted to reduce emissions. To determine the actual reduction impact, information is not only required about the emissions caused by the EV but also the emissions that would have been caused by a conventional vehicle in absence of purchasing an EV. The methodological approach is, therefore, to compare the emissions of a new conventional vehicle with the emissions of a new EV of the same vehicle category, characteristics, and functionality. Emissions of vehicles will depend on the emission standard enforced in the country (basically for local pollutants plus for diesel vehicles concerning black carbon [BC] emissions) and the baseline fuel used (diesel, gasoline, gaseous fuels). Comparisons are therefore made, whenever relevant, with the main baseline vehicle types.

\subsection{Greenhouse Gas Emissions}

\subsubsection{Introduction}

GHGs included under the United Nations Framework Convention on Climate Change (UNFCCC) are carbon dioxide $\left(\mathrm{CO}_{2}\right)$, methane, nitrous oxides, perfluorocarbons, hydrofluorocarbons, sulfur hexafluoride, and trifluoride nitrogen. Only $\mathrm{CO}_{2}$, methane, and nitrous oxide are relevant to the transport sector. However, according to UNFCCC methodologies for determining emissions from the transport sector, nitrous oxide emissions are very marginal. Therefore, only $\mathrm{CO}_{2}$ emissions are included and, in addition for gaseous fuel-powered engines, emissions of methane. ${ }^{56}$

56 IPCC. 2006. IPCC Guidelines for National Greenhouse Gas Inventories. Chapter 3. 
Additionally, BC emissions are included due to their climate relevance. A scientific assessment of $\mathrm{BC}$ emissions and impacts found that these are second to $\mathrm{CO}_{2}$ in terms of climate forcing. $\mathrm{BC}$ is on average 2,700 times more effective on a mass-equivalent basis than $\mathrm{CO}_{2}$ in causing climate impacts within 20 years, and 900 times more effective within 100 years. ${ }^{57} \mathrm{BC}$ is part of particulate matter (PM) originating primarily from diesel engines.

\subsubsection{Direct Greenhouse Gas Emissions (Tank-to-Wheel)}

Direct GHG emissions are calculated for fossil fuels based on the quantity of fuel used, the net calorific value of the fuel, and the $\mathrm{CO}_{2}$ emission factor of the fuel. ${ }^{58}$ Direct $\mathrm{GHG}$ emissions also include for gaseous vehicles methane slip occurring within the vehicle as this is a relevant emission source. Methane slip can be determined based on average reported values of the International Council on Clean Transportation (ICCT), which summarizes different sources. Leakage of unburnt methane is important due to the high global warming potential of methane. Methane slip is caused within the vehicle in the crankcase and the exhaust pipe and "upstream" due to leaks in the gas pumps and wells. ${ }^{59}$ The GHG impact of BC is determined based on the mass of $\mathrm{PM}_{2.5}$ emissions, the fraction of $\mathrm{BC}$ in $\mathrm{PM}_{2.5}$, and the global warming potential of BC.

Direct GHG emissions of EVs are zero. Figure 22 shows average GHG emissions per kilometer of motorcycles, 3-wheelers, passenger cars, urban buses, and long-haul trucks based on the most common fuel type and vehicle size per category.

\section{Figure 22: Average Tank-to-Wheel Greenhouse Gas Emissions of Standard Vehicle Categories $\left(\mathrm{gCO}_{2} \mathrm{e} / \mathrm{km}\right)$}

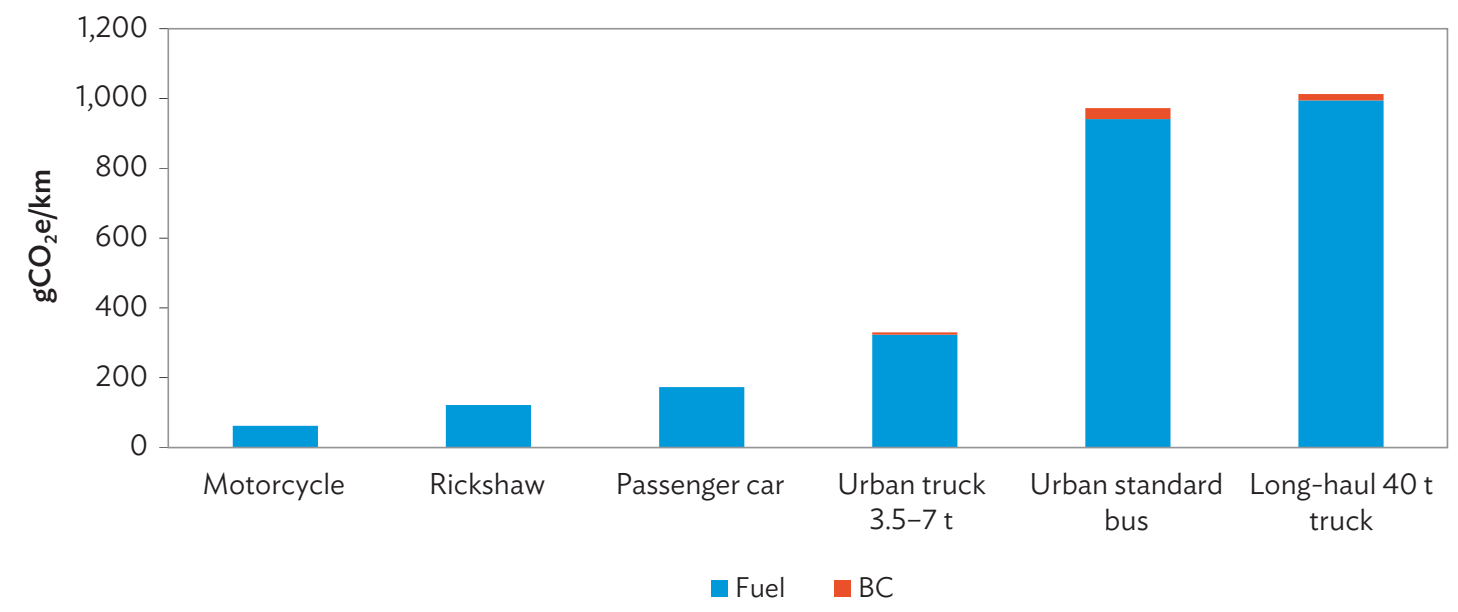

$\mathrm{BC}$ = black carbon, $\mathrm{CNG}=$ compressed natural gas, $\mathrm{gCO}_{2} \mathrm{e} / \mathrm{km}=$ gram of carbon dioxide equivalent per kilometer, $\mathrm{t}=$ ton. Note: Based on gasoline motorcycle (urban scooter); CNG rickshaw; urban 12-meter diesel bus Euro IV; urban delivery truck 3.5-7 t diesel Euro IV; long-haul 40 t diesel truck Euro IV; fuel consumption values based on average measurements in various Asian cities; $B C$ values of diesel vehicles based on COPERT; see Appendix for details.

Source: Grütter Consulting.

57 Bond et al. 2013. Bounding the Role of Black Carbon in the Climate System: A Scientific Assessment. Journal of Geophysical Research. doi:10.1002/jgrd.50171. or World Bank. 2014a. Reducing Black Carbon Emissions from Diesel Vehicles: Impacts, Control Strategies, and Cost-Benefit Analysis. Washington, DC.

58 See IPCC, 2006 for NCV and $\mathrm{EFCO}_{2}$ values of different fuels.

59 ICCT. 2015. Assessment of Heavy Duty Natural Gas Vehicles Emissions: Implications and Policy Recommendations. 


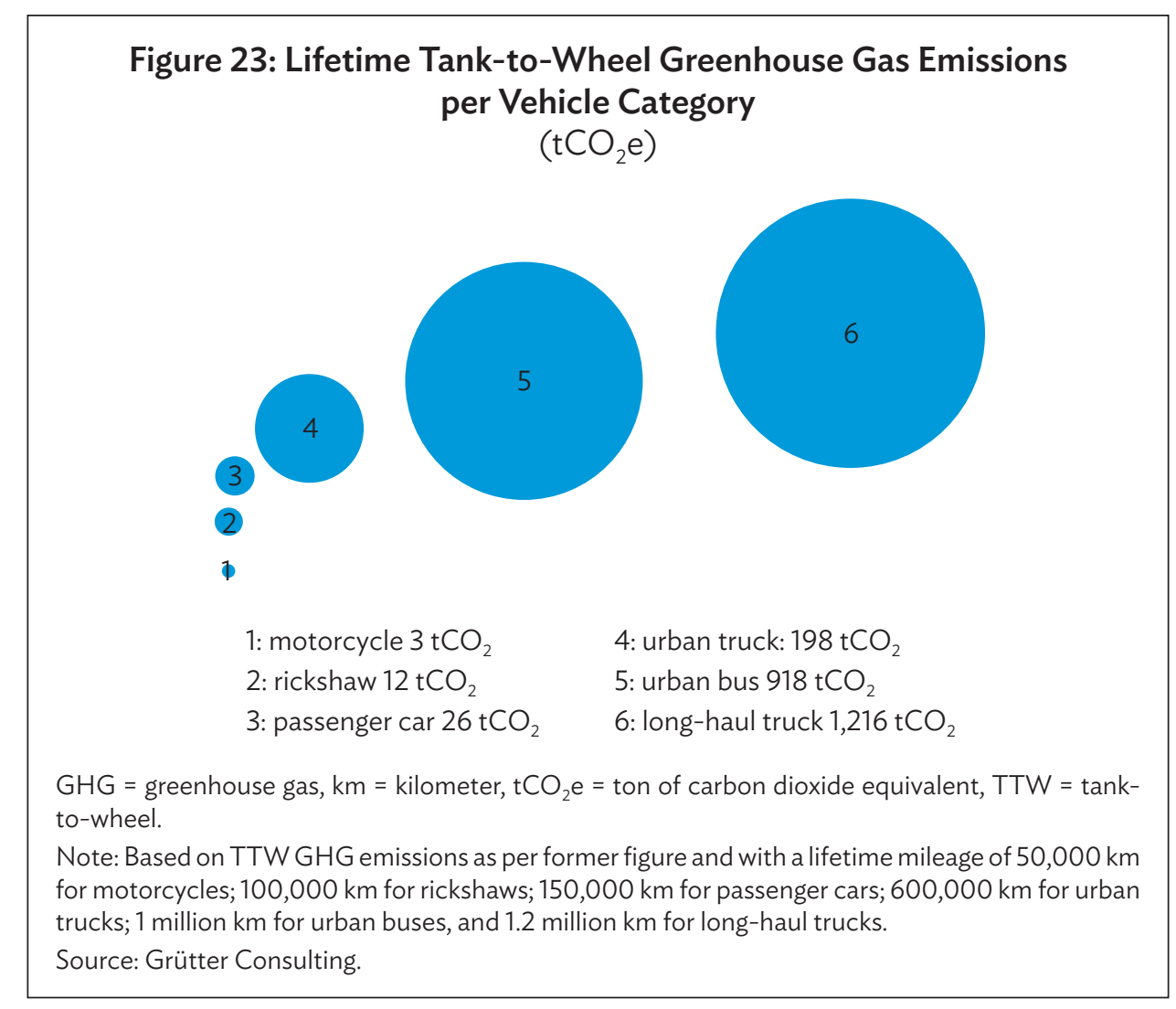

Notable is that Black Carbon emissions using Euro standard 4 are not significant (less than 5\% of TTW GHG emissions). ${ }^{60}$ The potential GHG impact of substituting a fossil fuel vehicle with an EV is, however, not only dependent on the GHG emissions per kilometer, but also on the average annual distance driven and the commercial life span of the vehicle. The following figure gives an indication of average lifetime TTW GHG emissions per vehicle and, therefore, the potential lifetime impact (TTW) of substituting a fossil with an electric unit.

The GHG emissions over the life span of a long-haul truck are 400 times more than for a motorcycle. Considering the lifetime emissions replacing one conventional urban bus with an EV unit has the same impact as replacing 35 passenger cars or 300 motorcycles. The 380,000 e-buses in the PRC are, therefore, as significant in GHG terms as more than 13 million electric cars.

\subsubsection{Direct and Indirect Greenhouse Gas Emissions (Well-to-Wheel)}

Indirect or well-to-tank (WTT) emissions are upstream fuel consumption-related emissions. These include GHG emissions for the extraction, refining, and transportation of fossil fuels, determined by using a default mark-up factor per fossil fuel type published by the UNFCCC (19\% for gasoline, 23\% for diesel, $18 \%$ for compressed natural gas [CNG], and $28 \%$ for liquefied natural gas). ${ }^{61}$ For gaseous fuels,

60 However, for (currently operating) diesel vehicles with older Euro standards BC emissions can be significant.

61 UNFCCC. 2014. CDM Methodological Tool: Upstream Leakage Emissions Associated with Fossil Fuel Usage, Version 02.0. Bonn. Table 3. 


\section{Box 2: Why the Combined Margin Approach Is Not Appropriate for Electric Vehicles}

The United Nations Framework Convention on Climate Change (UNFCCC) approach using the Combined Margin (CM) is not applied as it was designed primarily for renewable energy projects trying to capture what electricity would be displaced from more GHG intensive means (https://cdm.unfccc.int/methodologies/PAmethodologies/ tools/am-tool-07-v6.pdf). The CM does not reflect actual GHG emissions of the electric grid and in some cases can be far off actual emissions due to: (i) non-inclusion of low-cost/must-run (LCMR) resources defined as power plants with low marginal generation costs or dispatched independently of the daily or seasonal load of the grid including primarily hydro, geothermal, wind, low-cost biomass, nuclear and solar generation and (ii) the non-inclusion of Clean Development Mechanism (CDM) projects in the CM. Especially the non-inclusion of LCMR resources can result in widely misleading results. A country producing, e.g., $40 \%$ of electricity with renewables have a high $\mathrm{CM}$ as all renewable plants are classified as LCMR. As example, Costa Rica which produces $98 \%$ of electricity with renewables has a CM of $0.25 \mathrm{kgCO}_{2} / \mathrm{kWh}$ while the actual monitored carbon factor of the entire electricity sector is less than $0.01 \mathrm{kgCO}_{2} /$ kWh (CM see, e.g., https://cdm.unfccc.int/Projects/DB/AENOR1356681996.92/view; actual value see data from IEA).

Source: Grütter Consulting.

upstream methane slip is also included. EVs cause upstream emissions due to usage of electricity which has production-related emissions as well as transmission and distribution losses. The carbon emission factor of the grid is calculated based on the net energy production (total domestic production minus energy losses) and the total GHG emissions for electricity production, i.e., the actual carbon factor of the grid. ${ }^{62}$

The impact of EVs and their electricity consumption is related to the actual grid emissions, reflecting the emissions caused by EVs in the same manner as any other electricity consuming device in the same country. The grid emission factor is calculated based on the total electricity produced minus losses and the total GHG emissions of the electricity production sector. In the case of countries with a very high component of heat production in combined heat-power plants, this is taken into consideration (e.g., Mongolia). Table 4 shows the grid factor of ADB developing member countries (DMCs) based on the most recent available data.

Figure 24 compares GHG WTW reductions of selected popular vehicle categories with two levels of GHG grid emissions (lower and upper 20 percentile).

In the lower percentile, EVs reduce WTW GHG emissions by $70 \%-80 \%$ depending on the vehicle category, and with the upper 20 percentile of the grid factor EVs still reduce GHG WTW emissions by $20 \%$ (buses) to $60 \%$ (motorcycles and rickshaws). Even Turkmenistan with the highest grid factor of DMCs (1.05 $\mathrm{kgCO}_{2} \mathrm{e} / \mathrm{kWh}$ ) would, on average, not have higher GHG WTW emissions by using EVs. Thus, while the grid factor will greatly influence the GHG impact of EVs, countries with a grid dominated by fossil fuel sources can still profit from GHG reductions. Figure 25 shows the benchmark grid factor below which EVs reduce GHG emissions. This benchmark is also valid, including upstream emissions as vehicle manufacturing plus battery GHG emissions of conventional vehicles are the same as for EVs (pure manufacturing emissions are higher for internal combustion engines than for EVs due basically to a longer life span of EVs while EVs have additionally battery emissions; see the following chapter for more details).

62 Exports and imports are not considered, i.e., this is the grid factor of nationally produced electricity. 
Table 4: Grid Carbon Factors of ADB Developing Member Countries

\begin{tabular}{|c|c|c|c|}
\hline Country & $\begin{array}{l}\text { Grid Factor } \\
\mathrm{kgCO}_{2} \mathrm{e} / \mathrm{kWh}\end{array}$ & Year & Source \\
\hline Afghanistan & 0.71 & 2005 & $\begin{array}{l}\text { Electricity: M.W. Addison (2007), Energy Sector Strategy Islamic Republic } \\
\text { of Afghanistan, Table } 3 \text { (consumption minus imports); GHG emissions: } \\
\text { NEPA, 1st NC (2013), Table } 12\end{array}$ \\
\hline Armenia & 0.16 & 2016 & $\begin{array}{l}\text { GEF (2017), Grid EF for Armenia 2014-2016, standardized baseline } \\
\text { UNFCCC approved; Based on total } \mathrm{CO}_{2} \text { and delivered electricity minus } \\
\text { imports }\end{array}$ \\
\hline Azerbaijan & 0.57 & 2015 & IEA (2017) for GHG; IEA a for electricity production minus losses \\
\hline Bangladesh & 0.64 & 2015 & IEA (2017) for GHG; IEA for electricity production minus losses \\
\hline Bhutan & 0.00 & 2017 & 99.94\% renewable electricity production; see also NEC, 2nd NC (2011) \\
\hline Cambodia & 0.70 & 2015 & IEA (2017) for GHG; IEA for electricity production minus losses \\
\hline Cook Islands & 0.17 & 2017 & $\begin{array}{l}\text { End- } 201780 \% \text { renewable electricity and target for } 2020 \text { is 100\% renewable } \\
\text { (see NDC)b }\end{array}$ \\
\hline Fiji & 0.37 & 2015 & $\begin{array}{l}\text { FEA annual report 2015, p. } 23 \text { (electricity generation); fuel used p. 24; } \\
\text { average NCV and } \mathrm{EFCO}_{2} \text { per fuel type of IPCC (2006) }\end{array}$ \\
\hline Georgia & 0.13 & 2015 & IEA (2017) for GHG; IEA for electricity production minus losses \\
\hline India & 0.82 & 2015 & $\begin{array}{l}\text { CEA (2017), } \mathrm{CO}_{2} \text { Baseline Database Vs. 12; total net electricity generation } \\
\text { and total } \mathrm{CO}_{2} \text { emissions }\end{array}$ \\
\hline Indonesia & 0.81 & 2015 & IEA (2017) for GHG; IEA for electricity production minus losses \\
\hline Kazakhstan & 0.82 & 2015 & IEA (2017) for GHG; IEA for electricity production minus losses \\
\hline Kiribati & 0.71 & 2014 & $\begin{array}{l}\text { IRENA (2017), Kiribati Integrated Energy Roadmap: 2017-2025, p. 15: diesel } \\
\text { consumption; NCV and EFCO } \text { of IPCC (2006) }^{\text {IPC }} \text { (20) }\end{array}$ \\
\hline Kyrgyz Republic & 0.28 & 2015 & IEA (2017) for GHG; IEA for electricity production minus losses \\
\hline Lao PDR & 0.00 & 2017 & MONRE, 2nd NC (2013); 100\% hydropower \\
\hline Malaysia & 0.73 & 2015 & IEA (2017) for GHG; IEA for electricity production minus losses \\
\hline Maldives & 0.46 & 2012 & $\begin{array}{l}\text { Maldives Energy Authority (2014), Maldives Energy Supply \& Demand } \\
\text { 2010-2012, based on primary energy consumption }\end{array}$ \\
\hline Marshall Islands & 0.68 & 2012 & $\begin{array}{l}\text { NREL (2015), Energy Project Development Options and Technical } \\
\text { Assessment, Table 2; NCV and EFCO }{ }_{2} \text { for FO based on IPCC (2006) }\end{array}$ \\
\hline $\begin{array}{l}\text { Federated States } \\
\text { of Micronesia }\end{array}$ & 0.69 & 2010 & $\begin{array}{l}\text { IRENA (2013), Renewable energy opportunities and challenges in the } \\
\text { Pacific Islands region, Table 4; NCV plus } \mathrm{EFCO}_{2} \text { of FO from IPCC (2006) }\end{array}$ \\
\hline Mongolia & 0.87 & 2015 & $\begin{array}{l}\text { Standardized Baseline proposal at UNFCCC (2017) based on total } \\
\text { electricity and total GHG excluding imports }\end{array}$ \\
\hline Myanmar & 0.37 & 2015 & IEA (2017) for GHG; IEA for electricity production minus losses \\
\hline Nauru & 0.92 & 2010 & $\begin{array}{l}\text { IRENA (2013), Nauru Energy Sector Summary Report, Table 3; energy } \\
\text { losses (not including non-technical) p. 7; NCV and EFCO } \text { of IPCC (2006) }_{\text {for diesel }}\end{array}$ \\
\hline Nepal & 0.00 & 2015 & IEA (2017) for GHG; IEA for electricity production minus losses \\
\hline Pakistan & 0.50 & 2015 & IEA (2017) for GHG; IEA for electricity production minus losses \\
\hline Palau & 0.71 & 2011 & 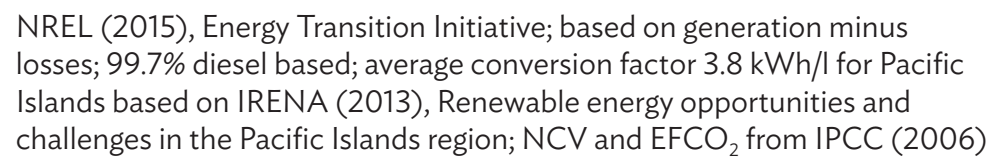 \\
\hline
\end{tabular}


Table 4 continued

\begin{tabular}{|c|c|c|c|}
\hline Country & $\begin{array}{l}\text { Grid Factor } \\
\mathrm{kgCO}_{2} \mathrm{e} / \mathrm{kWh}\end{array}$ & Year & Source \\
\hline Papua New Guinea & 0.51 & 2007 & $\begin{array}{l}\text { OCCD, 2nd NC (2014), electricity generation p. } 16 \text { with } 72 \% \text { thermal; } \\
\text { calculation of GHG based on diesel production with average conversion } \\
\text { factor } 3.8 \mathrm{kWh} / \mathrm{l} \text { for Pacific Islands based on Irena (2013); NCV and } \mathrm{EFCO}_{2} \\
\text { from IPCC (2006) }\end{array}$ \\
\hline PRC & 0.79 & 2015 & IEA (2017) for GHG; IEA for electricity production minus losses \\
\hline Philippines & 0.68 & 2015 & IEA (2017) for GHG; IEA for electricity production minus losses \\
\hline Samoa & 0.40 & 2007 & MNRE, 2nd NC GHG Inventory (2008), Table 2.3. Figure 3.4 \\
\hline Solomon Islands & 0.94 & 2010 & MECDM, 2nd NC (2017), Tables 9 and 33 \\
\hline Sri Lanka & 0.55 & 2015 & IEA (2017) for GHG; IEA for electricity production minus losses \\
\hline Tajikistan & 0.02 & 2015 & IEA (2017) for GHG; IEA for electricity production minus losses \\
\hline Thailand & 0.55 & 2015 & IEA (2017) for GHG; IEA for electricity production minus losses \\
\hline Timor-Leste & 0.83 & 2014 & $\begin{array}{l}\text { DIEACC, 1st NC (2014), Table 1-7; diesel oil used; NCV and } \mathrm{EFCO}_{2} \text { of IPCC } \\
\text { (2006) }\end{array}$ \\
\hline Tonga & 0.67 & 2008 & $\begin{array}{l}\text { Government of Tonga (2010), Tonga Energy Roadmap 2010-2020, Table } \\
\text { 3-1; diesel generation: NCV and } \mathrm{EFCO}_{2} \text { of IPCC (2006) }\end{array}$ \\
\hline Turkmenistan & 1.05 & 2015 & IEA (2017) for GHG; IEA for electricity production minus losses \\
\hline Tuvalu & 0.69 & 2015 & $\begin{array}{l}\text { Government of Tuvalu, 2nd NC (2015), Table 3; diesel oil used NCV and } \\
\text { EFCO }_{2} \text { of IPCC (2006) }\end{array}$ \\
\hline Uzbekistan & 0.76 & 2015 & IEA (2017) for GHG; IEA for electricity production minus losses \\
\hline Vanuatu & 0.55 & 2012 & Republic of Vanuatu, 2nd NC (2014), Table 4.2 \\
\hline Viet Nam & 0.53 & 2015 & IEA (2017) for GHG; IEA for electricity production minus losses \\
\hline \multicolumn{4}{|l|}{ Data Summary } \\
\hline Lowest value & 0.00 & & Bhutan, Lao PDR, and Nepal \\
\hline Lower 20 percentile & 0.35 & & \\
\hline Median & 0.66 & & \\
\hline Upper 20 percentile & 0.79 & & \\
\hline Highest value & 1.05 & & Turkmenistan \\
\hline
\end{tabular}

$\mathrm{CEA}=$ Central Electricity Authority, $\mathrm{CO}_{2}=$ carbon dioxide, DIEACC = Directorate for International Environmental Affairs and Climate Change, $\mathrm{EFCO}_{2}=$ Emission Factor of Carbon Dioxide, $\mathrm{kgCO}_{2} \mathrm{e} / \mathrm{kWh}=$ kilogram of carbon dioxide equivalent per kilowatt-hour, $\mathrm{kWh} / \mathrm{l}=$ kilowatt-hour per liter, $\mathrm{FO}=$ Fuel Oil, GEF = Global Environmental Facility, GHG = greenhouse gas, IEA = International Energy Agency, IPCC = Inter-Governmental Panel on Climate Change, IRENA = International Renewable Energy Agency, Lao PDR = Lao People's Democratic Republic, MECDM = Ministry of Environment, Climate Change and Disaster Management, MNRE = Ministry of Natural Resources and Environment, MONRE = Ministry of Natural Resources and Environment, NC = National Communications, $\mathrm{NCV}=$ net calorific value, NEC = National Environment Commission, NEPA = National Environmental Protection Agency, NREL $=$ National Renewable Energy Laboratory, OCCD = Office of Climate Change and Development, PRC = People's Republic of China, UNFCCC = United Nations Framework Convention on Climate Change.

a International Energy Agency. Statistics. www.iea.org/statistics/ (accessed 18 October 2018).

b K. Ross. 2016. Cook Islands On Target To Be 100 Percent Renewable. Renewable Energy World. 18 January. http://www. renewableenergyworld.com/articles/2016/01/cook-islands-on-target-to-be-100-percent-renewable.html.

c Combined heat and electricity production is very important in Mongolia and the standardized baseline approach assigns GHG emissions towards heating and electricity which makes it a more appropriate approach than IEA statistics.

Source: compiled and calculated by Grütter Consulting based on the data sources indicated per country. 
Figure 24: Average Well-to-Wheel Greenhouse Gas Emissions of Standard Vehicle Categories $\left(\mathrm{gCO}_{2} \mathrm{e} / \mathrm{km}\right)$

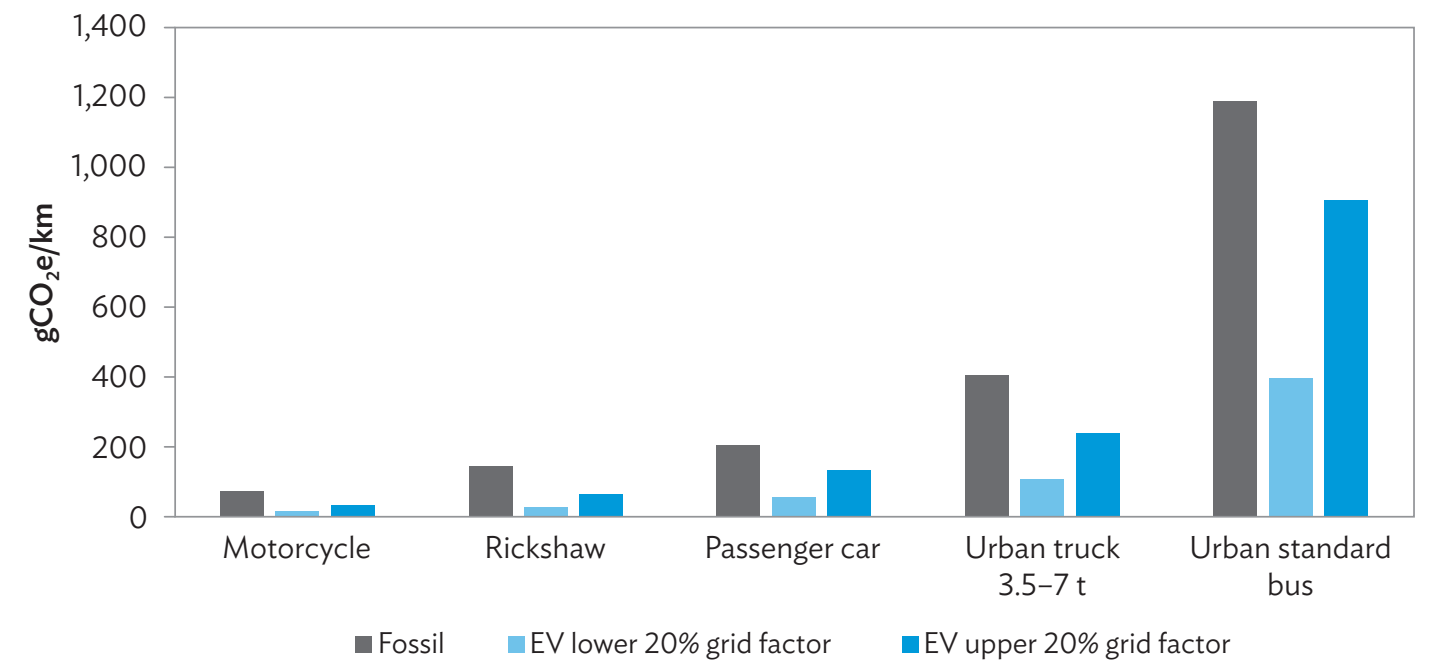

$\mathrm{CNG}=$ compressed natural gas, $\mathrm{EV}=$ electric vehicle, $\mathrm{gCO}_{2} \mathrm{e} / \mathrm{km}=$ gram of carbon dioxide equivalent per kilometer, $\mathrm{t}=$ ton. Note: Fossil fuel baseline gasoline motorcycle (urban scooter); CNG rickshaw; urban truck 3.5-7 t diesel Euro IV urban 12-meter diesel bus Euro IV; energy consumption values based on average measurements in various Asian cities; $B C$ values of diesel vehicles based on COPERT.

Source: Grütter Consulting.

Figure 25: Benchmark Grid Factor for Electric Vehicles

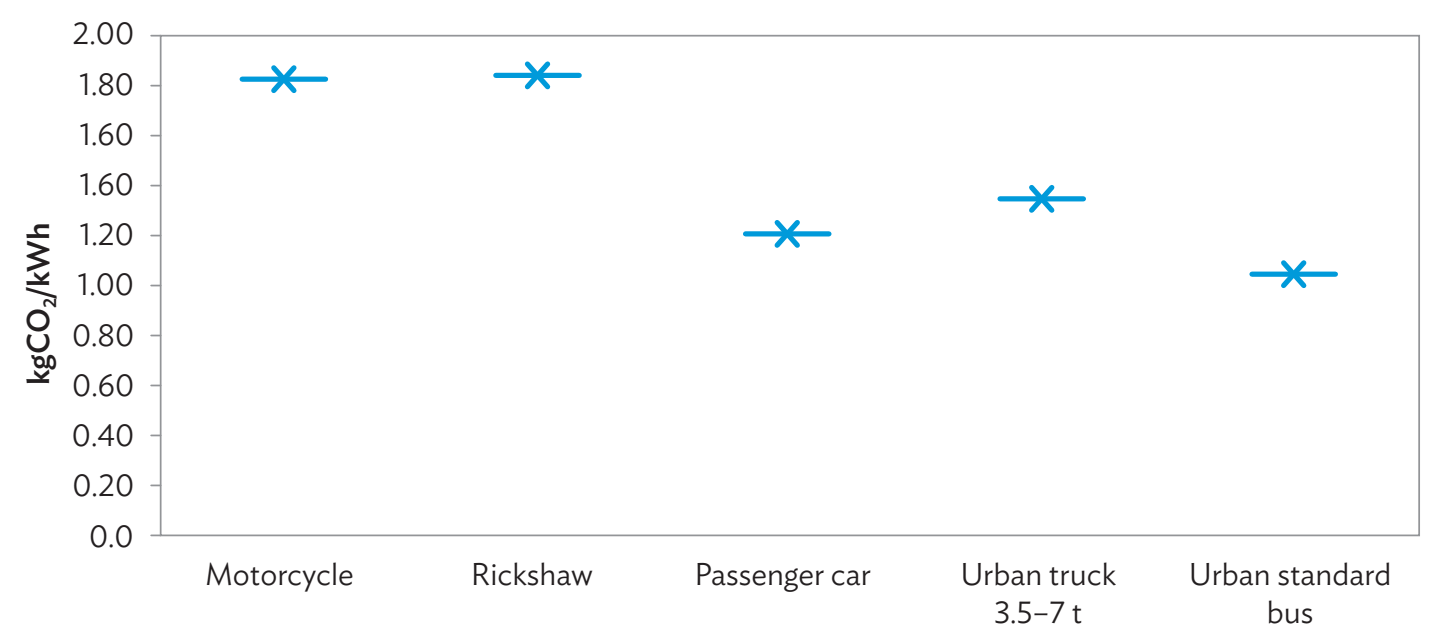

$\mathrm{EV}=$ electric vehicle, $\mathrm{GHG}=$ greenhouse gas, $\mathrm{kgCO}_{2} \mathrm{e} / \mathrm{kWh}=$ kilogram of carbon dioxide per kilowatt-hour, $\mathrm{t}=$ ton. Note: In countries with a grid factor above this benchmark, EV usage increases GHG emissions.

Source: Grütter Consulting. 
Table 5 indicates DMCs with a low carbon grid $\left(<0.35 \mathrm{kgCO}_{2} \mathrm{e} / \mathrm{kWh}\right)$, countries with an average grid (from $0.35 \mathrm{kgCO}_{2} \mathrm{e} / \mathrm{kWh}$ to $0.8 \mathrm{kgCO}_{2} \mathrm{e} / \mathrm{kWh}$ ) and countries with a high grid factor ( $>0.80 \mathrm{kgCO}_{2} \mathrm{e} / \mathrm{kWh}$ ).

An average vehicle lifetime is $10-15$ years (less for 2 -wheelers). While many countries plan to green their grids, the speed of reducing carbon intensity of the grid is critical for countries with a high grid factor - with a slow transformation of the grid, it might be a more effective and financially attractive strategy to initially green the grid and only at a later stage invest additional resources in EVs (Figure 26)

Table 5: Greenhouse Gas Reduction Potential with Deployment of Electric Vehicles

\begin{tabular}{lll}
\hline $\begin{array}{l}\text { GHG Reduction } \\
\text { Potential }\end{array}$ & Carbon Grid Factor & \multicolumn{1}{c}{ Countries } \\
\hline High & $<0.35 \mathrm{kgCO}_{2} \mathrm{e} / \mathrm{kWh}$ & $\begin{array}{l}\text { Armenia, Bhutan, Cook Islands, Georgia, Kyrgyz Republic, Lao PDR, Nepal, } \\
\text { Tajikistan }\end{array}$ \\
& $>0.35 \mathrm{kgCO}_{2} \mathrm{e} / \mathrm{kWh}$ & $\begin{array}{l}\text { Afghanistan, Azerbaijan, Bangladesh, Cambodia, Federated States of } \\
\text { Medium }\end{array}$ \\
& $<0.8 \mathrm{kgCO}_{2} \mathrm{e} / \mathrm{kWh}$ & $\begin{array}{l}\text { Micronesia, Fiji, Kiribati, Malaysia, Maldives, Marshall Islands, Myanmar, } \\
\text { Pakistan, Palau, Papua New Guinea, PRC, Philippines, Samoa, Sri Lanka, } \\
\text { Thailand, Tonga, Tuvalu, Uzbekistan, Vanuatu, Viet Nam }\end{array}$ \\
& $\begin{array}{l}\text { India, Indonesia, Kazakhstan, Mongolia, Nauru, Solomon Islands, Timor-Leste, } \\
\text { Low }\end{array}$ & \begin{tabular}{l} 
Turkmenistan \\
\hline
\end{tabular}
\end{tabular}

GHG = greenhouse gas, Lao PDR = Lao People's Democratic Republic, PRC = People's Republic of China.

Source: Grütter Consulting, based on Table 4.

\section{Figure 26: ADB Developing Member Countries with a Fast Greening of the Electricity Grid}

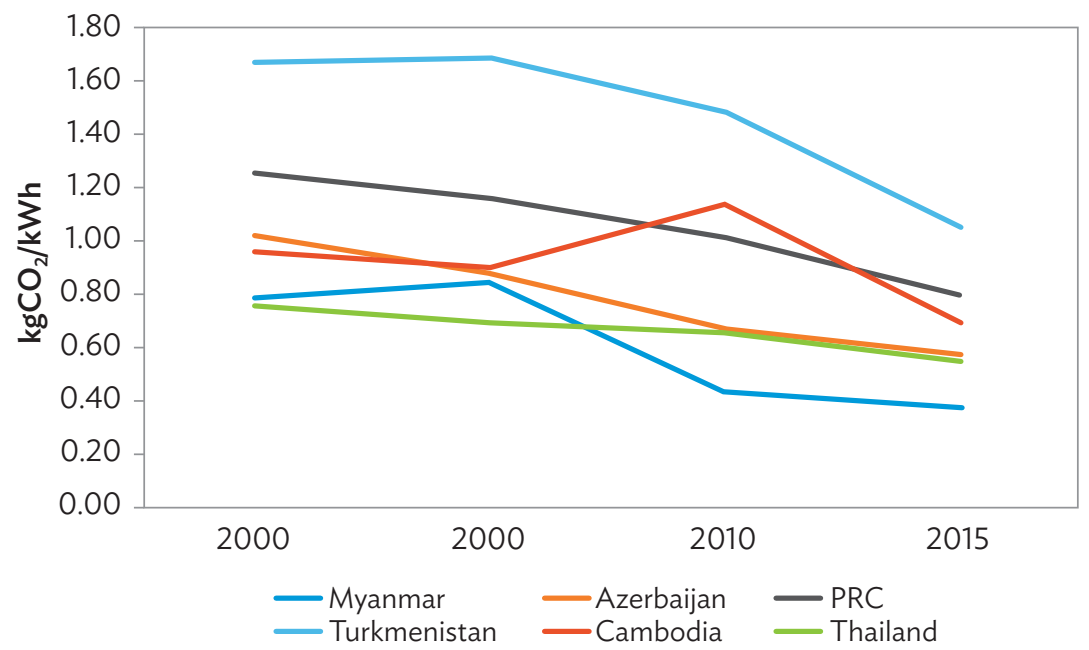

$\mathrm{ADB}=$ Asian Development Bank, IEA = International Energy Agency, $\mathrm{kgCO}_{2} \mathrm{e} / \mathrm{kWh}=$ kilogram of carbon dioxide per kilowatt-hour, PRC = People's Republic of China.

Note: Based on IEA data; all countries included have $>2 \%$ annual average reduction in the carbon grid factor.

Source: Grütter Consulting. 
Figure 27: ADB Developing Member Countries with a Slow Greening of the Electricity Grid

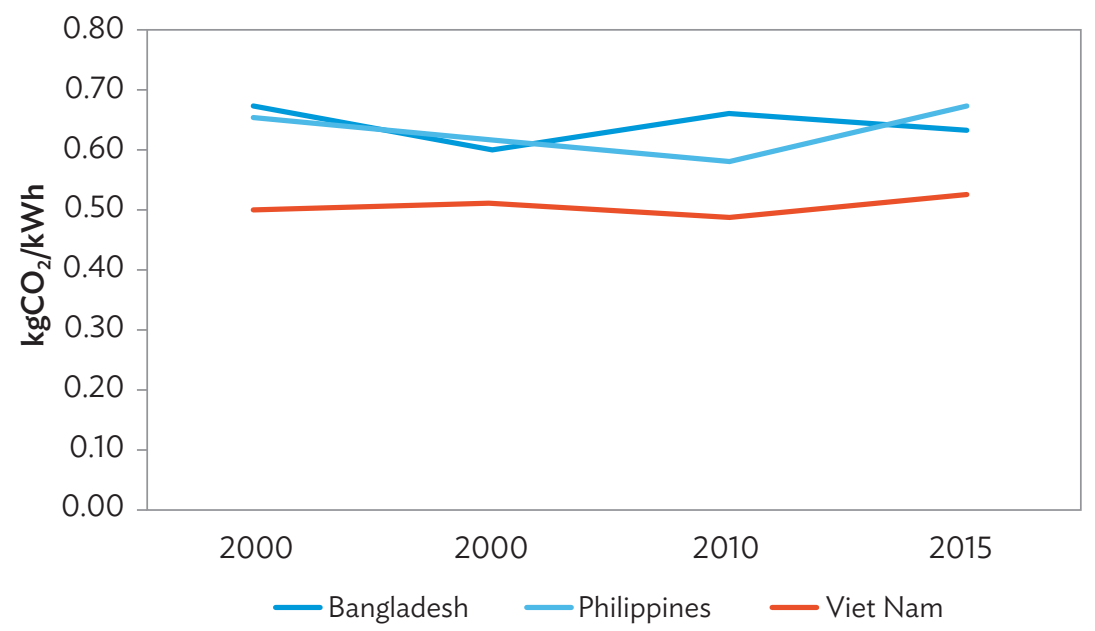

IEA = International Energy Agency, $\mathrm{kgCO}_{2} \mathrm{e} / \mathrm{kWh}$ = kilogram of carbon dioxide per kilowatt-hour. Note: Based on IEA data; all countries included have less than $0.5 \%$ annual average reduction in the grid factor.

Source: Grütter Consulting.

shows selected DMCs with a high speed of grid conversion (over $2 \%$ annual reduction in the carbon grid factor), while the figure thereafter shows countries with a low or even negative improvement rate. ${ }^{63}$

Grid transformation can be even faster in small island states with electricity production based on diesel and fuel oil. An example is Cook Islands, which had a grid factor of $0.86 \mathrm{kgCO}_{2} \mathrm{e} / \mathrm{kWh}^{64}$ in 2006 and $0.17 \mathrm{kgCO}_{2} \mathrm{e} / \mathrm{kWh}$ by end-2017, producing $80 \%$ of its electricity demand with renewables. The target is to produce $100 \%$ of electricity demand with renewables.

In assessing the effectiveness of promoting EVs in a given country, the current carbon factor of the grid as well as the improvement rate of the grid should be considered.

\subsubsection{Vehicle Manufacturing Emissions}

GHG emissions also result from the production of vehicles and their components, specifically from batteries in the case of EVs. Estimates of GHG emissions due to the production of batteries vary considerably with values ranging from $56-494 \mathrm{kgCO}_{2} \mathrm{e} / \mathrm{kWh}$, with an average of $110 \mathrm{kgCO}{ }_{2} \mathrm{e} / \mathrm{kWh}^{65}$ Intermediate fast-charging strategies (e.g., for buses or trucks) not only have a financial impact but also reduce the GHG footprint. However, the relevance of GHG emissions caused by battery production and their impact when comparing electric versus fossil fuel vehicles is reduced because batteries can be used for stationary applications after terminating their useful life span on the vehicle, especially for large

63 India has an average annual reduction rate of the grid factor of 1.5\% for the period 2000-2015.

64 NES, 2nd NC, 2011.

65 ICCT. 2018a. Effects of Battery Manufacturing on Electric Vehicle Life Cycle Greenhouse Gas Emissions. 
Figure 28: Life Cycle Emissions-Passenger Car and Bus

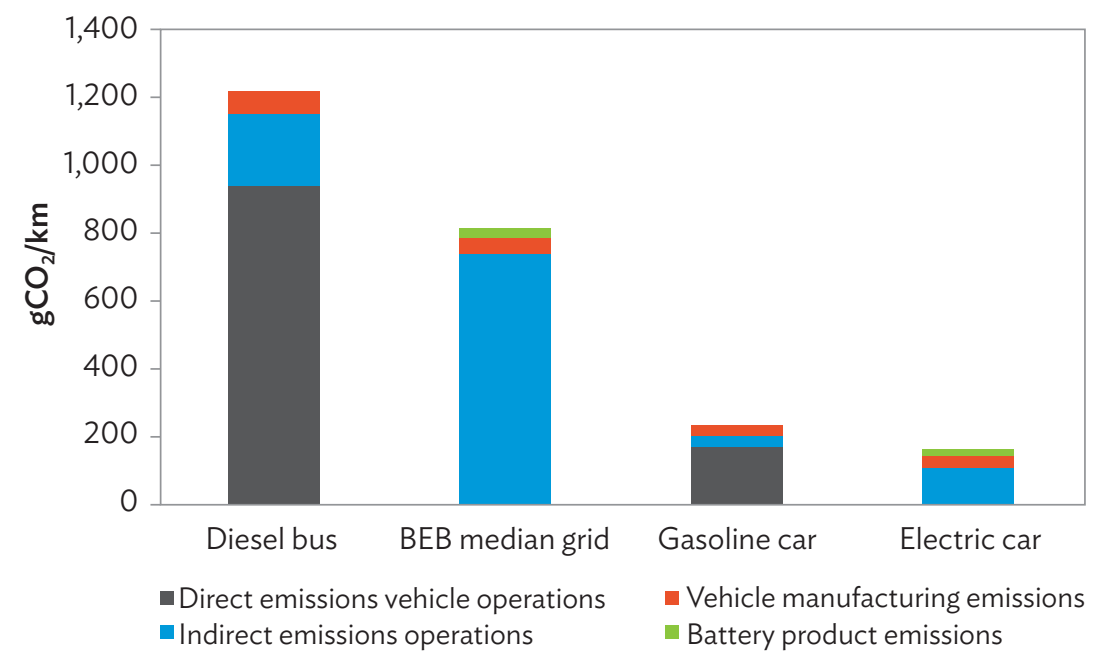

$\mathrm{BEB}=$ battery electric bus, $\mathrm{DMC}=$ developing member country, $\mathrm{EV}=$ electric vehicle, $\mathrm{GHG}=$ greenhouse gas, $\mathrm{kgCO}_{2} \mathrm{e} / \mathrm{kWh}=$ kilogram of carbon dioxide per kilowatt-hour.

Note: Based on a 12-meter standard urban diesel and EV bus with a battery set of $250 \mathrm{kWh}$; EV bus with $50 \%$ longer life span and battery usage on stationary applications for another 8 years (50\% of GHG emissions for battery applied to bus and $50 \%$ to stationary applications); passenger cars, gasoline and EV version with battery set of $30 \mathrm{kWh}$; median grid factor of DMCs of $0.655 \mathrm{kgCO}_{2} \mathrm{e} / \mathrm{kWh}$.

Source: Grütter Consulting.

battery sets from buses or trucks. The GHG manufacturing emissions of batteries thus need to be split up between vehicle and stationary applications. Also, EVs save on manufacturing upstream emissions, due to less consumption of other materials used for internal combustion engine manufacturing, less or no usage of oils and lubricants and, especially concerning buses, a longer life span due to less vibrations and longer-lasting engine parts.

Figure 28 compares approximate total life cycle GHG emissions per kilometer driven for a passenger car and a bus.

For buses (and trucks), upstream manufacturing-based emissions are of minor relevance with less than $5 \%$ of total GHG emissions for a diesel bus and less than $10 \%$ for a battery electric bus (BEB). The core emission factor remains the energy usage and associated upstream emissions of energy production. For passenger cars, the importance of upstream emissions is larger accounting for around $15 \%$ of GHG emissions for a gasoline car and $30 \%$ of GHG emissions for an electric unit. However, for passenger cars, the inclusion of upstream emissions does not change the overall picture of EVs resulting in GHG reductions and the most important component being the carbon factor of the grid. Figure 29 and Figure 30 compare for all vehicle categories the operational and battery production emissions over the lifetime of the vehicle using the average grid factor of Asian DMCs. It can be clearly seen for all vehicle categories that the battery emissions are a minor component, with operational emissions being clearly dominant. 
Figure 29: Greenhouse Gas Emissions Operations-Battery Buses, Urban Trucks, and Taxis

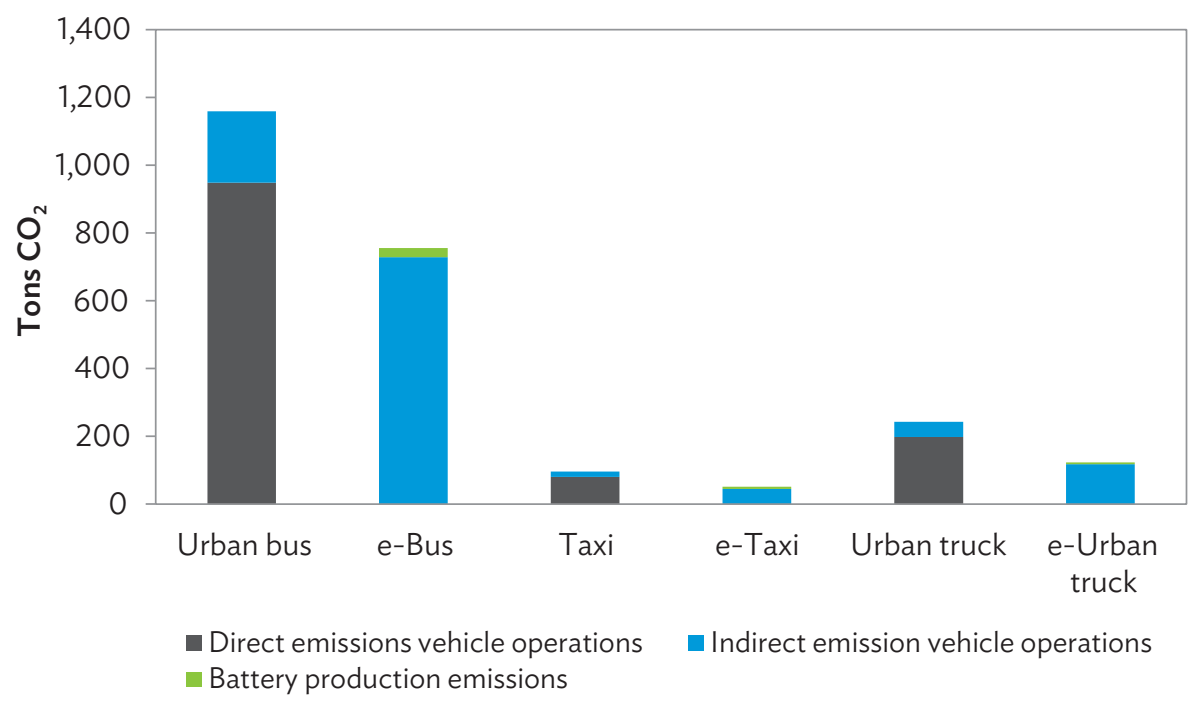

$\mathrm{DMC}=$ developing member country, $\mathrm{EV}=$ electric vehicle, $\mathrm{kgCO}_{2} \mathrm{e} / \mathrm{kWh}=$ kilogram of carbon dioxide equivalent per kilowatthour, $\mathrm{tCO}_{2} \mathrm{e}=$ ton of carbon dioxide equivalent.

Note: Based on a 12-meter standard urban diesel and EV bus with a battery set of $250 \mathrm{kWh}$; taxi diesel and EV version with battery set of $30 \mathrm{kWh}$; urban truck diesel and EV with battery set of $40 \mathrm{kWh}$; median grid factor of DMCs of $0.655 \mathrm{kgCO} \mathrm{e}_{2} \mathrm{e} / \mathrm{kWh}$.

Source: Grütter Consulting.

Figure 30: Greenhouse Gas Emissions Operations-Battery Cars, Motorcycles, and Rickshaws

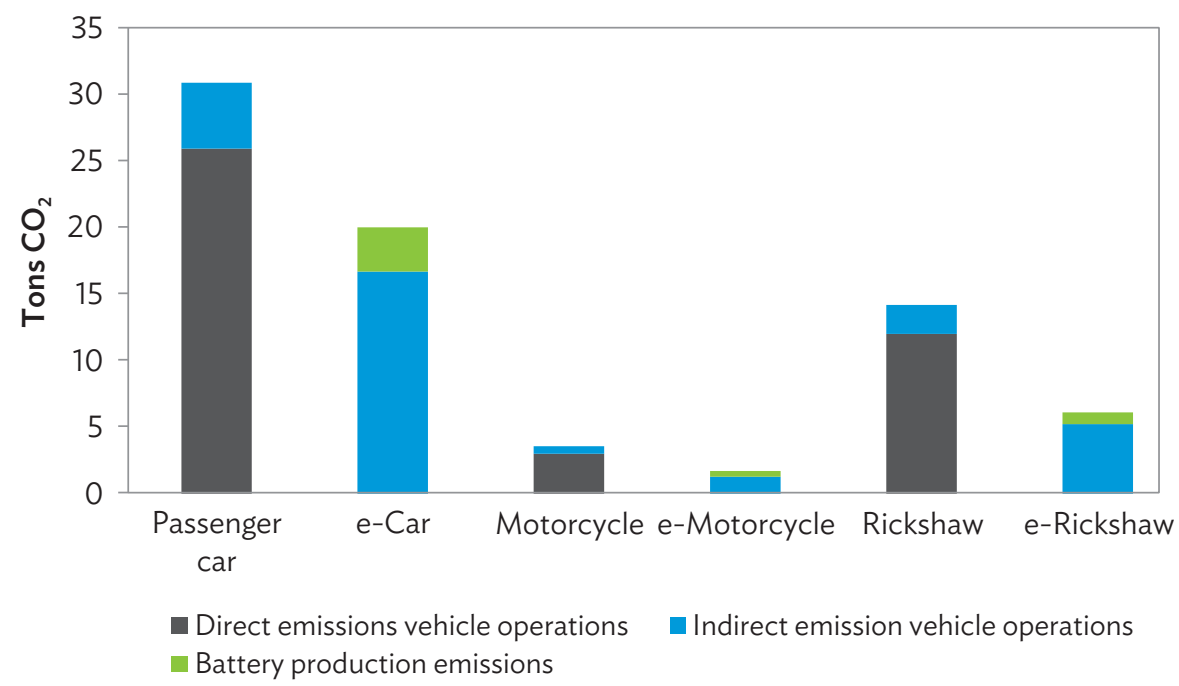

$\mathrm{CNG}=$ compressed natural gas, $\mathrm{DMC}=$ developing member country, $\mathrm{EV}=$ electric vehicle, $\mathrm{kgCO}{ }_{2} \mathrm{e} / \mathrm{kWh}=$ kilogram of carbon dioxide equivalent per kilowatt-hour, $\mathrm{tCO}_{2} \mathrm{e}=$ ton of carbon dioxide equivalent.

Note: Based on passenger cars gasoline and EV version with battery set of $30 \mathrm{kWh}$; motorcycle gasoline and $\mathrm{EV}$ with battery set of $4 \mathrm{kWh}$; CNG rickshaw and EV with battery set of $8 \mathrm{kWh}$; median grid factor of DMCs of $0.655 \mathrm{kgCO}{ }_{2} \mathrm{e} / \mathrm{kWh}$.

Source: Grütter Consulting. 


\subsection{Other Environmental Impacts}

\subsubsection{Air Pollution}

\section{Combustion-Related Emissions}

Historically, vehicle emission regulations are related to air pollutants. Poor air quality is detrimental to health with vehicle emissions being an important source of pollutants. The most common air pollutants are carbon monoxide, lead, ground-level ozone, particulate matter (PM), sulfur dioxide, and nitrogen dioxide. ${ }^{66}$ Ground-level ozone is not emitted directly into the air, but is created by chemical reactions between nitrogen oxide $\left(\mathrm{NO}_{x}\right)$ and volatile organic compounds in the presence of sunlight.

Lead and sulfur dioxide emissions are related to fossil fuel usage by vehicles and are controlled through the usage of unleaded gasoline and through maximum sulfur levels in fuels, primarily diesel. With the potential exception of Afghanistan and Myanmar, leaded fuel is not used anymore in Asian countries. ${ }^{67}$ Sulfur dioxide transport emissions result basically from diesel usage and are related to the sulfur contents of the fuel. Many countries in Asia, including the PRC and India, have introduced low (50 parts per million) and ultra-low (10-15 parts per million) sulfur diesel and eliminated the sale of high-sulfur diesel. Other countries still distribute 500 parts per million sulfur diesel and very few countries have even higher sulfur levels in their fuel.

The problem of carbon monoxide and hydrocarbon emissions, produced primarily by gasoline vehicles, has basically been resolved with the introduction of catalytic converters combined with unleaded fuel. Therefore, the main current problem of air pollution caused by transport is related to $P M$ and $\mathrm{NO}_{\mathrm{x}}$ emissions.

PM and $\mathrm{NO}_{\mathrm{x}}$ emissions are related to the emission standard of the vehicle. Table 6 gives an overview of the current emission standard for road vehicles enforced in DMCs of ADB.

Table 6: Vehicle Emission Standards in ADB Developing Member Countries

\begin{tabular}{ll}
\hline Vehicle Emission Standard & \multicolumn{1}{c}{ Countries } \\
\hline No standard or Euro 0/1 & Afghanistan, Cambodia, Lao PDR, Myanmar, Turkmenistan \\
Euro 2 & Bangladesh, Mongolia, Pakistan \\
Euro 3 & Nepal, Uzbekistan \\
Euro 4 & Azerbaijan, Bhutan, India, Indonesia, Malaysia, Philippines, Sri Lanka, Tajikistan, Thailand, \\
& Viet Nam \\
Euro 5 & Armenia, Georgia, Kazakhstan, Kyrgyz Republic, PRC \\
\hline
\end{tabular}

Lao PDR = Lao People's Democratic Republic, PRC = People's Republic of China.

Note: National emission standards (e.g., PRC standard or Bharat standard used in India) have been related to the equivalent Euro standard.

Source: Grütter Consulting, based on multiple sources.

66 United States Environmental Protection Agency. Criteria Air Pollutants. https://www.epa.gov/criteria-air-pollutants.

67 Worldatlas. Countries that still use leaded gasoline. https://www.worldatlas.com/articles/countries-that-still-use-leadedgasoline.html (accessed 18 October 2018); however, Stratas Advisors confirmed lead phase out in Myanmar in 2016. 
A large number of countries in Asia are applying Euro 4 or Euro 5 standards while others have Euro 2 or Euro 3 levels or no standard at all (which, in practice, basically results in Euro 2 vehicles as older units are not anymore produced). Figure 31, Figure 32, and Figure 33 show for the different vehicle categories the air pollution impact for $\mathrm{NO}_{\mathrm{x}}$ and $\mathrm{PM}_{2.5}$ of EVs compared to Euro 2 and Euro 4 units. Electric units in all cases have zero exhaust emissions. ${ }^{68}$

Heavy-duty vehicles clearly have significantly more emissions than light vehicles. A CNG urban bus Euro 2 has 65 times more emissions than a same emission standard gasoline passenger car. With Euro 4 standards, the difference gets smaller, but is still around factor 10 comparing, e.g., a diesel passenger car with a diesel bus. Considering the much higher mileage and the longer life span of commercial vehicles, it is obvious that air quality impacts will basically be derived from heavy-duty vehicles. Also notable is that diesel passenger cars have 3 (Euro 2) to 10 times (Euro 4) more emissions than gasoline units.

With Euro 4, differences between light and heavy vehicles are relatively small. The core parameter is the fuel type used with diesel vehicles having significant $\mathrm{PM}_{2.5}$ emissions while gasoline- and CNG-powered units have minor emission levels.

In summary, EVs can have an important local pollution impact. However, the magnitude will depend largely on the emission standards of the country and the type of vehicle replaced (fuel type and vehicle category). In general, it can be stated that pollution impacts will be significant if urban buses or diesel passenger cars (used often as taxis) are replaced, while the impact on air quality from using EVs will

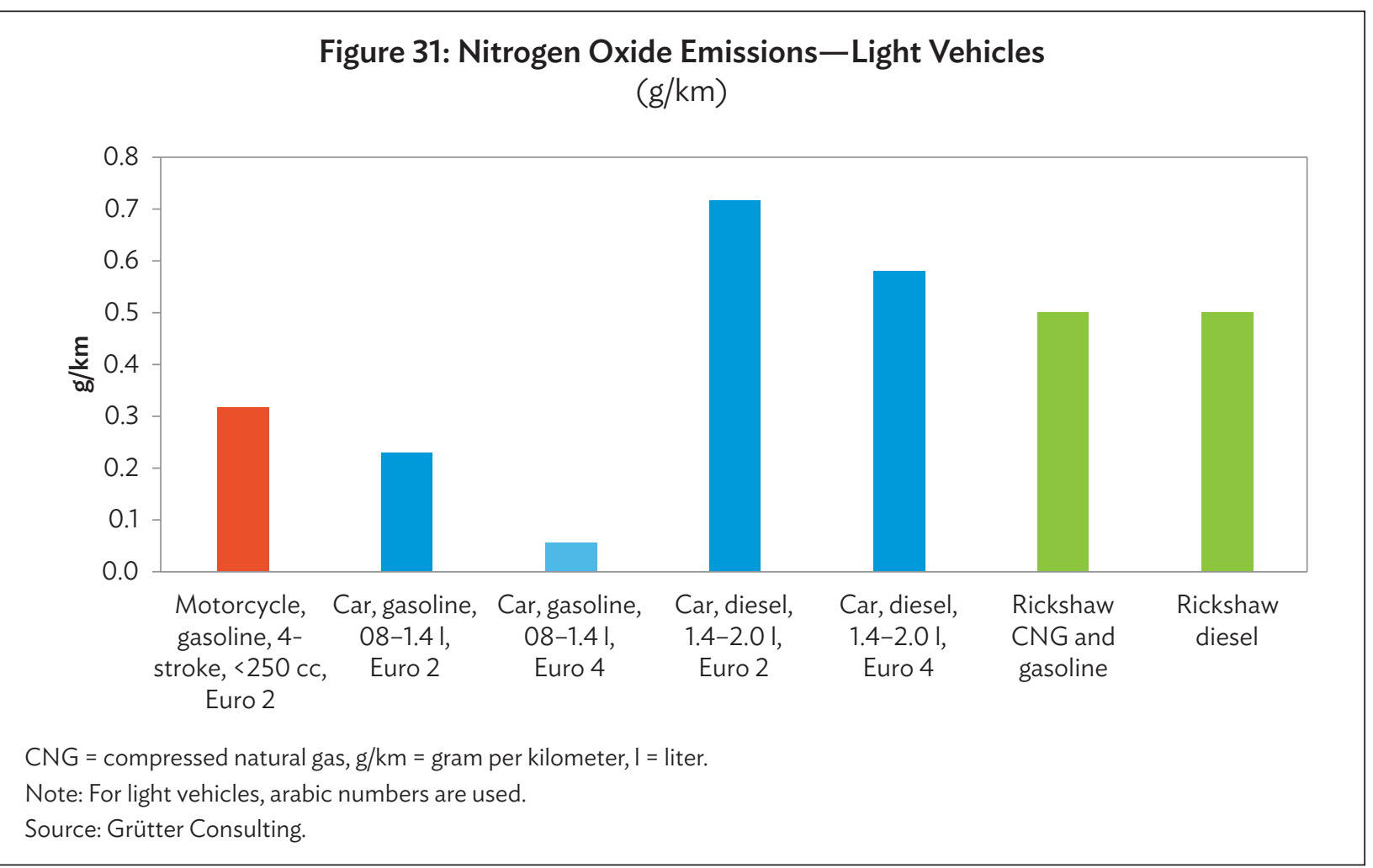

68 Gasoline 4-stroke motorcycles; figures based on data EEA, 2016a, COPERT model for motorcycles and cars and lyer (2012) and Grieshop (2012) for rickshaws. 
Figure 32: Nitrogen Oxide Emissions-Heavy Vehicles

$(\mathrm{g} / \mathrm{km})$

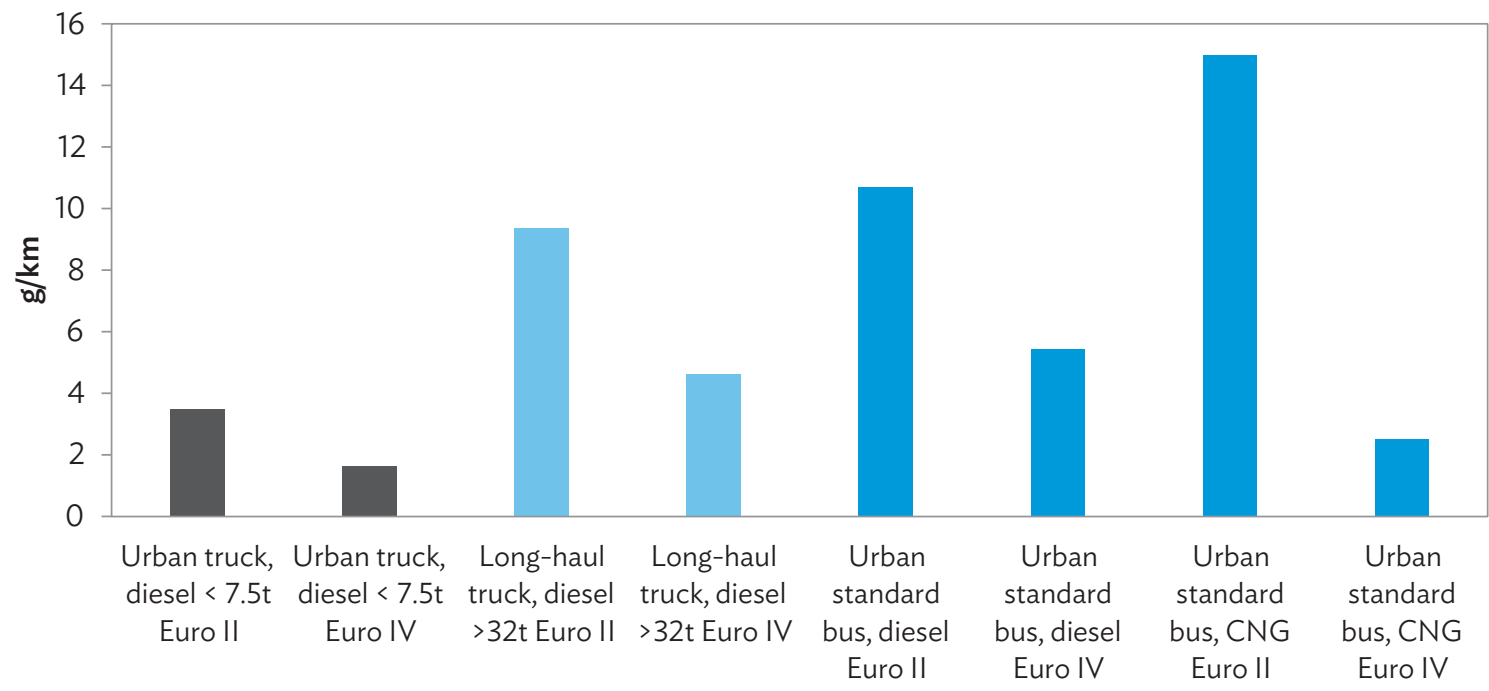

$\mathrm{CNG}=$ compressed natural gas, EEA = European Environmental Agency, g/km = gram per kilometer.

Note: Diesel, CNG, gasoline; for heavy-duty vehicles, Roman numbers are used.

Source: EEA. 2016. Air Pollutant Emission Inventory Guidebook Version 2016 Update. December; COPERT model.

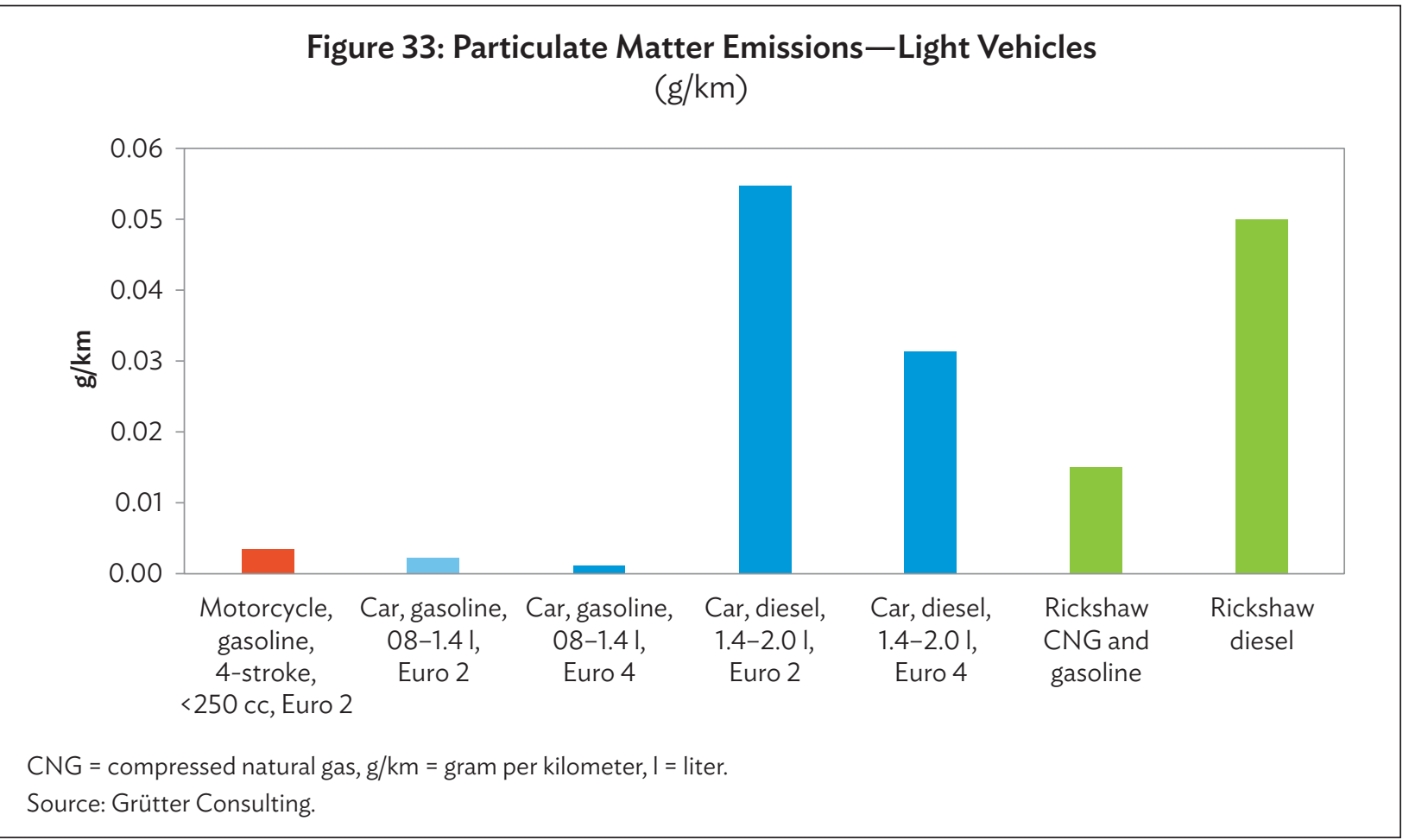




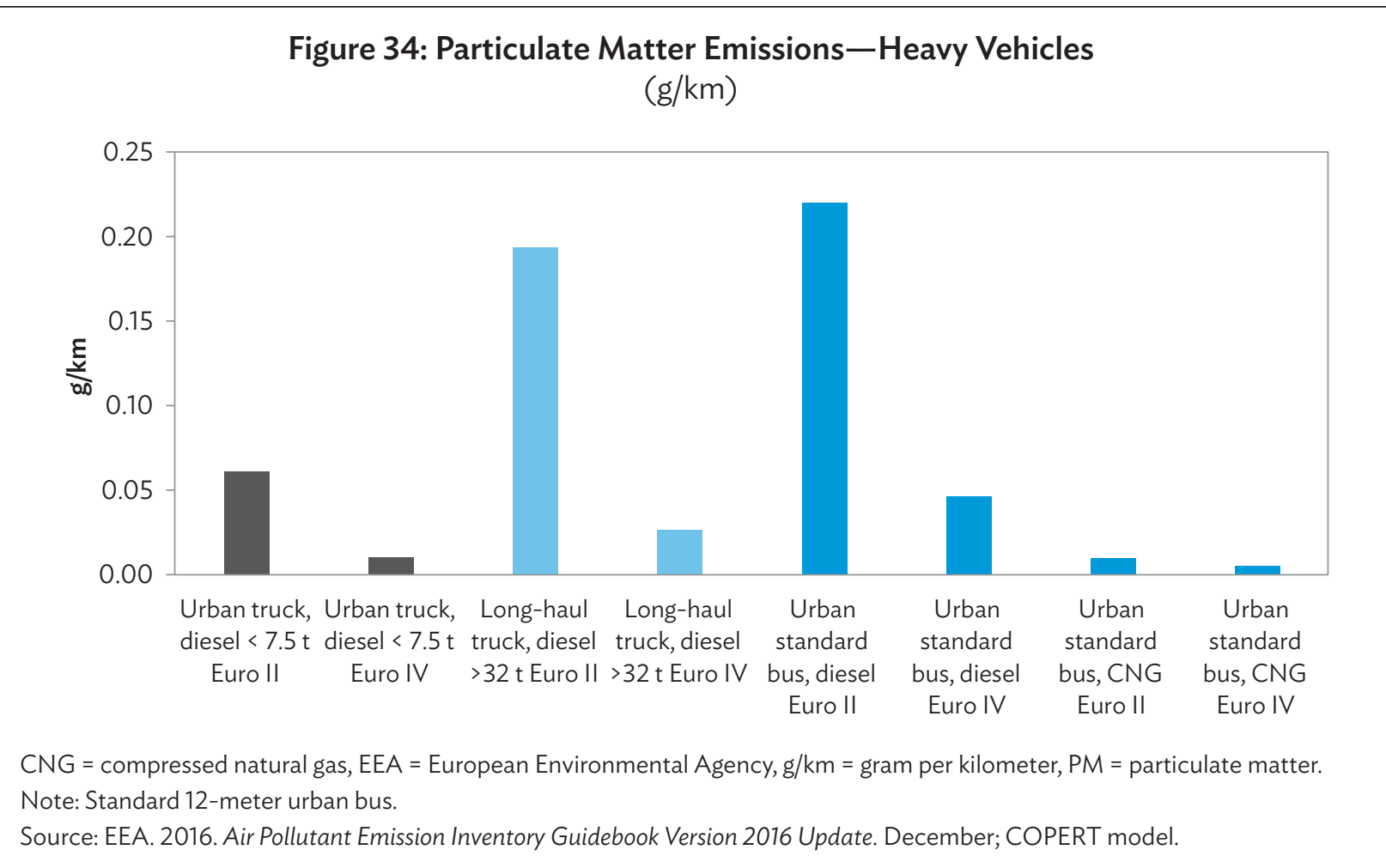

be minor if emission standards are Euro 4 and above and if the focus is on motorcycles and gasoline passenger cars.

\section{Non-Combustion Emissions of Local Pollutants}

Vehicles not only have combustion emissions, but also PM emissions from brake, tire, and particle re-suspension. Measurements of $\mathrm{PM}_{10}$ in the city of Zurich, Switzerland in 2007, for example, showed that $16 \%$ of PM emissions from heavy-duty vehicles in urban areas were brake, $53 \%$ re-suspension, and only $31 \%$ combustion-related. ${ }^{69}$ In urban settings, measurements made by the UK Transport Research Laboratory (TRL), ${ }^{70}$ the California Environmental Protection Agency Air Resources Board, ${ }^{71}$ and the European Environment Agency $(E E A)^{72}$ all estimate that $\mathrm{PM}_{2.5}$ emissions from braking and tires of heavy-duty vehicles are, for Euro IV and subsequent emission standards, higher than those of combustion emissions. However, there are no available data comparing non-combustion emissions of EVs with those of conventional units. Presumably, EVs would have lower brake abrasion emissions due to usage of regenerative braking, but higher tire-based emissions (EVs have a higher tire usage due to sharper braking and acceleration and higher weight). Cumulatively, it is expected that EVs have lower non-combustion emissions due to the dominance of brake abrasion emissions within non-combustion emission sources-however, there is a lack of monitored data in this area.

69 BAFU. 2009. PM-10 Emissionsfaktoren von Abriebspartikeln des Strassenverkehrs (APART). Bern.

70 TRL. 2014. Briefing Paper on Non-Exhaust Pemissions from Road Transport.

71 CARB. 2015. EMFAC2014 Volume III - Technical Documentation.

72 EEA. 2016b. Road Vehicle Tyre and Brake Wear. 
Figure 35: External Noise Levels of a Bus When Departing from the Bus Stop

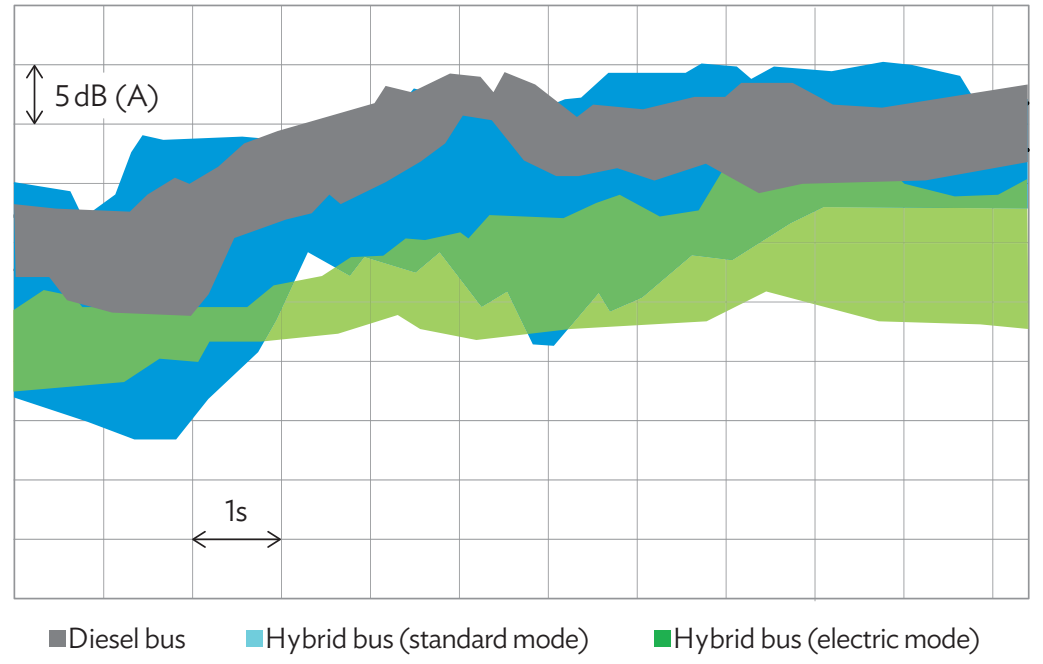

$\mathrm{dB}=$ decibel.

Source: M. Faltenbacher et al. 2011. Abschlussbericht Plattform Innovative Antriebe Bus. Auftraggeber

Bundesministerium für Verkehr, Bau und Stadtentwicklung.

\subsubsection{Noise}

EVs have significantly lower noise levels, especially during the start-and-stop process and at low speeds where engine noise dominates. ${ }^{73}$ Figure 35 shows the noise level measured from the outside in the process of starting the bus from a stop.

\section{ELECTRIC VEHICLE ECONOMICS}

\subsection{Profitability of Electric Vehicles}

The profitability of EVs will depend on national price levels and cannot be determined in a general form. The significant up-front subsidies from countries with high EV numbers are a clear indication that EVs are currently not profitable. Norway, with the highest EV penetration rate, subsidizes $45 \%$ of the EV price and the People's Republic of China (PRC), with the largest number of electric cars, subsidizes 23\% of the total price while also giving numerous other benefits. ${ }^{74}$ The PRC has more than $95 \%$ of electric buses (e-buses) operating worldwide and subsidizes, on average, $65 \%$ of the purchase cost making them cheaper than fossil fuel units. ${ }^{75}$ The purchase cost is not the only barrier, but it is still the barrier cited most by potential EV customers. ${ }^{76}$ In the following sections, core parameters which determine the relative profitability of EVs will be discussed, including the capital expenditure (CAPEX) for the vehicle, and the CAPEX of the infrastructure, energy prices, and maintenance costs.

73 Electric buses, for example, have noise reductions of around $10 \mathrm{~dB}$ compared to diesel units (http://news.emove360.com/ public-comparison-e-bus-much-quieter/?lang=e).

74 McKinsey. 2017d. Dynamics in the Global Electric-Vehicle Market.

75 Grütter Consulting. 2018. Low Carbon Buses in PRC.

76 McKinsey. 2017a. Electrifying Insights: How Automakers Can Drive Electrified Vehicle Sales and Profitability. 


\subsection{Capital Expenditure-Vehicle}

The cost of an $\mathrm{EV}$ can be broken down largely into the cost of its battery (40\%-50\%), electric power train (about 20\%), and other elements of the vehicle itself (30\%-40\%). ${ }^{77}$ The CAPEX of EVs is significantly higher than of conventional vehicles. Also, many EVs will require battery replacement (especially buses and trucks) during their commercial lifetime, thus incurring significant replacement investment during the vehicle life span. An important source for CAPEX differentials is battery costs (see Figure 36 for passenger cars).

The expected sharp decline of battery costs will help to significantly decrease the CAPEX gap between EVs and conventional vehicles.

Not only has the battery cost per kilowatt-hour ( $\mathrm{kWh}$ ) declined, but at the same time, the battery energy density has increased and the vehicle efficiency has increased. This results in either longer driving ranges with the same battery pack or a smaller battery pack, thus reducing vehicle costs beyond the battery cost reduction per $\mathrm{kWh}$. Another important component is that fast-charging options have increased strongly with much lower cost and a higher power output of fast chargers, thus allowing vehicles to use smaller battery packs with more frequent intermediate fast-charging. Also, battery manufacturers are now guaranteeing higher state of charge (SOC) over a longer period of time, i.e., battery replacement is not required as frequently, again reducing CAPEX lifetime costs. These market trends together will significantly reduce CAPEX differentials between electric and fossil fuel vehicles.

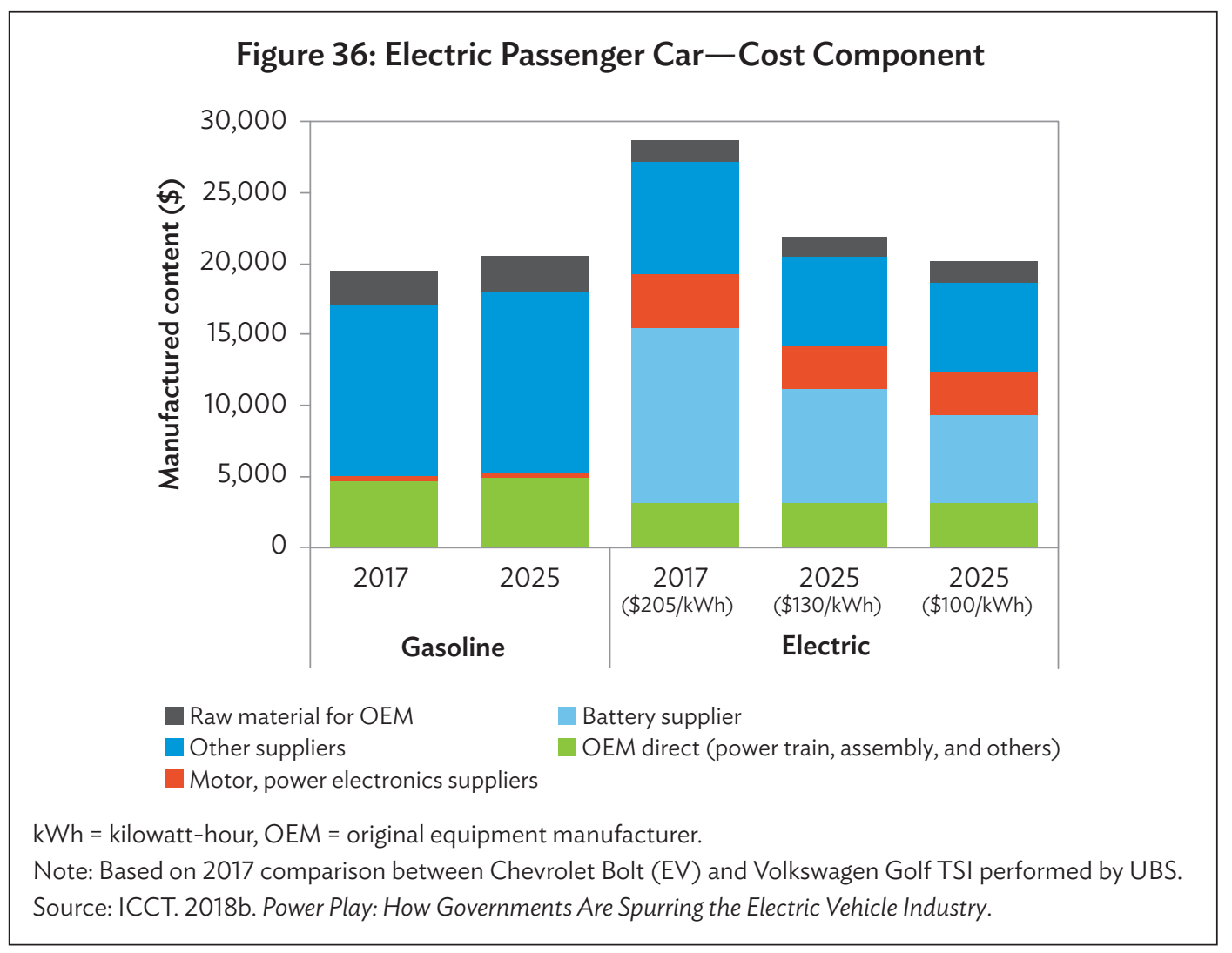

77 McKinsey. 2018b. Three Surprising Resource Implications from the Rise of Electric Vehicles. 


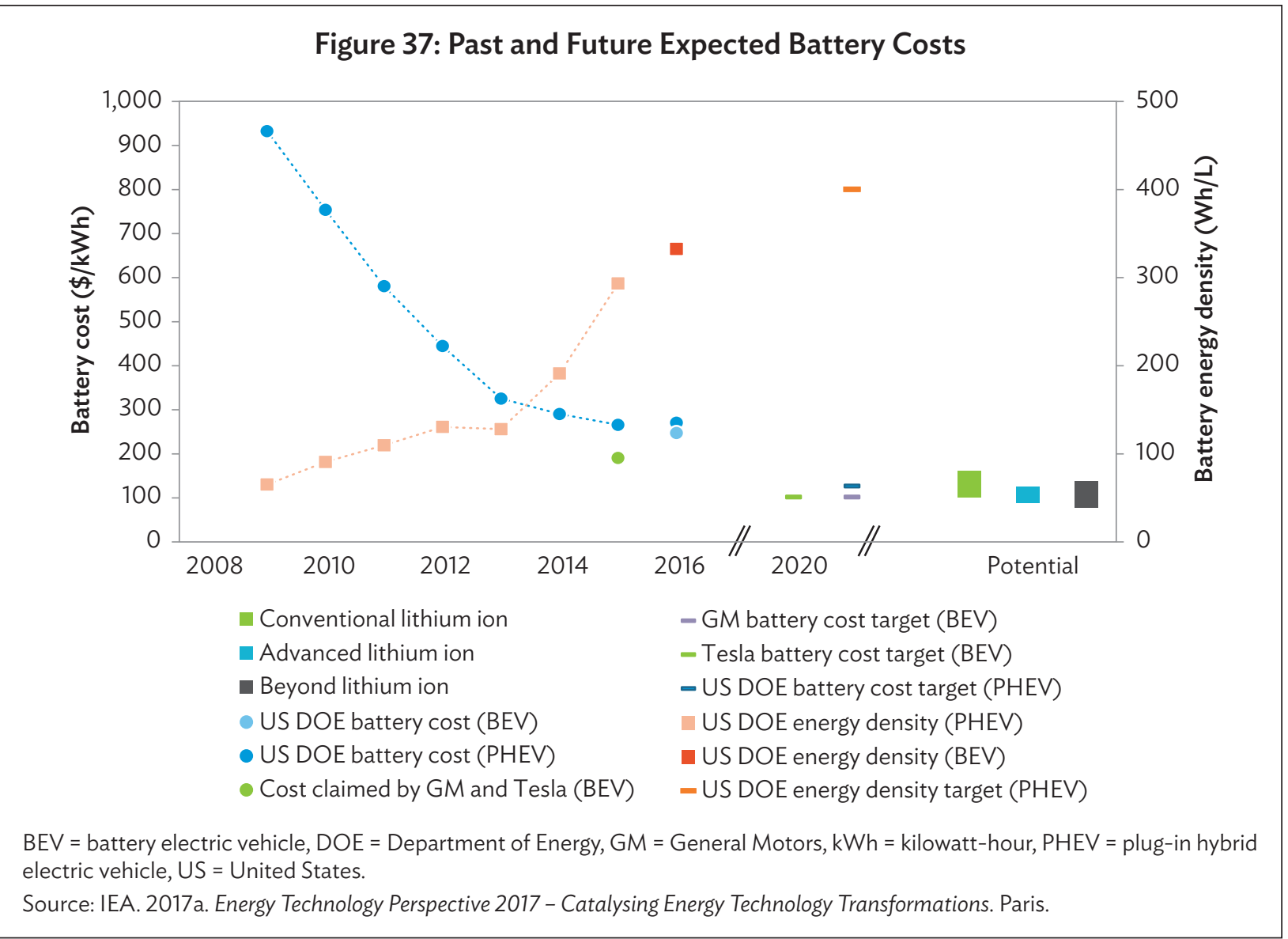

A policy used by many countries to promote EVs is to reduce vehicle taxes. In general, this favors passenger cars while commercial vehicles, including buses and taxis, already often have very low taxes, if at all. From an economic perspective, tax reductions are comparable to subsidies. However, direct subsidies would be more efficient compared to tax reductions as they do not discriminate between vehicle categories, i.e., not only highly taxed passenger cars would profit, but all types of EVs.

A higher CAPEX of the vehicle can be recovered either through (i) lower operational expenditures (OPEX) and/or (ii) a longer lifetime of the vehicle. In the case of buses, for example, batteries are guaranteed as of 2018 by most manufacturers for 8 years with a SOC of $80 \%$. E-buses have a longer technical life span than conventional buses due to fewer parts and less vibration compared to fossil fuel units. They could be operated without any problems from 15 to 20 years (at twice the battery life span), while fossil fuel buses are often replaced after $10-12$ years of operations. ${ }^{78}$

\subsection{Capital Expenditure-Infrastructure}

Charging systems are vital for EV deployment. Charging speeds continue to become faster and charger costs are dropping. There are huge differences in charging systems, especially for buses and trucks,

78 Even if many developing countries operate them more than 12 years, this might not be the financially optimal strategy as maintenance and standstill costs increase sharply after more than 1 million $\mathrm{km}$ of usage. 
between slow chargers and vehicles stacked with batteries and ultra-fast or continuous charging inductive, via overhead wire ${ }^{79}$ or via rail and a minimum on-board battery capacity.

Urban public transport projects which want to electrify operations must assess carefully all available options to identify the optimal technical and financial solution, e.g., a BRT route with articulated buses might be much more apt for trolleybuses, or ultra-fast opportunity charge systems, which reduce bus costs and allow for lighter and more efficient vehicles, while mixed traffic operations with smaller buses might be better off with battery electric buses (BEBs) and slow charging overnight. The optimal solution will also depend on electricity consumption and power charges (see Chapter 7).

Another important component is how electric infrastructure is financed. Up-front subsidies have been used in many countries to provide for the charging infrastructure and to also overcome the dilemma of having too few EVs to warrant the cost of a charging network while people do not purchase EVs unless there is an existing charging network. Financing options for charging systems include (i) additional service fee by EV owners on top of the payment for electricity consumption, (ii) payment for the electric infrastructure by all household consumers, or (iii) payment for the infrastructure through public funding. Spreading the cost to include not only direct EV users can be justified by the environmental benefits (i.e., basically improved air quality, reduced noise, and less global warming). This is especially true for an urban public transport charging infrastructure from which all urban residents profit and, therefore, spreading the cost to all households can be justified.

\subsection{Operational Expenditure}

Differences in OPEX between EVs and conventional vehicles are influenced by the following major components:

- relative energy costs between using electricity and fossil fuels,

- energy efficiency of the vehicle,

- maintenance costs, and

- lifetime mileage of the vehicle.

EVs in general have lower maintenance costs due to less liquids, fewer pre-emptive inspections, and less wear and tear on mechanical parts that require replacement (including brake pads). However, tire usage for $\mathrm{EVs}$ is $20 \%-30 \%$ higher due to increased weight and faster acceleration and de-acceleration, ${ }^{80}$ spare parts tend to be more expensive (due to lack of a secondary spare parts market), standstill times are often longer, and maintenance tends to be more expensive due to higher skills qualifications required. Overall maintenance cost of EVs is around $60 \%-80 \%$ higher than conventional vehicles. ${ }^{81}$

Maintenance cost, however, is not much of a factor because it accounts for a much smaller fraction of OPEX than energy cost (Figure 38). ${ }^{82}$

79 Not only trolleybuses; for example, see Siemens and e-highways at Siemens AG. eHighway - Solutions for electrified road freight transport. https://www.siemens.com/press/en/feature/2015/mobility/2015-06-ehighway.php.

80 Grütter Consulting. 2018a. Low Carbon Buses in PRC, for buses or UBS. 2017. UBS Evidence Lab Electric Car Teardown Disruption Ahead?, for e-cars.

81 For example, see UBS. 2017. UBS Evidence Lab Electric Car Teardown - Disruption Ahead?, for maintenance cost comparison passenger cars, excluding tires or Grütter Consulting. 2018. Low Carbon Buses in PRC, for maintenance savings of e-buses.

82 Similar relations of OPEX costs are also found for passenger cars; for example, see Harrison, P. 2018. Fuelling Europe's Future: How the Transition from Oil Strengthens the Economy, Figure 6. 
Figure 38: Comparison of Total Cost of Ownership of Buses in the People's Republic of China $(\$ / \mathrm{km})$

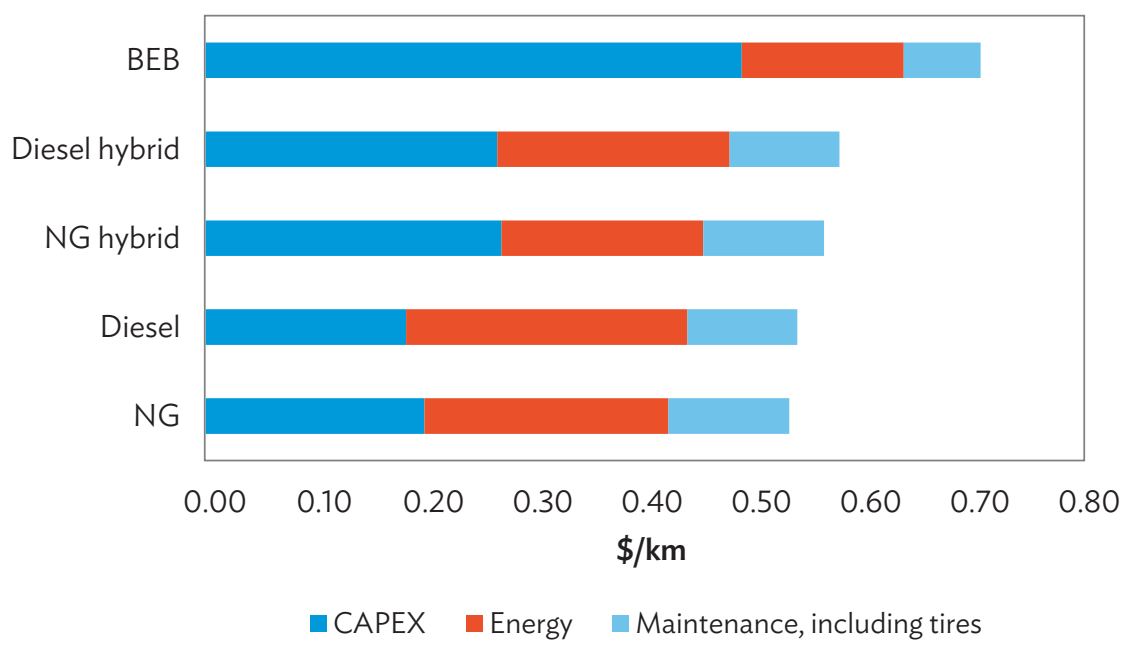

$\mathrm{BEB}=$ battery electric bus, $\mathrm{CAPEX}=$ capital expenditure, $\mathrm{km}=$ kilometer, $\mathrm{NG}=$ natural gas, $\mathrm{OPEX}=$ operational expenditure, PRC = People's Republic of China.

Source: ADB. 2018. Sustainable Transport Solutions: Low-Carbon Buses in the People's Republic of China. Manila, based on average CAPEX and OPEX of bus operators in 16 PRC cities.

Figure 39: Fossil Fuel Prices in ADB Developing Member Countries, as of June 2018 $(\$ /$ liter )

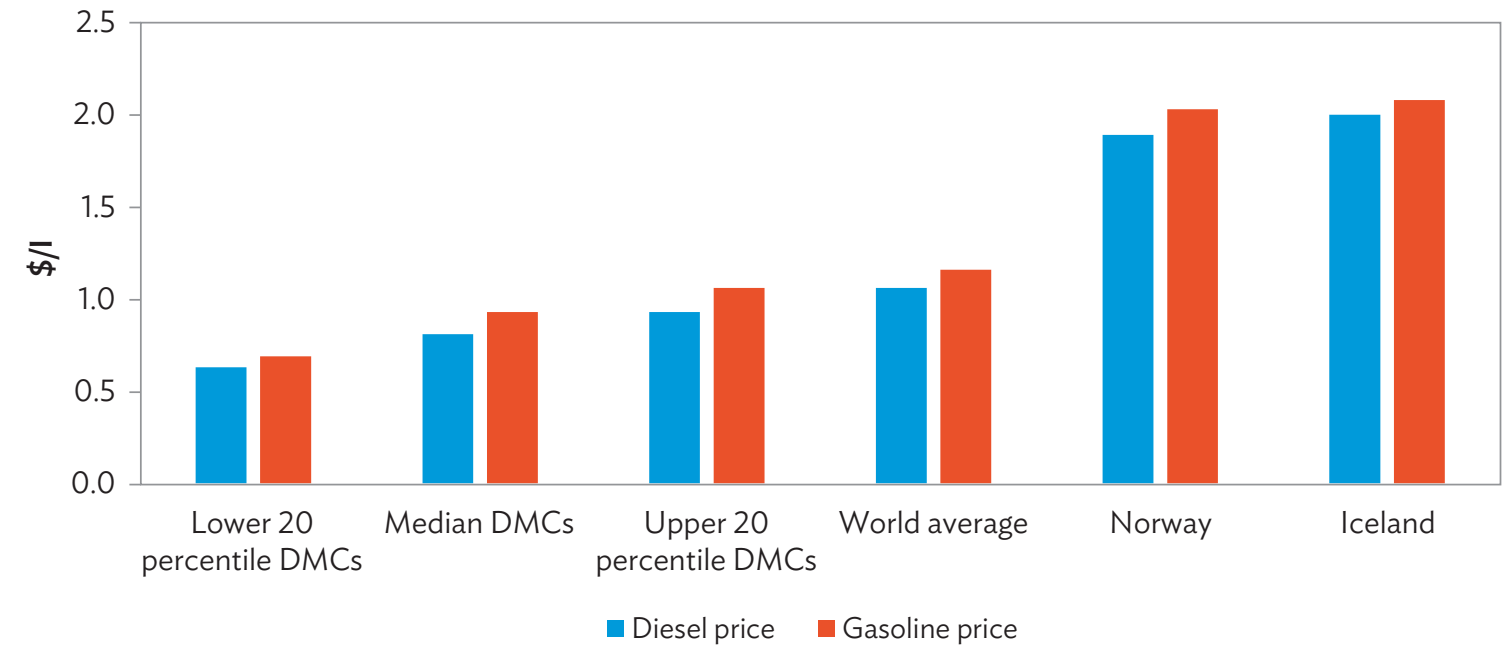

DMC = developing member country, $\$ / I=$ United States dollar per liter.

Source: Grütter Consulting. 
Table 7: Average Fossil Fuel Prices of ADB Developing Member Countries, as of June 2018 (\$/liter)

\begin{tabular}{ll}
\hline Fossil Fuel Prices & \multicolumn{1}{c}{ Countries } \\
\hline $\begin{array}{l}\text { Low gasoline and diesel prices (lower 20\% of } \\
\text { countries): average price }<0.65 \$ / \text { liter }\end{array}$ & Azerbaijan, Kazakhstan, Malaysia, Myanmar, Turkmenistan, Uzbekistan \\
$\begin{array}{ll}\text { Moderate gasoline and diesel prices: average } \\
\text { price }>0.65 \$ / \text { liter and }<0.96 \$ / \text { liter }\end{array}$ & $\begin{array}{l}\text { Afghanistan, Armenia, Bangladesh, Bhutan, Fiji, Indonesia, Kyrgyz Republic, } \\
\text { Mongolia, Nepal, Pakistan, Philippines, Sri Lanka, Tajikistan, Viet Nam }\end{array}$ \\
$\begin{array}{ll}\text { High gasoline and diesel prices (upper 20\% of } \\
\text { countries): average price }>0.96 \$ / \text { liter }\end{array}$ & $\begin{array}{l}\text { Cambodia, Georgia, India, Lao People’s Democratic Republic, People’s } \\
\text { Republic of China, Thailand }\end{array}$ \\
\hline
\end{tabular}

Source: Grütter Consulting, based on average of diesel and gasoline prices primarily sourced from Global Petrol Prices. https://www. globalpetrolprices.com/.

\section{Box 3: Optimization of E-Bus Configuration}

The bus operator wants to achieve the lowest total cost of ownership for electric buses (e-buses). E-bus technologies range from buses with large battery sets and slow charging overnight, to fast plus slow charging with a medium battery set to opportunity charging with a small battery set. The following table shows as example a typical electricity price situation.

\begin{tabular}{lcc}
\hline Parameter & Unit & Value \\
\hline Electricity price night & $\$ / \mathrm{kWh}$ & 0.05 \\
Electricity price off-peak & $\$ / \mathrm{kWh}$ & 0.08 \\
Electricity price peak & $\$ / \mathrm{kWh}$ & 0.15 \\
Electric power demand charge night per month & $\$ / \mathrm{kW}$ & 5.0 \\
Electric power demand charge off-peak per month & $\$ / \mathrm{kW}$ & 7.0 \\
Electric power demand charge peak per month & $\$ / \mathrm{kW}$ & 12.0 \\
Number of hours night tariff & hours & 10 \\
Number of hours off-peak tariff & hours & 10 \\
Number of hours peak tariff & hours & 4 \\
\hline
\end{tabular}

Based on the electricity consumption of the bus fleet and the chargers required an electricity cost of $0.10 \$ /$ kilowatt-hour ( $\mathrm{kWh}$ ) for overnight charging, $0.13 \$ / \mathrm{kWh}$ for a mixture of slow charging and fast charging during off-peak periods in the day and $0.21 \$ / \mathrm{kWh}$ for an opportunity charge system results. However, the option with the lowest electricity cost has the highest bus capital expenditure (CAPEX) due to a larger battery stack (350 kWh of batteries on-board the bus instead of $175 \mathrm{kWh}$ with a mixed system). Based on annualized total costs, the most cost-efficient option is the mixed system with slow charging during the night and fast charging during the day, followed by an opportunity charge system; and the costliest system was slow charging during the night. The ranking is different for each city and also changes over time as it is dependent on the electricity price structure, charging infrastructure cost, and battery costs. The critical point is that, in contrast to conventional vehicles, fleet managers must realize an integral analysis to identify the most cost-effective solution as electricity has not one fixed and constant cost.

Source: Grütter Consulting.

The largest savings of EVs relative to conventional vehicles is based on energy usage. Savings depend on fossil fuel cost, electricity cost, and mileage driven. Table 7 shows average fossil fuel costs in DMCs and relates them to the world market average as well as the fossil fuel prices paid in Norway and Iceland, which have very high EV penetration rates. 
Projections of fossil fuel prices are important in this context. But it is difficult to forecast oil prices, thus making it also difficult to estimate total cost of ownership (TCO) based on fuel usage as this depends considerably on future fossil fuel prices. However, it is clear that high fossil fuel prices create a significant incentive to invest in EVs. Table 7 groups countries based on average fossil fuel prices. ${ }^{83}$

Electricity prices are far more complex to determine as they depend on the time the vehicle is charged and the power charge. Depending on the system configuration, electricity costs for an EV can vary by factor 3 (Box 2).

\subsection{Lifetime Cost Comparison}

Lifetime mileage is an important aspect when considering EV profitability. EVs have lower OPEX and higher CAPEX. A high mileage will thus favor cost recovery. Figure 40 shows average CAPEX and OPEX lifetime costs for most common vehicle categories and compares non-discounted TCO between conventional vehicles and EVs.

For e-motorcycles and e-rickshaws, the purchase price is typically comparable to a conventional vehicle. However, the short battery life span of 1 year (for lead-acid batteries) or 2-3 years for lithium-ion batteries result in high replacement investments during the vehicle life span, increasing total CAPEX (calculated based on total investment over vehicle lifetime, i.e., including battery replacement investments).

E-motorcycles and e-rickshaws have lower TCO than conventional units-however, in these two vehicle categories, and differences in convenience (and perception) between EVs and conventional units can be significant, e.g., higher speed, longer range, more passenger capacity, and better durability of conventional vehicles is often mentioned as argument for not purchasing EVs.

Conventional passenger cars clearly have lower TCO than EVs. However, if an EV is used as a taxi, the $\mathrm{TCO}$ is better than a conventional unit due to higher lifetime mileage. In terms of lifetime vehicle mileage, there are financial benefits to operating EVs as taxis (or for car-sharing programs) than conventional units.

E-buses and urban electric trucks, in general, have higher TCO than conventional units. However, TCO can be comparable to conventional units (i) if maintenance costs are lower, (ii) if the commercial lifetime of the $\mathrm{EV}$ is longer, and (iii) if battery stacks are optimized by recharging the vehicle quickly during the day.

\subsection{Monetizing Environmental Benefits}

Potential environmental benefits from using EVs are basically related to reduced greenhouse gas (GHG) emissions and air pollutants as well as reduced noise levels. Accident rates or other factors are not directly influenced by EVs. The impact in economic terms of reduced air pollution is related to the magnitude of reductions (in tons) and the economic cost of the pollution. The average unit cost per pollutant varies per country as it is relative to the ground-level local pollution levels and the health impact and costs caused. ${ }^{84}$

83 Average between gasoline and diesel.

84 IMF. 2014. Getting Energy Prices Right. Washington, DC. This is based on determining the pollution exposure of the population and how the additional pollution exposure increases mortality risks using concentration response functions relying primarily on work realized by the World Health Organization's Global Burden of Disease project. Mortality risks or more precisely the value per premature death avoided are valuated economically based on stated preference studies realized by the OECD. 
Figure 40: Total Cost of Ownership between Conventional and Electric Vehicles

(\$)

Motorcycle

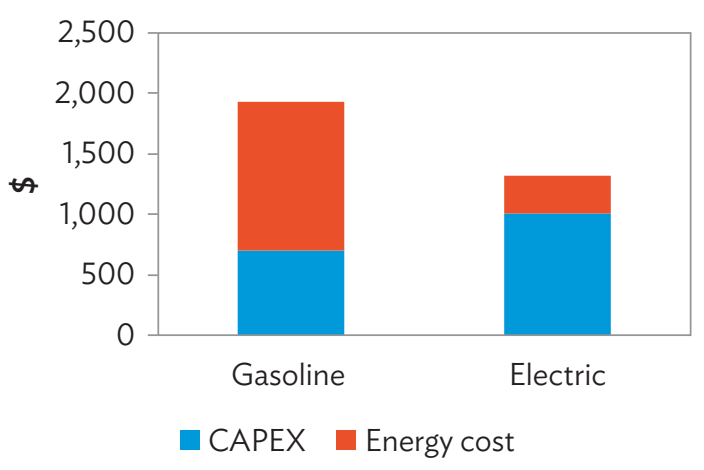

Passenger Car

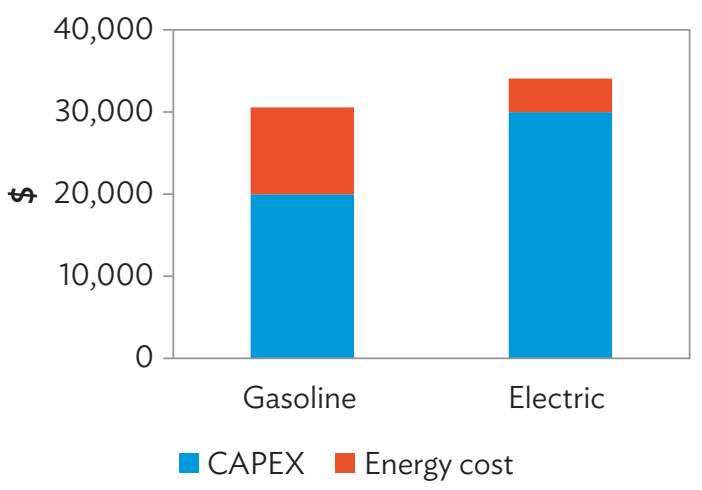

Urban Bus

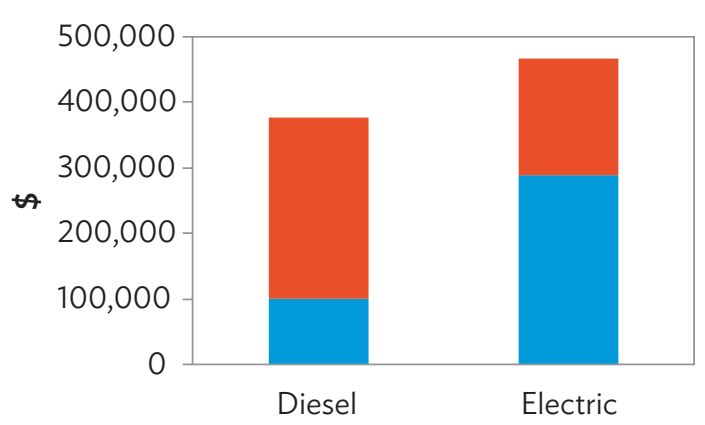

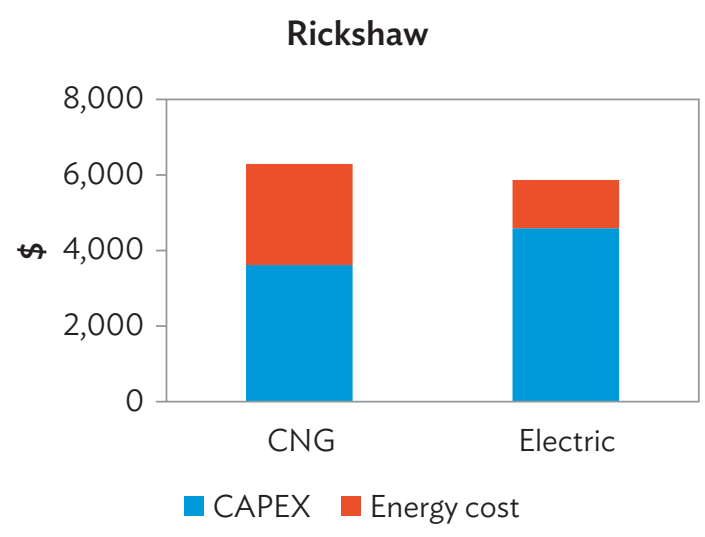

Taxi
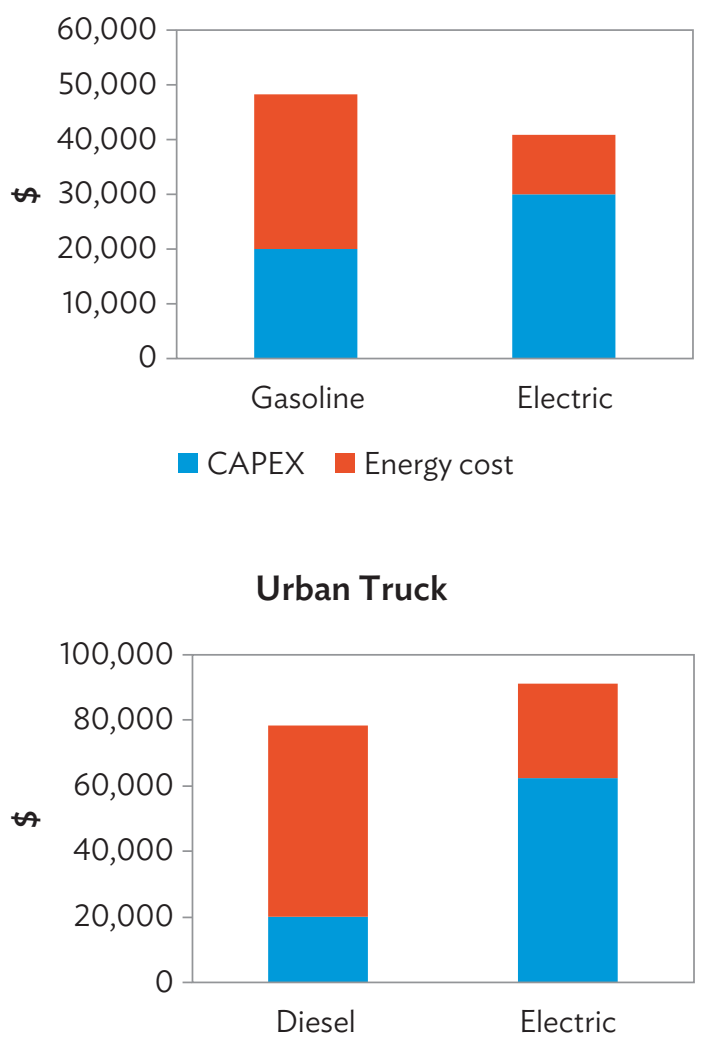

-CAPEX Energy cost

CAPEX = capital expenditure, $\mathrm{CNG}=$ compressed natural gas, $\mathrm{DMC}=$ developing member country, $\mathrm{kWh}=$ kilowatt-hour.

Source: All calculations by Grütter Consulting; non-discounted values; for data sets, see Appendix 1; based on average DMC fuel prices and an average electricity price of $0.16 \$ / \mathrm{kWh}$; CAPEX includes battery replacement during vehicle lifetime based on average battery life span with $50 \%$ of current battery prices. 
Table 8: Pollution Costs of ADB Developing Member Countries, 2014

$(\$ / t)$

\begin{tabular}{|c|c|}
\hline Pollution Cost Level & Countries \\
\hline $\begin{array}{l}\text { Low pollution costs }\left(\mathrm{SO}_{2}<\$ 630 / \mathrm{t} ; \mathrm{NO}_{x}<\$ 130 / \mathrm{t}\right. \\
\mathrm{PM}_{2.5}<\$ 18,000 / \mathrm{t}\end{array}$ & Afghanistan, Cambodia, Pakistan, Sri Lanka, Tajikistan \\
\hline $\begin{array}{l}\text { Moderate pollution costs: } \mathrm{SO}_{2} \text { from } \$ 630 / \mathrm{t} \text { to } \$ 3,000 / \mathrm{t} \text {; } \\
\mathrm{NO}_{\mathrm{x}} \$ 130 / \mathrm{t} \text { to } \$ 640 / \mathrm{t} ; \mathrm{PM}_{2.5} \text { from } \$ 18,000 / \mathrm{t} \text { to } \$ 80,000 / \mathrm{t}\end{array}$ & $\begin{array}{l}\text { Armenia, Bangladesh, Bhutan, Fiji, Georgia, India, Indonesia, } \\
\text { Kyrgyz Republic, Lao PDR, Mongolia, Myanmar, Nepal, } \\
\text { Philippines, Thailand, Turkmenistan, Uzbekistan, Viet Nam }\end{array}$ \\
\hline $\begin{array}{l}\text { High pollution costs : } \mathrm{SO}_{2}>\$ 3,000 / \mathrm{t} ; \mathrm{NO}_{x}>\$ 640 / \mathrm{t} ; \\
\mathrm{PM}_{2.5}>\$ 80,000 / \mathrm{t}\end{array}$ & Azerbaijan, Kazakhstan, Malaysia, PRC \\
\hline
\end{tabular}

$\mathrm{ADB}=$ Asian Development Bank, $\mathrm{DMC}=$ developing member country, Lao PDR $=$ Lao People's Democratic Republic, $\mathrm{NO}_{x}=$ nitrogen oxide, $\mathrm{PRC}=$ People's Republic of China, $\mathrm{PM}_{2.5}=$ particulate matter, $\mathrm{SO}_{2}=$ sulfur dioxide, $\mathrm{t}=$ ton.

Source: Grütter Consulting, based on upper and lower 20 percentile of pollution costs in DMCs of ADB, based on IMF. 2014. Getting Energy Prices Right. Washington, DC (\$ of 2010).

The median pollution cost in DMCs of $\mathrm{ADB}$ is $\$ 1,630$ per ton of sulfur dioxide $\left(\mathrm{SO}_{2}\right), \$ 340$ per ton of nitrogen oxide ( $\mathrm{NOx}$ ), and $\$ 46,000$ per ton of particulate matter $\left(\mathrm{PM}_{2.5}\right),{ }^{85}$ with huge ranges between countries. ${ }^{86}$ Table 8 groups countries based on low, moderate, and high pollution costs.

\subsection{Subsidies and Social Impact}

The primary justification of subsidizing EVs arises from their positive environmental impact. Results will vary between countries depending on the baseline vehicle fuel type, the emission standard, and the resulting pollution level of baseline vehicles and the grid factor influencing the GHG reduction.

The positive impact of EVs are basically reduced air pollution, reduced GHG, reduced noise levels, and reduced dependence on fossil fuels. The general public also enjoys the environmental benefits of improved air quality and reduced global warming. The poor are disproportionally affected by air pollution as they tend to be located closer to its sources. ${ }^{87}$ At the same time, the poor contribute less to the air pollution problem as they do not own private cars. Children and the elderly are particularly vulnerable. Recent studies also revealed that women are more affected by poor air quality than men. ${ }^{88}$

Incentives, including financial subsidies which foster the uptake of $\mathrm{EVs}$, can thus have positive economic as well as social benefits. However, financial subsidies require resources which can be obtained in a fiscally neutral manner, through increased fiscal revenues or through reduced spending in other government expenditures. The final social impact will depend largely on the source of revenue and what types of vehicles are subsidized (Table 9).

85 \$ of 2010 based on IMF. 2014. Getting Energy Prices Right. Washington, DC.

86 Range between lowest and highest value for $\mathrm{SO}_{2}$ : $190 \$ / \mathrm{t}$ to 4,400 $\$ /$ t; Range between lowest and highest value for $\mathrm{NO}_{x}: 40 \$ / \mathrm{t}$ and 3,500 \$/t; Range between lowest and highest value for $\mathrm{PM}_{2.5}: 6,000 \$ / \mathrm{t}$ and 124,000 \$/t.

87 Mitchell, G. and D. Dorling. 2003. An Environmental Justice Analysis of British Air Quality. Environment and Planning A. Vol. 35. 909-929.

88 Clougherty, J. 2010. A Growing Role for Gender Analysis in Air Pollution Epidemiology. Environmental Health Perspectives. February 2010. 118(2). 167-176 
Table 9: Potential Impact of Electric Vehicle Subsidy Schemes

\begin{tabular}{|c|c|c|}
\hline Subsidy Scheme & Social Impact & Comment \\
\hline $\begin{array}{l}\text { Subsidy of electric } \\
\text { public transport }\end{array}$ & $\begin{array}{l}\text { Users of public transport are, to a larger extent, the } \\
\text { poorer segment of society. Usage of public monies, } \\
\text { even if this implies expenditure, cuts in other areas } \\
\text { or increases in taxation levels, thus tends to have } \\
\text { a positive social impact as poorer segments profit } \\
\text { from reduced emissions as well as from subsidized } \\
\text { public transport. }\end{array}$ & $\begin{array}{l}\text { A larger positive social impact can be achieved } \\
\text { if EV subsidies are paid through reduced fuel } \\
\text { subsidies and/or through increased fossil fuel } \\
\text { taxation or increased taxation of private fossil } \\
\text { fuel vehicle owners. }\end{array}$ \\
\hline $\begin{array}{l}\text { Subsidy of } \\
\text { electricity prices } \\
\text { for EVs }\end{array}$ & $\begin{array}{l}\text { All EV vehicle categories profit, albeit private EV } \\
\text { owners tend to consume more electricity in total } \\
\text { and thus profit more. If the subsidy is financed } \\
\text { through general government revenues, then it can } \\
\text { have a slightly negative social impact depending on } \\
\text { the tax system. }\end{array}$ & $\begin{array}{l}\text { Subsidizing electricity prices for EVs can be } \\
\text { paid through higher electricity prices charged to } \\
\text { residential customers. This has the advantage } \\
\text { of not increasing costs for industries and } \\
\text { will also be socially more equitable as higher } \\
\text { income households have higher consumption } \\
\text { levels of electricity, and often prices of } \\
\text { electricity also increase after a certain base- } \\
\text { consumption level. Also, residential electricity } \\
\text { customers profit from the improved air quality. }\end{array}$ \\
\hline $\begin{array}{l}\text { Subsidy of private } \\
\text { EVs or taxis }\end{array}$ & $\begin{array}{l}\text { If subsidies paid are not fiscally neutral (e.g., tax } \\
\text { rebates which are not paid through higher taxes } \\
\text { on fossil fuel vehicles), then this subsidy scheme } \\
\text { will have a negative social impact as private vehicle } \\
\text { owners are the "wealthy" members of society } \\
\text { and expenditure cuts in other areas or increased } \\
\text { taxation levels will affect also the poor. }\end{array}$ & $\begin{array}{l}\text { Fiscally neutral policies, wherein financial } \\
\text { incentives are paid by fossil fuel vehicle owners } \\
\text { (e.g., through increased fossil fuel taxes and/ } \\
\text { or increased vehicle taxation levels) have a } \\
\text { positive environmental as well as social impact. }\end{array}$ \\
\hline
\end{tabular}

$\mathrm{EV}=$ electric vehicle.

Source: Grütter Consulting.

Many countries have subsidy systems in place which gradually decline or are active for a limited time. This is based on the (correct) assumption that prices of EVs decline over time, thus becoming also competitive without subsidies, and that more market players enter the field increasing the attractiveness of EVs as well as reducing their prices. Also, subsidies can reduce range constraints of buyers by establishing fast charging infrastructure. Once sufficient EVs are on the market, fast chargers can pay for themselves but are initially loss-making ventures. Therefore, subsidies are not needed forever-however, the magnitude and speed of reducing subsidies is difficult to preview and could thus be adjusted based on market circumstances in a gradual manner. Such policies are being followed by the PRC, for example.

\section{POLICIES}

\subsection{Overview Policies}

Policies are often grouped into price or financial incentives and nonprice measures. In countries with high electric vehicle (EV) uptake, both measures have been taken.

\section{Financial Incentives}

These are given to vehicles as well as charging infrastructure either as direct subsidies, fiscal incentives (tax benefits including purchase tax, value-added tax, annual circulation tax, registration tax, and others) 
or reduced energy costs with some countries charging lower electricity prices for EVs. ${ }^{89}$ Zero emission vehicle mandate programs such as those in California or the new EV policies in the PRC also result in financial incentives for EVs as car manufacturers need to comply with specific targets and offer EVs either at a competitive price or purchase surplus credits from other companies, thereby increasing the cost of fossil fuel cars and lowering the price of EVs. The PRC also used in some cities a reduction of car insurance as financial incentive. In some countries, subsidies are handed out for battery recycling.

Specific support for public charging infrastructure for passenger cars is considered essential as a positive sign for private companies to enter the market. But this is difficult to promote as long as the density of EVs is too small. Also, public charging stations in urban settings can be difficult to establish due to high investments, limited space, and limited options for demand management.

A number of cities give special incentives for fleet programs including taxis, car-sharing services, or car rentals, which have been successful in increasing the market share of EVs. ${ }^{90}$ Fleet operators send a demand signal to the market and act as amplifiers in promoting the uptake of EVs by their staff and customers. Government fleets and fleets controlled through public regulations such as service vehicles (including garbage trucks) and public transport buses are also good targets for e-fleet policies. The Government of Sweden, for example, mandates the adoption of environment-friendly and electric cars in government fleets. ${ }^{91}$

\section{Nonprice Incentives}

Nonprice incentives depend very much on the country and should be related to factors which influence purchase decisions of potential EV customers. These include:

- special lane access,

- parking perks,

- exemption from road and congestion charges,

- exemption from driving restrictions, and

- exemption from purchase restrictions.

Many of the nonprice as well as the financial incentives are of temporary nature until EVs have a certain market share. Norway, for example, in 2016 halted countrywide free parking for EVs due to the large number of such vehicles already being used. ${ }^{92}$

\section{Policy Impact}

Financial incentives are clearly central and important. In Norway, which has by far the highest EV market share worldwide, the retail price of an EV is at par with a conventional car, thanks to tax exemptions. ${ }^{93}$ In the PRC, which operates more than $95 \%$ of all e-buses worldwide, battery electric buses (BEBs) cost less to operate than diesel or gas buses of the same size due to producer subsidies from the national,

89 In some countries taxes, on transport fuels are used to finance transport infrastructure-with increasing shares of EVs, these taxes will either have to be levied on electricity used for transport or other forms of recovering transport infrastructure costs will have to be introduced (e.g., road tax).

90 ICCT. 2018c. Assessment of New Energy Passenger Vehicle Incentives in Cities in Chinese Cities.

91 IEA. 2018a. Nordic EV Outlook 2018. Paris..

92 IEA. 2017b. Global EV Outlook 2017. Paris.

93 IEA. 2018a. Nordic EV Outlook 2018. Paris. 


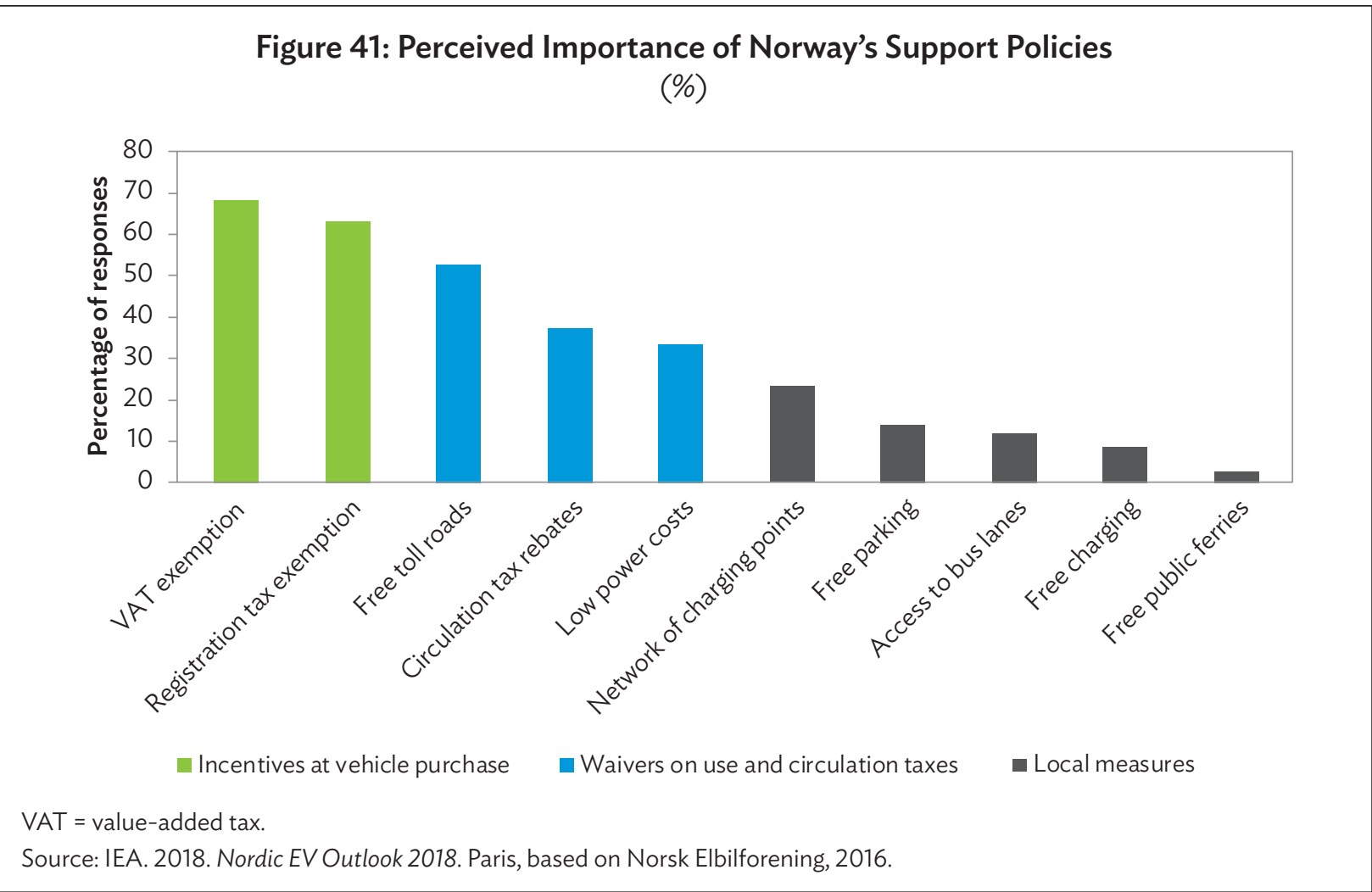

provincial, and local government. ${ }^{94}$ Figure 41 also shows that economic incentives are, at least in Norway, the main driver of EV uptake.

However, overall consumer benefits are the relevant criteria for uptake of EVs, shown also by different level of uptakes of EVs between cities in the PRC with different purchase subsidy levels (Figure 42), and by a comparison of financial incentives and EV market shares in different countries (Figure 43).

Without extensive incentives (financial and nonfinancial), uptake of EVs will be marginal (see, for example, for Europe, the correlation between the market uptake of EVs and customer incentives at http:// www.acea.be/statistics/article/interactive-map-electric-vehicle-incentives-per-country-in-europe).

National policies are basically targeted toward fiscal incentives. The biggest impact from fiscal incentives is achieved if the EV purchase premium is reduced. Nonfinancial incentives are basically developed at the municipal level and result in cities having a decisive influence in the adoption of EVs. Policies which have been especially successful in this context include waivers on regulations that limit the availability of license plates (e.g., used in many cities in the PRC), access to restricted urban areas, and exemptions from usage fees for road networks or parking fees. In Vancouver, building codes equire a certain share of wire conduits for accommodating chargers in multifamily homes. ${ }^{95}$ Such nonfinancial measures have

94 Grütter Consulting. 2018. Low Carbon Buses in PRC.

95 IEA. 2017b. Global EV Outlook 2017. Paris. 
Figure 42: Electric Vehicle Market Share and Purchase Subsidies-Electric Passenger Cars in Cities in the People's Republic of China

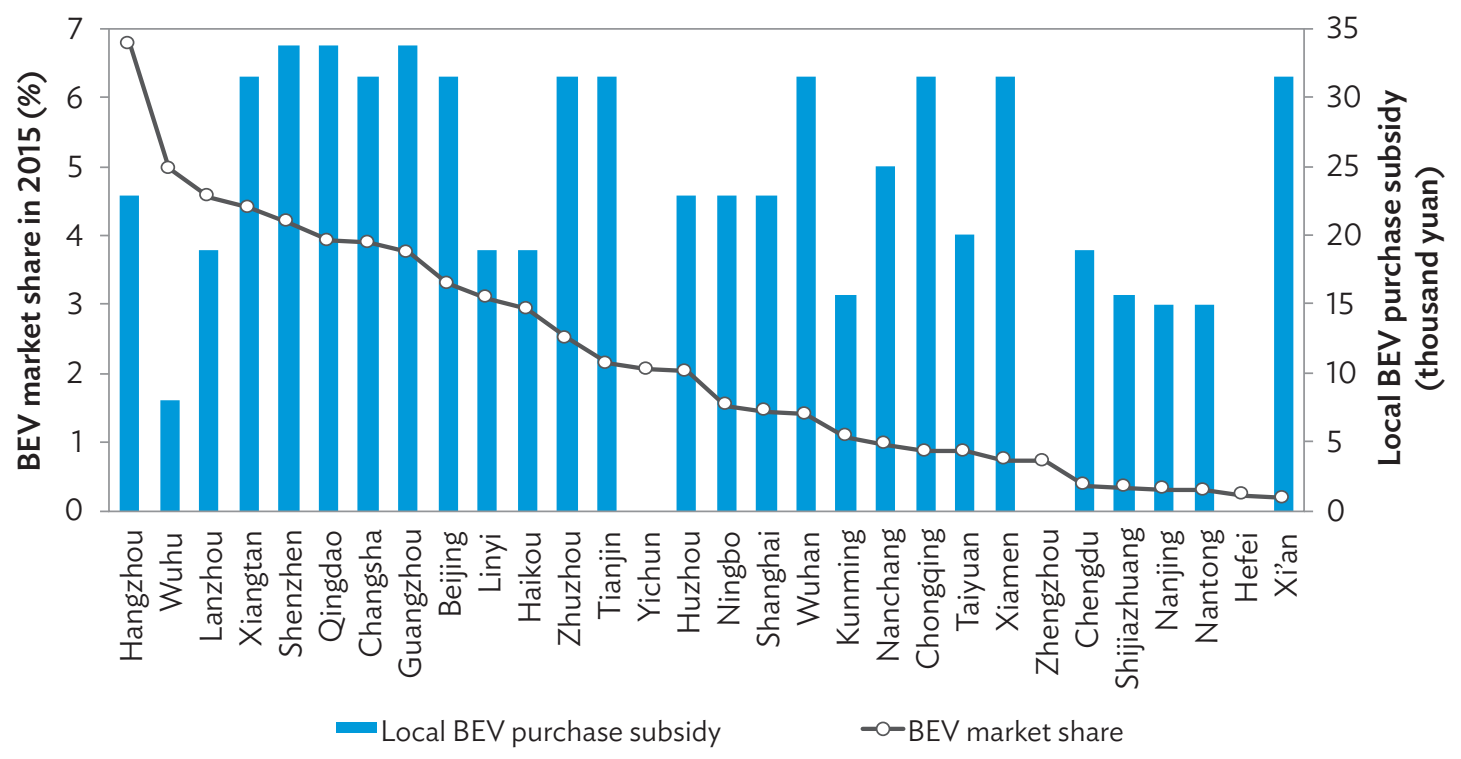

$\mathrm{BEV}=$ battery electric vehicle.

Source: ICCT. 2018. Assessment of New Energy Passenger Vehicle Incentives in Cities in Chinese Cities.

Figure 43: Fiscal Incentives and Electric Vehicle Market Uptake

$(\%)$

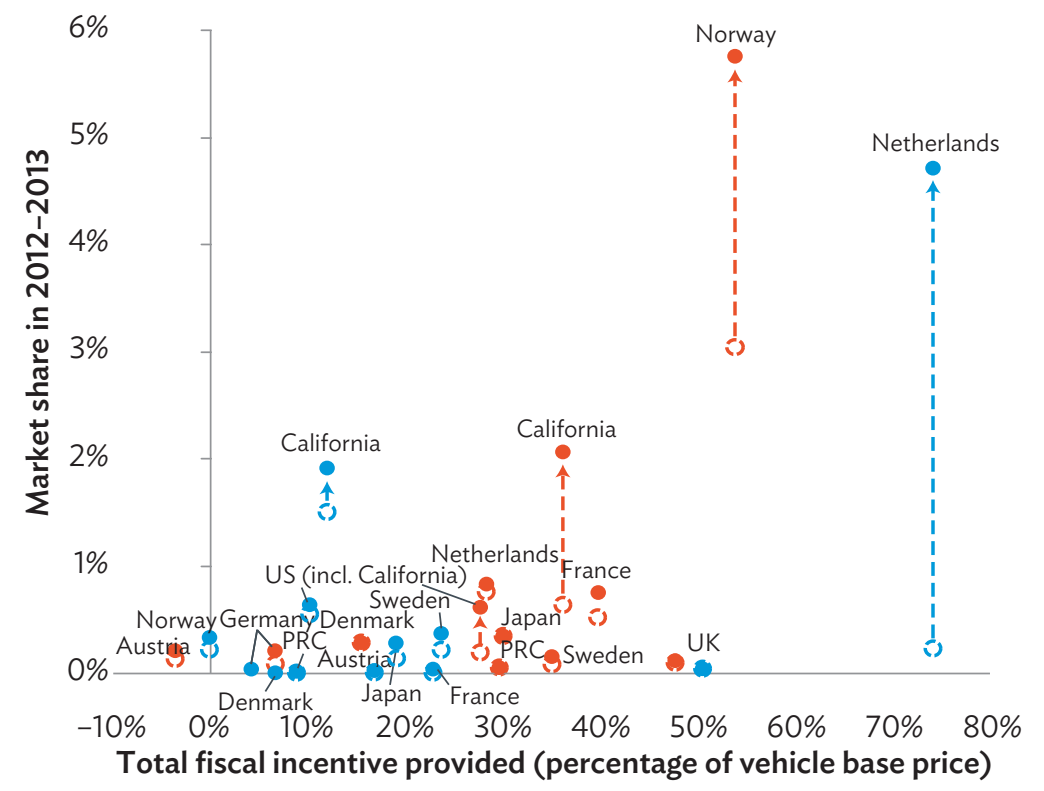

- BEV 2013 ¡BEV 2012 •PHEV 2013@PHEV 2012

$\mathrm{BEV}=$ battery electric vehicle, $\mathrm{PHEV}=$ plug-in hybrid electric vehicle, $\mathrm{PRC}=$ People's Republic of China, UK = United Kingdom, US = United States.

Source: ICCT. 2014. Driving Electrification: A Global Comparison of Fiscal Incentive Policy for Electric Vehicles. 
also a direct financial impact as they reduce either operating costs of EVs or increase their second-hand market price compared to conventional vehicles. Cities can, however, also offer financial incentives for vehicles (in addition to national and provincial incentives in many cities in the PRC) or for charging infrastructure.

A different financial structuring can also be potentially an important tool for EV promotion, including leasing. While up-front capital costs are higher for EVs, operation costs are lower. Spreading out the initial investment over the commercial life span of the EV makes the total annual costs similar to a conventional vehicle, due to lower energy and maintenance costs. This scheme is even more attractive if EVs are offered based on a fee per kilometer driven, including maintenance and energy (as provided for typically by car-sharing organizations). For customers, this makes EVs comparable in costs and risks to conventional vehicles. Leasing schemes (or detaching ownership of vehicles from their operations) are thus interesting business models or policies for promoting EVs.

An important long-term policy is also the potential ban of fossil fuel vehicles in the future. A number of countries, including India and the PRC, have proclaimed bans on fossil fuel vehicles, with the earliest being Norway by 2025 and many countries targeting by 2030 or by 2040 . A number of cities, including Paris, Rome, and Madrid, have also announced bans on diesel vehicles, although these bans do not cover gasoline vehicles or territorial boundaries where vehicles are banned might be small (e.g., in London the congestion charge zone has a very limited area).

\subsection{Electric Mobility Policies of Developing Member Countries}

Table 10 list the main policies of DMCs of ADB related to e-mobility.

\subsection{Potential Policies for Commercial Vehicles}

In most countries, policies have been directed toward private vehicles with limited attention being given to commercial vehicles, although the latter would have a far bigger impact with a lower price tag. Policies which could be deployed for different commercial vehicle categories to foster adoption of EVs include the following:

- Buses

- Require operators to have a certain share of EVs in their bus fleet, which gradually increases until reaching $100 \%$.

- Require new licensed routes to be operated by electric buses.

- Favor electric buses in public tendering of routes.

- Free charging infrastructure and/or reduced price for electricity as compensation for improved air quality and reduced noise (public goods).

- Up-front purchase subsidies.

- Limit access to city center to electric buses;

- Support the creation of entities which purchase large fleets of electric buses and lease them to operators.

- Require all buses to be electric by a certain date.

- Increase the diesel tax. 
Table 10: E-Mobility Policies of ADB Developing Member Countries, as of July 2018

\begin{tabular}{|c|c|}
\hline Country & Policies \\
\hline Afghanistan & $\begin{array}{l}\text { No EV policy or incentives for EVs. The NDC mentions clean and alternative fuels but not specifically EVs. The } \\
\text { National Communications mentions trolleybuses as mitigation means. }\end{array}$ \\
\hline Armenia & $\begin{array}{l}\text { The NDC specifically mentions electric transportation as main contributor toward GHG mitigation in the transport } \\
\text { sector. The Yerevan Master Plan for } 2006-2020 \text { plans to increase the passenger share of trolleybuses from } 3 \% \text { to } \\
24 \% \text {. Tax incentives have been established with zero import taxes for EVs (conventional vehicles pay including value- } \\
\text { added tax up to 32\%). }\end{array}$ \\
\hline Azerbaijan & $\begin{array}{l}\text { The NDC has as mitigation areas the usage of EVs for public transportation (however, with a focus on rail-based } \\
\text { transport). Apart from this no EV policies or incentives. }\end{array}$ \\
\hline Bangladesh & No policies or incentives for EVs (electrification of rail transport is a target). \\
\hline Bhutan & $\begin{array}{l}\text { Bhutan promotes EVs with tax incentives. EVs are exempt from sales tax, customs duty, and green tax, which total } \\
100 \%-180 \% \text { of the car value depending on the engine displacement. However, India-made vehicles (representing } \\
\text { the huge majority of vehicles) are exempt from the } 50 \% \text { customs duty. The country has an EV initiative including } \\
\text { a GEF project for electric taxis. It has also discussed an EV road map for commercial vehicles (buses, urban trucks, } \\
\text { and taxis). }\end{array}$ \\
\hline Cambodia & $\begin{array}{l}\text { The NDC has as mitigation areas the promotion of EVs with specific mention of electric scooters. Apart from this, no } \\
\text { implemented EV policies or targets. }\end{array}$ \\
\hline Cook Islands & No policies or targets in place for promotion of EVs. \\
\hline Fiji & $\begin{array}{l}\text { The NDC indicates a need for promoting EVs; } 0 \% \text { import tax for hybrid taxis (however, new fossil fuel taxis also only } \\
\text { pay 5\%); ambitious EV targets are under discussion for the NDC implementation plan to } 2030 \text {. }\end{array}$ \\
\hline Georgia & $\begin{array}{l}\text { Imports of electric cars are tax free; ' however, import and excise taxes on conventional vehicles are very low, thus not } \\
\text { resulting in an effective promotion of EVs. }\end{array}$ \\
\hline India & $\begin{array}{l}\text { India has a National Electric Mobility Mission Plan to } 2020 \text { and a Faster Adoption and Manufacturing of Hybrid and } \\
\text { Electric Vehicle scheme in place. Significant financial incentives (especially for buses and comparative to price for } \\
\text { motorcycles and 3-wheelers) are given under this program, but it lacks clarity, long-term planning, and predictability. } \\
\text { In 2-wheelers, subsidies for vehicles using lead-acid batteries will be removed to encourage usage of lithium-ion } \\
\text { units. The strategy is to initially penetrate the EV market in public transport (taxis, buses, rickshaws) and with fleet } \\
\text { operators. However, no comprehensive EV policy is yet in place and the government seemingly wants to present an } \\
\text { action plan for EV mobility and not an EV policy itself. By } 2030,30 \% \text { of all vehicles will be electric.g Taking the lead } \\
\text { when it comes to rolling out policies for the promotion of EVs are individual states including Karnataka, Telangana, } \\
\text { Maharashtra, Andhra Pradesh, Goa, and Uttar Pradesh, which have instituted guidelines and policies for adoption } \\
\text { of EVs. }\end{array}$ \\
\hline Indonesia & $\begin{array}{l}\text { The government has set a target of } 20 \% \text { of new vehicles sold by } 2025 \text { to be hybrid or electric. }{ }^{\text {h }} \text { An EV road map is } \\
\text { under discussion, but no incentives have yet been implemented. }\end{array}$ \\
\hline Kazakhstan & No policies or incentives for EVs. \\
\hline Kiribati & No policies or incentives for EVs. \\
\hline Kyrgyz Republic & No policies or incentives for EVs. \\
\hline Lao PDR & No policies or incentives for EVs. A draft strategic plan for EVs is under preparation.' \\
\hline Malaysia & $\begin{array}{l}\text { Malaysia intends to position itself as electric mobility marketplace in the region by } 2030 . \text { In } 2015 \text {, Malaysia set targets } \\
\text { of } 100,000 \text { electric cars, } 100,000 \text { electric motorcycles, } 2,000 \text { electric buses, and 125,000 charging stations by } 2020 \text {. } \\
\text { Target achievement by } 2018 \text { is } 1 \% \text { or less. The target has been moved to } 2030 .{ }^{k} \text { Tax breaks on imported EVs have } \\
\text { been stopped in } 2017 !\end{array}$ \\
\hline Maldives & No policies or incentives for EVs. \\
\hline Marshall Islands & The NDC has as target the introduction of EVs, but no policies or incentives in place. \\
\hline Micronesia & No policies or incentives for EVs. \\
\hline Mongolia & $\begin{array}{l}\text { EVs are exempted from driving restrictions (even-odd license plate system) in Ulaanbaatar and from road user } \\
\text { charges. }\end{array}$ \\
\hline Myanmar & No policies or incentives for EVs. \\
\hline Nauru & No policies or incentives for EVs. \\
\hline Nepal & $\begin{array}{l}\text { The environment-friendly Vehicle and Transport Policy aims, among other things, to increase the share of EVs to } 20 \% \\
\text { by } 2020 \text {, and to provide for a subsidy scheme for the promotion of electric and non-motorized vehicles. Reduced } \\
\text { customs duties on private and public EVs. EVs do not pay the annual vehicle tax." }\end{array}$ \\
\hline Pakistan & No customs duty for EVs. ${ }^{n}$ \\
\hline Palau & No policies or incentives for EVs. \\
\hline Papua New Guinea & No policies or incentives for EVs. \\
\hline PRC & $\begin{array}{l}\text { "New energy vehicles" (used in the PRC as term for EVs including hybrids) have been promoted by the PRC since } \\
2009 \text { at different levels. The NDC mentions the promotion of new energy vehicles to control emissions from the } \\
\text { transportation sector. Massive up-front subsidies and fiscal incentives for all types of EVs from national, provincial, } \\
\text { and local governments have been put in place, and many cities offer a wide array of nonfinancial incentives. }{ }^{2} \text { The PRC } \\
\text { has established a recycling policy of batteries for EVs and has announced to ban fossil fuel vehicles (no target date } \\
\text { has yet been set). }\end{array}$ \\
\hline
\end{tabular}


Table 10 continued

\begin{tabular}{ll}
\hline Country & \multicolumn{1}{c}{ Policies } \\
\hline Philippines & $\begin{array}{l}\text { No excise tax for EVs. Some nonfinancial incentives by local government such as preferential franchise and/or route } \\
\text { for e-trikes, exemption from number coding scheme, and longer franchise years. }\end{array}$ \\
Samoa & No policies or incentives for EVs. \\
Solomon Islands & No policies or incentives for EVs. \\
Sri Lanka & The NDC mentions as mitigation strategy EVs especially 3-wheelers, buses, and cars (as well as ships and railway). \\
& Reduced tax for import of new EVs. Plans to set up charging stations by government. $A$ A NAM on an electric BRT \\
& was developed by UNDP which the government, however, did not submit for registration at the UNFCCC. \\
Tajikistan & No policies or incentives for EVs. \\
Thailand & Vehicle excise tax for domestic produced EVs is at 2\%-10\% while for conventional vehicles is 10\%-30\%; tax breaks \\
& for charging stations. Government offices shall devote 20\% of their budget to buy EVs and the Bangkok Mass Transit \\
Timor-Leste & Authority must buy 200 BEBs. Thailand is specifically promoting the production of EVs with import exemptions for \\
Tonga & equipment and tax breaks. ${ }^{9}$ \\
Turkmenistan & No policies or incentives for EVs. \\
Tuvalu & No policies or incentives for EVs. \\
Uzbekistan & No policies or incentives for EVs. \\
Vanuatu & No policies or incentives for EVs. \\
Viet Nam & No policies or incentives for EVs. \\
& A low-carbon bus NAMA has been registered by Viet Nam at the UNFCCC, which targets 10\% new acquired \\
& vehicles by 2030 as electric buses. No policies and incentives yet in place for EVs.
\end{tabular}

$\mathrm{BEB}=$ battery electric bus, $\mathrm{BRT}=$ bus rapid transit, $\mathrm{EV}=$ electric vehicle, $\mathrm{GEF}=$ Global Environment Facility, GHG = greenhouse gas, Lao PDR = Lao People's Democratic Republic, NAMA = nationally appropriate mitigation action, NDC = nationally determined contribution, PRC = People's Republic of China, UNDP = United Nations Development Programme, UNFCCC = United Nations Framework Convention on Climate Change.

a For cars: ICCT. 2018c. Assessment of New Energy Passenger Vehicle Incentives in Cities in Chinese Cities/ICCT. 2018d. PR China's New Energy Vehicle Mandate Policy (Final Rule); for buses: Grütter Consulting. 2018. Low Carbon Buses in PRC; for motorcycles: Yang, C. J. 2010. Launching Strategy for Electric Vehicles. Technological Forecasting and Social Change 77. 831-834.

b Research and Library Services, Parliament of the Republic of Fiji. Customs Tariff (Budget Amendment) Bill 2017. http://www. parliament.gov.fj/wp-content/uploads/2017/03/Bill-Summary-Bill-32-2017-Customs-Tariff-Amendment-FINAL.pdf.

c Tabula. 2016. Global Petrol Prices. 25 November. http://www.tabula.ge/en/story/114966-100-electric-vehicle-charging-points-toopen-in-georgia.

d McKinsey. 2017c. The Future of Mobility in India: Challenges \& Opportunities for the Auto Component Industry; Innovation Norway. 2017. India EV Story; FAME-India (National Mission on Electric Mobility). https://www.fame-india.gov.in/.

e To be developed by NITI Aayog (National Institution for Transforming India).

f M. Ghosh. 2018. Now an 'action plan' in place of policy for electric vehicles. Livemint. 12 March. https://www.livemint.com/Industry/ tICseS1IEHCW6aMqu5hU4O/Now-an-action-plan-in-place-of-policy-for-electric-vehicle.html.

$g$ The original target announced was 100\%; see Firstpost. 2018. India has Shifted it's (sic) Target of Electric Mobility from 100 percent to 30 percent by 2030: Report. 10 March. https://www.firstpost.com/tech/news-analysis/india-has-shifted-its-target-of-electricmobility-from-100-percent-to-30-percent-by-2030-report-4383405.html.

h Jakarta Globe. 2018. Gov't to Slash Taxes on Electric Cars. 26 February. https://jakartaglobe.id/context/govt-slash-taxes-electriccars.

i E. Phouthonesy. 2018. Govt to tackle trade deficit by promoting electric vehicles. Asia News Network. 31 March. http://annx.asianews. network/content/govt-tackle-trade-deficit-promoting-electric-vehicles-73903.

i Gee. 2015.

k M.F. Shah. 2017. More electric powered vehicles by 2030 to reduce gas emissions. The Star Online. 19 August. https://www.thestar. com.my/metro/community/2017/08/19/more-electric-powered-vehicles-by-2030-to-reduce-gas-emissions/.

I The Malaysian Reserve. 2017. Govt ends tax breaks for hybrids and EEVs. 31 March. https://themalaysianreserve.com/2017/03/31/ govt-ends-tax-breaks-for-hybrids-and-eevs/.

m P. Shahi. 2017. Electric Vehicles in Nepal: What You Need To Know. Onward Nepal. 5 June. http://www.onwardnepal.com/nepal/ electric-vehicles-nepal/.

n B. Hussain. 2018. Customs duty on import of electric cars cut to 25\%. The Express Tribune. 28 April. https://tribune.com.pk/ story/1697321/2-customs-duty-import-electric-cars-cut-25/.

- A. Garcia. 2017. Alternative Fuels Vehicle and Technology. https://www.doe.gov.ph/sites/default/files/pdf/announcements/ epower_05_02_alternative_fuels_vehicle_technology.pdf.

p The Sunday Times. 2017. Sri Lanka plans to phase out the gas-powered vehicles. 10 December. http://www.sundaytimes.lk/171210/ business-times/sri-lanka-plans-to-phase-out-the-gas-powered-vehicles-271929.html.

a Yongpisanphob, W. 2017. Thailand and the Development of Electric Vehicles.

Sources: Based on latest National Communications, Biennial Update Reports, and Nationally Determined Contributions. 
- Urban trucks

- Require operators to have a certain share of EVs in their truck fleet, which gradually increases until reaching $100 \%$.

- Support the establishment of public fast chargers also powerful enough for urban trucks and at locations apt for urban trucks.

- Introduce electric urban trucks for publicly operated or financed services such as waste collection.

- Free charging infrastructure and/or reduced price for electricity as compensation for improved air quality and reduced noise (public goods).

- Up-front purchase subsidies.

- Limit access to city center to electric trucks;

- Preferred access to urban areas for electric trucks (e.g., earlier in the morning).

- Support the creation of entities which purchase large fleets of electric trucks and lease them to operators.

- Require all trucks, which shall be operated in urban areas, to be electric by a certain date.

- Increase the diesel tax and/or introduce a road vehicle tax levied only on fossil fuel vehicles.

- Reduce or eliminate taxes on electric trucks.

- Taxis, car-sharing organizations, shared mobility

- Support the establishment of public fast chargers at multiple locations.

- Free charging infrastructure and/or reduced price for electricity as compensation for improved air quality and reduced noise (public goods).

- Up-front purchase subsidies.

- Preferential access to new licenses or limit new vehicles to electric units.

- Limit access to city center to EVs.

- Support car-sharing organizations which go pure electric.

- Ban fossil fuel vehicles in the city from a certain date.

- Increase the diesel and gasoline tax.

o Reduce or eliminate taxes on EVs.

\section{PRELIMINARY ASSESSMENT OF ELECTRIC VEHICLES' POTENTIAL IN ADB DEVELOPING MEMBER COUNTRIES AND RECOMMENDED SUPPORT POLICIES}

\subsection{Electric Vehicle Potential of Developing Member Countries}

This chapter summarizes the potential of electric vehicle (EV) uptake and the impact EVs would have on developing member countries (DMCs) of ADB based on existing market proliferation of EVs in the country, environmental criteria (greenhouse gas [GHG] and local pollution impact), financial conditions, and policies in place. Table 11 shows criteria, parameters, and benchmarks used. 
Table 11: Assessment Criteria, Parameters, and Benchmarks

\begin{tabular}{|c|c|c|c|}
\hline Criteria & Relevance & Parameter & Benchmark \\
\hline $\begin{array}{l}\text { Market } \\
\text { proliferation }\end{array}$ & $\begin{array}{l}\text { A significant market share of } \\
\text { EVs means that a good public } \\
\text { charging infrastructure is in } \\
\text { place and awareness of EVs is } \\
\text { high, resulting in faster market } \\
\text { adoption. }\end{array}$ & $\begin{array}{l}\text { Number of EVs } \\
\text { in the country }\end{array}$ & $\begin{array}{l}\text { - Low: less than } 1,000 \mathrm{EV} \text { s excluding trolleybuses } \\
\text { - Moderate: less than } 0.5 \% \text { market share or limited } \\
\text { to } 2 \text { - and/or 3-wheelers } \\
\text { - High: more than } 0.5 \% \text { market share and at least } \\
\text { three subcategories of vehicles with more than } \\
1,000 \text { units (buses, trucks, cars, motorcycles, } \\
\text { 3-wheelers) }\end{array}$ \\
\hline GHG Impact & $\begin{array}{l}\text { The potential GHG reduction } \\
\text { impact of EVs per replaced fossil } \\
\text { fuel vehicle. }\end{array}$ & $\begin{array}{l}\text { Carbon factor } \\
\text { of electricity }\end{array}$ & $\begin{array}{l}\text { - Low: grid factor more than } 0.8 \mathrm{kgCO}_{2} \mathrm{e} / \mathrm{kWh} \\
\text { - Moderate: grid factor between } \\
0.35-0.8 \mathrm{kgCO}_{2} \mathrm{e} / \mathrm{kWh} \\
\text { - High: grid factor below } 0.35 \mathrm{kgCO}_{2} \mathrm{e} / \mathrm{kWh}\end{array}$ \\
\hline $\begin{array}{l}\text { Local pollution } \\
\text { impact }\end{array}$ & $\begin{array}{l}\text { A high impact on pollution can } \\
\text { be expected in countries with } \\
\text { low vehicle emission standards. } \\
\text { The relevance of the pollution } \\
\text { impact is expressed through the } \\
\text { economic costs of pollutants. }\end{array}$ & $\begin{array}{l}\text { Emission } \\
\text { standard of } \\
\text { vehicles } \\
\text { Economic cost } \\
\text { of pollution }\end{array}$ & $\begin{array}{l}\text { - For emission standard: } \\
\text { - Low: Euro } 4 \text { or Euro } 5 \\
\text { - Moderate: Euro } 2 \text { or Euro } 3 \\
\text { - High: no emission standard } \\
\text { - For economic cost: } \\
\text { - Low: pollution costs in the lower } 20 \text { percentile of } \\
\text { DMCs } \\
\text { - Moderate: pollution costs between the lower and } \\
\text { upper } 20 \text { percentile of DMCs } \\
\text { - High: pollution costs in the upper } 20 \text { percentile of } \\
\text { DMCs }\end{array}$ \\
\hline $\begin{array}{l}\text { Financial } \\
\text { condition for } \\
\text { EVs }\end{array}$ & $\begin{array}{l}\text { One of the most important } \\
\text { market conditions for the } \\
\text { adoption of EVs is fossil fuel } \\
\text { price as this is the major } \\
\text { parameter influencing relative } \\
\text { operational costs between EVs } \\
\text { and conventional vehicles. }\end{array}$ & $\begin{array}{l}\text { Diesel and } \\
\text { gasoline price }\end{array}$ & $\begin{array}{l}\text { Low: fuel prices in the lower } 20 \text { percentile of } \\
\text { DMCs } \\
\text { - Moderate: fuel prices between the lower and } \\
\text { upper } 20 \text { percentile of DMCs } \\
\text { - High: fuel prices in the upper } 20 \text { percentile of } \\
\text { DMCs }\end{array}$ \\
\hline Policies & $\begin{array}{l}\text { EV policies and incentives in } \\
\text { place are core factors for uptake } \\
\text { of EVs. }\end{array}$ & $\begin{array}{l}\text { Policies and } \\
\text { incentives in } \\
\text { place. }\end{array}$ & $\begin{array}{l}\text { - Low: no policies in place } \\
\text { - Moderate: initial to moderate policies in place } \\
\text { - High: moderate to strong policies in place }\end{array}$ \\
\hline
\end{tabular}

$\mathrm{DMC}=$ developing member country, $\mathrm{EV}=$ electric vehicle, $\mathrm{kgCO}_{2} \mathrm{e} / \mathrm{kWh}=$ kilogram of carbon dioxide equivalent emission per kilowatt-hour.

a The borders are determined based on the upper and lower 20 percentile of the all grid factors in DMCs of ADB.

Source: Grütter Consulting.

The cumulative result shows the gross potential of countries for EV promotion based on a cumulative, non-weighted summary of the above criteria, assigning 1 point for every low mark, 2 points for every moderate mark, and 3 points for every high mark. Low potential is given for countries with 5-7 points, moderate potential for countries with 8-12 points, and high potential for countries with 12-15 points. Considering all criteria, Nepal and the People's Republic of China (PRC) have the highest EV potential while those with low potential include Azerbaijan, Kazakhstan, Turkmenistan, and Uzbekistan. However, EVs are basically promoted to improve the environment. The following map therefore just combines the environmental criteria to identify countries where EVs would have a significant environmental impact and countries where EVs will only have a marginal environmental impact. 
Table 12: Environmental Potential of Electric Vehicles in ADB Developing Member Countries

\begin{tabular}{ll}
\hline EV Potential & \multicolumn{1}{c}{ Country } \\
\hline Low environmental impact & India \\
Low to moderate environmental impact & $\begin{array}{l}\text { Indonesia, Kazakhstan, Mongolia, Pakistan, Philippines, Sri Lanka, Thailand, } \\
\text { Viet Nam }\end{array}$ \\
Moderate environmental impact & Afghanistan, Armenia, Azerbaijan, Bangladesh, Bhutan, Cambodia, \\
& Kyrgyz Republic, Malaysia, PRC, Turkmenistan, Uzbekistan \\
Moderate to high environmental impact & Myanmar, Nepal \\
High environmental impact & Georgia, Lao PDR, Tajikistan \\
\hline
\end{tabular}

EV = electric vehicle, GHG = greenhouse gas, Lao PDR = Lao People's Democratic Republic, PRC = People's Republic of China.

Note: Based on cumulative impact on GHG reduction potential (measured with the carbon grid factor) ${ }^{96}$ and the local pollution impact measured by the combination of the current emission standard for fossil vehicles ${ }^{97}$ and the cost of environmental pollution (for sulfur dioxide, nitrogen oxide, and particulate matter). ${ }^{98}$

Source: Grütter Consulting.

Particularly interesting countries to promote EVs, considering only environmental aspects, are therefore the Lao PDR, Georgia, and Tajikistan, while Myanmar and Nepal are also of high interest. The lowest environmental impact is experienced in India, where a greening of the grid is imperative, while the local pollution impact is limited due to the recent introduction of stringent vehicle emission standards.

\subsection{Recommended Electric Vehicle Support Policies for ADB}

Support for EVs needs to be country- or city-specific. However, some general recommendations are given concerning EV policies for ADB:

1. The greener and less carbon-free the electricity grid, the larger the impact of EVs. EV support measures thus clearly make more sense in countries which predominantly have a renewable energy grid. In countries with a grid factor of electricity production of more than 0.8 kilogram of carbon dioxide equivalent emission per kilowatt-hour $\left(\mathrm{kgCO}_{2} \mathrm{e} / \mathrm{kWh}\right)$, fostering EVs will result in only a very minor GHG impact. In such countries, ADB policies could rather be directed toward greening the grid and not toward aggressively promoting $\mathrm{EV}$ s.

2. Countries with a predominantly renewable energy production combined with air pollution problems are ideal candidates for promoting EVs. They can achieve a large GHG impact, improving local air quality and reducing dependency on fossil fuels. EV support from ADB should thus focus on such countries.

3. The largest impact concerning GHG reduction and air quality improvement can be achieved with commercial vehicles. Also, the cost-benefit ratio of commercial EVs tends to be far better than of private vehicles due to high mileage and energy usage. This includes basically buses, taxis/ ride-sharing vehicles, and urban trucks. ADB support policies toward EVs should thus be geared on these vehicle segments. ADB transport programs, especially if conducted within countries with favorable circumstances (see previous recommendation) should include components on e-mobility, including charging infrastructure.

96 High grid factor results in low GHG reduction potential of EVs and vice versa.

97 The more stringent the vehicle emission standard the less impact EVs have and vice versa.

98 The higher the cost of pollutants the larger the impact of EVs and vice versa. 
4. Cities play an important role in the adoption of EVs as they experience air pollution and noise pollution problems - which can be alleviated by EVs - and also have a large concentration of commercial vehicles. Many cities are also concerned about their $\mathrm{CO}_{2}$ footprint. Urban development programs, especially urban transport programs, offer ideal entry points to include EV support policies and programs.

5. EV policies can include subsidies but should be as fiscally neutral and socially positive as possible. This needs to be included when designing EV support policies by ADB.

\section{SELECTED ELECTRIC VEHICLE IMPLEMENTATION CASES IN ASIA}

\subsection{Introduction}

In the following selected electric vehicle (EV) implementation, cases are briefly assessed. The cases selected are based on projects already implemented, some since various years, thus allowing also to analyze success factors as well as critical points. The cases are based on different business models and different vehicle categories and have potentially a good replication potential in developing member countries (DMCs) of ADB.

All cases have the following structure:

- Short description of the country settings concerning EV deployment.

- Policy or business model.

- Impact.

- Success factors and critical aspects.

\subsection{E-Buses in the People's Republic of China}

\subsubsection{Country Circumstances}

In 2017, there were around 385,000 e-buses ${ }^{99}$ operating globally, with $99 \%$ of all e-buses operating in the People's Republic of China (PRC). ${ }^{100}$ Electric and plug-in hybrid buses made up $17 \%$ of the total bus fleet and 22\% of total bus sales in the PRC in 2017. The PRC also has the world's largest electric bus fleet in Shenzhen city with more than 16,000 units, with all buses in Shenzhen being electric since end-2017. The PRC has therefore a unique experience with the operation of e-buses-their performance, their impact, as well as challenges. ${ }^{101}$

Most cities in the PRC use natural gas buses, complying with the national emission standard CN IV or $\mathrm{CN} V$, which are largely equivalent to the same category European Union standards. The large majority of hybrid buses used in cities are standard 10-12-meter $(\mathrm{m})$ buses while $60 \%$ of battery electric buses (BEBs) are 6-8-m units, with the largest BEBs operated commercially being very few 18-m articulated units (as trolleybuses and with opportunity charging) and 14-m double-deckers. BEBs are mostly used on shorter routes with less passenger demand compared with conventional buses. As of 2018, cities in the PRC typically operate a share of $40 \%$ of low-carbon buses (LCBs), including hybrids, plug-in hybrids,

\footnotetext{
99 Includes pure electric buses and plug-in hybrids.

100 Bloomberg New Energy Finance. 2018. Electric Buses in Cities.

101 Based largely on Grütter Consulting. 2018. Low Carbon Buses in PRC.
} 
fuel cell buses, and electric units, of which around half are pure e-buses. Many cities stopped purchasing conventional fossil fuel buses and target a 100\% LCB fleet within the next few years.

\subsubsection{Core Characteristics of Electric Vehicle Buses Deployed in the People's Republic of China}

Since 2009, LCBs have been promoted by the PRC at different levels, by national, provincial, and city authorities. Basically, up-front purchase subsidies are given which result in LCBs being cheaper to purchase than same size diesel or gas buses. These huge subsidies have resulted in a large uptake of hybrid and electric buses in the PRC. It has allowed for the breakthrough of the technology and has effectively eliminated the barrier toward adoption of LCBs by bus operators. Subsidies are gradually phased out (e.g., hybrids are no longer subsidized), with the target of fully phasing out subsidies by 2021. Subsidies are related to the bus length, electric driving range, efficiency, and technology used (e.g., opportunity charge or fast charge). However, subsidies are not technology- and size-neutral and favor smaller buses with an intermediate battery pack.

A series of interim rules put forward in February 2018 hold EV manufacturers responsible for the recovery of $\mathrm{EV}$ batteries. They are required to set up recycling channels and service outlets where old batteries can be collected, stored, and transferred to specialist recyclers. Together with battery makers and their sales units, EV manufacturers must also set up a "traceability" system to enable the identification of owners of discarded batteries. Battery makers are also encouraged to adopt standardized and easily dismantled product designs, to help automate the recycling process. They must also provide technical training for vehicle makers on how to store and dismantle old batteries.

Plug-in hybrid buses are very popular in the PRC due to the phase-out of subsidies for standard hybrids. However, operators in do not charge their plug-in hybrids and use them in the same manner as standard hybrids, with the same environmental and financial impact as the latter and without the $20 \%$ subsidy. Plug-in hybrid buses are not charged at the grid because of they are equipped with a small battery and overall due to the operational complexity of charging the buses.

Multiple types of electric buses are available in the PRC including BEBs charged only overnight, BEBs charged overnight and fast charged during the day, opportunity charged electric buses with charging at the end of routes or at stops on the route, as well as electric trolleybuses which can operate also without overhead wiring. Battery packs used in BEBs are, on average, $210 \mathrm{kWh}$ for $10-12-\mathrm{m}$ buses and $120 \mathrm{kWh}$ for 8-m buses. The approach used toward charging of BEBs is basically overnight charging plus one or multiple fast charges of 15-30 minutes during the day using high powered chargers of 150-400 kW. Battery-swap facilities have been abandoned due to very high costs and the availability of high-powered chargers at a relatively low cost, combined with the ability of bus batteries to take on fast charging at high power levels. Opportunity charge systems have only been installed in a few cities and on selected routes. Electric trolleybuses with an autonomy range of 30-50 km without overhead wiring are used in some cities especially on bus rapid transit routes. Batteries are guaranteed by most manufacturers for 8 years with $80 \%$ state of charge (SOC). Buses in the PRC are often replaced after 8 years, i.e., battery replacement coincides with bus renewal. Table 13 summarizes the pros and cons of different charging technologies. 
Table 13: Charging Systems and Battery Packs

\begin{tabular}{|c|c|c|}
\hline Charging System & Advantages & Disadvantages \\
\hline $\begin{array}{l}\text { Overhead wiring } \\
\text { (trolleybus) }\end{array}$ & $\begin{array}{l}\text { Minimum battery amount on vehicle thus } \\
\text { reducing vehicle weight, space required for } \\
\text { batteries, and vehicle cost. Simple battery } \\
\text { management system. }\end{array}$ & $\begin{array}{l}\text { High infrastructure cost and limited route flexibility, } \\
\text { electricity cost can be higher due to peak and } \\
\text { off-peak day electricity consumption, high power } \\
\text { requirements on the electric grid, and high demand } \\
\text { charge }^{\text {a }}\end{array}$ \\
\hline $\begin{array}{l}\text { Opportunity } \\
\text { charging including } \\
\text { ultra-fast charging }\end{array}$ & $\begin{array}{l}\text { Small to minimum battery amount on vehicle } \\
\text { thus reducing vehicle weight, space required } \\
\text { for batteries, and vehicle cost. }\end{array}$ & $\begin{array}{l}\text { High infrastructure cost and limited route flexibility; } \\
\text { electricity cost can be higher due to peak and } \\
\text { off-peak day electricity consumption; high power } \\
\text { requirements on the electric grid, and high demand } \\
\text { charge, but this can eventually be avoided with peak } \\
\text { shaving }\end{array}$ \\
\hline Fast charging & $\begin{array}{l}\text { Increased vehicle range with lower battery } \\
\text { quantity thus reducing vehicle weight and } \\
\text { cost. }\end{array}$ & $\begin{array}{l}\text { Increased investment in chargers, higher electricity } \\
\text { consumption charges due to usage of day electricity, } \\
\text { potentially high electricity demand charge }\end{array}$ \\
\hline $\begin{array}{l}\text { Slow overnight } \\
\text { charging }\end{array}$ & $\begin{array}{l}\text { Minimum investment in charging, simple } \\
\text { to manage and usage of low-cost night } \\
\text { electricity. }\end{array}$ & $\begin{array}{l}\text { If this is the only charging approach used, then } \\
\text { the vehicle will require a large battery set to have } \\
\text { sufficient driving range, making the vehicle costly and } \\
\text { heavy. }\end{array}$ \\
\hline Battery Swap & $\begin{array}{l}\text { Less battery requirement on the bus if } \\
\text { sufficient battery swap stations are available } \\
\text { nearby. }\end{array}$ & $\begin{array}{l}\text { Requires costly infrastructure and a larger amount of } \\
\text { batteries in total, limited flexibility as battery-swap } \\
\text { systems are tied to vehicle brands }\end{array}$ \\
\hline
\end{tabular}

a A demand charge is a fee based on the highest rate, measured in kilowatts (kW), at which electricity is drawn during any $15-$ to 30-minute interval in the monthly billing period. This is separate from the charge paid for the actual energy consumed, which is measured in kilowatt-hours.

b On-site batteries can charge and discharge using direct current (DC) and connect to the grid through a large inverter. They can then charge from the grid at times when costs are lower, store the power, and release it when demand is higher. Through this they can also level out the power demand posed on the grid and reduce the demand charge.

Source: Grütter Consulting.

All charging systems formerly described in Table 13 are currently being used by buses (Figure 44).

\section{Slow and Fast Chargers}

Today, most cities in the PRC employ a mixture of slow charging at night with one or multiple fast charges during the day. Many cities also fast charge BEBs during the night, as they lack space for charging the vehicles at their depot and therefore charge them at special charging facilities, moving around the buses during the night. Charging predominantly at night is also due to a night tariff which is significantly lower than day tariffs. Typically, night chargers have a power rating of 50-100 kW and day chargers $150-400 \mathrm{~kW}$, with the majority being 100-200 kW which allows for $50 \%$ charging of most buses in 15-30 minutes.

The number of buses per charger varies largely and depends on the charging power used and the battery capacity of buses. The range is from 1.5 to 10 buses per charger. Most cities use a bus-charger ratio of around three buses per charger. Using $400 \mathrm{~kW}$ chargers instead of $100 \mathrm{~kW}$ chargers reduces the charging time by four times and can thus increase considerably the number of buses per charger. However, it will also require buses to move around and can only park at the charging sites during the charging period. 
Figure 44: Types of Full Electric Buses (Battery Capacity for Standard 12-Meter Bus)

1. Overnight Slow Charging

Battery Capacity

$20-100 \mathrm{~kW}$
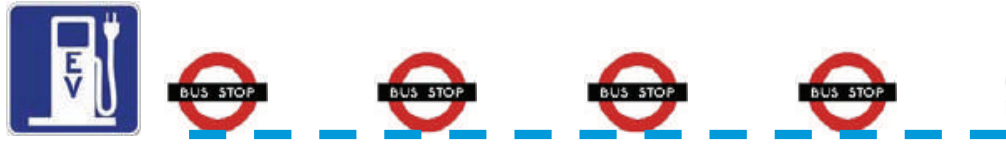

$300-450 \mathrm{kWh}$

2. Fast Intermediate Charging $150-400 \mathrm{~kW}$
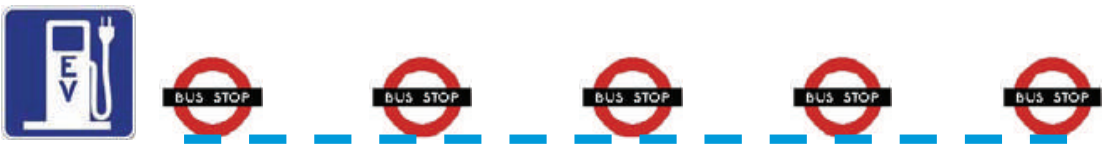

$150-250 \mathrm{kWh}$

3. Intermediate Battery Swapping
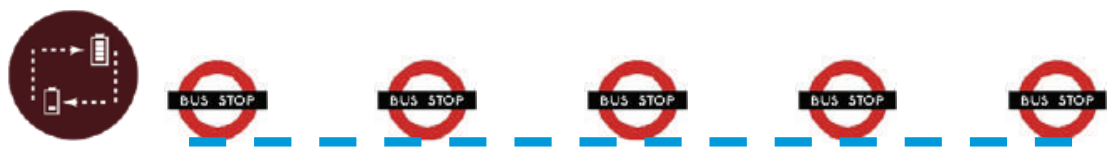

$150-250 \mathrm{kWh}$

4. Opportunity Charge End of Station

20-100 kW 150-600 kW

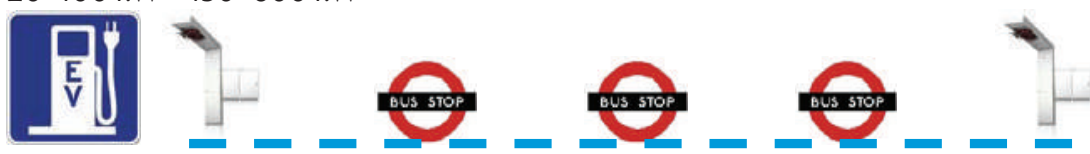

$50-150 \mathrm{kWh}$

5. Opportunity Charge en Route 20-100 kW 400-600 kW
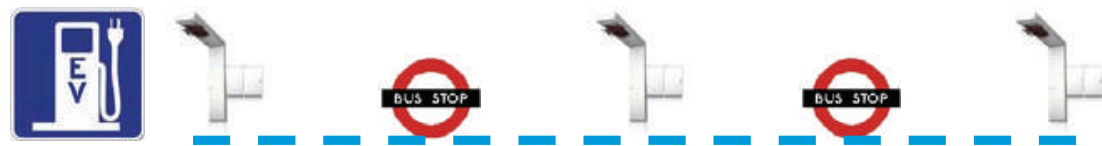

$<50 \mathrm{kWh}$

6. Electric Trolleybus 20-100 kW
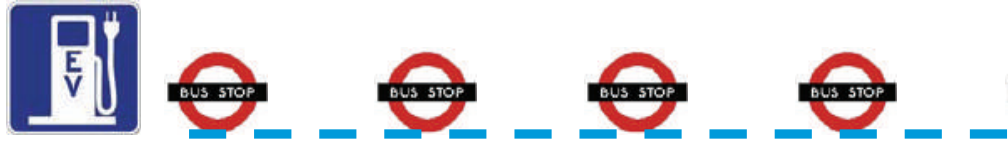

$30-60 \mathrm{kWh}$

$\mathrm{EV}=$ electric vehicle, $\mathrm{kW}=$ kilowatt, $\mathrm{kWh}=$ kilowatt-hour.

Source: Grütter Consulting. 


\section{Battery Swap Facilities}

Battery swap stations were established in various cities in the PRC, which include Beijing, Jinan, Tianjin, and Zhengzhou. Instead of charging the batteries inside bus, robots remove and replace them with new units. This takes around 10-20 minutes, which is comparable to fast charging. Battery swap stations are very expensive to operate-buses need to keep returning to only a few large battery-swap stations, battery swap systems are not standardized and can only be used by units from certain manufacturers, and a large amount of batteries is required. Thus, this approach has been abandoned by cities in favor of fast-charging systems, which requires lower investment, costs less to operate, and far more flexible.

\section{Opportunity Charging}

This is a special form of fast or ultra-fast charging taking place during or at the end of a route. Plug-in hybrid as well as BEBs can be used with such systems. Buses can be equipped with minimal batteries or capacitors. Opportunity charge systems are more popular in Europe than in the PRC.

With end of route systems, fast charging can either be done manually or with pantographs at the end of the route typically using $150-400 \mathrm{~kW}$ chargers. Basically, the reason for using pantographs instead of manual charging is to save on staff costs and to simplify operations. Opportunity charge on the route charges the bus at various bus stops through pantographs or inductive, while taking on new passengers. Ultra-fast high-powered charging is performed with up to $600 \mathrm{~kW}$ in 15-30 seconds. Systems are operated with 12-24-m buses with some systems using buses only equipped with super-capacitors and driving ranges of 5-10 km, i.e., charging is performed every second or third station.

\section{Electric Trolleybuses}

Trolleybuses operate as $12-26-\mathrm{m}$ units in multiple cities worldwide. Modern electric trolleybuses typically have batteries of 40-120 kWh allowing for an autonomy range without catenary of $20-50 \mathrm{~km}$. Thus, they do not require overhead wiring along the entire route, making systems less expensive and more flexible.

Which charging system is optimal cannot be stated in a general manner, as it depends on electricity consumption and power prices (including difference between night, peak, and off-peak tariffs); vehicle and battery costs; cost of the charging infrastructure; and characteristics of the route including route length, bus size, bus frequency, and passenger demand. However, in general, the following trends are observed:

- BEBs with overnight charging plus fast day charging for some units are the optimal solution for buses up to 12-m operating on routes with low to medium passenger demand.

- Opportunity charge systems and trolleybus systems are the optimal solution for bus rapid transit (BRT) routes operating with articulated or bi-articulated units and high frequencies. On such routes, a large number of buses can use the same infrastructure making this approach less costly.

- Battery-swap facilities are not being installed anymore for buses due to very high cost, large amount of batteries required, and system rigidity. Also, the large decline in the cost of fast chargers has made such systems for buses non-competitive. 


\subsubsection{Impact of Electric Vehicle Buses in the People's Republic of China}

\section{Environmental Impact}

Natural gas buses use around 17\% more energy in megajoule per $\mathrm{km}$ than diesel units, while electric buses use four times less energy than fossil fuel units, showing clearly the efficiency of electric traction. Natural gas buses have no advantage compared to diesel units concerning well-to-wheel (WTW) greenhouse gas (GHG) emissions. In the PRC, fuel cell hydrogen-powered vehicles have significantly higher WTW GHG emissions than diesel or natural gas buses due to high electricity usage for hydrogen production using electrolysis or usage of fossil fuel gas if gasification is employed to produce hydrogen. Hybrid and plug-in hybrid buses save on average $20 \%$ fuel. BEBs are very sensitive to usage of airconditioning at high temperatures or heating during winter, which increase electricity consumption by $50 \%$.

Electricity production in the PRC is still dominated by fossil fuel power plants resulting in an average national grid factor of around 0.8 kilogram of carbon dioxide equivalent per kilowatt-hour $\left(\mathrm{kgCO}_{2} \mathrm{e} / \mathrm{kWh}\right)$. However, even with this fossil fuel-dominated grid, electric buses still reduce WTW GHG emissions by around 30\% (Figure 45).

Local environmental impacts of electric buses (including air pollution and noise) are important and positive. However, application of stringent emission standards (the Chinese National Standard V [CN V], equivalent to Euro $\mathrm{V}$ is currently in force) have also reduced emissions of air pollutants (including nitrogen oxide $\left(\mathrm{NO}_{x}\right)$ and particle matter of fossil fuel-powered buses.

\section{Figure 45: Average Well-to-Wheel Greenhouse Gas Emissions of Urban Buses in the People's Republic of China, 2016}

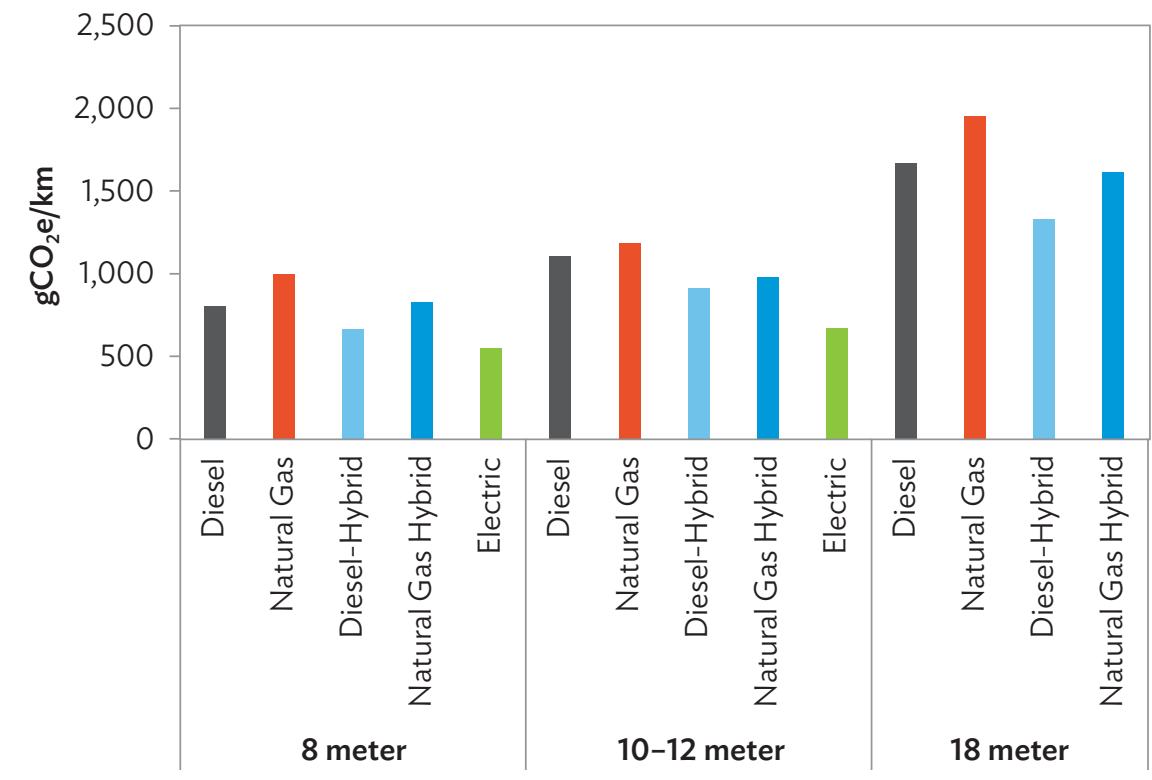

$\mathrm{gCO}_{2} \mathrm{e} / \mathrm{kWh}=$ gram of carbon dioxide equivalent per kilowatt-hour, PRC = People's Republic of China. Source: ADB. 2018. Sustainable Transport Solutions: Low-Carbon Buses in the People's Republic of China. Manila, based on operators in PRC cities. 


\section{Figure 46: Capital Expenditure Comparison With versus Without Subsidies- Standard Urban 12-Meter Bus in the People’s Republic of China, 2016-2017}

$(\$)$

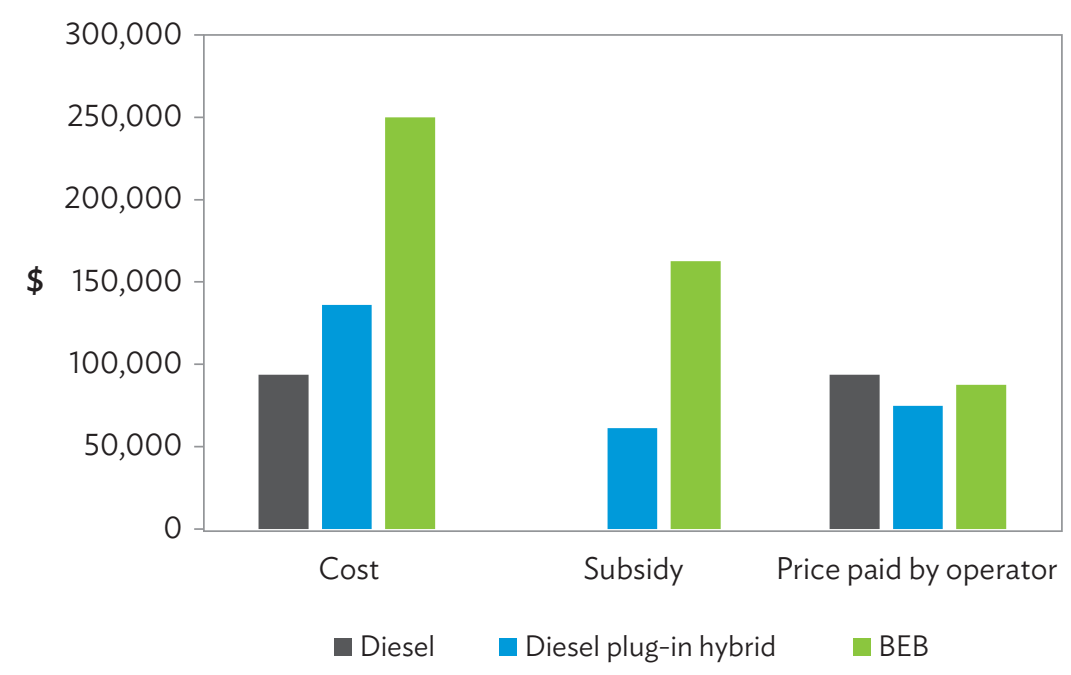

$\mathrm{BEB}=$ battery electric vehicle, $\mathrm{CN} V=$ Chinese National Standard V.

Note: 12-meter standard bus with air-conditioning and one-step entry; diesel version emission standard CNV.

Source: ADB. 2018. Sustainable Transport Solutions: Low-Carbon Buses in the People's Republic of China. Manila.

\section{Financial Impact}

Investment costs on buses vary between cities depending basically on bus specifications. Gas-powered buses have, on average, an incremental cost compared to diesel units of less than $10 \%$. Compared to conventional fossil fuel units, using hybrid buses result in an additional investment of $20 \%-25 \%$, plug-in hybrids at $40 \%-50 \%$, and BEBs at $100 \%-150 \%$. However, as of 2017 , subsidies in the PRC fully cover all incremental costs of low-carbon buses (LCBs) and make their purchase less expensive than conventional buses.

LCBs have higher bus investment costs but lower operational expenditures due to lower costs for energy and, in the case of BEBs, lower maintenance costs. General maintenance costs of BEBs are lower than of conventional units, but BEBs have a $20 \%$ higher tire usage accounting for around $40 \%$ of the total maintenance costs of buses. Conventional and hybrid units are within a comparable range in terms of total cost of ownership (TCO). In the PRC, BEBs have around 30\% higher TCO compared to conventional buses (Figure 47).

The TCO of BEBs would be comparable to conventional units if they were used for 16 years instead of 8 years (using two battery cycles). In cities in the PRC, on average, buses are used only for $600,000-700,000 \mathrm{~km}$, while in most cities worldwide, buses are used for 1 million-1.2 million $\mathrm{km}$. The longer the lifetime mileage, the more profitable BEBs are due to lower operational costs. Using electric buses for a longer period than conventional units also improves their relative profitability. 


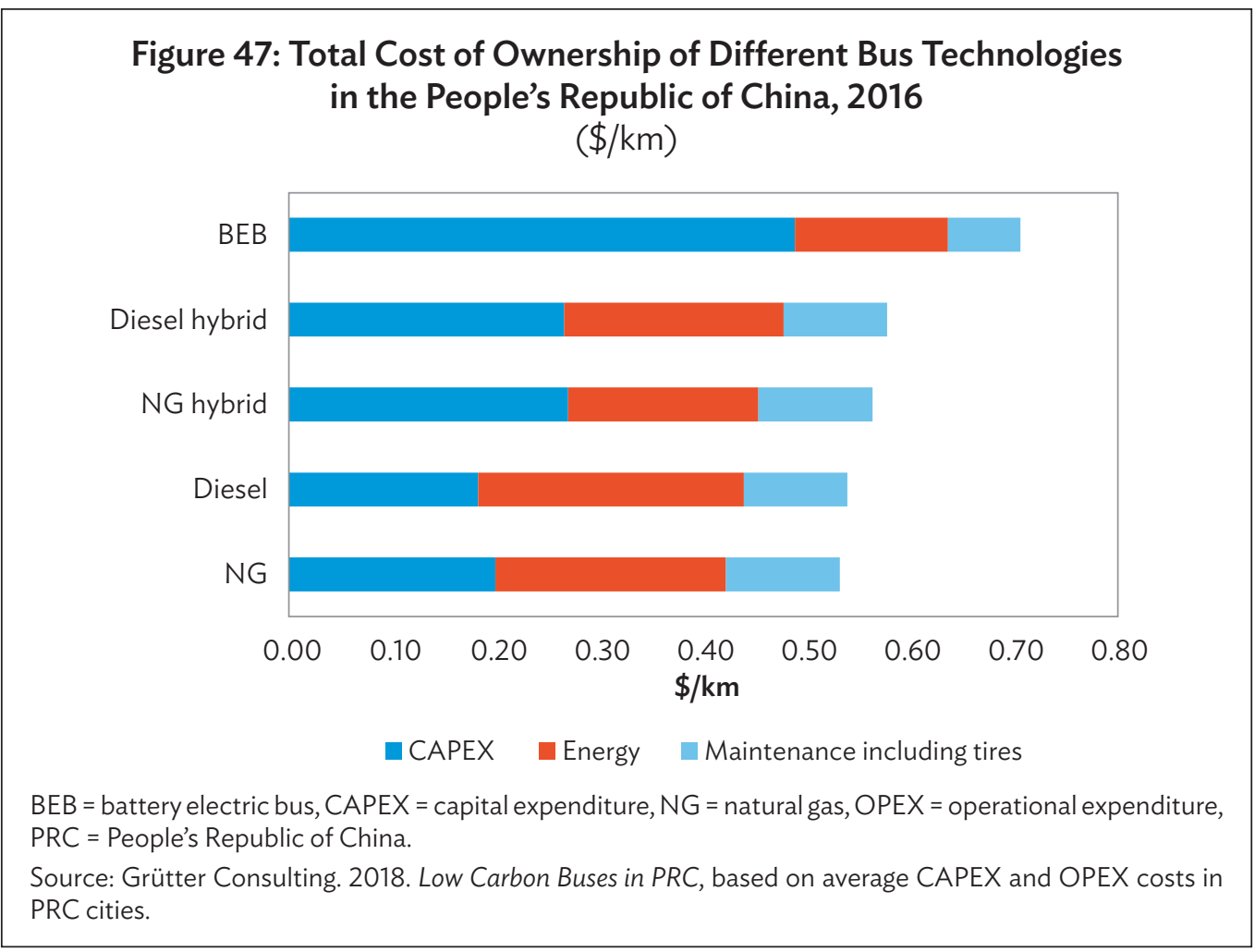

\subsubsection{Success Factors and Critical Elements}

The main success factor is the large uptake of e-buses in cities in the PRC. BEBs are, as of today, reliable and cities have proven that public transport systems can be run fully with e-buses. High up-front BEB subsidies have been very effective in convincing bus operators to purchase e-buses. BEBs have a lower purchase cost than conventional buses while also having a lower energy and maintenance cost. Subsidies are higher than the actual incremental cost of BEBs based on TCO. However, this is justified as BEBs are riskier for bus operators due to the novelty of the technology and unknown actual operational costs. But with operators managing large fleets of BEBs for a few years now, the risks have been reduced and subsidy levels can be lowered. The policy of the government to start with high-subsidy levels and then reducing them gradually is thus considered appropriate.

Up-front CAPEX subsidies are simple and send clear signals to bus operators, thus making the uptake of e-buses faster. However, if operators are tied to certain bus types and technology approaches, this can result in purchase of suboptimal bus types and sizes, and favor certain approaches to bus electrification. Once the initial hurdle of managing a substantial e-bus fleet has been overcome, a more effective and efficient instrument might be to relate subsidies to electric bus usage (i.e., relate subsidies to actual e-bus passenger-kilometers driven). ${ }^{102}$ Such a subsidy system would be technology- and size-neutral. Some provinces and cities are discussing to establish annual subsidies relative to the distance driven of e-buses (e.g., in Guangzhou). This would be a step in this direction.

102 Relating the subsidy to passenger-km and not only to bus-km avoids favoring smaller buses. Passenger km can be theoretically calculated based, for example, on $50 \%$ of the maximum passenger capacity multiplied with the annual distance driven. 
The PRC has vast experience in operating LCBs successfully. Many cities are going toward full electrification of bus services as e-bus technologies become more available. The use of hybrid buses in the PRC as well as in other countries is an intermediate step toward full electrification, with hybrids basically used for high-demand routes and bigger buses. Plug-in hybrids have not resulted in additional benefits compared to hybrids in the case of the PRC, as operators do not charge them at the grid. For other countries, a direct step from conventional buses toward e-buses can be feasible as reliable electric technologies are available today for all types of routes and buses, i.e., the conventional buses-hybridsplug-in hybrids-e-buses is today not necessarily the optimal path for a given city.

Bus operators need to optimize the e-bus system configuration for different types of e-bus technologies, battery size, and charging technology. Parameters such as route distance, e-bus performance in the summer with air-conditioning usage, battery reserve rates, and battery capacity decline over time, need to be considered to determine battery sizes of buses under different charging regimes. The optimal system configuration will depend on technical and route criteria, electricity prices, and bus costs. In general, pure battery e-buses are best used as smaller and medium-sized units operating at shorter routes with intermediate fast charging for buses operating longer routes, while bus routes with high frequencies and high passenger demand are best operated by opportunity charge systems and electric trolleybuses.

An important factor is also that e-buses have a positive impact on reducing GHG emissions even in the context of a fossil fuel-dominated grid. However, further reductions in the PRC will only be possible if the electricity production shifts more toward renewables.

\subsection{Electric 3-Wheelers in Nepal}

\subsubsection{Country Circumstances}

Nepal has a zero-grid factor as all its electricity production is based on renewables. New vehicles have to comply with the Euro 3 standard. Kathmandu is well-renowned for having serious air pollution problems and fuel prices are, at least in recent years, slightly above the median for DMCs of ADB, thus creating a favorable condition for the promotion of EVs. Nepal has also various incentives schemes in place to promote EVs.

Two ventures concerning electric 3-wheelers are discussed:

- E-rickshaws (Safa Tempos) introduced in the 1990s, but without further expansion after year 2000.

- $\quad$ E-pedicabs to replace bicycle rickshaws introduced by ADB in 2017.

\subsubsection{Core Features}

Electric 3-wheelers were introduced in Kathmandu in 1993 with a United States Agency for International Development (USAID)-financed project converting diesel 3-wheelers into e-rickshaws (Safa Tempos or e-Safas). In 2000, some 600 electric 3-wheelers plied the streets of Kathmandu ${ }^{103}$ while more than 4,000 fossil fuel 3-wheelers were also on the streets.

Safa Tempos were assembled in Kathmandu with parts from India and the US and can transport up to 12 passengers with a drive range of $55 \mathrm{~km}$ and a battery life span of 18 months using deep-cycle lead-acid batteries. Each vehicle has at least two sets of batteries and some 40 battery charging and exchange

103 CEN, undated. 
stations were located at convenient points along main routes. The government does not charge any value-added tax and only $1 \%$ custom duty for the import of EV components and EVs do not have to pay the annual vehicle tax. ${ }^{104}$ The ban on diesel rickshaws in 1999 gave a decisive push toward e-rickshaws, with numbers increasing from 200 units prior to the ban to 600 units a year after the ban. After 2000, no new e-rickshaws were purchased as the government allowed for the import of petrol-and LPG-powered rickshaws as well as diesel microbuses with very similar reduced customs tariffs given to EVs. ${ }^{105}$ The government thereafter banned the entry of new 3-wheelers, including the e-Safas, to Kathmandu.

E-pedicabs in a modern design were initiated by ADB and started to hit the roads in Lumbini and Kathmandu on a trial basis in 2017. In contrast to motorized rickshaws, bicycle rickshaws are basically used for last-mile connectivity, transport only a maximum of two passengers, and are confined to certain routes, e.g., in Kathmandu, around a tourist area. ${ }^{106}$ While electrified pedal rickshaws have been in use in Asian countries, there are differences between these motorized e-rickshaws introduced in Kathmandu and existing e-pedicabs:

- Modern, lightweight design of e-pedicabs with special customer features such as an on-board tablet device.

- E-pedicabs can pedal-assisted while electric-assisted rickshaws are too heavy and chain-runs are often impeded due to frame modifications, i.e., if the battery is empty, e-pedicabs can still operate while conventional battery-assisted pedal rickshaws cannot.

- Use of lithium-ion batteries instead of heavy, short-lived lead acid batteries, which have a high environmental cost when disposed.

\subsubsection{Impact}

Annual GHG reductions for the 600 e-Safas are around 2,200 tons of carbon dioxide $\left(\mathrm{tCO}_{2} \mathrm{e}\right)$ tank-towheel (TTW) to $2,700 \mathrm{tCO}_{2} \mathrm{e}\left(\mathrm{WTW}\right.$ ) 107 or around $4 \mathrm{tCO}_{2}$ e per vehicle per annum. The commercial viability of e-rickshaws was linked to the ban on diesel units and financial benefits not available to fossil fuel units. Total costs of operation, including capital expenditure (CAPEX) and operational expenditure (OPEX), are around 30\% higher for e-Safas than for diesel microbuses. ${ }^{108}$ An evaluation of social costs and benefits shows that e-rickshaws are economically more profitable than fossil fuel units, ${ }^{109}$ i.e., there is a case for subsidizing EVs.

E-pedicabs would not only replace existing bicycle rickshaws, but also provide for an enhanced service, which can attract users of taxis, buses, or even private cars due to being a door-to-door service at a low cost and with a comfortable riding experience. While they do replace also zero-emission trips such as cycling, bicycle rickshaw, and walking, e-pedicabs also have the potential to replace motorized trips. A pilot fleet of 60 e-pedicabs is now under testing in Lumbini ${ }^{110}$ and e-pedicabs have been included as last-mile connectivity vehicles for the Karachi BRT red-line project of the ADB. However, no monitoring

104 CEN, undated.

105 Bhatta, S. D. and D. R. Joshi. 2014. Are Electric Vehicles Viable in Kathmandu? A Cost-Benefit Perspective. Washington, DC; 300 such diesel microbuses were introduced 2002-2004.

106 As of 2017, around 200 units were operating in Kathmandu and 125 in Lumbini (ADB. 2017).

107 Based on mileage of 18,000 km/a, $0.267 \mathrm{kWh} / \mathrm{km}$; diesel microbus with $10 \mathrm{l} / 100 \mathrm{~km}$ and 30\% higher passenger capacity; input data based on Bhatta, S. D. and D. R. Joshi. 2014. Are Electric Vehicles Viable in Kathmandu? A Cost-Benefit Perspective. Washington, DC, Table 5.1.1; calculations by Grütter Consulting.

108 Bhatta, S. D. and D. R. Joshi. 2014. Are Electric Vehicles Viable in Kathmandu? A Cost-Benefit Perspective. Washington, DC, Table 5.1.2.

109 Bhatta, S. D. and D. R. Joshi. 2014. Are Electric Vehicles Viable in Kathmandu? A Cost-Benefit Perspective. Washington, DC.

110 Basically for moving people from the town to the nonmotorized temple areas. 
data is available to determine the potential GHG impact of e-pedicabs. E-pedicabs consume around $0.5 \mathrm{kWh}$ per day of electricity which would allow for full charging, e.g., through a 250-watt photovoltaic system. The CAPEX of an e-pedicab is currently around $\$ 2,500$, making it financially nonviable compared to a bicycle rickshaw or a motorized unit. ${ }^{111}$

\subsubsection{Success Factors and Critical Elements}

A major critical factor in the rise and fall of e-rickshaws in Nepal was inconsistent government policy and opposition from interest groups of fossil fuel vehicle owners, which had very close links to the government. Conventional diesel 3 -wheelers were banned in 2000, but at the same time subsidies were given to microbuses to replace them and LPG 3-wheelers were allowed (with LPG subsidized by the government). Also, allegations of battery pollution undermined the image of e-Safas. Batteries were also deteriorating faster than expected, occurring after a year. The government then banned all 3-wheelers, including electric units alleging oversupply of vehicles and clearly favoring diesel microbuses. ${ }^{112}$

The biggest potential for e-pedicabs is basically for last-mile connectivity and for urban centers with limited access to motorized vehicles. For other applications, e-pedicabs will compete with e-rickshaws, which have more power, higher speed, and can carry more passengers and cargo (see also cases in Dhaka and Udaipur in Chapter 11).

\subsection{Battery Swap Scooters in Taipei,China}

\subsubsection{Country Circumstances}

Taipei,China has an electricity grid factor of $0.60 \mathrm{kgCO}_{2} \mathrm{e} / \mathrm{kWh},{ }^{113}$ which is equal to the median of all DMCs of ADB. Scooters represent nearly $70 \%$ of Taipei,China's 22 million registered vehicles. Domestic EV penetration has been slow in Taipei,China and gasoline scooters are still the norm. The government has set as target that all scooters by 2035 will be electric. Despite multiple subsidies, only around 110,000 electric scooters or e-scooters are registered as of end 2016, out of a total of 15 million 2-wheelers in the country. ${ }^{114}$ Prior efforts to promote e-scooters have failed, but recently sales numbers have picked up because of a new startup called Gogoro. ${ }^{115}$

\subsubsection{Core Features}

Gogoro started selling e-scooters in June 2015. Its strategy is based on a battery swapping system, building a network of unmanned stations that allow customers to exchange drained batteries for freshly charged units. Many of these swapping stations are located in front of convenience stores. Used batteries are simply dropped into a slot, and charged units pop out. This way, there is no need to find a socket and wait for a full charge. ${ }^{116}$

111 Once e-pedicabs are mass produced, prices are expected to drop to around $\$ 1,500$ per unit.

112 See for a detailed analysis of causes of failures which resulted in a failure of the EV industry. Maharja, S. 2002. Electric Vehicle Technology in Kathmandu, Nepal: A Closer Look at Its Development.

1132015 data based on IEA, 2017c for GHG emissions and IEA for electricity production minus losses.

114 Lin. 2018.

115 A similar model is also being used by Kymco and the battery swap system lonex; M. Völklein. 2018. E-scooter Many EV should usher in revolution. Tages Anzeiger. 5 June. https://www.tagesanzeiger.ch/auto/zweirad/EScooter-Many-EV-sollRevolution-einlaeuten/story/25320492.

116 K. Ihara. 2017. Asia Nikkei Review. 23 February. 
Gogoro scooters cost from $\$ 2,200$ to $\$ 3,800$ with speeds reaching up to $95 \mathrm{~km}$ per hour. The basic model has a maximum power output of 6,400 watts ${ }^{117}$ and a lithium battery with a charging time of 2.5 hours (1,000 cycles) and a maximum range of $100 \mathrm{~km}$ if the battery is new (but more realistically $80 \mathrm{~km}$ ). The current monthly subscription fee for the battery swap station usage is $\$ 25 .{ }^{118}$

Gogoro is the market leader for e-scooters in Taipei,China and has installed around 700 battery swapping stations in different cities. It also recently opened its battery swapping network to all other e-scooter makers as part of its plan to tap into the global market. To be compatible with Gogoro's battery swapping network, however, other e-scooters need to be equipped with Gogoro's control units. Users also have to subscribe to the Gogoro app and pay a monthly fee to access its battery swapping stations. While the user owns the motorcycle, the batteries are owned by Gogoro and the user needs to subscribe to a membership to gain access to the battery swapping network (battery reservation can be done through the app). The company also installed its first solar-powered battery swapping station using $2.3 \mathrm{~kW}$ solar panels generating up to $6.2 \mathrm{~kW}$ of electricity daily.

Gogoro uses algorithms to optimize where to distribute battery inventory and when to charge its batteries. Thus, it can also take advantage of charging when prices are low and avoids overstressing the grid. Rather than simply a manufacturer of e-scooters, the company now sees itself becoming more of an energy utility, offering city-wide battery storage and feeding back into the power grid, if needed. ${ }^{119}$

Central and local governments subsidize e-scooters from $\$ 240$ (small scooter) to $\$ 1,200$ (central plus local subsidies, including subsidy if a two-stroker is eliminated). The government also subsidizes up to $50 \%$ of the costs of building charging stations, although the subsidy caps at $\$ 10,000 .{ }^{120}$ Nonfinancial incentives include exclusive parking spaces, preferential parking fees, and prohibition for two-strokers in certain areas.

\subsubsection{Impact}

In Taipei,China, having 110,000 e-scooters on the road helps reduce annual GHG emission by around $56,000 \mathrm{tCO}_{2}$ e annually. ${ }^{121}$ If all 15 million 2-wheelers would be electric, GHG reduction would amount to $7.7 \mathrm{MtCO}_{2}$ e annually representing around $20 \%$ of Taipei,China's transport emissions. ${ }^{122}$ While the annual sales growth of e-scooters is impressive, the absolute numbers are still very low and Taipei,China's target of replacing all conventional gas scooters is far off. The current market share is less than $1 \%$ and is below $2 \%$ of new vehicle sales, which indicates that the e-scooter market has yet to take off.

The cost of the motorcycle and access to its battery swapping system is a challenge for Gogoro, which basically targets higher-end customers. The monthly subscription fee alone is equivalent to the gasoline costs of driving a conventional scooter in Taipei,China, logging around 900-1,000 km in a month. This is already higher than the average monthly mileage of $500-600 \mathrm{~km},{ }^{123}$ i.e., gasoline scooters will not only be cheaper to purchase but also cheaper to operate, making it unrealistic to assume they can be

\footnotetext{
117 As comparison electric scooters sold in India have mostly a power range of 250-500 watts (w) with few reaching 1,500 w.

118 Gogoro. https://www.gogoro.com/.

119 K. Hao. 2017. The future of transportation may be about sharing batteries, not vehicles. Quartz. 25 September. https:// qz.com/1084282/the-future-of-transportation-may-be-about-sharing-batteries-not-vehicles/.

120 Lin, 2018.

121 WTW calculation using the grid factor of Taipei,China with average mileage and energy consumption of e-scooters and comparable gasoline units; calculation by Grütter Consulting; see Annex 1 for datasets.

122 Based on Taipei,China EPA, 2016.

123 IEA. 2018b. Global EV Outlook 2018. Paris, assumes 6-7,500 km/a.
} 
readily replaced with e-scooters unless the up-front cost for the latter declines along with access to the charging system, or financial and nonfinancial incentives increase.

\subsubsection{Success Factors and Critical Elements}

From 1998 to 2002, Taipei,China's Environmental Protection Administration spent $\$ 60$ million on e-scooter subsidies, reducing costs to a level comparable to gasoline-powered motorcycles. However, the program inefficiently stimulated demand due to a lack of consumer confidence in battery reliability and insufficient charging infrastructure. In the PRC, without massive government subsidies, e-scooters dominate the market with more than 200 million units. ${ }^{124}$ The main differences are nonfinancial incentives, which in fact have not been targeted toward e-scooters, but have effectively worked in their favor. Nearly every major city in the PRC has banned gasoline-powered motorbikes, but electric bicycles (or e-bikes) and scooters are frequently classified as non-motorized transportation due to being equipped with (decorative) pedals, thus exempting them from motorcycle prohibition.

Prior to the late 1990s, the PRC attempted to promote electric motorcycles but without much success. The rapid uptake of e-scooters happened when they became the only alternative for users if they wanted to use a two-wheeler in cities. Thus, the primary driver behind the e-scooter boom was the ban on motorcyles based on arguments that motorcycles disrupt traffic and cause congestion, and are a safety hazard and cause air pollution. E-scooters do create less air pollution, but are no different from gasoline motorcycles in impact on congestion and road safety. The loosely enforced e-scooter standards, however, allowed e-scooters to continue operations, although some cities in the PRC are now also banning or restricting the use of e-scooters. ${ }^{125}$

\subsection{Electric Car-Sharing Program in Singapore}

\subsubsection{Country Circumstances}

Singapore has a grid factor of $0.42 \mathrm{kgCO}_{2} \mathrm{e} / \mathrm{kWh},{ }^{126}$ which is in the lower half compared with other Asian countries. The EV market is not well developed, but the city has recently launched the electric carsharing scheme BlueSG, ${ }^{127}$ which aims to reduce the number of vehicles on the city's roads and encourage citizens to use public transport and drive zero-emission cars.

\subsubsection{Core Features}

The service will be operated for a decade by BlueSG, a unit of the Ballore Group of France which runs similar schemes in other cities worldwide-the most famous being in Paris, which was folded down recently (see discussion below). The target is to have a fleet of 1,000 vehicles and 500 charging sites each with four parking spaces by 2020 (the system started in December 2017 with 80 cars and 32 stations). EVs used are four-seaters using a lithium-metal polymer battery with a maximum driving range of $200 \mathrm{~km}$. The driver is notified to return the vehicle if the state of charge (SOC) drops to less than $30 \%$. Cars can be parked and charged at any of BlueSG station.

124 IEA. 2017b. Global EV Outlook 2017. Paris.

125 Yang, C. J. 2010. Launching Strategy for Electric Vehicles. Technological Forecasting and Social Change 77. 831-834.

126 Published by the Energy Market Authority (EMA). https://www.ema.gov.sg/cmsmedia/Publications_and_Statistics/ Publications/SES17/Publication_Singapore_Energy_Statistics_2017.pdf; this grid factor is also used for EVs, see: Land Transportation Authority. Emission Factor for Electric and Plug-in Hybrid Vehicles under the Vehicular Emissions Scheme. https://www.lta.gov.sg/apps/news/page.aspx?c=2\&id=0f05bf29-8c68-469e-bf9e-19808f1ddb13.

127 Information based on BlueSg www.bluesg.com.sg. 
The service charges users $\$ 0.24$ per minute with an annual membership cost of $\$ 130$ or $\$ 0.37$ per minute without membership. Users can reserve parking or charging slots in advance through a mobile app.

\subsubsection{Impact}

In its first 2 months, BlueSG was operating 105 cars logging in a monthly total of $200,000 \mathrm{~km}$ or around $60 \mathrm{~km}$ per car per day (or around $23,000 \mathrm{~km}$ a year). Car sharing has the potential to reduce private car usage while encouraging users to use public transport. This assumption has been corroborated by in-depth evaluations of car-sharing users in Switzerland, which has in relation to its population the largest car-sharing program of the world, as well as being one of the first such systems established. ${ }^{128}$ However, this impact would be achieved with any car-sharing scheme, whether it is using conventional vehicles or EVs. Other car-sharing companies are also operating in Singapore, the largest being CarClub. Therefore, the impact of having an EV car-sharing scheme is related to the usage of EVs compared to other car-sharing companies in Singapore that use gasoline cars. Compared to a conventional fossil fuel car, an EV unit saves around $1.5 \mathrm{tCO}_{2}$ per annum, ${ }^{129}$ i.e., with a target fleet of 1,000 vehicles, around $1,500 \mathrm{tCO}_{2}$ could be saved annually. ${ }^{130}$

\subsubsection{Success Factors and Critical Elements}

While car-sharing reduces usage of private cars as more people use a mix of mobility alternatives, there are questions to whether EVs are a suitable alternative for car-sharing schemes. Autolib, which was started in 2011 by the Ballore Group of France, owned 4,000 EVs, but ended its operations in June 2018. The Paris city government terminated its contract 5 years ahead of expiry due to huge losses which amounted to more than $\$ 50$ million annually; Ballore originally stated that the service would be profitable. ${ }^{131}$

On average, Autolib cars were used less than five times a day. The city government wants to replace the scheme with a "free-floating" car-sharing system, which would allow users to book and return the vehicle at any point without having to go to one of the charging points - a far more convenient option for users. Free-floating car sharing has grown in Europe faster and more popular than services where cars need to be returned to designated parking spaces or to their original departure points. People are also increasingly using different modes of ride-hailing services like Uber, electric moped rentals, and multiple dockless bike operators such as Ofo and Mobike. ${ }^{132}$ Other car-sharing schemes such as Zipcar or Drivy are also available in Paris and cost lower and are more convenient to use. This is also true for Singapore, where an economy car at CarClub is less than half of the cost charged by BlueSG, which charges $\$ 0.06$ per minute for members and $\$ 0.11$ per minute for non-members. ${ }^{133}$

Electrifying car sharing is an interesting option especially with increased public acceptance and thus promotes e-mobility. However, it also faces some important challenges including:

- If vehicles have to be returned to charging points, it makes the system less convenient for customers and reduces the usage rate of vehicles. Free-floating systems are the benchmark for

\footnotetext{
128 Interface. 2006. Evaluation Car-Sharing. Bern.

129 This is far less than claimed by BlueSG.

130 Calculated by Grütter Consulting based on Nissan Note CarClub using a WTW approach; see Annex 1 for details.

131 This amounts to an annual subsidy per car of $\$ 13,500$.

132 For example, see AFP, 23 June 2018 or RFI. 2018. Paris puts an end to electric car sharing system Autolib. 22 June. http:// en.rfi.fr/france/20180622-paris-puts-end-electric-car-sharing-system-autolib.

133 CarClub SG. Rates \& Stations. https://www.carclub.com.sg/rates-and-cars/.
} 
a modern customer-oriented car-sharing scheme, which allow users also to realize one-way trips. Free-floating car sharing systems with EVs are operating, for example, in Germany and use incentives such as free minutes of car usage if users park and charge EVs at charging stations. ${ }^{134}$ However, to implement a free-floating system with EVs requires a high density of public chargers and, if car-sharing vehicles are not used sufficiently, this might block charging stations from being used by other clients.

- Users might not want to use vehicles which are not fully charged to avoid having to interchange the vehicle at some charging space (thereby losing time and money as vehicles are paid per minute). This results in low daily usage rate per vehicle.

- Overall costs of the system are high due to low usage rates and high infrastructure costs, making the system unprofitable.

In general, car-sharing in its traditional form (like a rental system where cars are returned to their site of origin) is considered outdated for urban centers and short trips, while still attractive for longer trips and longer rental periods. Urban users are increasingly becoming multimodal, with options including ridehailing services, dockless bike-sharing systems, moped and e-bike systems, public transport and freefloating car sharing. With autonomous vehicles, car sharing and ride-hailing services will eventually merge.

Using EVs in car sharing is considered an interesting option (and helps promote EVs among private car users), but will require either a network of public rapid charging stations or a sufficient density of public charging stations to be operated in a free-floating system. Also, without subsidies, such systems will hardly be able to operate initially, unlike conventional car-sharing systems, due to higher vehicle cost as well as lower usage rates. Other ride-hailing systems like Uber could also be of interest to connect with EVs. Uber London, for example, offers certain, albeit still limited incentives for their drivers to go electric. ${ }^{135}$ Didi in the PRC claims to operate 260,000 EVs and has launched a charging network to support its drivers. ${ }^{136}$ Annual mileage is much higher in these systems and charging is much simpler as they are not used by multiple drivers for non-connected trips.

\section{CONCLUSIONS AND RECOMMENDATIONS FOR ACTIONS}

\subsection{Conclusions}

The electric vehicle (EV) market is growing strongly, albeit from a low base level. Growth is concentrated in relatively few countries and cities. The People's Republic of China (PRC) has by far the largest EV market. Cities are a good starting point for promoting EVs as they accommodate large numbers of commercial vehicles including buses, urban trucks, and taxis, as well as car-sharing facilities, all of which can be converted to EVs at lower cost than private passenger vehicles. Cities are also prone to high levels of air and noise pollution where EVs can make a real difference.

The major barrier to the widespread adoption of EVs is the high up-front investment. Most countries that invested in EVs have only partially recovered their investment with lower energy and maintenance costs.

134 L. Stresing. 2015. Free rides for the store. Der Tagesspiegel. 4 August.https://www.tagesspiegel.de/mobil/alternative-antriebe/ elektrisches-carsharing-freifahrten-fuers-laden/12128416.html.

135 Uber. Electric Vehicle Programme. https://www.uber.com/en-GB/drive/resources/electric-vehicle-programme/.

136 F. Lambert. 2017. Didi (People's Republic of China's Uber) claims to be 'world's largest EV fleet operator' with 260,000 EVs, launches charging network. electrek. 11 March. https://electrek.co/2017/11/03/didi-china-uber-worlds-largestev-fleet-operator-charging-network/. 
The lack of charging points is also a major barrier especially for private cars, while questions concerning reliability of the technology are more important for commercial customers.

The environmental impact of EVs is basically on reducing greenhouse gas (GHG) emissions and, especially in the case of substituting diesel vehicles, reducing air pollution and noise. The GHG impact of EVs is positive with most electricity grids, even if upstream manufacturing emissions of the vehicle and battery are included. However, greening the grid is important for countries which have levels of more than 0.8 kilogram of carbon dioxide equivalent per kilowatt-hour $\left(\mathrm{kgCO}_{2} \mathrm{e} / \mathrm{kWh}\right)$ as the impact of EVs will only be limited.

Vehicle and charging technology, policies, and business models are distinct relative to the vehicle category. Policies in most countries focus on and favor private cars, basically through tax exemptions, while commercial vehicles would have a much larger impact on GHG emissions and reducing pollution, in general, due to high mileage and, in the case of buses and trucks, due to high energy consumption. Also, especially for buses, total cost of ownership for EVs is nearly equal to conventional fossil fuel units in many countries, thus not requiring massive subsidies, but instead new business models based on, for example, vehicle leasing models or separation of vehicle ownership and vehicle operations allowing for the introduction of less costly units.

Most countries already have low tax levels for all types of commercial vehicles, such as buses, trucks or taxis, and therefore EVs do not profit much-in contrast to private cars. Other policies are therefore required to stimulate commercial EVs, including compensation for their impact on air pollution and noise, preferential access to urban centers, preferential licensing (e.g., taxis), or obligations to operate a certain share of EVs (e.g., for buses), which can be gradually increased.

Electric 2-wheelers and 3-wheelers have been taken up in many countries, albeit with problems. The electric units deployed are often of low quality, equipped with lead batteries with a very short life span and with environmental disposal problems, and vehicle convenience is not the same with gasoline or diesel or compressed natural gas (CNG) units in terms of power, driving range, and speed. While the low purchase price of such electric units makes them an attractive option, users need to invest in costly new batteries after around 1 year.

EVs are also not as comfortable as conventional vehicles, making them attractive to a certain customer segment (e.g., in the case of electric scooters, for students as no license is required). Comparable EVs of the same vehicle category (with a similar power, speed, and, driving range) are equipped with lithium-ion batteries and have higher-powered motors, resulting to significantly higher costs and clearly surpassing conventional vehicles.

Conventional motorcycles, meanwhile, have a very low purchase and operational cost, making them more affordable and convenient. Electric units with comparable features are far costlier to purchase and the energy cost savings will not be impressive for a client. The experience of Taipei,China also shows that even with purchase subsidies, it will be very hard to achieve significant shares of electric motorcycles or e-motorcycles. For this category, it is important to have policies in place that either ban fossil fuel units or create very strong nonfinancial incentives which clearly favor e-motorcycles (such as exclusive access to the city center or exclusive parking spaces). Cost-parity for e-motorcycles might not constitute a sufficient incentive to switch.

\subsection{Policy Focus}

A set of recommendations for actions and policies are given for the deployment and maximum impact with EVs. 


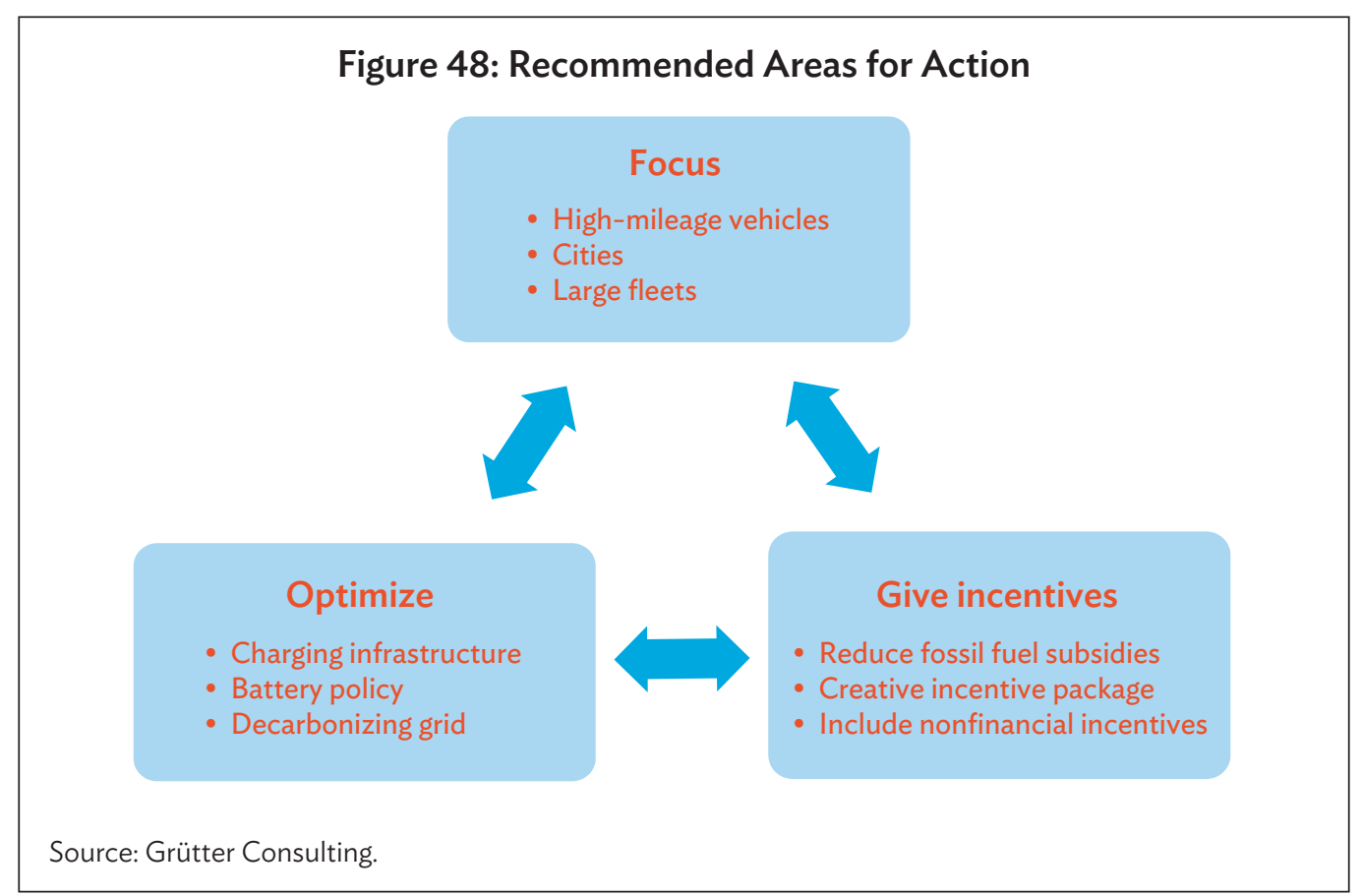

\section{A. FOCUS}

Focus on high-mileage EVs. High-usage vehicles will result in a significant reduction in GHG emissions and overall environmental impact while the financial profitability of such EVs is also better as the higher capital expenditure (CAPEX) is compensated quicker with lower operational costs due to high mileage. This means targeting buses, trucks, taxis, mobility-as-a-service providers, car sharing, and rickshaws.

Focus on cities. A focus on EVs used primarily in cities reduces the need for costly charging infrastructure and provides for the highest impact on air pollution as this is primarily a concern in urban areas. Charging infrastructure can be shared, for example, between buses, urban delivery trucks, and taxis. The focus on cities also complements the focus on high-mileage vehicles, with exception of long-haul buses and trucks which are technically more difficult to electrify with only limited options currently available in the market.

Focus on large fleets. A focus on fleet managers and on large fleets allows for a significant impact and reduces costs. Small number of EVs will result in large infrastructure costs, and the experience with pilot deployments with small fleets is that purchase and maintenance costs are very high while vehicle availability rates are low. EV deployment might be more effective through leasing companies and vehicle aggregators, especially in countries where transport service providers are small companies.

\section{B. OPTIMIZE}

Explore charging options. Optimized charging infrastructure and vehicle configuration reduces the package cost and can result in renewable energy systems being more attractive. Options include assessing the optimal mix between battery pack and charging type (slow, fast, ultra-fast), solar charging systems, and especially for small island states linking renewable grids with electric cars on a vehicle-to- 
grid (V2G) base. The latter is possible with passenger cars as high-usage vehicles (like buses, trucks, and taxis) either operating or need to be charged, i.e., they only have a limited ability to be used as back-up storage.

Define battery policies. Batteries can be a problem, but can also be a possible solution. Second-life options of EV batteries are potentially an interesting source of revenue. Again, this is much easier realized with large fleets which have a critical mass of batteries. Lead batteries, which are still often used in twoand three-wheeler EVs, have a very limited life span and recycling them is often related with significant environmental and health impacts. Incentives for lead-powered EVs should thus be phased out. At an early stage, battery recycling and re-use policies should be put in place, obliging vehicle vendors to take back batteries and use them in secondary applications (or recycle them). An up-front recycling charge could be lifted from on the sale of batteries, which feeds a recycling and re-usage fund.

Green your grid first. In countries with a grid factor more than $0.8 \mathrm{kgCO}_{2} \mathrm{e} / \mathrm{kWh}$, greening the grid should be the first priority. The impact of EVs on GHG reduction will be small with very high marginal abatement costs. Starting first with EVs or greening the grid in parallel to promotion of EVs is not considered an effective strategy as grid greening, in general, takes far longer (due to the long life span of energy production units) than the average life span of EVs.

\section{GIVE INCENTIVES}

Reduce fossil fuel subsidies. An important parameter affecting EV profitability is fossil fuel price. Reducing fossil fuel subsidies and putting environmental taxes on fossil fuels will promote the shift toward EVs and is equitable as it follows the polluter-pays-principle. Public transport services are best subsidized through direct payments to operators based on operating criteria such as passengerkilometers, number of passengers transported, or operational kilometers under a service contract and not through subsidizing fuels.

Package incentives creatively. Incentives should be targeted toward vehicles with high impact and geared toward sustainable business models. Subsidizing public charging infrastructure in cities is a good start. Incentives are often too much targeted toward private vehicle owners with limited impact and a high cost. Linking subsidies to vehicle usage and mileage is more efficient. Access to capital, guarantee schemes, and nonfinancial incentives should be explored next to traditional up-front subsidies. Nonfinancial incentives have proven to be effective (if sufficiently high), but are very costly. Financial subsidies to private EV owners should be fiscally neutral and be paid by fossil fuel car owners to avoid negative social impacts.

Include nonfinancial incentives. Cities have multiple instruments at their disposal to promote EVs, including unrestricted city access, preferential lanes and parking access, preferential access for electric logistics vehicles, preferential route assignments for electric bus or e-bus operators, and preferential licenses for electric mobility-as-service providers. Such incentives can turn business models based on EV fleets profitable. For motorcycles, financial incentives have proven to be important but not decisive. Even if electric scooters or e-scooters have the same price tag as conventional motorcycles, customers will still be reluctant to purchase them due to issues on range, speed, power, and reliability. The operational costs of gasoline scooters are very low (less than $\$ 0.5$ per day) and, with slightly lower operational costs due to low electricity prices, will not make a significant difference. The core nonfinancial incentive which will promote e-scooters is clearly to ban fossil fuel motorcycles from entering cities. This can be justified based on air and noise pollution caused by fossil fuel units. 


\section{COUNTRY CASE STUDIES}

\subsection{Overview}

Country case studies outline possible policies and/or strategies or business models to promote EVs in a given sector and give an indication of potential impacts. These are not based on successful cases, but assess potentials for EV promotion in a given country. Country studies are structured around different vehicle categories to show a diversity of potential approaches. These focus on cities as EV promotion and accompanying policies are driven largely by cities. Also, urban densities allow for reducing costs of EV promotion. The order of presentation is based on the vehicle category starting with 2-wheelers (in $\mathrm{Ha} \mathrm{Noi}$ ), 3-wheelers (in Dhaka and Udaipur), paratransit (in Manila), passenger cars (in Fiji), buses (in Tbilisi, Yerevan, and Karachi), and urban trucks (in Bangkok).

\subsection{Hanoi: Electric Motorcycles}

\subsubsection{Country and City Facts}

\section{National Circumstances}

Viet Nam has no special EV policy or incentives and targets in place. It has registered with the United Nations Framework on Climate Change Convention a low-carbon bus Nationally Appropriate Mitigation Action which includes electric buses or e-buses. ${ }^{137}$ Apart from this, a large number of electric motorcycles (e-motorcycles) are plying the roads of Viet Nam, without being actively promoted by the government. Table 14 gives a snapshot of the potential environmental impact of EVs in Viet Nam.

Table 14: Environmental Impact of Electric Vehicles in Viet Nam

\begin{tabular}{|c|c|c|}
\hline Criteria & Situation & Comment \\
\hline $\begin{array}{l}\text { GHG impact } \\
\text { of EVs }\end{array}$ & Electricity grid factor $0.53 \mathrm{kgCO}_{2} \mathrm{e} / \mathrm{kWh}^{\mathrm{a}}$ & $\begin{array}{l}\text { The grid factor has remained constant in the last } 20 \text { years } \\
\text { with annual variations depending on rainfall. Based on } \\
\text { vehicle type, the grid factor results in emission reductions } \\
\text { by } 50 \%-70 \% \text { compared to fossil fuel vehicles. }\end{array}$ \\
\hline $\begin{array}{l}\text { Local pollution } \\
\text { impact of EVs }\end{array}$ & $\begin{array}{l}\text { Viet Nam has Euro } 4 \text { emission standards } \\
\text { and pollution costs of } \$ 42,000 \text { per ton of } \\
\mathrm{PM}_{2.5} \text { and } \$ 300 \text { per ton of } \mathrm{NO}_{x}, \mathrm{~b} \text { which is } \\
\text { the median level of DMCs of ADB. }\end{array}$ & $\begin{array}{l}\text { The impact of an EV on local pollution levels is relatively } \\
\text { low compared to a conventional new vehicle complying } \\
\text { with Euro } 4 \text {. }\end{array}$ \\
\hline
\end{tabular}

$\mathrm{ADB}=$ Asian Development Bank, DMC = developing member country, $\mathrm{EV}=$ electric vehicle, $\mathrm{GHG}=$ greenhouse gas, $\mathrm{kgCO}{ }_{2} \mathrm{e} / \mathrm{kWh}=$ kilogram of carbon dioxide equivalent per kilowatt-hour, $\mathrm{NO}_{\mathrm{x}}=$ nitrogen oxide, $\mathrm{PM}_{2.5}=$ particulate matter.

a Based on IEA data for 2015.

b \$2010; based on IMF. 2014. Getting Energy Prices Right. Washington, DC, Annex 4.2.

Source: Grütter Consulting.

137 UNFCCC. NAMAs seeking support for implementation. https://www4.unfccc.int/sites/publicnama/SitePages/Home.aspx (accessed 18 October 2018). 


\section{Ha Noi}

The metropolitan population of $\mathrm{Ha} \mathrm{Noi}$ is around 7.5 million with the city population being around 3.5 million. ${ }^{138}$ Based on household surveys in 2014, every second person has a motorcycle and 1 out of 10 people has an electric bike, i.e., in total around 4.6 million 2-wheelers are operating in the city of which around $16 \%$ or more than 700,000 are electric. ${ }^{139}$ In contrast, there are around 250,000 cars plying city roads..$^{140}$

\subsubsection{E-Motorcycles for $\mathrm{Ha} \mathrm{Noi}$}

As of 2014, Viet Nam had around 43 million registered motorcycles. ${ }^{141}$ The electric scooter or e-scooter market peaked in 2016 and then started declining due to customer issues on quality.

Gasoline motorcycles are four-stroke in $\mathrm{Ha}$ Noi and basically follow Euro 2 or Euro 3 standards with an engine displacement of $110 \mathrm{cc}$. Average urban fuel consumption is around 2.5 liters per 100 kilometers $(\mathrm{km})$ and an average annual mileage of $4,100 \mathrm{~km} \cdot{ }^{142}$ Good quality gasoline motorcycles cost $\$ 700-\$ 1,400$ while e-scooters are available at a lower price. However, even with comparable investment costs, good quality e-scooters cannot match gasoline units in power, speed, and driving range. Also, batteries need to be replaced around every 1-2 years and are lead-acid units which have high potential environmental impact. E-scooters are used primarily by students as they do not require a license, aside from the low purchase cost.

E-scooters basically have lead-acid batteries and are charged overnight. Battery swap facilities are not available. A Swiss-financed e-scooter and e-bike sharing program had limited success and basically folded down due to high prices and limited public transport routes for users. The system was based on few fixed points, i.e., not free floating and thus of limited convenience for users. Also, most students (which were the target group) already own an electric or conventional scooter.

Replacing all 4 million conventional motorcycles in $\mathrm{Ha}$ Noi with e-scooters would save around 800,000 tons of carbon dioxide equivalent $\left(\mathrm{tCO}_{2} \mathrm{e}\right)$, with the fleet using around 600,000 megawatthours (MWh) of electricity per year and charging basically at night, i.e., less than $0.5 \%$ of the 2015 electricity production of Viet Nam would be used.

\subsubsection{Conclusions}

E-scooters currently available have a limited market with students due to their characteristics, which make them less attractive even than more expensive gasoline-powered units. Vinfast, a local carmaker in Viet Nam, is planning on producing higher-powered e-motorcycles potentially with lithium-ion batteries. However, prices of such motorcycles are expected to be considerably higher than conventional scooters, while still having to replace batteries after 2-3 years and contend with customer issues such as driving range.

138 General Statistics Office (Government of Viet Nam). www.gso.gov.vn.

139 This includes e-motorbikes with a speed $>25 \mathrm{~km} / \mathrm{h}$ and electric bicycles with a power of less than $0.25 \mathrm{~kW}$.

140 Based on original World Bank survey results 2014; for a summative report, see World Bank, 2014b.

141 Viet Nam's National Traffic Safety Committee.

142 World Bank. 2014b. Motorcycle, Motor Scooter and Motorbike Ownership \& Use in Hanoi. Washington, DC, and original household survey data. 
The prospect of significantly reducing the number of gasoline motorcycles (and in turn, increasing the number of e-motorcycles) is limited unless the Government of Viet Nam provides for strong nonfinancial incentives favoring e-motorcycles or banning gasoline units. Currently, the government favors policies that promote use of public transport, with the objective of reducing the number of motorcycles, but not necessarily replacing them with electric units.

\subsection{Dhaka: Electric Rickshaws and Electric Pedicabs}

\subsubsection{Country and City Facts}

\section{Country Circumstances}

Bangladesh has no policies or incentives toward EVs, except its target for the electrification of services. However, there are an estimated 600,000 electric 3-wheelers operating in the country, of which around half are assumed to be battery-assisted pedal-rickshaws and the rest are electric rickshaws or e-rickshaws. ${ }^{143}$ Table 15 gives a snapshot of the potential environmental impact of EVs in Bangladesh.

\section{Dhaka}

As of 2011, Greater Dhaka had around 15 million inhabitant, which is expected to increase to 30 million by 2025. Greater Dhaka is the most densely populated city in the world. In 2014, GHG emissions in Dhaka due to passenger transport ranged from 2.3 million $\mathrm{tCO}_{2} \mathrm{e}$ tank-to-wheel (TTW) to 2.9 million $\mathrm{tCO}_{2} \mathrm{e}$ well-to-wheel (WTW), of which around 10\% are caused by motorized rickshaws which have a share of around 15\% of motorized trips. Under a business-as-usual scenario, GHG emissions of passenger transport in the city are expected to grow to 6 million- 8 million $\mathrm{tCO}_{2}$ e by $2030^{144}$ with compressed natural gas (CNG)-powered rickshaws accounting for more than $500,000 \mathrm{tCO}_{2}$ e emissions per annum. ${ }^{145}$

Table 15: Environmental Impact of Electric Vehicles in Bangladesh

\begin{tabular}{|c|c|c|}
\hline Criteria & Situation & Comment \\
\hline $\begin{array}{l}\text { GHG impact of } \\
\text { EVs }\end{array}$ & $\begin{array}{l}\text { Electricity grid factor } \\
0.64 \mathrm{kgCO}_{2} \mathrm{e} / \mathrm{kWh}^{a}\end{array}$ & $\begin{array}{l}\text { The grid factor has remained constant in the last } 20 \text { years with } \\
\text { small annual variations. Based on vehicle type, the grid factor } \\
\text { results in emission reductions by } 40 \%-60 \% \text { compared to } \\
\text { fossil fuel vehicles. }\end{array}$ \\
\hline $\begin{array}{l}\text { Local pollution } \\
\text { impact of EVs }\end{array}$ & $\begin{array}{l}\text { Bangladesh has Euro } 2 \text { emission } \\
\text { standards and pollution costs of } \\
\$ 52,000 \text { per ton of } \mathrm{PM}_{2.5} \text { and } \$ 370 \text { per } \\
\text { ton of } \mathrm{NO}_{\times}^{\mathrm{b}} \text { which is slightly above the } \\
\text { median level of DMCs of ADB. }\end{array}$ & $\begin{array}{l}\text { The impact of an EV on local pollution levels is high compared } \\
\text { to a conventional new vehicle due to the low vehicle emission } \\
\text { standard applied in the country and relatively high pollution } \\
\text { costs. }\end{array}$ \\
\hline
\end{tabular}

$\mathrm{ADB}=$ Asian Development Bank, $\mathrm{DMC}=$ developing member country, $\mathrm{EV}=$ electric vehicle, $\mathrm{GHG}=$ greenhouse gas, $\mathrm{kgCO} 2 \mathrm{e} / \mathrm{kWh}=$ kilogram of carbon dioxide equivalent per kilowatt-hour, $\mathrm{NO}_{\mathrm{x}}=$ nitrogen oxide, $\mathrm{PM}_{2.5}$ = particulate matter.

a Based on IEA data for 2015.

b \$2010; based on IMF. 2014. Getting Energy Prices Right. Washington, DC, Annex 4.2.

Source: Grütter Consulting.

143 Based on estimates of e-rickshaw association of Bangladesh, 2018.

144 Range lower to upper level based on TTW to WTW.

145 Grütter Consulting. 2016b. NAMA Urban Passenger Transport Dhaka, Bangladesh. 
Around 500,000 cycle rickshaws and around 50,000 CNG rickshaws operate in Dhaka. ${ }^{146}$ Currently, a large number of battery-assisted pedal rickshaws and e-rickshaws operate in the city. However, their usage has been restricted by the government due to concerns over design and safety of the vehicles, claims of low speed for main roads obstructing traffic, and especially due to illegal electric connections used by e-rickshaws creating stress on the grid, safety problems, and lack of payment. ${ }^{147}$ Currently, battery-assisted pedal rickshaws are confined to secondary roads while on main roads, only electric units operated by handicapped persons can be operated. ${ }^{148}$ Standard e-rickshaws can only be operated in confined areas while CNG units can be operated all over the city.

\subsubsection{Electric Rickshaws and Electric Pedicabs for Dhaka}

Battery-assisted pedal rickshaws are popular in Dhaka although they can only be operated with restrictions on secondary roads. Battery-assisted pedal rickshaws are much faster than manual rickshaws and help save the pullers from a lot of physical stress. Versions used are simple rickshaws with a 500-watt engine and lead-acid batteries with a life span of 6 months to 1 year. They are not only faster than manual units, but also result in higher income for drivers who are able to put in more trips per day.

Higher-powered e-rickshaws can accommodate up to eight passengers and are only allowed in confined areas on secondary streets. In general, these use two battery sets of lead-acid batteries with a life span of 1-1.5 years. Drivers prefer the electric units compared to CNG-powered units as they can carry more passengers, have a lower initial purchase cost, and also lower operational costs. Major drawbacks are regular battery replacement and limited usage.

Obviously, e-rickshaws are financially attractive although batteries have to be replaced every year, i.e., if vehicles are used for more than 5-6 years, electric units tend to be more expensive than CNG units. While they do use electricity, the cost is not necessarily paid to the power company, but to third parties that often provide power through illegal connections. E-rickshaws would be used even more in the city if they were allowed to operate comparable to pedal-rickshaws or CNG units.

\section{Table 16: Cost of Rickshaws in Dhaka}

$(\$)$

\begin{tabular}{|c|c|c|c|c|}
\hline Parameter & $\begin{array}{c}\text { Manual } \\
\text { Rickshaw }\end{array}$ & $\begin{array}{c}\text { Battery-Assisted } \\
\text { Pedal Rickshaw }\end{array}$ & Electric Rickshaw & CNG Rickshaw \\
\hline Features & $\begin{array}{l}\text { Manually } \\
\text { powered for } \\
\text { two passengers }\end{array}$ & $\begin{array}{l}\text { For two passengers, lead- } \\
\text { acid battery with } 6 \text { months } \\
\text { to } 1 \text { year life span, battery } \\
\text { replacement costs around } \\
\$ 200, \$ 0.60 \text { electricity cost } \\
\text { per day }\end{array}$ & $\begin{array}{l}\text { For } 6-8 \text { passengers; lead-acid } \\
\text { battery with 1-1.5 years; can drive } \\
100-120 \mathrm{~km} \text { per day using } \$ 1.50 \\
\text { of electricity per day; battery } \\
\text { replacement cost around } \$ 600 \text {; } \\
\text { electricity consumption of around } \\
0.13 \mathrm{kWh} / \mathrm{km}\end{array}$ & $\begin{array}{l}\text { For 2-3 passengers; } \\
\text { same mileage as electric } \\
\text { rickshaw; very high price } \\
\text { due to high tax levied } \\
\text { on CNG-powered } \\
\text { rickshaws }\end{array}$ \\
\hline Cost & $\$ 300$ & $\$ 600$ & $\$ 1,800$ & $\$ 4,500$ \\
\hline
\end{tabular}

$\mathrm{CNG}=$ compressed natural gas, $\mathrm{EV}=$ electric vehicle, $\mathrm{GHG}=$ greenhouse gas, $\mathrm{km}=$ kilometer, $\mathrm{kWh} / \mathrm{km}=$ kilowatt-hour per kilometer. Source: Grütter Consulting.

146 ADB, 2013 for number of pedal rickshaws and number of CNG rickshaws calculated by Grütter Consulting based on data of annual vkm and average daily distance driven of units.

147 Financial Express, Vol. 20, No. 336, 31 March 2012.

148 The same does not hold true for conventional pedal-rickshaws. 
More modern units would be e-pedicabs (see chapter on e-rickshaws in Nepal) and the usage of e-rickshaws with lithium-ion batteries (see next chapter on e-rickshaws in Udaipur) with higher power, less battery replacement requirements, and less environmental problems. E-pedicabs, however, carry a significantly higher price tag, almost triple the cost of e-rickshaws with lithium-ion batteries and double the cost of current lead-acid powered units.

Modern electric 3-wheelers have a large potential for GHG emissions reduction in Dhaka as substitutes for CNG units and by being used for last-mile trips, increasingly becoming motorized as means of transport. CNG rickshaws currently emit around 320,000 tons of GHG emissions per annum (WTW) in Dhaka, as well as noise and high $\mathrm{NO}_{x}$ emissions. Using electricity from the grid, replacing all CNG rickshaws and instead using e-rickshaws would result in a reduction of around $180,000 \mathrm{tCO}_{2}$ e per annum; if electricity would be provided by renewable sources, reductions of $320,000 \mathrm{tCO}_{2}$ e per annum could be achieved.

\subsubsection{Conclusions}

A recent top-level stakeholder meeting to address e-rickshaws convened by the Prime Minister of Bangladesh required e-rickshaws to get officially registered to ensure public safety and sought to resolve the issue of charging and electricity pilferage. Political interest to promote e-rickshaws and substitute pedal-rickshaws and CNG units is strong, but linked to a program which provides for safe designs of units, legal registration of units, and solution to the charging problem. A program addressing these issues (e.g., using e-rickshaws with battery swap systems and charging at swap stations with EV systems) would be an attractive option for Dhaka. It would not only have a significant impact on GHG reduction, but would also improve the livelihood of rickshaw drivers. It is important, however, that new e-rickshaw models are introduced which comply with safety standards, are based on lithium-ion batteries, and offered as a packaged solution with charging infrastructure powered by renewable energy sources to ensure political support.

\subsection{Udaipur: Electric Rickshaws}

\subsubsection{Country and City Circumstances}

\section{National Circumstances}

In 2013, India unveiled the National Electric Mobility Mission Plan 2020 with the mission to make India a leader in the EV sector, targeting 6 million to 7 million EVs on the road by 2020, including 400,000 passenger cars. The Faster Adoption and Manufacturing of Electric-Vehicles program ${ }^{149}$ was launched for the period 2015-2017, extended until April 2018 and later on until September 2018. ${ }^{150}$ But these short extension periods result in a lack of continuity and future clarity about financial incentives for EVs. As of mid-2018, financial incentives for EVs reached a maximum of $\$ 400$ for scooters and motorcycles, $\$ 900$ for 3 -wheelers, $\$ 2,000$ for cars, and up to $\$ 100,000$ for buses. ${ }^{151}$ As of the same period, some 200,000 hybrid and EVs were sold under this scheme, with the overwhelming majority of

\footnotetext{
149 Includes also hybrids.

150 FAME-India (National Mission on Electric Mobility). https://www.fame-india.gov.in/.

151 S. Mukherjee. 2018. Government extends FAME India scheme for third time. The Economic Times. 14 April. https:// economictimes.indiatimes.com/industry/auto/auto-news/government-extends-fame-india-scheme-for-third-time/ articleshow/63759900.cms.
} 
Table 17: Environmental Impact of Electric Vehicles in India

\begin{tabular}{|c|c|c|}
\hline Criteria & Situation & Comment \\
\hline $\begin{array}{l}\text { GHG impact of } \\
\text { EVs }\end{array}$ & Electricity grid factor $0.82 \mathrm{kgCO}_{2} \mathrm{e} / \mathrm{kWh}^{\mathrm{a}}$ & $\begin{array}{l}\text { EVs with this grid factor reduce by } 10 \%-50 \% \text { of GHG } \\
\text { emissions, i.e., greening of the grid is important. The grid } \\
\text { factor has improved on average annually by } 1.5 \% \text { over the } \\
\text { last } 2 \text { decades; however, at this rate, India's grid will still be } \\
\text { highly carbon intensive over the next } 2 \text { decades. }\end{array}$ \\
\hline $\begin{array}{l}\text { Local pollution } \\
\text { impact of EVs }\end{array}$ & $\begin{array}{l}\text { India has the vehicle emission standard } \\
\text { BS IV (equivalent to Euro } 4 \text { ) and pollution } \\
\text { costs of } \$ 32,000 \text { per ton of } \mathrm{PM}_{2.5} \text { and } \\
\$ 230 \text { per ton of } \mathrm{NO}_{x}{ }^{d} \text { which is below the } \\
\text { median level of DMCs of ADB. }\end{array}$ & $\begin{array}{l}\text { The impact of an EV on local pollution levels is relatively } \\
\text { low compared to a conventional new vehicle complying } \\
\text { with BS IV (equivalent to Euro 4). }\end{array}$ \\
\hline
\end{tabular}

$\mathrm{ADB}=$ Asian Development Bank, DMC = developing member country, EV = electric vehicle, $\mathrm{GHG}=$ greenhouse gas, $\mathrm{kgCO} \mathrm{e}_{2} / \mathrm{kWh}=$ kilogram of carbon dioxide equivalent per kilowatt-hour, $\mathrm{NO}_{x}=$ nitrogen oxide, $\mathrm{PM}_{2.5}=$ particulate matter.

a CEA (2017), $\mathrm{CO}_{2}$ Baseline Database Vs. 12; based on total net electricity generation and total $\mathrm{CO}_{2}$ emissions.

b WTW approach; lower value for buses and upper value for motorcycles.

c Based on IEA data.

d \$2010; based on IMF, 2014, Annex 4.2.

Source: Grütter Consulting.

EVs being 2-wheelers and less than 10,000 are electric cars, ${ }^{152}$ which was far off the target of 6 million to 7 million units.

In 2016, the Prime Minister of India announced that all vehicles sold by 2030 will be electric. ${ }^{153}$ This target has been revised recently to about $30 \%$ of total vehicles. ${ }^{154}$ The Government of India also decided to go beyond a national EV policy and pursue action plans. Manufacturers voiced concerns over the lack of a clear policy road map, including a policy on charging infrastructure. While the national policy lacks clarity, various progressive states such as Karnataka have been rolling out EV guidelines and policies. ${ }^{155}$

Table 17 gives a snapshot of the potential environmental impact of EVs in India.

\section{Udaipur}

Based on the 2011 census, Udaipur ${ }^{156}$ has a population of around 450,000. 157 Around 10,000 different sized and basically diesel rickshaws account for a large part of public transport due to lack of a robust bus-based public transport system. In 2013, GHG transport emissions (WTW, including black carbon) in the city were around $120,000 \mathrm{tCO}_{2}$ e of which rickshaws represent $24 \%$. By 2030 , under a businessas-usual scenario, GHG emissions are expected to increase to around 380,000 $\mathrm{tCO}_{2} \mathrm{e}$. The city also suffers from increased pollution levels due to diesel vehicles.

152 The majority of cars sold under the Faster Adoption and Manufacture of (Hybrid and) Electric Vehicles) scheme or FAME are hybrids.

153 S. Edelstein. 2016. India's ambitious goal: all electric vehicles on roads by 2030. Green Car Reports. 31 March. https://www. greencarreports.com/news/1103162_indias-ambitious-goal-all-electric-vehicles-on-roads-by-2030.

154 K. Sharma. 2018. India scaling back electric vehicle ambitions. Nikkei Asian Review. 8 March. https://asia.nikkei.com/ Economy/India-starts-argument-over-realistic-EV-targets-for-2030.

155 S. Mukherjee. 2018. How The Govt's Flip-Flop On Policy Is Slowing Down EV Adoption In India. Inc42. 30 May. https://inc42. com/features/how-the-govts-flip-flop-on-policy-is-slowing-down-ev-adoption-in-india/.

156 Derived basically from Grütter Consulting. 2016a. GHG Transport Inventory and Mitigation Options Udaipur.

157 Census 2011. https://www.census2011.co.in/. 


\subsubsection{Electric Rickshaws for Udaipur}

The Udaipur Municipal Corporation plans to transform its rickshaw fleet by introducing e-rickshaws and restricting the growth of diesel- and gasoline-based units. With assistance by the Capacities project funded by the Swiss Development Cooperation, a pilot project with 18 e-rickshaws from which the following data is derived.

Low-powered e-rickshaws with lead-acid batteries, used in most Indian cities, have significant disadvantages in carrying capacity, power, and speed, especially in hilly conditions such as in Udaipur. Higher-powered versions with lithium-ion batteries are available, albeit at higher cost. Lithium-ion batteries create less environmental problems and hazards with recycling, have a longer life span, and can be charged faster. Technical and environmental advantages therefore clearly point toward usage of e-rickshaws with lithium-ion batteries. Table 18 compares usage of diesel and e-rickshaws in Udaipur.

Due to the high grid factor, the GHG reduction (WTW) is only $12 \%$ of e-rickshaws compared to diesel units, i.e., alternative sources of electricity production are important. The GHG impact can be significantly enhanced by using solar charging stations, a technology which can be combined well with e-rickshaws. This would increase the annual GHG reduction of a fleet of e-rickshaws in Udaipur from $850 \mathrm{tCO}_{2} \mathrm{e}$ to nearly $6,000 \mathrm{tCO}_{2}$, i.e., around $5 \%$ of the annual $\mathrm{GHG}$ emissions from the transport sector in Udaipur could be reduced.

Annual electricity required is less than 8,000 MWh which is marginal for the city of Udaipur. However, there are concerns over increased peak-load which could be resolved through solar charging systems.

In financial terms, e-rickshaws are excluded from subsidies making them slightly more expensive than diesel units; including the current government subsidy would make e-rickshaws at par or even slightly

Table 18: Diesel versus Electric Rickshaws in Udaipur

\begin{tabular}{|c|c|c|}
\hline Parameter & Diesel Rickshaw & E-Rickshaw ${ }^{\mathrm{a}}$ \\
\hline GHG emissions per unit per annum & $\begin{array}{l}\text { TTW: } 0.97 \mathrm{tCO}_{2} \\
\text { WTW: } 1.19 \mathrm{tCO}_{2}\end{array}$ & $\begin{array}{l}\text { TTW: } 0 \mathrm{tCO}_{2} \\
\text { WTW: } 1.05 \mathrm{tCO}_{2}\end{array}$ \\
\hline GHG reductions per annum fleet: 6,000 units & - & $\begin{array}{l}\text { TTW: } 5,800 \mathrm{tCO}_{2} \\
\text { WTW: } 850 \mathrm{tCO}_{2}\end{array}$ \\
\hline CAPEX per unit & $\$ 3,400$ & $\begin{array}{l}\$ 4,900 \text { including charger and two times } \\
\text { battery replacement }\end{array}$ \\
\hline OPEX per unit annually ${ }^{c}$ & $\$ 440$ & $\$ 250$ \\
\hline Subsidy, Government of India & - & $\$ 650$ \\
\hline Total Cost of Ownership per kilometer & $\$ 0.63 / \mathrm{km}$ & $\begin{array}{l}\$ 0.61 \text { per kilometer with subsidy } \\
\$ 0.68 \text { per kilometer excluding subsidy }\end{array}$ \\
\hline
\end{tabular}

CAPEX = capital expenditure, $\mathrm{GHG}=$ greenhouse gas, OPEX = operational expenditure, TTW = tank-to-wheel, $\mathrm{tCO}_{2}=$ ton of carbon dioxide, WTW = well-to-wheel.

a Li-ion unit; 6-seater; 1,500-watt engine.

b Battery replacement cost assumed at $50 \%$ of current average price; no discounting; CAPEX of vehicle $\$ 3,500$, i.e., comparable to diesel unit; charger cost $\$ 150$; battery cost as of 2018 including recycling charge $\$ 1,290$.

c Includes energy and maintenance.

Source: Grütter Consulting, based on data of pilot study with data from Capacities. 2018. E-Rickshaw Pilot Assessment for Udaipur, Rajasthan, based on 6,000 e-rickshaws, calculated with lithium-ion units (data details, see Appendix). 
less expensive than diesel units. ${ }^{158}$ E-rickshaws, however, require battery replacement every 2 years, i.e., significant CAPEX investments which require financial planning by rickshaw owners or a system based on leased batteries.

The major barriers to widespread adoption of e-rickshaws include:

- Grid capacity is limited and authorities are afraid of additional peak load. This could be resolved through smart charging and battery swap offers, or charging with solar systems without putting an increased load on the grid.

- The driving range of current models is around $50 \mathrm{~km}$ without charge, which potentially limits the income of e-rickshaw drivers. This can be resolved by battery swap systems and/or with fast chargers to reduce battery charging time (currently at 4 hours using 1 kilowatt chargers).

- Reliability of lithium-ion rickshaws is still low with full discharges experienced frequently. This is because majority of e-rickshaws in India are still using lead-acid batteries, with limited options and thereby experience with lithium-ion units.

- The low power of e-rickshaws results in slower driving speeds compared to conventional units. This contributes to the perception that slow-moving e-rickshaws increase traffic congestion. Higher-powered e-rickshaws can help overcome this problem, but requires higher costs (increased vehicle and battery cost plus increased electricity usage).

- While subsidies are theoretically available, drivers in Delhi, for example, report that it is very difficult to access the subsidy fund and only $1 \%$ of the drivers actually obtained the incentive..$^{159}$

\subsubsection{Conclusions}

E-rickshaws used currently in India are basically low-cost, low-power lead-acid units with a short battery life span of 6 months to 1 year, with significant disadvantages in speed, power, load capacity, and driving range when compared to conventional units, while also creating potential health and environmental hazards with battery recycling. These are financially attractive enough to be taken up without further incentives by some rickshaw owners despite the technical disadvantages and environmental risks.

Higher-powered lithium-ion e-rickshaws, while not yet popular in India, can become an alternative and fare better against conventional rickshaws in power and load capacity, and also less environmental hazards concerning battery recycling. However, to have a significant GHG impact, these should be charged through renewable local energy sources, e.g., off-grid solar photovoltaic systems. To enhance driving range, battery swap systems or higher-powered fast chargers will be required. Also, the quality and after-sales service of these lithium-ion e-rickshaws need to be improved. In terms of costs, these can become a viable alternative with slightly higher total cost of ownership than conventional units however, the charging structure required, including potentially a battery swapping scheme as well as high battery replacement costs and higher initial CAPEX, would very much favor a fleet approach based on, for example, leasing vehicles to owners. This would also allow for financing with lower interest rates as well as facilitate access to subsidy schemes for individual rickshaw owners. Aggregators could also help enforce improved after-sales service and higher quality products due to being high-volume buyers, who can push manufacturers toward providing high-quality units.

\footnotetext{
158 Based on total cost of ownership.

159 Capacities. 2018b. Assessment of E-Rickshaw Operations in Delhi.
} 
An interesting approach with a significant environmental and social potential could be to work with aggregators who lease lithium-ion high-quality rickshaws, put up a charging network based on solar photovoltaic systems combined with battery swap systems, charging their clients a fixed daily fee plus a battery swap fee. Aggregators would also realize the financial structuring and collect subsidies as well as other possible incentives. Such as system can be financially sustainable if put up sufficiently large in size from the start to ensure a good charging network and a financially sustainable relation between e-rickshaws and charging facilities.

\subsection{Manila: Electric Jeepneys}

\subsubsection{Country and City Circumstances}

\section{Country Circumstances}

EVs pay no excise tax. Some nonfinancial incentives are given for EVs by local government such as preferential franchise and/or route for e-trikes, exemption from number coding scheme, and longer franchise years. The following table gives a snapshot of the potential environmental impact of EVs in the Philippines.

\section{Manila}

Metro Manila is estimated to have a population of around 12 million inhabitants. ${ }^{160}$ In 2013 , the Department of Energy, with assistance from ADB, started planning for an e-tricycle or e-trike program (consisting of 100,000 units) intended to replace gasoline-powered tricycles; in 2017, it was downscaled to 3,000 units due to concerns over pricing and design flaws. ${ }^{161}$ The e-trikes have a 5-kilowatt electric motor with a 3.2 kilowatt-hour lithium-ion battery and can carry up to five passengers and each costs $\$ 4,000-\$ 9,000.162$

Table 19: Environmental Impact of Electric Vehicles in the Philippines

\begin{tabular}{|c|c|c|}
\hline Criteria & Situation & Comment \\
\hline $\begin{array}{l}\text { GHG impact of } \\
\text { EVs }\end{array}$ & $\begin{array}{l}\text { Electricity grid factor at } \\
0.68 \mathrm{kgCO}_{2} \mathrm{e} / \mathrm{kWh}^{\mathrm{a}}\end{array}$ & $\begin{array}{l}\text { The grid factor has remained constant in the last } 20 \text { years with } \\
\text { small annual variations. Based on vehicle type, the grid factor } \\
\text { results in emission reductions by } 40 \%-60 \% \text { compared to } \\
\text { fossil fuel vehicles. }\end{array}$ \\
\hline $\begin{array}{l}\text { Local pollution } \\
\text { impact of EVs }\end{array}$ & $\begin{array}{l}\text { The Philippines has Euro } 4 \text { emission } \\
\text { standards and pollution costs of } \\
\$ 39,000 \text { per ton of } \mathrm{PM}_{2.5} \text { and } \$ 290 \text { per } \\
\text { ton of } \mathrm{NO}_{\times}^{\mathrm{b}} \text { which is below the median } \\
\text { level of DMCs of ADB. }\end{array}$ & $\begin{array}{l}\text { The impact of an EV on local pollution levels is limited } \\
\text { compared to a conventional new vehicle reflected due to the } \\
\text { current vehicle emission standard Euro } 4 \text { and relatively low } \\
\text { pollution costs. }\end{array}$ \\
\hline
\end{tabular}

$\mathrm{ADB}=$ Asian Development Bank, DMC = developing member country, $\mathrm{EV}=$ electric vehicle, $\mathrm{GHG}=$ greenhouse gas, $\mathrm{kgCO}{ }_{2} \mathrm{e} / \mathrm{kWh}=$ kilogram of carbon dioxide equivalent per kilowatt-hour, $\mathrm{NO}_{\mathrm{x}}=$ nitrogen oxide, $\mathrm{PM}_{2.5}=$ particulate matter.

a Based on IEA data for 2015.

b \$2010; based on IMF. 2014. Getting Energy Prices Right. Washington, DC, Annex 4.2.

Source: Grütter Consulting.

160 World Population Review. Manila Population 2019. http://worldpopulationreview.com/world-cities/manila-population/.

161 Department of Energy. 2017. Scaled-Down E-Trike Project to Push Through: DOE. https://www.doe.gov.ph/press-releases/ scaled-down-e-trike-project-push-through-doe.

162 Garcia, A.M. Department of Energy. Alternative Fuels Vehicle and Technology, presentation at Energy Investment Forum and Stakeholders Conference on 3 October 2017. 


\subsubsection{Electric Jeepneys in Manila}

The private company QEV, ${ }^{163}$ in partnership with Filipino entrepeneur Endika Aboitiz, is manufacturing with three local companies e-jeepneys based on Spanish EV technology. Vehicles are either new units or diesel units converted to e-jeepneys and are equipped with $60 \mathrm{kWh}$ battery set. Fifty units were deployed in September 2018 on a $35 \mathrm{~km}$ jeepney route with fast charging, with $30 \mathrm{~kW}$ applied every second round. QEV puts up the charging infrastructure, located at gas stations and malls, and is open for all types of customers. The local partner also owns an electricity distribution company and the business model is therefore structured around chargers and supplying electricity to vehicles which use these chargers.

\subsubsection{Conclusions}

Partnering with a local electricity service provider to build an open charging infrastructure, while also creating demand through introducing $\mathrm{EVs}$, is a promising approach. A critical factor will be how the costs of e-jeepneys can be made comparable to conventional units, also in light of relatively high electricity costs in the Philippines. The experience of e-trikes in the Philippines shows that design failures and high costs of EVs are barriers to mass adoption. At the same time, the GHG impact of EVs in the Philippines is limited due to the country's high grid factor.

\subsection{Fiji: Electric Cars and Renewable Grid Integration}

\subsubsection{Country Circumstances}

In 2015, the population of Fiji was close to 900,000 inhabitants $^{164}$ and the number of vehicles was around 100,000 , of which around 2,000 are buses (minibuses as well as larger units); and around 18,000 are cargo or goods vehicles, which include light- and heavy-duty vehicles such as vans, pick-ups, trucks, and special purpose vehicles. ${ }^{165}$ Figure 49 shows the vehicle distribution in Fiji.

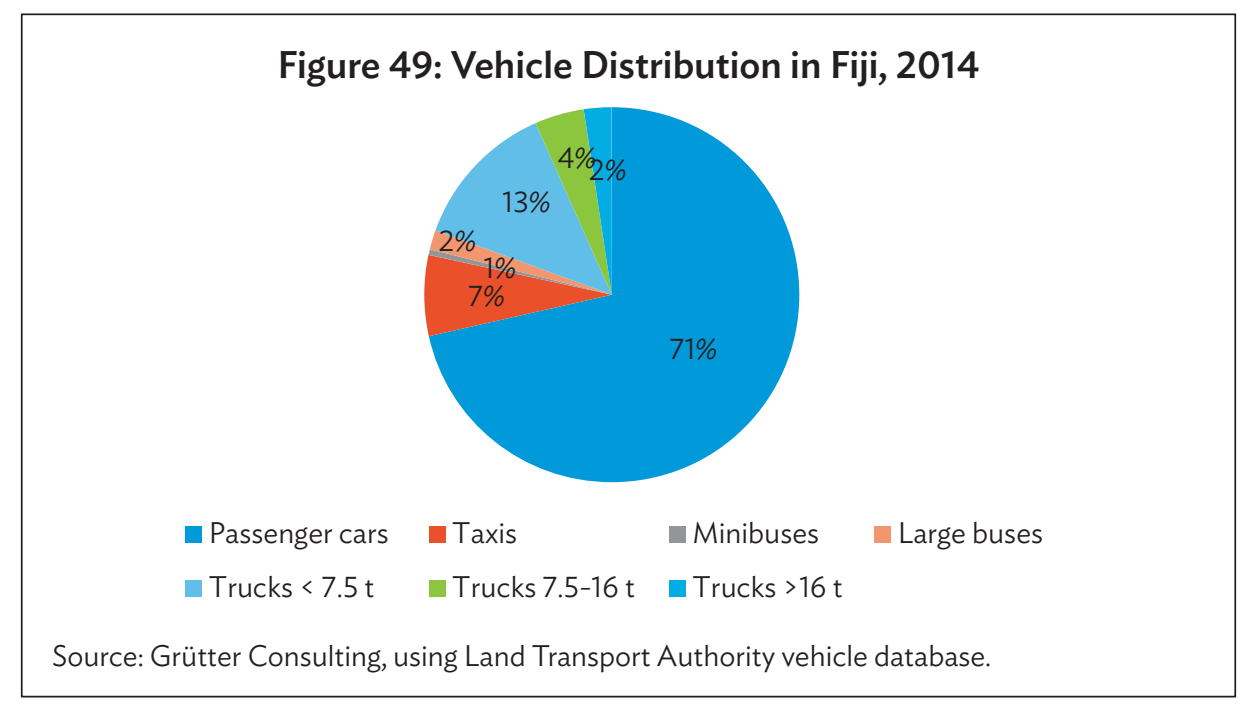

163 QEV E-Mobility. News. http://qevi.com/news/.

164 World Bank. Population estimates and projections. https://databank.worldbank.org/data/source/population-estimatesand-projections (accessed 18 October 2018).

165 Land Transport Authority (LTA). 
Table 20: Greenhouse Gas Emissions in Fiji, 2014

\begin{tabular}{lrc}
\multicolumn{3}{c}{$\left(\mathrm{tCO}_{2}\right)$} \\
\hline Vehicle Category & Value & Share \\
\hline Passenger cars & 177,388 & $28 \%$ \\
Taxis & 82,616 & $13 \%$ \\
Goods vehicles & 284,222 & $45 \%$ \\
Buses & 91,747 & $14 \%$ \\
Total & 635,972 & \\
\hline $\mathrm{tCO}_{2}=$ ton of carbon dioxide. & & \\
Source: Grütter Consulting. & &
\end{tabular}

Hybrid cars have surged a lot in the past few years due to tax incentives. This has encouraged the importation of second-hand vehicles. The Nationally Determined Contribution (NDC), as well as various national strategy documents, wants to foster adoption of EVs, and EV targets are under discussion for the NDC implementation plan to 2030. Plans to stop importation of conventional fossil fuel vehicles are under discussion with different targets ranging from 2025 to 2050 . The focus is initially on electrifying public transport buses followed by other vehicle categories.

In 2014, GHG emissions by the land transport sector are around 640,000 tCO . GHG emissions are dominated by the goods sector with $45 \%$ of emissions, followed by passenger cars with $28 \%$, and buses as well as taxis with $13 \%-14 \%$ each.

Fiji is in the process of developing a Low-Emission Development Strategy with different scenarios, ranging from an unconditional business-as-usual scenario based on the NDC target of reducing 10\% of GHG emissions to a high ambition scenario which strives for zero-emissions by the road transport sector by 2050 (Figure 50).

For all scenarios, the most important mitigation action is EVs contributing by $50 \%-70 \%$ of total GHG mitigation. For each scenario, detailed 5-year EV penetration targets have been established. The highest ambition scenario has $100 \%$ of new vehicles imported to Fiji being electric by 2030, while the other scenarios have lower penetration targets at later periods. Buses, urban trucks, and taxis have in all scenarios earlier penetration rates than cars and large trucks.

The grid factor of Fiji is currently $0.37 \mathrm{kgCO}_{2} \mathrm{e} / \mathrm{kWh}^{166} \mathrm{Fiji}$, however, intends to move to virtually $100 \%$ renewable even with the significantly increased electricity demand due to the EV promotion strategy (see next section).

\subsubsection{Electric Cars and Buses for Fiji}

Figure 51 shows the number of electric cars and buses in Fiji projected up to 2050 based on the lowest and the highest ambition scenario.

166 Based on FEA annual report 2015, p. 23 (electricity generation); fuel used, p. 24; and using average NCV and EF per fuel type of IPCC, 1996. 

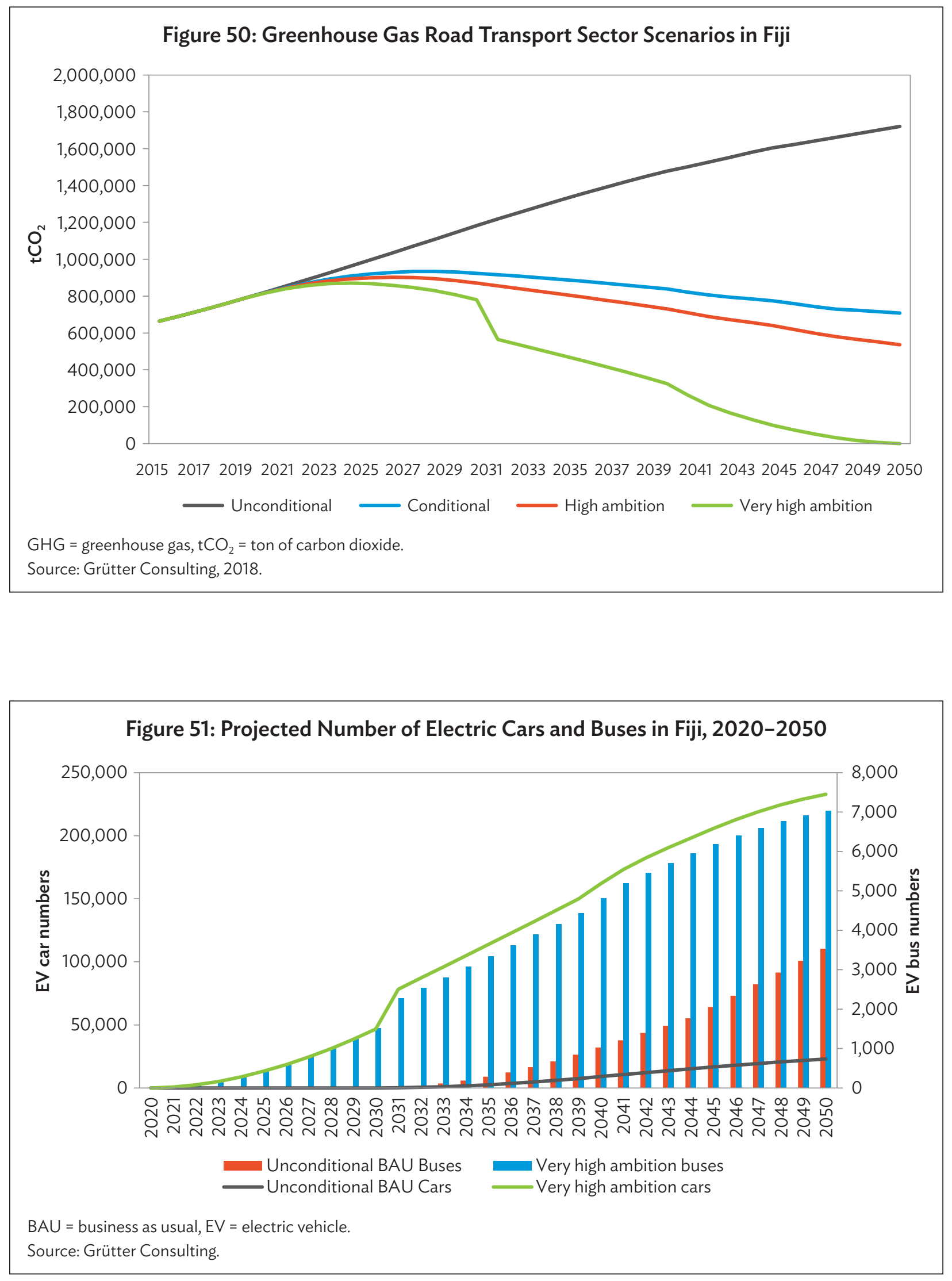


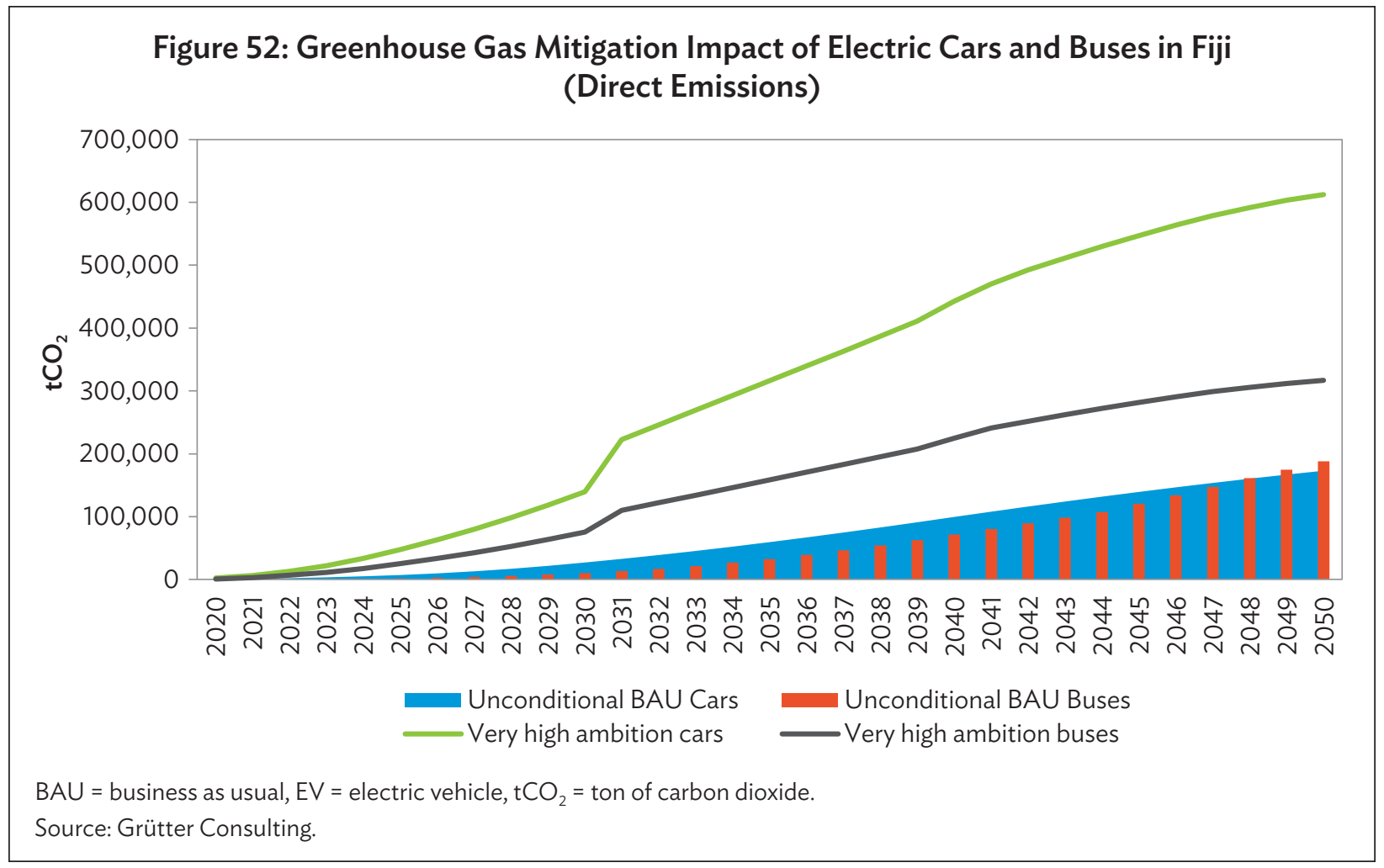

More than 200,000 electric cars and 3,000-7,000 e-buses (under a very high ambition scenario) are expected to operate in Fiji by $2050 .{ }^{167}$ Numbers increase gradually due to relatively high average vehicle usage and thus low vehicle replacement rates. The share of electric cars would be between 10\%-100\% (ranging from lowest to highest scenario) and e-buses would be $50 \%-100 \%$.

The direct GHG impact of EVs is shown in Figure 52 (based only on cars and buses while the Low-Emission Development Strategy also includes trucks and taxis).

Annual emission reductions of 200,000-600,000 $\mathrm{tCO}_{2}$ for electric cars for the low ambition scenario and 200,000-300,000 $\mathrm{tCO}_{2}$ for e-buses for the highest ambition scenario can be achieved by 2050 . This is a reduction of $35 \%-100 \%$ of the GHG emissions of these vehicle categories and represents a very significant reduction of overall GHG emissions in Fiji (total transport emissions are reduced by 15\%-40\%). These reductions are based on direct emissions only and do not include emissions of Fiji's electricity grid. Projections to 2050 show a grid factor of $0-0.4 \mathrm{kgCO}_{2} \mathrm{e} / \mathrm{kWh}$ (comparable to today). The higher grid factor would result in GHG reductions being 25\%-35\% lower.

The impact of additional electricity demand from the EV strategy is considerable. Figure 53 shows the electricity usage from mobility relative to other users.

167 Vehicle numbers increase strongly as Fiji expects an average annual gross domestic product growth rate in real terms of $4.5 \%$ until 2050 and vehicle-km have been projected based on an elasticity of 1 for passenger vehicle-kilometer ( $\mathrm{vkm}$ ) and for ton-kilometer (tkm) based on https://www.fhwa.dot.gov/policy/otps/pubs/vmt_gdp/index.cfm\#sect3 for passenger vkm and OECD for freight tkm elasticity. 
Figure 53: Projected Electricity Usage in Fiji per Sector (Very High Ambition Scenario) (GWh'000)

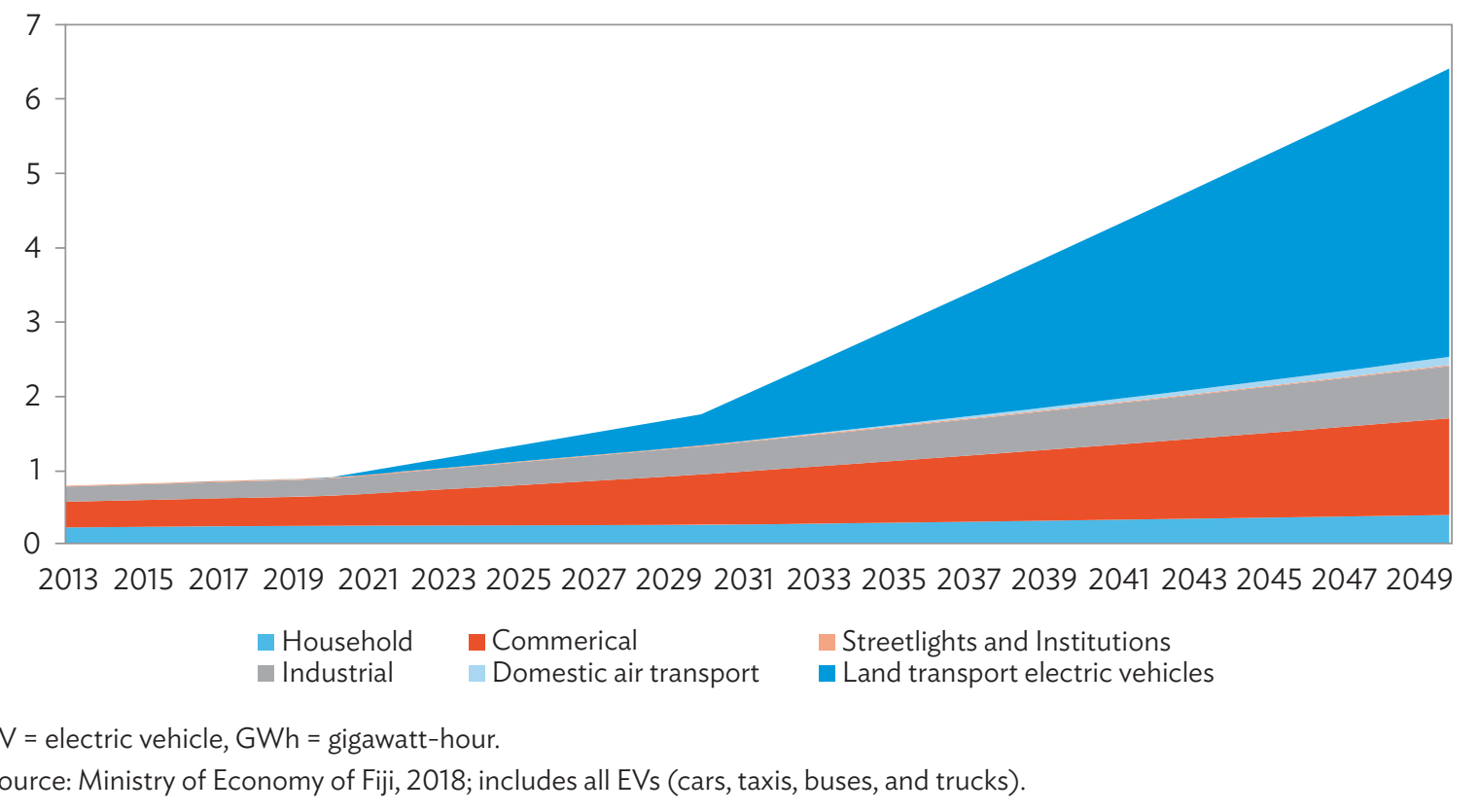

Demand from EVs by 2050 would surpass today's electricity supply by far. Electricity demand alone by cars would be 50-370 gigawatt-hours (GWh) and by buses 220-380 GWh in 2050, while total electricity production of Fiji in 2015 was $880 \mathrm{GWh}$. The strategy to run 100\% EVs will have a significant additional demand on the grid from 2030-2035 or onward. If EVs are not run with renewables, this will result in GHG emissions from electricity production itself, i.e., the grid needs to be made dependent on renewable energy sources as possible while the demand from EVs increases massively. The reason why the impact is so large in Fiji compared to other countries is low electricity production and consumption base, including very limited industrial and household demand. Large-scale EV promotion will have a significant impact on electricity and peak demand in small island states such as Fiji.

Running $100 \%$ EVs not only stresses the grid in electricity production, but also in power demand (Figure 54).

By 2050 , around $70 \%$ of the expected peak power demand would be caused by EVs. Currently, Fiji only operates with one fixed tariff plus a power charge. To reduce additional power demand and peaks, the pricing policy will require revision with price differentiation between times of the day (depending on the grid established, e.g., if wind power plays an important role, night tariffs would need to be reduced) and for power demand.

EV charging can have a sizable impact on the loads applied to the grid at certain times and locations. Solutions being proposed for these problems involve controlled charging and smart charging. For fast charging, managing power demand is also likely to require the deployment of stationary storage at the 
Figure 54: Projected Peak Power Demand from Electric Mobility in Fiji (Scenario 4) (MW)

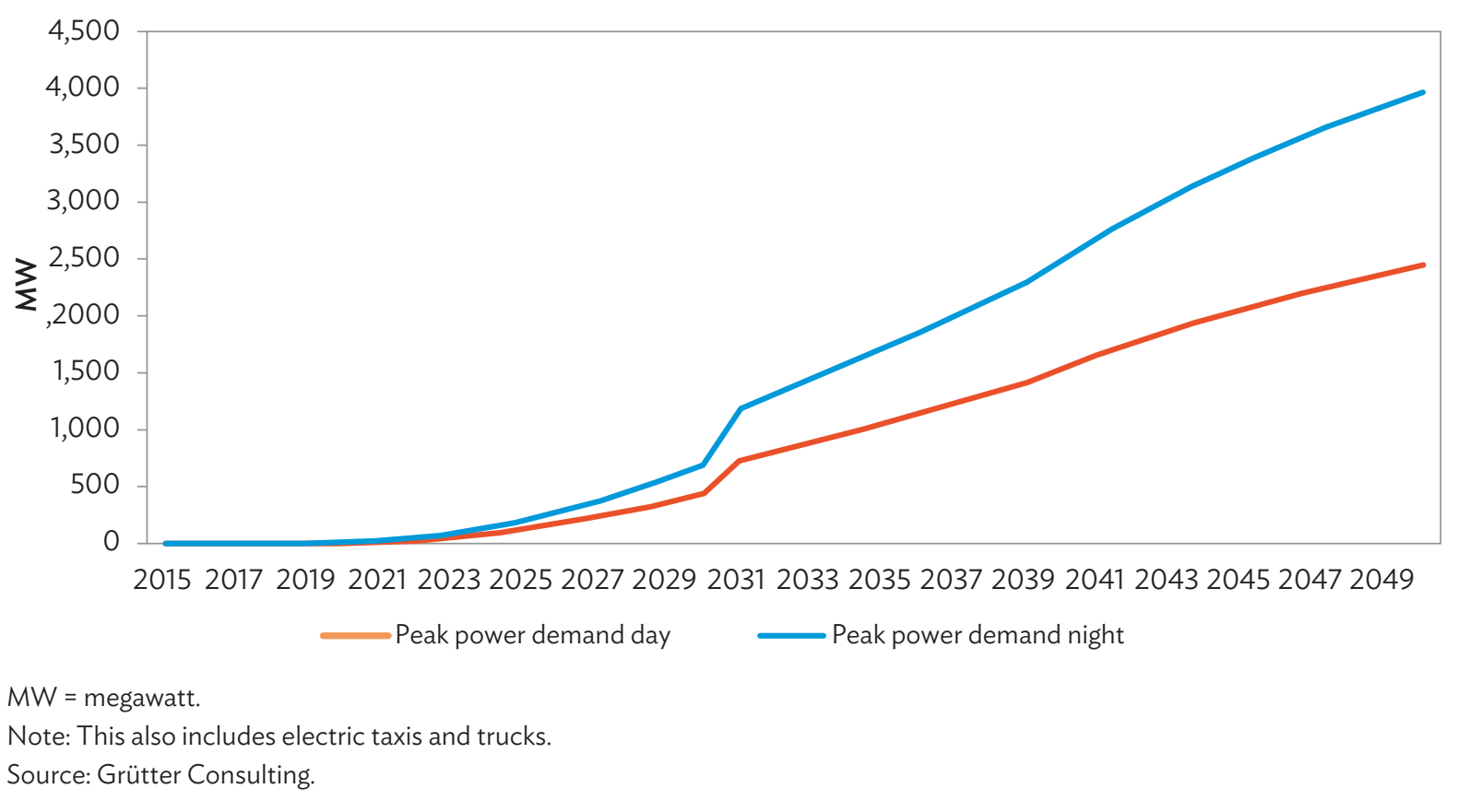

local level. ${ }^{168}$ Demand side management (DSM) is an instrument that can reduce the need for grid upgrades and additional generation capacity. It consists largely of optimizing the charging time to match power supply and demand, basically shifting charging to the night or midday (depending on the grid). ${ }^{169}$ Instruments used include dynamic tariffs that provide incentives to customers to charge EVs when optimal, assisted with smart charging applications which facilitate the work of customers by allowing them to take advantage of a dynamic tariff.

Used batteries of EVs can also provide for low-cost storage capacity, especially important in the case of Fiji which basically a production based on renewables. The effectiveness of DSM can be enhanced by bi-directional "vehicle-to-grid" (V2G) capabilities where power can flow from the grid to the vehicle, and vice versa. ${ }^{170}$ This could also be an attractive source of revenue for EV owners. The development of e-mobility and of a renewable electricity system can thus go hand-in-hand to reduce total costs considerably. EV fleets could play a role as distributed energy storage systems, thereby helping to increase the participation of renewables. Second-life batteries from EVs can also play an important role for storing the fluctuating supply of energy from renewables. ${ }^{171}$

168 IEA. 2017b. Global EV Outlook 2017. Paris.

169 High non-demanded power generation from wind generators during the night and solar PV at midday.

170 IEA. 2018b. Global EV Outlook 2018. Paris.

171 F. Lambert. 2018. Renault is trying to create a 'smart electric island with electric vehicles, V2G, and energy storage. electrek. 21 February. https://electrek.co/2018/02/21/renault-smart-electric-island-electric-vehicles-v2g-energy-storage/. 


\subsubsection{Conclusions}

As of today, Fiji basically imports used vehicles which have far lower cost than new units. In the case of the reduced tax on hybrid EVs, this resulted in a large influx of hybrid vehicles thus achieving its goal. The same is more difficult with EVs. Currently only very few second-hand EVs are available. While this will change in the future, used EVs will have at least partially depleted batteries, i.e., buyers will need to make costly investments in new battery sets while not having the advantages of a vehicle with a state-of-the art battery management system or charging option (i.e., in terms of charging power the vehicle supports). It will be difficult for second-hand EVs and worse, even for new EVs to compete with used conventional cars, i.e., a very large financial gap will exist between $\mathrm{EVs}$ and conventional units - this gap is smaller in countries where basically new and not second-hand vehicles are sold.

However, the political will to strongly foster adoption combined with a significant GHG impact show favorable conditions for promoting EVs in Fiji. Two areas are of interest and could be further explored:

- E-buses. The World Bank recently published a report on bus scrapping and replacement with low-carbon units. This could form a base for a more profound analysis of business strategies to promote EVs in the country including technical and financial analysis based on real-world figures.

- Electric passenger cars combined with a V2G approach while extending the renewable share of electricity generation. This approach could, for example, be piloted potentially in a small island such as Fiji with a limited number of vehicles to gain technical experience and determine the financial impact of such a strategy before promoting it on a wider scale. This would also be a critical input for many other small island developing states.

\subsection{Tbilisi: Electric Buses}

\subsubsection{Country and City Circumstances}

\section{National Circumstances}

Importation of electric cars is tax-free-however, import and excise taxes on conventional vehicles are very low, thus not resulting in an effective promotion of EVs. Under a grant agreement with the Government of Japan in 2017, 45 EVs and 55 PHEVs were purchased for the governmental car park. Table 21 gives a snapshot of the potential environmental impact of EVs in Georgia.

Tbilisi

Tbilisi has a population of around 1.1 million. ${ }^{172}$ Based on local reports, the city has significant air pollution problems. Second-hand vehicles are very popular. The city is currently in discussion to reduce parking fees for EVs (zero parking fee for EVs and reduced fee for hybrid EVs).

172 Based on population census of 2014; see www.geostat.ge. 
Table 21: Environmental Impact of Electric Vehicles in Georgia

\begin{tabular}{|c|c|c|}
\hline Criteria & Situation & Comment \\
\hline $\begin{array}{l}\text { GHG impact of } \\
\text { EVs }\end{array}$ & Electricity grid factor $0.13 \mathrm{kgCO}_{2} \mathrm{e} / \mathrm{kWh}^{\mathrm{a}}$ & $\begin{array}{l}\text { The grid factor of Georgia is very low, resulting in emission } \\
\text { reductions of around } 90 \% \text { compared to fossil fuel vehicles. }\end{array}$ \\
\hline $\begin{array}{l}\text { Local pollution } \\
\text { impact of EVs }\end{array}$ & $\begin{array}{l}\text { Georgia currently has no emission } \\
\text { standards for vehicles }{ }^{\mathrm{b}} \text { and pollution } \\
\text { costs of } \$ 77,000 \text { per ton of } \mathrm{PM}_{2.5} \text { and } \\
\$ 570 \text { per ton of } \mathrm{NO}_{x}{ }^{c} \text { which is below the } \\
\text { median level of DMCs of } \mathrm{ADB} \text {. }\end{array}$ & $\begin{array}{l}\text { The impact of an EV on local pollution levels is limited } \\
\text { compared to a conventional new vehicle as basically } \\
\text { Euro } 4 \text { vehicles are imported (for buses even Euro VI) and } \\
\text { pollution costs are relatively low. }\end{array}$ \\
\hline
\end{tabular}

$\mathrm{ADB}=$ Asian Development Bank, $\mathrm{DMC}=$ developing member country, $\mathrm{EV}=$ electric vehicle, $\mathrm{GHG}=$ greenhouse gas, $\mathrm{kgCO} \mathrm{C}_{2} \mathrm{e} / \mathrm{kWh}=$ kilogram of carbon dioxide equivalent per kilowatt-hour, $\mathrm{NO}_{\mathrm{x}}=$ nitrogen oxides, $\mathrm{PM}_{2.5}=$ particulate matter.

a Based on IEA data for 2015.

b Basically, vehicles from Europe and the Russian Federation are imported and thus compliance with Euro 4 standard as minimum can be assumed.

c \$2010; based on IMF. 2014. Getting Energy Prices Right. Washington, DC, Annex 4.2.

Source: Grütter Consulting.

\subsubsection{Electric Buses for Tbilisi}

Tbilisi operates nearly 150 new CNG Euro VI 12-meter (m) low-floor buses and nearly 800 badly maintained Euro II diesel units of $6 \mathrm{~m}, 8 \mathrm{~m}$, and $10 \mathrm{~m}$. The trolleybus system which operated previously in the city was abandoned some years ago.

The city plans to replace the old units within the next 2 years with Euro VI diesel and/or CNG units, with around $50 \%$ of buses to be purchased as $8-\mathrm{m}$ units and the remaining as $10-\mathrm{m}$ buses. Figure 55 compares the GHG emissions of 8-m and 10-m diesel, CNG-powered, and battery electric buses with the grid factor of Georgia.

The WTW GHG emissions of CNG units are higher than of diesel units. In the case of Tbilisi, electric units reduce GHG emissions by around 90\%. Annual GHG emissions could be reduced by around $50,000 \mathrm{tCO}_{2}$ e by purchasing electric units instead of $4008-\mathrm{m}$ diesel buses and $40010-\mathrm{m} \mathrm{CNG}$ units. ${ }^{173}$

Currently, Tbilisi operates a flat electricity tariff without differentiating day or night in tariffs. There is a plan, however, to start differentiating night and day price of electricity in a few years. With a flat tariff and current price structures of battery electric buses (BEBs), it will always be more advantageous in financial terms to purchase buses with a limited battery pack and realize fast-charging during the day as the electricity cost will be the same, but the CAPEX of buses would be much lower. The electricity demand of 800 urban e-buses is less than $38 \mathrm{GWh}$ per annum and thus marginal. ${ }^{174}$ Georgia's hydropower alone is estimated by the Ministry of Economy and Sustainable Development at 50,000 GWh, i.e., a thousand times more than current electricity demand for e-buses in Tbilisi. ${ }^{175}$

$173750,000 \mathrm{tCO}_{2}$ e over the estimated life span of 16 years of buses.

174 This represents around $0.3 \%$ of the national electricity production of 2018 (electricity production data from the Ministry of Economy and Sustainable Development of Georgia).

175 Data presented by D. Sharikadze and M. Arabidze from the Ministry of Economy and Sustainable Development of Georgia at ADB meeting on 13 July 2018 in Tbilisi. 


\section{Figure 55: Greenhouse Gas Emissions-8-Meter and 10-Meter Urban Buses in Georgia $\left(\mathrm{gCO}_{2} \mathrm{e} / \mathrm{km}\right)$}

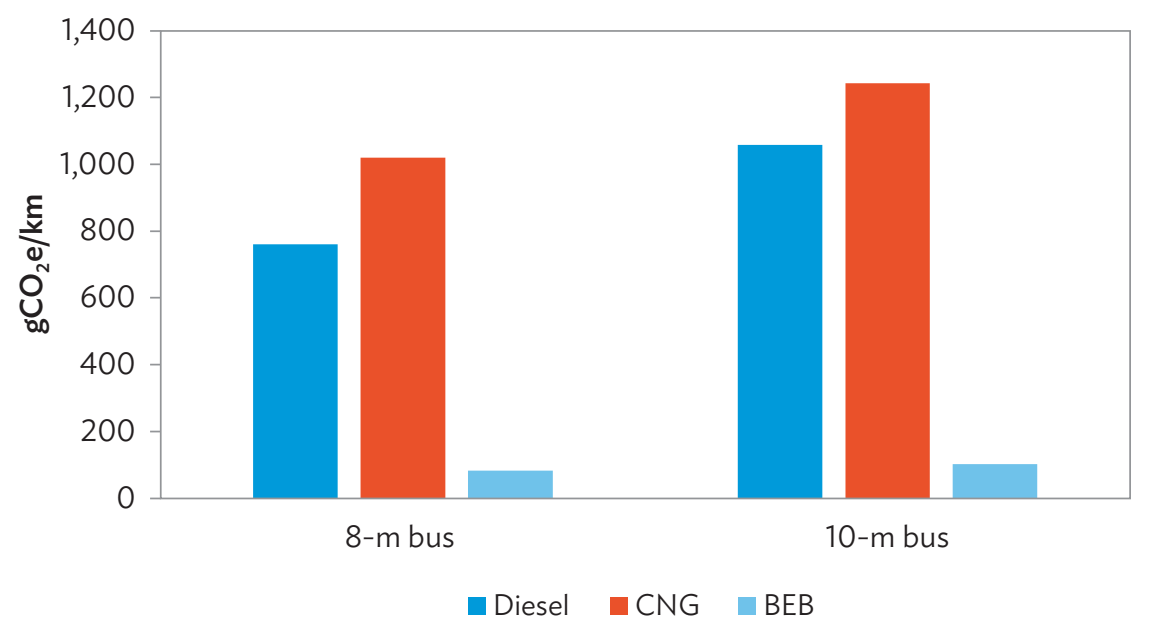

$\mathrm{BEB}=$ battery electric bus, $\mathrm{CNG}=$ compressed natural gas, $\mathrm{gCO}_{2} \mathrm{e} / \mathrm{km}=$ gram of carbon dioxide equivalent per kilometer, PRC = People's Republic of China, WTW = well-to-wheel.

Source: Grütter Consulting, based on energy consumption values of multiple cities in the PRC for CNG, diesel, and BEBs; WTW includes upstream fuel and electricity emissions as well as methane slip; see Appendix for details.

\subsubsection{Conclusions}

Purchasing new fossil fuel units will lock the country's public transport sector in high carbon emissions for the next 2 decades without taking advantage of the very low carbon grid factor and the availability of a national power source for buses. Also, while new Euro 6 units theoretically have very low emissions, this might not be sustained in the medium term if maintenance is not performed properly. Old buses are badly maintained and are most probably below their original emission standard.

The same can happen with new units thus helping to create high pollution levels in the city. As an example, field measurements on diesel buses running with diesel particle filters in Santiago de Chile in 2015 showed that around $20 \%$ of buses had malfunctioning diesel filters running at efficiency levels of around 50\%. ${ }^{176}$ Maintenance diesel filters is not only costly, but also technically demanding. Buses running with badly maintained DPFs might well have pollution levels comparable to Euro 2 buses. This risk is avoided if BEBs are used, thus ensuring low pollution levels which cannot be guaranteed if CNG-or diesel buses are purchased.

While e-buses do result in a higher investment, they can compete with fossil fuel buses in total cost of ownership, especially if compared to CNG Euro 6 units purchased from Europe. The strategy to buy fossil fuel units is environmentally not optimal in terms of GHGs as well as in terms of risking high pollution levels, and might well be financially not optimal also for the city. It would thus be highly recommendable to assess, based on real-world performance and financial data, the relative profitability and impact of

176 Measurements realized by a SDC financed project; see Grütter Consulting. 2015. 
BEBs against the proposed fossil fuel buses, including the potential availability of compensating financial mechanisms.

\subsection{Yerevan: Electric Buses}

\subsubsection{Country and City Circumstances}

\section{National Circumstances}

In its Nationally Determined Contribution, Armenia specifically mentions electric transportation as the main contributor toward GHG mitigation for the transport sector. The new Government of Armenia is very much interested in promoting e-mobility and in making the country a showcase for sustainable mobility. Tax incentives have been established with zero import taxes for EVs (conventional vehicles pay up to $32 \%$ including value-added tax). Armenia, however, imports used cars and even for new cars, the price gap will still be significant, therefore the impact of this specific policy might be limited, but symbolizes an initial step toward e-mobility. Table 22 gives a snapshot of the potential environmental impact of EVs in Armenia.

\section{Yerevan}

As of 2018, Yerevan has an estimated population of 1.1 million inhabitants. ${ }^{177}$ The Yerevan Master Plan for 2006-2020 plans to increase the passenger share of trolleybuses from 3\% to $24 \%$. The city operates one metro line with eight stations and the national government is very much interested in expanding metro services and lines. However, this might face some significant financial hurdles and even with additional metro lines, the city will still require an extensive bus system to accommodate all public transport trips. The national government is interested in exploring options of e-mobility for public transport.

Table 22: Environmental Impact of Electric Vehicles in Armenia

\begin{tabular}{lll}
\hline Criteria & \multicolumn{1}{c}{ Situation } & \multicolumn{1}{c}{ Comment } \\
\hline $\begin{array}{l}\text { GHG impact of } \\
\text { EVs }\end{array}$ & Electricity grid factor $0.16 \mathrm{kgCO}_{2} \mathrm{e} / \mathrm{kWh}^{\mathrm{a}}{ }^{2}$ & $\begin{array}{l}\text { The grid factor of Armenia is very low resulting in emission } \\
\text { reductions of around } 90 \% \text { compared to fossil fuel vehicles. }\end{array}$ \\
$\begin{array}{ll}\text { Local pollution } \\
\text { impact of EVs }\end{array}$ & $\begin{array}{l}\text { Armenia has Euro } 5 \text { emission standards } \\
\text { for vehicles and pollution costs of } \\
\$ 82,000 \text { per ton of } \mathrm{PM} \mathrm{M}_{2.5} \text { and } \$ 620 \text { per } \\
\text { ton of } \mathrm{NO}_{\mathrm{x}}{ }^{\mathrm{b}} \text { which is below the median } \\
\text { level of } \mathrm{DMCs} \text { of } \mathrm{ADB} .\end{array}$ & $\begin{array}{l}\text { The impact of an } \mathrm{EV} \text { on local pollution levels is limited } \\
\text { compared to a conventional new vehicle due to having } \\
\text { the vehicle emission standard Euro } \mathrm{V} \text { and relatively low } \\
\text { pollution costs. }\end{array}$ \\
\hline
\end{tabular}

$\mathrm{ADB}=\mathrm{Asian}$ Development Bank, $\mathrm{DMC}=$ developing member country, $\mathrm{EV}=$ electric vehicle, $\mathrm{GHG}=$ greenhouse gas, $\mathrm{kgCO} \mathrm{e}_{2} / \mathrm{kWh}=$ kilogram of carbon dioxide equivalent per kilowatt-hour, $\mathrm{NO}_{\mathrm{x}}=$ nitrogen oxide, $\mathrm{PM}_{2.5}=$ particulate matter.

a Based on IEA data for 2015.

b \$2010; based on IMF. 2014. Getting Energy Prices Right. Washington, DC, Annex 4.2.

Source: Grütter Consulting.

177 Central Intelligence Agency. Armenia. https://www.cia.gov/library/publications/the-world-factbook/geos/am.html (accessed 18 October 2018). 


\subsubsection{Electric Buses for Yerevan}

The trolleybus system is outdated and services are not frequent. Bus services are basically provided by a fleet of old small and medium-sized buses. Public transport is based on CNG units and a replacement of the outdated fleet is previewed.

The e-bus options available for Yerevan include:

- Renovation and upgrading of the existing trolleybus system using electric trolleybuses which can operate without overhead wiring on ranges of $10-20 \mathrm{~km}$. This option is especially interesting if the trolleybus infrastructure can be partially used or upgraded with less investment than establishing a new system. The advantage of trolleybuses in Yerevan is also that the city and the bus operator have experience in operating and maintaining such a system.

- Using opportunity charge buses for high frequency routes. This option can be more cost-effective and requires less infrastructure investment than new trolleybus lines. It is however basically useful for high density routes and such operating with large, especially articulated, buses.

- Battery E-buses (BEBs) either slow charged during the night or slow plus fast charged during the day. Which option is more cost-effective needs to be studied in detail for Yerevan and basically depends on differential electricity consumption charges, electricity power charges, route and bus characteristics, and charger and e-bus costs. Slow charging, in general, results in lower electricity prices (due to night charging and lower power demand), but higher bus investment, while intermediate fast charging during the day results in lower bus investment and less batteries on board the buses (also reducing bus weight) while having slightly higher electricity prices and system complexity. BEBs are especially effective for $6-\mathrm{m}, 8-\mathrm{m}, 10-\mathrm{m}$, and $12-\mathrm{m}$ buses, while for bigger units (articulated or bi-articulated units), opportunity charging and electric trolleybuses are the best available solution in technical and financial terms.

The GHG impact of purchasing electric units instead of CNG units has been modeled for the bus fleet of Yerevan. Figure 56 compares the GHG emissions of a diesel and CNG bus ( $8 \mathrm{~m}$ and $10-12 \mathrm{~m}$ ) with a $\mathrm{BEB}$, per annum with the grid factor of Armenia.

Based on energy consumption values of 8-m and 10-12-m buses, GHG emissions of CNG units are higher than diesel units. In the case of Yerevan, electric units reduce GHG emissions by more than $85 \%$.

\subsubsection{Conclusions}

Purchasing new fossil fuel bus units will lock Armenia into high carbon emissions by the public transport sector for approximately the next 2 decades, and does not take advantage of the country's very low carbon grid factor and the availability of a national power source for buses.

Also, while new Euro 5 units theoretically have very low emissions, this might not be sustained in the medium term if maintenance is not performed properly. For example, field measurements conducted on diesel buses running with diesel particle filters (DPF) in Santiago de Chile in 2015 showed that around $20 \%$ of buses had a malfunctioning DPF running at efficiency levels of around $50 \% .{ }^{178}$ Maintenance of DPFs is not only costly but also technically demanding. Buses running with badly maintained DPFs might

${ }^{178}$ Measurements realized by a SDC financed project; see Grütter Consulting. 2015. CALAC Evaluation Report. 
Figure 56: Greenhouse Gas Emissions-8-Meter and 10-12-Meter Urban Buses $\left(\mathrm{gCO}_{2} \mathrm{e} / \mathrm{km}\right)$

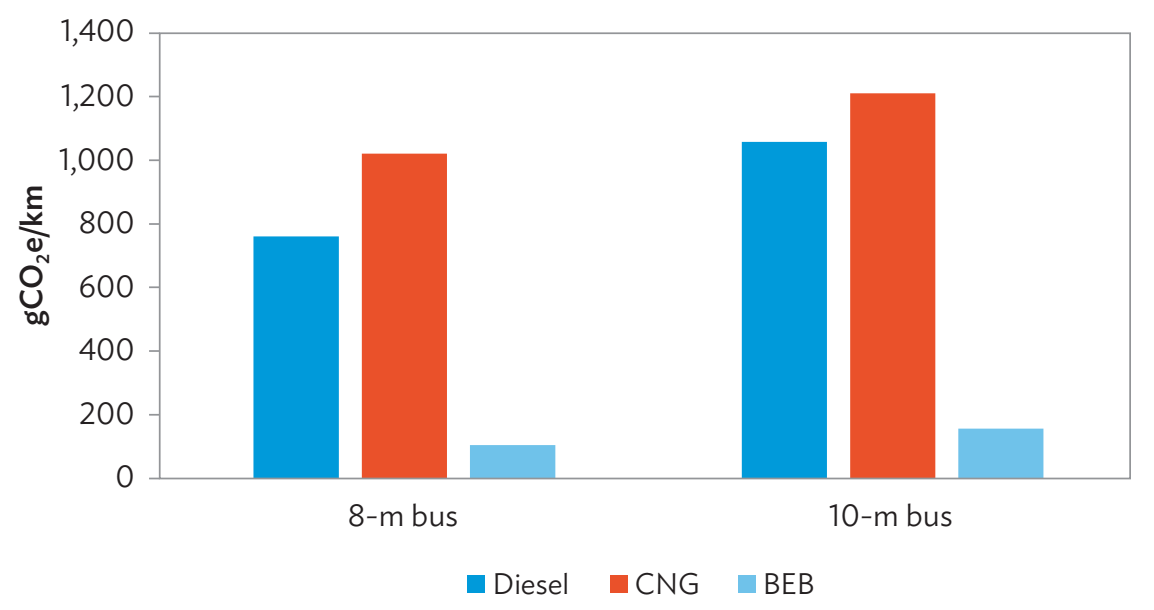

$\mathrm{BEB}=$ battery electric bus, $\mathrm{CNG}=$ compressed natural gas, $\mathrm{gCO}_{2} \mathrm{e} / \mathrm{km}=$ gram of carbon dioxide equivalent per kilometer, PRC = People's Republic of China, WTW = well-to-wheel.

Source: Grütter Consulting, based on energy consumption values of multiple cities in the PRC for CNG, diesel, and BEBs; 10-12-meter bus based on average of 10-12-meter units; WTW includes upstream fuel and electricity emissions as well as methane slip; see Appendix for details.

well have pollution levels comparable to Euro 2 buses. This risk can be avoided if BEBs are used, thus ensuring low pollution levels which cannot be guaranteed if CNG or diesel buses are purchased.

While e-buses do result in a higher investment, they can compete with fossil fuel buses in total cost of ownership. The strategy to buy fossil fuel units is environmentally not optimal in terms of GHGs as well as in terms of risking high pollution levels, and might well be financially not optimal also for the city. It would thus be highly recommendable to assess, based on real-world updated performance and financial data, the relative profitability and impact of BEBs against fossil fuel buses, including the potential availability of compensating financial mechanisms.

\subsection{Karachi: Electric Buses and Integration with Electric Last-Mile Connectivity}

\subsubsection{Country and City Circumstances}

\section{National Circumstances}

Apart from reduced customs duties, Pakistan has no specific incentives for EVs. EVs could reduce urban air pollution significantly. Table 23 gives a snapshot of the potential environmental impact of EVs in Pakistan. 
Table 23: Environmental Impact of Electric Vehicles in Pakistan

\begin{tabular}{|c|c|c|}
\hline Criteria & Situation & Comment \\
\hline $\begin{array}{l}\text { GHG impact of } \\
\text { EVs }\end{array}$ & Electricity grid factor $0.5 \mathrm{kgCO}_{2} \mathrm{e} / \mathrm{kWh}^{\mathrm{a}}$ & $\begin{array}{l}\text { The grid factor has improved in the last } 2 \text { decades by nearly } \\
2 \% \text { annually. Depending on the vehicle type, the grid factor } \\
\text { results in emission reductions by } 50 \%-70 \% \text { compared to } \\
\text { fossil fuel vehicles. }\end{array}$ \\
\hline $\begin{array}{l}\text { Local pollution } \\
\text { impact of EVs }\end{array}$ & $\begin{array}{l}\text { Pakistan has Euro } 2 \text { emission standards } \\
\text { and pollution costs of } \$ 18,000 \text { per ton of } \\
\mathrm{PM}_{2.5} \text { and } \$ 130 \text { per ton of } \mathrm{NO}_{\times}^{\mathrm{b}} \text { which is at } \\
\text { the lower level of DMCs of ADB. }\end{array}$ & $\begin{array}{l}\text { The impact of an EV on local pollution levels is high due } \\
\text { to the high sulfur contents of fuels and the low vehicle } \\
\text { emission standards applied. }\end{array}$ \\
\hline
\end{tabular}

$\mathrm{ADB}=\mathrm{Asian}$ Development Bank, $\mathrm{DMC}=$ developing member country, $\mathrm{EV}=$ electric vehicle, $\mathrm{GHG}=$ greenhouse gas, $\mathrm{kgCO}{ }_{2} \mathrm{e} / \mathrm{kWh}=$ kilogram of carbon dioxide equivalent per kilowatt-hour, $\mathrm{NO}_{\mathrm{x}}=$ nitrogen oxide, $\mathrm{PM}_{2.5}$ = particulate matter.

a Based on IEA data for 2015.

b \$2010; based on IMF. 2014. Getting Energy Prices Right. Washington, DC, Annex 4.2.

Source: Grütter Consulting.

\section{Karachi}

Karachi is the largest city of Pakistan and is the country's main seaport, economic, and financial center. The population of this fast-expanding megacity is estimated at 15 million, according to the last 2017 census, and 23 million for the metropolitan area. One of the most densely populated cities in the world, Karachi is consistently ranked as one of the world's most unlivable cities. ${ }^{179}$ Traffic congestion and induced air and noise pollution play a major role in these poor rankings. Karachi's current transportation system includes informal paratransit vehicles and approximately 4,000 privately owned buses. The city is in the process of constructing a bus rapid transit system with multiple open bus lanes operated with $9-m, 12-m$, and 18-m buses and linked together with last-mile connectivity services. ADB is financing the BRT red-line which shall start operations in 2020 with around 200 buses. Within this project, an assessment of the potential of low-carbon buses was made including hybrid, plug-in hybrid electric, and biomethane-hybrid buses. ${ }^{180}$ The project also includes last-mile connectivity services with e-pedicabs.

\subsubsection{Zero-Emission Integrated Bus Systems ${ }^{181}$}

Table 24 shows the main characteristics of e-buses (exemplified with 12-m buses) and the expected impacts of using e-buses versus diesel Euro 2 units in the BRT. ${ }^{182}$

Annual GHG reductions of $10,000 \mathrm{tCO}_{2}$ are achievable using e-buses with the current grid factor of Pakistan. However, total costs of ownership are 20\% higher than conventional buses, requiring substantial subsidies. Also, the electric system of Karachi is relatively unstable with many blackouts and with problems to cover peak demands. As an alternative, using biomethane buses was assessed with Karachi having a very large potential to produce biomethane derived from cattle waste dumped currently in the sea in the larger urban zone of the city. This solution is not only much cheaper than e-buses (with

179 The Economist Intelligence Unit. 2017. Global Liveability Report. London. Karachi ranks 134 out of 140 cities.

180 In a similar project of ADB in Peshawar, the decision was made to purchase plug-in hybrid units linked with fast chargers along the BRT route and with a solar PV system to supply the required electricity.

181 Section based on Grütter Consulting. 2018b. GHG and Air Quality Impact of the BRT Karachi and Assessment of Technology Options for BRT Buses.

182 The diesel sulfur level in Pakistan only allows to operate Euro III emission standard buses and not more advanced units. 
Table 24: Comparison Diesel and Electric Bus for Karachi (12-Meter Standard Urban Bus with Air-Conditioning)

\begin{tabular}{|c|c|c|}
\hline Parameter & Diesel Bus & e-Bus ${ }^{a}$ \\
\hline Energy usage & 33 liters/100 km & $1.14 \mathrm{kWh} / \mathrm{km}$ \\
\hline GHG emissions per annum & $\begin{array}{c}\text { TTW: } 49 \mathrm{tCO}_{2} \mathrm{e} \\
\text { WTW including } \mathrm{BC}: 70 \mathrm{tCO}_{2} \mathrm{e}\end{array}$ & $\begin{array}{l}\text { TTW: } 0 \mathrm{tCO}_{2} \mathrm{e} \\
\text { WTW: } 31 \mathrm{tCO}_{2} \mathrm{e}\end{array}$ \\
\hline Pollution costs lifetime bus ${ }^{b}$ & $\$ 5,300$ & $\$ 0$ \\
\hline CAPEX & $\$ 140,000^{c}$ & $\$ 330,000^{d}$ \\
\hline OPEX average per annume & $\$ 16,000$ & $\$ 9,000$ \\
\hline TCO per km ${ }^{f}$ & $\$ 0.50 / \mathrm{km}$ & $\$ 0.60 / \mathrm{km}$ \\
\hline
\end{tabular}

$\mathrm{BC}=$ black carbon, $\mathrm{CAPEX}=$ capital expenditure, $\mathrm{GHG}=$ greenhouse gas, $\mathrm{km}=$ kilometer, $\mathrm{OPEX}=$ operational expenditure, $\mathrm{tCO} \mathrm{O}_{2} \mathrm{e}=\mathrm{ton}$ of carbon dioxide equivalent, TCO = total cost of ownership, TTW = tank-to-wheel, WTW = well-to-wheel.

a Based on optimizing costs of buses versus electricity; BEB with $180 \mathrm{kWh}$ and intermediate charging using $200 \mathrm{~kW}$ fast-chargers.

b Includes cost of $\mathrm{PM}_{2.5}, \mathrm{SO}_{2}$, and $\mathrm{NO}_{x}$ valued at environmental pollution costs for Pakistan based on IMF. 2014.

c Bus life span of 12 years.

d Bus $\$ 310,000$ and charger $\$ 20,000$ per bus (6:1 relation bus to fast charger plus one slow charger per bus); bus life span of 16 years and battery life span of 8 years.

e Includes energy and maintenance cost including tires.

f Financial TCO includes discounting at $10 \%$; annual mileage $56,000 \mathrm{~km}$.

Source: Grütter Consulting. 2018. GHG and Air Quality Impact of the BRT Karachi and Assessment of Technology Options for BRT Buses.

a TCO comparable to diesel units), but also technically simpler than electric units and with a larger GHG impact due to not having upstream emissions from electricity production, i.e., the GHG impact of the project is $19,000 \mathrm{tCO}_{2}$ reduced per annum instead of $10,000 \mathrm{tCO}_{2}$ as with electric units. The example shows clearly that EV technology is not in all cases the most appropriate technical, environmental, and financial solution for achieving zero-emission mobility.

The second component of the project is to integrate non-motorized transport and e-pedicabs for last-mile connectivity of the bus system, increasing the attractiveness of the system and allowing for multimodal usage. In total, 300 e-pedicabs shall be integrated with the system, replacing primarily motorized rickshaws.

Annual estimated emission reductions are around $400 \mathrm{tCO}_{2} \mathrm{e} .{ }^{183}$ While $\mathrm{GHG}$ reductions are small, the social and pollution impacts are very positive, including improved air quality, reduced noise, and improved social acceptability compared to human-powered rickshaws. E-pedicabs combined with zero-emission buses can therefore form an interesting combination for an integrated multimodal zero-emission public transport system.

\subsubsection{Conclusions}

E-buses can be used in BRT systems. However, other solutions including biomethane buses might be financially, technically, and environmentally more attractive as zero-emission buses, especially if the grid is still carbon intensive, fossil fuel prices are low, and electricity supply is relatively unstable. The suitability of technical options toward low-carbon mobility should thus be considered in a comprehensive manner to allow for an optimal and cost-effective solution.

183 Based on replacing CNG rickshaws; daily mileage of $30 \mathrm{~km}$. 
BRT as well as other public transport systems not only require mass transport solutions but also last-mile connectivity services. E-mobility can play an important role in addressing this part. This also includes the usage of modern e-pedicabs, which allow for a convenient and environmentally friendly transport of passengers to and from the public transport system, thus resulting in integrated zero-emission public transport system. While the direct GHG impact of this component in isolation is relatively small, it does allow for a more attractive and convenient public transport system, thereby also increasing users of the mass transit system.

\subsection{Bangkok: Electric Trucks}

\subsubsection{Country and City Circumstances}

\section{National Circumstances}

Vehicle excise tax is $2 \%-10 \%$ for locally produced $\mathrm{EVs}$ and $10 \%-30 \%$ for conventional vehicles. The government also provides tax breaks for charging stations. Government offices are encouraged to allot $20 \%$ of budget to buy EVs, and the Bangkok Mass Transit Authority must buy 200 BEBs. Thailand is specifically promoting the production of EVs, with import exemptions for equipment and tax breaks. Table 25 gives a snapshot of the potential environmental impact of EVs in Thailand.

\section{Bangkok}

The estimated population of Bangkok is 10.2 million inhabitants. ${ }^{184}$ In 2014, Thailand had registered around 800,000 trucks, of which more than $90 \%$ are diesel units and the rest natural gas-powered. ${ }^{185}$ Annual average vehicle mileage of trucks in Bangkok is estimated at around 40,000 km per truck. ${ }^{186}$

Table 25: Environmental Impact of Electric Vehicles in Thailand

\begin{tabular}{|c|c|c|}
\hline Criteria & Situation & Comment \\
\hline $\begin{array}{l}\text { GHG impact of } \\
\text { EVs }\end{array}$ & Electricity grid factor $0.55 \mathrm{kgCO}_{2} \mathrm{e} / \mathrm{kWh} .^{\mathrm{a}}$ & $\begin{array}{l}\text { The grid factor has improved in the last } 2 \text { decades by } \\
\text { nearly } 2 \% \text { annually. Based on vehicle type, the grid factor } \\
\text { results in emission reductions by } 50 \%-70 \% \text { compared to } \\
\text { fossil fuel vehicles. }\end{array}$ \\
\hline $\begin{array}{l}\text { Local pollution } \\
\text { impact of EVs }\end{array}$ & $\begin{array}{l}\text { Thailand has Euro } 4 \text { emission standards } \\
\text { and pollution costs of } \$ 59,000 \text { per ton of } \\
\mathrm{PM}_{2.5} \text { and } \$ 420 \text { per ton of } \mathrm{NO}_{\mathrm{x}}^{\mathrm{b}} \text { which is } \\
\text { above the median level of } \mathrm{DMCs} \text { of } \mathrm{ADB} \text {. }\end{array}$ & $\begin{array}{l}\text { The impact of an EV on local pollution levels is limited } \\
\text { compared to a conventional new vehicle due to } \\
\text { application of the vehicle emission standard Euro } 4 .\end{array}$ \\
\hline
\end{tabular}

$\mathrm{ADB}=$ Asian Development Bank, $\mathrm{DMC}=$ developing member country, $\mathrm{EV}=$ electric vehicle, $\mathrm{GHG}=$ greenhouse gas, $\mathrm{kgCO} \mathrm{e}_{2} / \mathrm{kWh}=$ kilogram of carbon dioxide equivalent per kilowatt-hour, $\mathrm{NO}_{\mathrm{x}}=$ nitrogen oxide, $\mathrm{PM}_{2.5}=$ particulate matter.

a Based on IEA data for 2015.

b \$2010; based on IMF, 2014, Annex 4.2.

Source: Grütter Consulting.

\footnotetext{
184 Central Intelligence Agency. Major Urban Areas - Population. https://www.cia.gov/library/publications/the-world-factbook/ fields/2219.html (accessed 18 October 2018).

185 AJPT data.

186 Limamond et al. 2009 cited in GIZ. 2016. Monitoring Greenhouse Gas Emissions in Thailand's Transport Sector.
} 


\subsubsection{Electric Trucks for Bangkok}

The number of trucks and their average tonnage within Bangkok is not known. Bangkok operates various urban freight consolidation centers, which improves the delivery system of freight and reduces movement, especially of heavy trucks within the city. Freight consolidation centers could be the entry points and operators of e-trucks.

E-trucks are pushing increasingly into the market. Various manufacturers have started producing electric delivery trucks and electric vans or e-vans primarily with payloads of 1-6 tons.

The CAPEX differential of electric delivery trucks is still high compared to diesel units. However, energy and maintenance costs are much lower and energy costs help reduce urban air pollution and noise. Also, driving ranges and payload required for urban trucks is much lower than for inter-urban units. A pilot fleet of 50 urban delivery trucks could avoid around 5,000 $\mathrm{tCO}_{2} \mathrm{e}$ in annual emissions, thus allowing testing of zero-emission urban freight systems. With the grid factor projected to reduce in the next decade due to planned increase of renewable energy production, this value would increase. 


\section{APPENDIX 1: GREENHOUSE GAS EMISSIONS BASELINE VEHICLE}

\section{General Parameters}

\begin{tabular}{|c|c|c|c|}
\hline Parameter & Value & Unit & Source \\
\hline NCV of diesel & 43 & $\mathrm{MJ} / \mathrm{kg}$ & IPCC, 2006, Table 1.2. \\
\hline $\mathrm{CO}_{2}$ emission factor of diesel & 74.1 & $\mathrm{gCO}_{2} / \mathrm{MJ}$ & IPCC, 2006, Table 1.4 \\
\hline Density of diesel & 0.844 & kg/l & IEA, 2005 \\
\hline Well-to-tank mark-up factor diesel & $23 \%$ & & UNFCCC, 2014, Table 3. \\
\hline NCV of CNG/LNG & 48 & $\mathrm{MJ} / \mathrm{kg}$ & IPCC, 2006, Table 1.2. \\
\hline $\mathrm{CO}_{2}$ emission factor of $\mathrm{CNG} / \mathrm{LNG}$ & 56.1 & $\mathrm{gCO}_{2} / \mathrm{MJ}$ & IPCC, 2006, Table 1.4 \\
\hline Density of NG & 0.714 & $\mathrm{~kg} / \mathrm{m}^{3}$ & IGU, 2012 \\
\hline Well-to-tank mark-up factor CNG & $18 \%$ & & UNFCCC, 2014, Table 3. \\
\hline Well-to-tank mark-up factor LNG & $29 \%$ & & UNFCCC, 2014, Table 3. \\
\hline $\begin{array}{l}\text { Methane slip as \% of NG consumption } \\
\text { TTW }\end{array}$ & $1.1 \%$ & & $\begin{array}{l}\text { Average low and high value of ICCT, 2015, Table } 4 \\
\text { for crankcase and tailpipe. }\end{array}$ \\
\hline $\begin{array}{l}\text { Methane slip as \% of NG consumption } \\
\text { WTW }\end{array}$ & $3.4 \%$ & & $\begin{array}{l}\text { Average low and high value of ICCT, 2015, Table } 4 \\
\text { for well-to-pump and fuelling station plus TTW slip. }\end{array}$ \\
\hline NCV of gasoline & 44.3 & $\mathrm{MJ} / \mathrm{kg}$ & IPCC, 2006, Table 1.2 \\
\hline $\mathrm{CO}_{2}$ emission factor of gasoline & 69.3 & $\mathrm{gCO}_{2} / \mathrm{MJ}$ & IPCC, 2006, Table 1.4 \\
\hline Density of gasoline & 0.741 & kg/l & IEA, 2005 \\
\hline Well-to-tank mark-up factor gasoline & $19 \%$ & & UNFCCC, 2014, Table 3. \\
\hline $\mathrm{GWP}_{100}$ of $\mathrm{BC}$ & 900 & & Bond, 2013; see also IPCC, 2013, Table 8.A.6. \\
\hline $\mathrm{BC}$ fraction Euro IV diesel passenger car & $87 \%$ & & EEA, 2016, Table 3-117. \\
\hline $\mathrm{BC}$ fraction Euro IV HDVs & $75 \%$ & & EEA, 2016, Table 3-117. \\
\hline $\mathrm{GWP}_{100}$ of $\mathrm{CH}_{4}$ & 28 & & IPCC, 2013, Table 8.A. \\
\hline $\mathrm{PM}_{2.5}$ emission diesel Euro IV urban bus & 0.0462 & $\mathrm{~g} / \mathrm{km}$ & COPERT, Table 3-23, Tier 2 approach. \\
\hline $\begin{array}{l}\mathrm{PM}_{2.5} \text { emission diesel passenger car Euro } \\
\text { IV } 1.4-2.0\end{array}$ & 0.0314 & $\mathrm{~g} / \mathrm{km}$ & COPERT, Table 3-17, Tier 2 approach. \\
\hline $\mathrm{PM}_{2.5}$ emission diesel truck Euro IV $>32 \mathrm{t}$ & 0.0268 & $\mathrm{~g} / \mathrm{km}$ & COPERT, Table 3-22, Tier 2 approach. \\
\hline $\mathrm{PM}_{2.5}$ emission diesel truck Euro IV $<7 \mathrm{t}$ & 0.0106 & $\mathrm{~g} / \mathrm{km}$ & COPERT, Table 3-22, Tier 2 approach. \\
\hline Grid factor DMCs lower 20 percentile & 0.352 & $\mathrm{kgCO}_{2} / \mathrm{kWh}$ & Grütter Consulting. \\
\hline Grid factor DMCs upper 20 percentile & 0.794 & $\mathrm{kgCO}_{2} / \mathrm{kWh}$ & \\
\hline Worst DMC grid & 1.05 & $\mathrm{kgCO}_{2} / \mathrm{kWh}$ & \\
\hline Median grid factor DMC & 0.655 & $\mathrm{kgCO}_{2} / \mathrm{kWh}$ & \\
\hline Average diesel price DMC & 0.81 & $\$ / 1$ & Median prices June 2018; see sheet fuel prices. \\
\hline Average gasoline price DMC & 0.93 & $\$ / l$ & \\
\hline Average assumed electricity price & 0.16 & $\$ / \mathrm{kWh}$ & $\begin{array}{l}\text { Huge variations per country; average of PRC } \\
\text { including service charge. }\end{array}$ \\
\hline Average CNG price & 0.6 & $\$ / \mathrm{kg}$ & $\begin{array}{l}\text { Large variations; based on India for June 2018; } \\
\text { https://www.drivespark.com/cng-price-in-delhi/. }\end{array}$ \\
\hline $\mathrm{SO}_{2}$ emissions per liter of diesel & 0.084 & $\mathrm{gSO}_{2} / \mathrm{I}$ & $\begin{array}{l}\text { Based on molecular weight of } \mathrm{S} \text { against } \mathrm{SO}_{2} \text { with } \\
50 \mathrm{ppm} \text { sulfur diesel (Euro } 4 \text { diesel). }\end{array}$ \\
\hline
\end{tabular}

$\mathrm{BC}=$ black carbon, $\mathrm{CH}_{4}=$ methane, $\mathrm{CNG}=$ compressed natural gas, $\mathrm{CO}_{2}=$ carbon dioxide, $\mathrm{COPERT}=$ Computer Program to calculate Emissions from Road Transport, DMC = developing member country, EEA = European Economic Area, gCO $/ \mathrm{MJ}_{2}$ grams of carbon dioxide per megajoule, $\mathrm{g} / \mathrm{km}=$ gram per kilometer, $\mathrm{gSO}_{2} / \mathrm{I}=$ grams of sulfur dioxide per liter, $\mathrm{GWP}_{100}=$ global warming potential over 100 years, $\mathrm{HDV}$ s = heavy-duty vehicles, ICCT = International Council on Clean Transportation, IEA = International Energy Agency, IGU = International Gas Union, IPCC = Intergovernmental Panel on Climate Change, $\mathrm{kgCO}_{2} / \mathrm{kWh}=$ kilograms of carbon dioxide per kilowatt hour, $\mathrm{kg} / \mathrm{l}=$ kilogram per liter, $\mathrm{kg} / \mathrm{m}^{3}=$ kilogram per cubic meter, $\mathrm{LNG}=$ liquefied natural gas, $\mathrm{MJ} / \mathrm{kg}=\mathrm{megajoules}$ per kilogram, $\mathrm{NCV}=$ net calorific value, $\mathrm{NG}=$ natural gas, $\mathrm{PM}_{2.5}=$ particulate matter with a diameter of less than 2.5 micrometers, ppm = parts per million, $\mathrm{PRC}=$ People's Republic of China, $\mathrm{S}=$ sulfur, $\mathrm{SO}_{2}=$ sulfur dioxide, TTW = tank-to-wheel, UNFCCC = United Nations Framework Convention on Climate Change, $\$ / \mathrm{l}=$ dollars per liter, $\$ / \mathrm{kg}=$ dollars per kilogram, $\$ / \mathrm{kWh}=$ dollars per kilowatt hour, WTW = wheel-to-wheel. 


\section{Motorcycle Specific Parameters}

\begin{tabular}{|c|c|c|c|}
\hline Parameter & Value & Unit & Source \\
\hline Specific fuel consumption gasoline & 2.7 & $\mathrm{l} / 100 \mathrm{~km}$ & $\begin{array}{l}\text { Average between values monitored in Delhi (scooters, } \\
70 \text { cc, 4-stroke; realized by Grütter Consulting, } \\
\text { 2011) and data for Ha Noi based on World Bank, } \\
\text { 2014; engine capacity } 110-125 \text { cc; } 4 \text {-stroke; the fuel } \\
\text { efficiency standard for } 100-125 \mathrm{cc} \text { motorcycles in } \\
\text { PRC is } 2.5 \text { I/100 km. https://www.transportpolicy.net/ } \\
\text { standard/china-motorcycles-fuel-consumption/. }\end{array}$ \\
\hline Annual distance driven & 7,000 & $\mathrm{~km}$ & Data India and Viet Nam; motorcycle engines with \\
\hline Vehicle life span & 7 & years & $\begin{array}{l}<125 \text { cc will typically last 50,000 km; IEA, } 2018 \\
\text { assumes 6-7,500 km/a. }\end{array}$ \\
\hline Electric motorcycle & 0.04 & $\mathrm{kWh} / \mathrm{km}$ & $\begin{array}{l}\text { Average of various Indian manufacturers for } \\
\text { higher powered e-scooters: IEA, } 2018 \text { assumes } \\
0.03-0.05 \mathrm{kWh} / \mathrm{km} \text {. }\end{array}$ \\
\hline CAPEX motorcycle gasoline & 700 & $\$$ & http://www.carbay.vn/en/new-motorcycles/honda. \\
\hline Battery duration & 2 & years & Idem rickshaw. \\
\hline Battery cost & 245 & & Idem rickshaw; $35 \%$ of investment. \\
\hline CAPEX motorcycle electric & 700 & $\$$ & $\begin{array}{l}\text { 1,200W engine, } 100 \mathrm{~km} \text { range; http://oecdinsights. } \\
\text { org/2016/02/12/rest-in-peace-moped-electric- } \\
\text { scooters-are-here/; higher powered electric scooters } \\
\text { like those offered by Gogoro with } 6,400 \text { watts cost } \\
\text { around } \$ 3,500 \text {. }\end{array}$ \\
\hline $\begin{array}{l}\text { CAPEX lifetime including battery } \\
\text { replacement }\end{array}$ & 1,006 & $\$$ & Not discounted; $50 \%$ of current battery prices. \\
\hline
\end{tabular}

CAPEX = capital expenditure, IEA = International Energy Agency, $\mathrm{km}=$ kilometer, $\mathrm{kWh} / \mathrm{km}=$ kilowatt hour per kilometer, $\mathrm{l} / 100 \mathrm{~km}=$ liter per 100 kilometers, $\mathrm{PRC}=$ People's Republic of China, $\mathrm{W}=$ watt.

\section{Passenger Car Specific Parameters}

\begin{tabular}{|c|c|c|c|}
\hline Parameter & Value & Unit & Source \\
\hline Specific fuel consumption gasoline & 7.6 & $\mathrm{l} / 100 \mathrm{~km}$ & $\begin{array}{l}\text { COPERT, Table 3-27, Tier } 2 \text { approach; 08-1.4 I, Euro } 1 \\
\text { and later. }\end{array}$ \\
\hline Annual distance driven & 15,000 & $\mathrm{~km}$ & Typical values of 150,000 km commercial lifetime; \\
\hline Vehicle life span & 10 & years & $\begin{array}{l}\text { average annual mileage in Chinese cities } 20,000 \text { km; } \\
\text { in Indian cities } 8-12,000 \text { km; survival rate India } 90 \% \text {, } \\
10 \text { years; see Goel, } 2015 .\end{array}$ \\
\hline Electric cars & 0.17 & $\mathrm{kWh} / \mathrm{km}$ & $\begin{array}{l}\text { Average of smaller EVs (real world values), ICCT, 2016, } \\
\text { Figure 5; } 10 \text { smaller models in Europe average 0.14, but } \\
\text { based on NEDC cycle UBA, 2016, (ICCT states 40\% } \\
\text { higher real world); IEA, } 2018 \text { assumes } 0.176 .\end{array}$ \\
\hline Car manufacturing emissions & 4.7 & $\mathrm{tCO}_{2}$ & Ecoinvent and mobitool used in EU. \\
\hline Battery set e-car & 30 & $\mathrm{kWh}$ & Nissan Leaf 2017 for 150 km range. \\
\hline Battery manufacturing emissions & 110 & $\begin{array}{l}\mathrm{kgCO}_{2} / \\
\mathrm{kWh} \\
\text { battery }\end{array}$ & ICCT. 2018. \\
\hline Battery lifetime & 10 & years & Idem to vehicle life span. \\
\hline CAPEX car gasoline & 20,000 & $\$$ & Nissan Sentra SR US. \\
\hline CAPEX car electric & 30,000 & $\$$ & Nissan Leaf US. \\
\hline
\end{tabular}

CAPEX = capital expenditure, COPERT = Computer Program to calculate Emissions from Road Transport, EU = European Union, $\mathrm{ICCT}=$ International Council on Clean Transportation, IEA = International Energy Agency, $\mathrm{kgCO}_{2} / \mathrm{kWh}=$ kilograms of carbon dioxide per kilowatt hour, $\mathrm{km}=$ kilometer, $\mathrm{kWh} / \mathrm{km}=$ kilowatt hour per kilometer, $1 / 100 \mathrm{~km}=$ liter per 100 kilometers, NEDC = New European Driving Cycle, $\mathrm{PRC}=$ People's Republic of China, $\mathrm{tCO}_{2}=$ tons of carbon dioxide, UBA = German Federal Environmental Agency. 


\section{Taxi Specific Parameters}

\begin{tabular}{|c|c|c|c|}
\hline Parameter & Value & Unit & Source \\
\hline Specific fuel consumption diesel & 6.5 & $\mathrm{l} / 100 \mathrm{~km}$ & $\begin{array}{l}\text { COPERT, Table 3-27, Tier } 2 \text { approach; } 1.4-2.0 \text { I; Euro } 1 \text { and } \\
\text { later. }\end{array}$ \\
\hline Lifetime mileage taxi & 400,000 & $\mathrm{~km}$ & $\begin{array}{l}\text { UK 40,000 km/a. https://www.insuretaxi.com/2016/08/ } \\
\text { taxi-driver-survey-2016/. Spain 50,000 km/a. http:// } \\
\text { upcommons.upc.edu/bitstream/handle/2099.1/25853/ } \\
\text { TFM.pdf? sequence=1. Germany 60,000 km/a. http:// } \\
\text { upcommons.upc.edu/bitstream/handle/2099.1/25853/TFM. } \\
\text { pdf? sequence=1. } 8 \text { years lifetime. }\end{array}$ \\
\hline
\end{tabular}

COPERT = Computer Program to calculate Emissions from Road Transport, km = kilometer, $1 / 100$ km = liter per 100 kilometers.

\section{Urban 12-Meter Bus}

\begin{tabular}{|c|c|c|c|}
\hline Parameter & Value & Unit & Source \\
\hline Specific fuel consumption diesel & 35 & $\mathrm{l} / 100 \mathrm{~km}$ & $\begin{array}{l}\text { Average cities in the PRC, the Republic of Korea, India, } \\
\text { Bangladesh; COPERT, Table 3-27 Tier } 2 \text { has a similar value } \\
(0.4 \text { l/100 km higher). }\end{array}$ \\
\hline Annual distance driven & 65,000 & $\mathrm{~km}$ & \multirow{2}{*}{$\begin{array}{l}\text { Typical values of } 1-1.2 \text { million bus-km commercial lifetime } \\
\text { used worldwide; the PRC in general only } 60,000 \mathrm{~km} \text { with } \\
8 \text { years. }\end{array}$} \\
\hline Vehicle life span & 15 & years & \\
\hline E-bus & 1.14 & $\mathrm{kWh} / \mathrm{km}$ & Average of 16 cities in the PRC, Grütter Consulting, 2018. \\
\hline Battery set BEB & 250 & kWh & $\begin{array}{l}\text { Average PRC bus } 200 \mathrm{kWh} \text {; allows for average range of } \\
\text { around } 150 \mathrm{~km} \text { including reserve, i.e.,one-time fast charge } \\
\text { partial per day. }\end{array}$ \\
\hline Bus manufacturing emissions & 64 & $\mathrm{tCO}_{2}$ & Ecoinvent and mobitool used in EU. \\
\hline Lifetime of e-bus versus diesel & $50 \%$ & additional & Due to less vibrations and engine. \\
\hline Battery life span & 8 & years & Average PRC guarantee 2018 with 80\% SOC. \\
\hline Battery cost & 350 & $\$ / \mathrm{kWh}$ & Cost PRC 2017 for bus batteries. \\
\hline Battery manufacturing emissions & 110 & $\begin{array}{l}\mathrm{kgCO}_{2} / \\
\mathrm{kWh} \\
\text { battery }\end{array}$ & ICCT.2018. \\
\hline $\begin{array}{l}\text { Assignment of battery } \\
\text { manufacturing to bus }\end{array}$ & $50 \%$ & & Based on usage for stationary application thereafter. \\
\hline CAPEX diesel buses & 100,000 & $\$$ & \multirow{2}{*}{$\begin{array}{l}\text { Average price excluding subsidy in PRC, Grütter Consulting, } \\
2018 .\end{array}$} \\
\hline CAPEX e-bus & 250,000 & $\$$ & \\
\hline $\begin{array}{l}\text { CAPEX lifetime e-bus including } \\
\text { battery replacement }\end{array}$ & 288,281 & & Not discounted; $50 \%$ of current battery prices. \\
\hline
\end{tabular}

COPERT $=$ Computer Program to calculate Emissions from Road Transport, ICCT = International Council on Clean Transportation, $\mathrm{EU}=$ European Union, $\mathrm{km}=$ kilometer, $\mathrm{kgCO}_{2} / \mathrm{kWh}=$ kilograms of carbon dioxide per kilowatt hour, $\mathrm{kWh}=\mathrm{kilowatt}$ hour, $\mathrm{kWh} / \mathrm{km}=$ kilowatt hour per kilometer, $\mathrm{l} / 100 \mathrm{~km}=$ liter per 100 kilometers, $\mathrm{PRC}=$ People's Republic of China, $\mathrm{SOC}=$ state of charge, $\mathrm{tCO}_{2}=$ tons of carbon dioxide, $\$ / \mathrm{kWh}=$ dollar per kilowatt hour. 


\section{Truck 40-Ton (Diesel)}

\begin{tabular}{|c|c|c|c|}
\hline Parameter & Value & Unit & Source \\
\hline Specific fuel consumption & 37 & $\mathrm{l} / 100 \mathrm{~km}$ & $\begin{array}{l}\text { Value monitored in Viet Nam ADB Green Freight Project } \\
2016 \text { for long-haul } 44 \text { t trucks; COPERT, Table 3-27 Tier } 2 \text { > } \\
32 \text { t has } 30 \text { I/100 km. }\end{array}$ \\
\hline Annual distance driven & 80,000 & $\mathrm{~km}$ & \multirow{2}{*}{$\begin{array}{l}1.2 \text { million km lifetime; long-haul trucks Viet Nam 90,000 km } \\
\text { Lao PDR 50,000 km (GF ADB program); PRC 60,000 km } \\
\text { (see H. Huo, 2011). }\end{array}$} \\
\hline Vehicle life span & 15 & years & \\
\hline
\end{tabular}

$\mathrm{ADB}=$ Asian Development Bank, COPERT = Computer Program to calculate Emissions from Road Transport, GF = Global Fund, $\mathrm{km}=$ kilometer, Lao PDR = Lao People's Domestic Republic, l/100 km = liter per 100 kilometers, PRC = People's Republic of China.

\section{Rickshaw 3-wheeler}

\begin{tabular}{|c|c|c|c|}
\hline Parameter & Value & Unit & Source \\
\hline $\begin{array}{l}\text { Specific fuel consumption CNG } \\
\text { rickshaws }\end{array}$ & 6.3 & $\mathrm{~m}^{3} / 100 \mathrm{~km}$ & $\begin{array}{l}\text { Grütter Consulting, } 2016 \text { based on data of rickshaw operators } \\
\text { in Dhaka, Bangladesh. }\end{array}$ \\
\hline Annual distance driven & 20,000 & $\mathrm{~km}$ & \multirow{2}{*}{$\begin{array}{l}60 \text { km per day calculated with } 330 \text { days per annum; data from } \\
\text { survey in Delhi; Capacities, } 2018 .\end{array}$} \\
\hline Vehicle life span & 5 & years & \\
\hline e-rickshaw & 0.08 & $\mathrm{kWh} / \mathrm{km}$ & Capacities average Delhi and Udaipur, 2018. \\
\hline CAPEX CNG rickshaw & 3,600 & $\$$ & Same as e-rickshaw based on Capacities, 2018. \\
\hline CAPEX e-rickshaw & 3,600 & $\$$ & With Li-ion battery; based on India; 4-seater. \\
\hline $\begin{array}{l}\text { CAPEX e-rickshaw lifetime } \\
\text { including battery replacement }\end{array}$ & 4,575 & $\$$ & Not discounted; $50 \%$ of current battery prices. \\
\hline Battery cost & 1,300 & $\$$ & Capacities, Udaipur, 2018. \\
\hline Battery life span & 2 & years & Capacities, Udaipur, 2018. \\
\hline
\end{tabular}

$\mathrm{CNG}=$ compressed natural gas, $\mathrm{km}=$ kilometer, $\mathrm{kWh} / \mathrm{km}=$ kilowatt hours per kilometer, $\mathrm{m}^{3} / 100 \mathrm{~km}=$ cubic meters per 100 kilometers.

\section{Urban Truck 3.5-7-Ton}

\begin{tabular}{lrcl}
\hline Parameter & Value & Unit & \\
\hline Specific fuel consumption diesel & 12 & I/100 km & COPERT, Table 3-27 Tier 2. \\
Annual distance driven & 40,000 & $\mathrm{~km}$ & 500,000 lifetime mileage. \\
Vehicle life span & 15 & years & \\
e-urban truck & 0.3 & $\mathrm{kWh} / \mathrm{km}$ & Average of work load of Streetscooter. \\
CAPEX diesel truck & 20,000 & $\$$ & E.g., Iveco Daily or Ford Transit. \\
CAPEX e-truck & 50,000 & $\$$ & E.g., Streetscooter. \\
CAPEX e-truck lifetime including & 62,250 & $\$$ & Not discounted; 50\% of current battery prices. \\
battery replacement & & & \\
Battery cost & 350 & $\$ / \mathrm{kWh}$ & Idem to buses. \\
Battery life span & 8 & years & Idem to buses. \\
Battery set & 40 & $\mathrm{kWh}$ & Streetscooter L. \\
\hline
\end{tabular}

COPERT = Computer Program to calculate Emissions from Road Transport, $\mathrm{km}=$ kilometer, $\mathrm{kWh} / \mathrm{km}=$ kilowatt hour per kilometer, $\mathrm{l} / 100 \mathrm{~km}=$ liter per 100 kilometers. 


\section{APPENDIX 2: EMISSION IMPACT PER VEHICLE CATEGORY}

\section{Assumptions}

1. Greenhouse gas (GHG) impact based on well-to-wheel (WTW), including black carbon (BC) with median grid factor developing member countries (DMCs) and Euro IV standard.

2. Pollution impact based on Euro IV standard.

\section{Lifetime Emission Impact}

\begin{tabular}{|c|c|c|c|c|c|c|c|c|}
\hline Vehicle Category & $\begin{array}{c}\mathrm{PM}_{2.5} \\
\text { Reduction } \\
\text { (ton) }\end{array}$ & $\begin{array}{c}\mathrm{NO}_{\mathrm{x}} \\
\text { Reduction } \\
\text { (ton) }\end{array}$ & $\begin{array}{c}\mathrm{SO}_{2} \\
\text { Reduction } \\
\text { (ton) }\end{array}$ & $\begin{array}{c}\text { GHG } \\
\text { Reduction } \\
\text { (ton) }\end{array}$ & $\begin{array}{c}\text { Economic } \\
\text { Value } \\
\text { Lower } 20 \\
\text { Percentile } \\
(\$)\end{array}$ & $\begin{array}{c}\text { Economic } \\
\text { Value } \\
\text { Upper } 20 \\
\text { Percentile } \\
\quad(\$)\end{array}$ & $\begin{array}{c}\text { Share EV } \\
\text { Value in \% } \\
\text { Lower }\end{array}$ & $\begin{array}{c}\text { Share EV } \\
\text { Value in \% } \\
\text { Higher }\end{array}$ \\
\hline Motorcycle & 0.0002 & 0.02 & 0 & 2.3 & 100 & 120 & 14 & 17 \\
\hline Rickshaw & 0.0015 & 0.05 & 0 & 8.9 & 390 & 510 & 11 & 14 \\
\hline Passenger car & 0.0002 & 0.01 & 0 & 14 & 570 & 590 & 2 & 2 \\
\hline Taxi & 0.0126 & 0.23 & 0.002 & 51 & 2,310 & 3,240 & 8 & 11 \\
\hline Urban standard bus & 0.0450 & 5.28 & 0.029 & 431 & 18,790 & 24,440 & 8 & 10 \\
\hline $\begin{array}{l}\text { Urban truck } \\
\text { 3.5-7-ton }\end{array}$ & 0.00636 & 0.98 & 0.006 & 125 & 5,230 & 6,160 & 10 & 12 \\
\hline
\end{tabular}

$\mathrm{EV}=$ electric vehicle, $\mathrm{GHG}$ = greenhouse gas, $\mathrm{NO}_{\mathrm{x}}=$ oxides of nitrogen, $\mathrm{PM}_{2.5}=$ particulate matter with a diameter of less than 2.5 micrometers, $\mathrm{SO}_{2}=$ sulfur dioxide.

\section{Armenia}

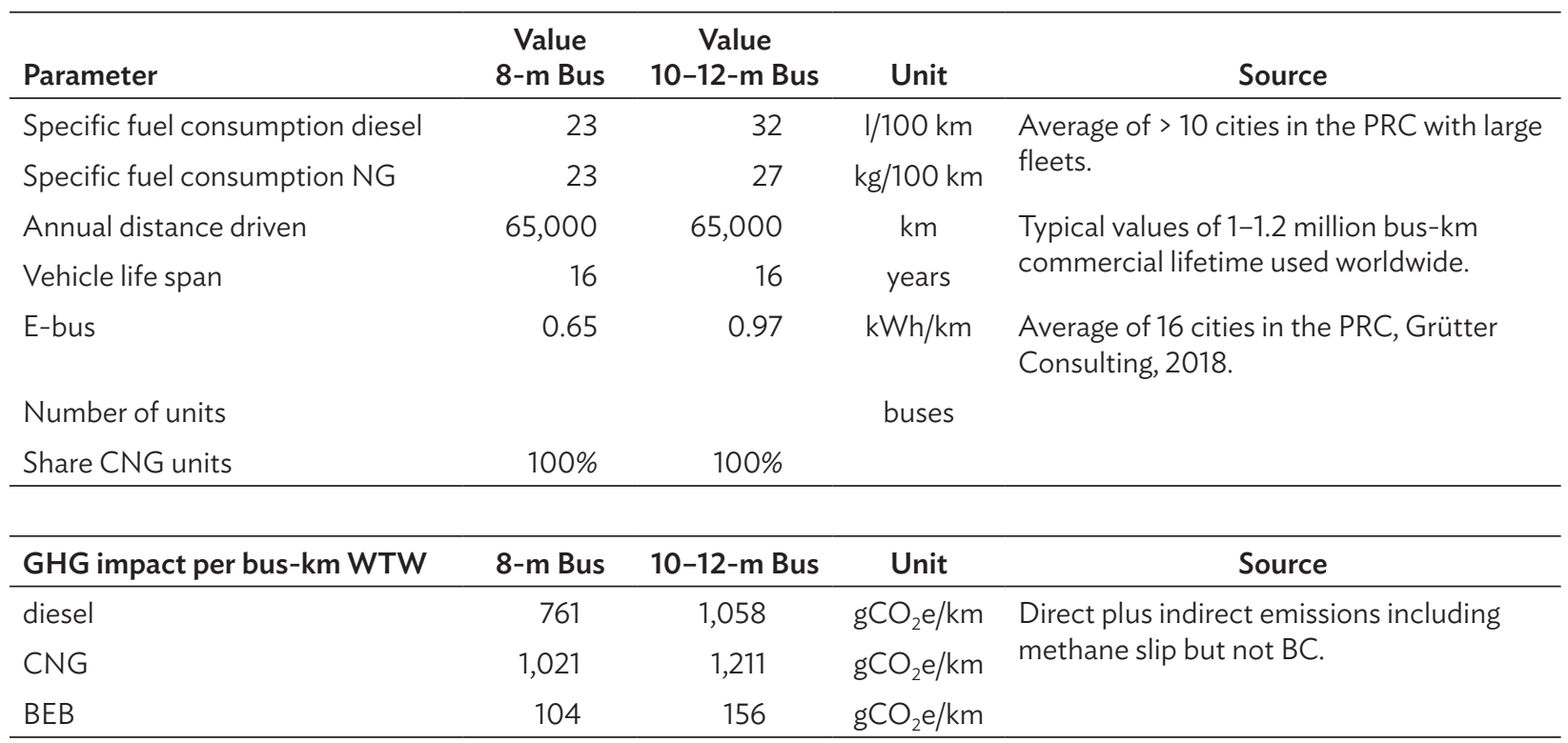

$\mathrm{BC}=$ black carbon, COPERT = Computer Program to calculate Emissions from Road Transport, $\mathrm{gCO}_{2} \mathrm{e} / \mathrm{km}=$ grams of carbon dioxide equivalent per kilometer, $\mathrm{GHG}=$ greenhouse gas, $\mathrm{kg} / 100 \mathrm{~km}=$ kilogram per 100 kilometers, $\mathrm{km}=$ kilometer, $\mathrm{kWh} / \mathrm{km}=\mathrm{kilowatt}$ hour per kilometer, $1 / 100 \mathrm{~km}$ = liter per 100 kilometers, PRC = People's Republic of China, WTW = wheel-to-wheel. 


\section{Dhaka}

\begin{tabular}{|c|c|c|c|}
\hline Parameter & Value & Unit & Source \\
\hline Specific fuel consumption CNG rickshaws & 6.3 & $\mathrm{~m}^{3} / 100 \mathrm{~km}$ & Based on data rickshaws in Dhaka, 2016. \\
\hline Annual million vehicle-km CNG rickshaws & 1,595 & million vkm & $\begin{array}{l}\text { For year 2014; based on urban NAMA Dhaka, } \\
\text { Grütter Consulting based on trip numbers } \\
\text { hosuehold survey, trip distances, motorized } \\
\text { rickshaw user share, and average occupation rate } \\
\text { of rickshaws. }\end{array}$ \\
\hline TTW GHG emissions CNG rickshaws & 213,536 & $\mathrm{tCO}_{2} \mathrm{e}$ & \\
\hline WTW GHG emissions CNG rickshaws & 315,772 & $\mathrm{tCO}_{2} \mathrm{e}$ & \\
\hline Grid factor Bangladesh & 0.64 & $\mathrm{kgCO}_{2} / \mathrm{kWh}$ & \\
\hline Electricity usage e-rickshaw & 0.13 & $\mathrm{kWh} / \mathrm{km}$ & \\
\hline WTW GHG emissions electric rickshaws & 132,298 & $\mathrm{tCO}_{2} \mathrm{e}$ & \\
\hline Daily distance driven rickshaws & 100 & $\mathrm{~km}$ & Survey Dhaka, 2018. \\
\hline Estimated number of rickshaws & 48,322 & rickshaws & From vkm and daily distance driven. \\
\hline
\end{tabular}

$\mathrm{BC}$ = black carbon, $\mathrm{CNG}=$ compressed natural gas, $\mathrm{COPERT}=$ Computer Program to calculate Emissions from Road Transport, $\mathrm{GHG}=$ greenhouse gas, $\mathrm{kg} / 100 \mathrm{~km}=$ kilogram per 100 kilometers, $\mathrm{kgCO}_{2} / \mathrm{kWh}=$ kilograms of carbon dioxide per kilowatt hour, $\mathrm{km}=$ kilometer, $\mathrm{kWh} / \mathrm{km}=$ kilowatt hour per kilometer, $\mathrm{m}^{3} / 100 \mathrm{~km}=$ cubic meters per 100 kilometers, $\mathrm{tCO}_{2}=$ tons of carbon dioxide, $\mathrm{vkm}=$ vehicle kilometer

\section{Georgia}

\begin{tabular}{|c|c|c|c|c|}
\hline Parameter & $\begin{array}{l}\text { Value } \\
\text { 8-m Bus }\end{array}$ & $\begin{array}{l}\text { Value } \\
10-m \text { Bus }\end{array}$ & Unit & Source \\
\hline Specific fuel consumption diesel & 23 & 32 & $\mathrm{l} / 100 \mathrm{~km}$ & \multirow[t]{2}{*}{ Average of $>10$ cities in the PRC with large fleets. } \\
\hline Specific fuel consumption NG & 23 & 28 & $\mathrm{~kg} / 100 \mathrm{~km}$ & \\
\hline Annual distance driven & 65,000 & 65,000 & $\mathrm{~km}$ & \multirow{2}{*}{$\begin{array}{l}\text { Typical values of 1-1.2 million bus-km commercial } \\
\text { lifetime used worldwide. }\end{array}$} \\
\hline Vehicle life span & 16 & 16 & years & \\
\hline E-bus & 0.65 & 0.8 & $\mathrm{kWh} / \mathrm{km}$ & $\begin{array}{l}\text { Average of } 16 \text { cities in the PRC, Grütter } \\
\text { Consulting, } 2018 .\end{array}$ \\
\hline Number of units & 400 & 400 & buses & Tbilisi estimate. \\
\hline Share CNG units & $0 \%$ & $100 \%$ & & Tbilisi estimate. \\
\hline
\end{tabular}

\begin{tabular}{lrrcl}
\hline GHG impact per bus-km WTW & 8- $\mathrm{m}$ Bus & 10- $\mathrm{m}$ Bus & Unit & \multicolumn{1}{c}{ Source } \\
\hline Diesel & 761 & 1,058 & $\mathrm{gCO}_{2} \mathrm{e} / \mathrm{km}$ & Direct plus indirect emissions including methane \\
CNG & 1,021 & 1,243 & $\mathrm{gCO}_{2} \mathrm{e} / \mathrm{km}$ & slip but not BC. \\
BEB & 83 & 103 & $\mathrm{gCO}_{2} \mathrm{e} / \mathrm{km}$ & \\
\hline
\end{tabular}

\section{Purchase BEBs instead of fossil buses}

\begin{tabular}{lrl}
\hline GHG impact per annum & 47,244 & $\mathrm{tCO}_{2}$ \\
GHG impact life span & 755,896 & $\mathrm{tCO}_{2}$ \\
\hline
\end{tabular}

$\mathrm{BC}=$ black carbon, $\mathrm{BEB}=$ battery electric bus, $\mathrm{gCO}_{2} \mathrm{e} / \mathrm{km}=$ grams of carbon dioxide equivalent per kilometer, $\mathrm{GHG}=$ greenhouse gas, $\mathrm{kg} / 100 \mathrm{~km}=$ kilogram per 100 kilometers, $\mathrm{km}=$ kilometer, $\mathrm{kWh} / \mathrm{km}=$ kilowatt hour per kilometer, $\mathrm{I} / 100 \mathrm{~km}=$ liter per $100 \mathrm{kilometers,}$ $\mathrm{PRC}=$ People's Republic of China, $\mathrm{tCO}_{2}=$ tons of carbon dioxide. 


\section{Ha Noi Motorcycles}

\begin{tabular}{lrrl}
\hline Parameter & \multicolumn{1}{c}{ Value } & Unit & Source \\
\hline Gasoline fuel consumption & 2.5 & $\mathrm{l} / 100 \mathrm{~km}$ & $110 \mathrm{cc}$ motorbike; World Bank 2014b. \\
Electricity consumption & 0.04 & $\mathrm{kWh} / \mathrm{km}$ & \\
Annual mileage & 4,100 & $\mathrm{~km}$ & World Bank,survey 2014. \\
Number of motorcycles in city & $4,600,000$ & & World Bank survey 2014; metropolitan area. \\
Share e-bikes current & $16 \%$ & & World Bank survey 2014. \\
\hline
\end{tabular}

\begin{tabular}{lrr}
\hline GHG Impact & Gasoline & Electric \\
\hline GHG emissions WTW tons per unit per annum & 0.28 & 0.09 \\
GHG emissions WTW fleet based on current composition & $1,072,169$ & 63,761 \\
Potential GHG savings 100\% electric (current share 20\%) & & 737,422 \\
\hline
\end{tabular}

$\mathrm{GHG}=$ greenhouse gas, $\mathrm{km}=$ kilometer, $\mathrm{kWh} / \mathrm{km}=$ kilowatt hour per kilometer, $\mathrm{l} / 100 \mathrm{~km}=$ liter per 100 kilometers, $\mathrm{tCO}_{2}=$ tons of carbon dioxide, WTW = wheel-to-wheel.

\section{Nepal}

Greenhouse Gas Impact Electric Safas

\begin{tabular}{lrcc}
\hline Parameter & Value & Unit & Source \\
\hline Passenger capacity diesel microbus & 16 & passengers & Bhatta, 2004, Table 5.1.1. based on surveys. \\
Passenger capacity e-Safas & 12 & passengers & \\
Annual distance e-Safas & 18,000 & $\mathrm{~km}$ & \\
Electricity consumption e-Safas & 0.267 & $\mathrm{kWh} / \mathrm{km}$ & \\
Diesel consumption microbus & 10 & $\mathrm{l} / 100 \mathrm{~km}$ & \\
Number of e-Safas & 600 & vehicles & As of early 2000. Bhatta, 2004. \\
Grid factor Nepal & 0 & $\mathrm{kgCO}_{2} / \mathrm{kWh}$ & \\
\hline
\end{tabular}

$\mathrm{kgCO}_{2} / \mathrm{km}=$ kilograms of carbon dioxide e per kilometer, $\mathrm{km}=$ kilometer, $\mathrm{kWh} / \mathrm{km}=$ kilowatt hour per kilometer, $\mathrm{l} / 100 \mathrm{~km}=$ liter per 100 kilometers.

\section{Singapore Car Sharing}

\begin{tabular}{|c|c|c|c|}
\hline Parameter & Value & Unit & Source \\
\hline Gasoline SFC used in car sharing & 5 & $\mathrm{l} / 100 \mathrm{~km}$ & $\begin{array}{l}\text { Based on Nissan Note used by CarClub with fuel usage } \\
\text { based on https://www.honestjohn.co.uk/realmpg/ } \\
\text { nissan/note-2013. }\end{array}$ \\
\hline Annual mileage BlueSG & 23,000 & $\mathrm{~km}$ & Based on BlueSG mileage first 2 months. \\
\hline GHG grid factor Singapore & 0.42 & $\mathrm{kgCO}_{2} / \mathrm{kWh}$ & EMA used by LTA. 2016. \\
\hline Target fleet & 1,000 & vehicles & BlueSG. \\
\hline Annual GHG reduction per car & 1.5 & $\mathrm{tCO}_{2}$ & WTW. \\
\hline Annual GHG reduction target fleet & 1,471 & $\mathrm{tCO}_{2}$ & \\
\hline
\end{tabular}

$\mathrm{kgCO}_{2} / \mathrm{km}=$ kilograms of carbon dioxide e per kilometer, $\mathrm{km}=$ kilometer, $\mathrm{l} / 100 \mathrm{~km}=$ liter per 100 kilometers, $\mathrm{tCO}_{2}=$ tons of carbon dioxide, WTW = wheel-to-wheel. 
Udaipur

\begin{tabular}{|c|c|c|c|}
\hline Parameter & Value & Unit & Source \\
\hline Grid factor & 0.82 & $\mathrm{kgCO}_{2} / \mathrm{kWh}$ & CEA, 2017. \\
\hline Rickshaw diesel usage & 2.25 & $\mathrm{l} / 100 \mathrm{~km}$ & \multirow{5}{*}{$\begin{array}{l}\text { Capacities, 2018, Table 13; average loader anc } \\
\text { small auto rickshaw. }\end{array}$} \\
\hline Rickshaw electricity usage & 8 & $\mathrm{kWh} / 100 \mathrm{~km}$ & \\
\hline Electricity tariff & 0.1 & $\$ / \mathrm{kWh}$ & \\
\hline CAPEX diesel & 3,400 & $\$$ & \\
\hline CAPEX Li-ion & 3,500 & $\$$ & \\
\hline Maintenance cost per annum diesel & 65 & $\$$ & Capacities, 2018, Table 13 (\% of electric). \\
\hline Maintenance cost per annum electric & 130 & $\$$ & Capacities, 2018, Table 11. \\
\hline Annual mileage & 16,000 & $\mathrm{~km}$ & Capacities Tables 5 and 13 calculated. \\
\hline Battery charger cost & 150 & $\$$ & Capacities, 2018, Table 5. \\
\hline Battery life & 2 & years & \\
\hline CAPEX battery & 1,290 & $\$$ & Including recycling cost. \\
\hline Government Subsidy & 650 & $\$$ & \\
\hline Number of rickshaws & 6,000 & & Based on share of small rickshaws. \\
\hline Lifetime & 6 & years & Assumption. \\
\hline
\end{tabular}

CAPEX = capital expenditure, $\mathrm{CEA}=$ Central Electricity Authority, $\mathrm{kgCO}_{2} / \mathrm{km}=$ kilograms of carbon dioxide e per kilometer, $\$ / \mathrm{kWh}=$ dollar per kilowatt hour, $\mathrm{kWh} / 100 \mathrm{~km}=$ kilowatt hour per 100 kilometers, $1 / 100 \mathrm{~km}=$ liter per 100 kilometers.

\section{Udaipur Rickshaws}

\begin{tabular}{|c|c|c|c|c|}
\hline Parameter & Fossil TTW & Fossil WTW & EV TTW & EV WTW \\
\hline GHG emissions per annum in tons & 0.97 & 1.19 & 0 & 1.05 \\
\hline GHG emissions lifetime in tons & 5.8 & 7.1 & 0.0 & 6.3 \\
\hline GHG reduction fleet per annum in tons & & & 5,809 & 847 \\
\hline CAPEX including charger and battery replacement & 3,400 & & 4,940 & \\
\hline OPEX annual & 436 & & 258 & \\
\hline TCO per km non-discounted & 0.063 & & 0.068 & \\
\hline TCO per km non-discounted with subsidy & 0.063 & & 0.061 & \\
\hline
\end{tabular}

$\mathrm{CAPEX}=$ capital expenditure, $\mathrm{EV}=$ electric vehicle, $\mathrm{GHG}=$ greenhouse gas, $\mathrm{OPEX}=$ operating expenses, $\mathrm{TCO}=$ total cost of ownership, TTW = tank-to-wheel, WTW = wheel-to-wheel. 


\section{REFERENCES}

ADB. 2018. Sustainable Transport Solutions: Low-Carbon Buses in the People's Republic of China. Manila.

2017. Promoting Sustainable Transport Through Improving Nonmotorized Transport. Paris.

2013. Catalytic Demonstration of Pro-Poor Accessibility. Manila.

BAFU. 2009. PM-10 Emissionsfaktoren von Abriebspartikeln des Strassenverkehrs (APART). Bern.

Bhatta, S. D. and D. R. Joshi. 2014. Are Electric Vehicles Viable in Kathmandu? A Cost-Benefit Perspective. Washington, DC.

Bloomberg New Energy Finance. 2018. Electric Buses in Cities.

Bond et al. 2013. Bounding the Role of Black Carbon in the Climate System: A Scientific Assessment. Journal of Geophysical Research. doi:10.1002/jgrd.50171.

Boston Consulting Group. 2018. PR China Mobility Market Overview.

Capacities. 2018a. E-Rickshaw Pilot Assessment for Udaipur, Rajasthan.

. 2018b. Assessment of E-Rickshaw Operations in Delhi.

CARB. 2015. EMFAC2014 Volume III - Technical Documentation.

CHIC. 2016. London Hydrogen Buses and the CHIC Project.

Clougherty, J. 2010. A Growing Role for Gender Analysis in Air Pollution Epidemiology. Environmental Health Perspectives. February 2010. 118(2). 167-176.

EEA. 2016a. Air Pollutant Emission Inventory Guidebook Version 2016 Update. December 2016.

-2016b. Road Vehicle Tyre and Brake Wear.

EPA. 2016. Light-Duty Automotive Technology, Carbon Dioxide Emissions, and Fuel Economy Trends: 1975 Through 2016.

European Climate Foundation. 2018. Low-Carbon Cars in Europe: A Socio-Economic Assessment.

Faltenbacher, M. et al. 2011. Abschlussbericht Plattform Innovative Antriebe Bus. Auftraggeber Bundesministerium für Verkehr, Bau und Stadtentwicklung.

Gee, D. L. T. 2015. Implementation of Green Technology Policy in Malaysia.

Government of India. 2013. National Electric Mobility Mission Plan 2020.

Grieshop, A. et al. 2012. Modelling Air Pollutant Emissions from Indian Auto-Rickshaws: Model Development and Implications for Fleet Emission Rate Estimates. Atmospheric Environment 50. 148-156. 
Grütter Consulting. 2018a. Low Carbon Buses in PRC.

.2018b. GHG and Air Quality Impact of the BRT Karachi and Assessment of Technology Options for BRT Buses.

. 2018c. Land Transport Sector for LEDS Fiji.

2016a. GHG Transport Inventory and Mitigation Options Udaipur.

2016b. NAMA Urban Passenger Transport Dhaka, Bangladesh.

2015. CALAC Evaluation Report.

Harrison, P. 2018. Fuelling Europe's Future: How the Transition from Oil Strengthens the Economy.

2017. Low-Carbon Cars in Germany: A Socio-Economic Assessment.

ICCT. 2018a. Effects of Battery Manufacturing on Electric Vehicle Life Cycle Greenhouse Gas Emissions.

2018b. Power Play: How Governments Are Spurring the Electric Vehicle Industry.

2018c. Assessment of New Energy Passenger Vehicle Incentives in Cities in Chinese Cities.

2018d. PR China's New Energy Vehicle Mandate Policy (Final Rule).

- 2017a. The Rise of Electric Vehicles: The Second Million. https://www.theicct.org/blogs/staff/ second-million-electric-vehicles.

2017b. Electric Vehicle Capitals of the World: What Markets Are Leading the Transition to Electric. Briefing. November 2017.

-2017c. Transitioning to Zero-Emission Heavy-Duty Freight Vehicles.

_.2017d. Emerging Best Practices for Electric Vehicle Charging Infrastructure.

_2016. Assessment of Next-Generation Electric Vehicle Technologies.

. 2015. Assessment of Heavy Duty Natural Gas Vehicles Emissions: Implications and Policy Recommendations.

2014. Driving Electrification: A Global Comparison of Fiscal Incentive Policy for Electric Vehicles.

IEA. 2018a. Nordic EV Outlook 2018. Paris.

2018b. Global EV Outlook 2018. Paris.

2017a. Energy Technology Perspective 2017 - Catalysing Energy Technology Transformations. Paris.

. 2017b. Global EV Outlook 2017. Paris. 
-2017c. CO Emissions from Fuel Combustion. Paris.

. 2015. Energy Technology Perspectives 2015 - Mobilizing Innovation to Accelerate Climate Action. Paris.

IMF. 2014. Getting Energy Prices Right. Washington, DC.

Innovation Norway. 2017. India EV Story.

Interface. 2006. Evaluation Car-Sharing. Bern.

IPCC. 2006. IPCC Guidelines for National Greenhouse Gas Inventories.

lyer, N. 2012. A Technical Assessment of Emissions and Fuel Consumption Reduction Potential from Tow and Three Wheelers in India. Washington, DC.

Lajunen, A. 2012. Evaluation of Battery Requirements for Hybrid and Electric City Buses. World Electric Vehicle Journal. Vol. 5-ISSN 2032-665.

Lean Energy Nepal CEN. Undated. Electric Vehicles in Kathmandu.

Lin, B. M. 2018. ADB presentation, 30 January 2018.

Maharja, S. 2002. Electric Vehicle Technology in Kathmandu, Nepal: A Closer Look at Its Development.

McKinsey. 2018a. The Global Electric-Vehicle Market Is Amped Up and on the Rise.

_. 2018b. Three Surprising Resource Implications from the Rise of Electric Vehicles.

-2017a. Electrifying Insights: How Automakers Can Drive Electrified Vehicle Sales and Profitability.

2017b. What's Sparking Electric-Vehicle Adoption in the Truck Industry?

. 2017c. The Future of Mobility in India: Challenges \& Opportunities for the Auto Component Industry.

.2017d. Dynamics in the Global Electric-Vehicle Market.

2016. Finding the Fast Lane: Emerging Trends in PR China's Auto Market.

Ministry of Economy of Fiji. 2018. Fiji LEDS.

Mitchell, G. and D. Dorling. 2003. An Environmental Justice Analysis of British Air Quality. Environment and Planning A. Vol. 35. 909-929.

MJB\&A. 2012. Clean Diesel versus CNG Buses: Cost, Air Quality, \& Climate Impacts.

National Grid. 2017. Future Energy Scenarios. 
NREL. 2017. Foothill Transit Battery Electric Bus Demonstration Results: Second Report. NREL/TP-540067698.

OIES. 2018. Disruptive Change in the Transport Sector: Eight Key Takeaways. Oxford.

PSI. 2016. Trends und Potenziale der Brennstoffzellen-Entwicklung.

TRL. 2014. Briefing Paper on Non-Exhaust Pemissions from Road Transport.

UBA. 2016. Weiterentwicklung und vertiefte Analyse der Umweltbilanz von Elektrofahrzeugen, Texte 27/2016. Dessau-Rosslau.

UBS. 2017. UBS Evidence Lab Electric Car Teardown - Disruption Ahead?

UITP. 2017. An Electric Solution for Urban Bus Networks. Presentation by P. Bruge, Berlin, 21 September 2017.

UNECE. 2015. Transport for Sustainable Development.

UNFCCC. 2014. CDM Methodological Tool: Upstream Leakage Emissions Associated with Fossil Fuel Usage, Version 02.0. Bonn.

Vincentric. 2014. Vincentric Hybrid Analysis.

World Bank. 2014a. Reducing Black Carbon Emissions from Diesel Vehicles: Impacts, Control Strategies, and Cost-Benefit Analysis. Washington, DC.

-2014b. Motorcycle, Motor Scooter and Motorbike Ownership \& Use in Hanoi. Washington, DC.

Yang, C. J. 2010. Launching Strategy for Electric Vehicles. Technological Forecasting and Social Change 77. 831-834.

Yongpisanphob, W. 2017. Thailand and the Development of Electric Vehicles. 


\section{E-Mobility Options for ADB Developing Member Countries}

This working paper presents an analysis of options for the development and deployment of e-mobility solutions in developing Asian countries. The growing motorization of Asia will not only increase traffic congestion, but it will also increase greenhouse gas emissions. Solving this challenge will require moving away from the combustion engine and toward electric and hybrid vehicles. Recommendations in this paper focus on actions that can be taken to support this evolution of the Asian transport sector.

\section{About the Asian Development Bank}

ADB is committed to achieving a prosperous, inclusive, resilient, and sustainable Asia and the Pacific, while sustaining its efforts to eradicate extreme poverty. Established in 1966, it is owned by 68 members -49 from the region. Its main instruments for helping its developing member countries are policy dialogue, loans, equity investments, guarantees, grants, and technical assistance.

\section{ר) $\mathrm{EAKPF}$}

